INSTITUTO DE PESQUISAS ENERGÉTICAS E NUCLEARES AUTARQUIA ASSOCIADA À UNIVERSIDADE DE SÃO PAULO

\title{
CARACTERIZAÇÃO E DESEMPENHO DE UM FILME DE CARBONO AMORFO HIDROGENADO TIPO DIAMANTE (a-C:H) DOPADO COM SILÍCIO, APLICADO EM CAMISA DE CILINDRO DE MOTOR À COMBUSTÃO INTERNA
}

Dissertação apresentada como parte dos requisitos para obtenção do Grau de Mestre em Ciências na Área de Tecnologia Nuclear - Materiais.

Orientadora:

Dra. Marina Fuser Pillis 


\section{AGRADECIMENTOS}

A minha esposa Daniela e a minha filha Lívia pela paciência e o amor demostrados ao longo da duração deste mestrado.

A minha orientadora, Dra. Marina Fuser Pillis, pela confiança depositada e pela sua capacidade de me mostrar maneiras simples e objetivas de expressar as minhas ideias, além da sua colaboração efetiva para o bom andamento deste trabalho.

Ao meu colega Dr. Eduardo Tomanik, que me auxiliou durante a evolução deste trabalho sempre buscando me orientar na forma mais correta de interpretar e apresentar os resultados.

Ao meu colega Paulo Mordente, pelo seu total apoio e dedicação nos trabalhos executados na preparação dos protótipos e na execução dos ensaios experimentais, assim como um fundamental alicerce no conhecimento do processo de deposição de filme DLC pela técnica PACVD.

A empresa MAHLE Metal Leve S.A. pelo apoio profissional, permitindo assim a minha dedicação para concluir este trabalho.

Ao Dr. Carlos Figueiroa, do Instituto Nacional de Engenharia de Superfícies, vinculado a Universidade de Caxias do Sul (UCS), pelos ensaios de nanoindentação.

Ao Professor Evaldo José Corat, do Instituto Nacional de Pesquisas Espaciais (INPE), pelo suporte prestado nas análises de Raman. 
Há homens que lutam um dia e são bons. Há outros que lutam um ano e são melhores.

Há os que lutam muitos anos e são muito bons.

Porém, há os que lutam toda a vida. Esses são os imprescindíveis.

Bertolt Brecht. 


\section{RESUMO}

Nas últimas décadas, questões sobre o controle de emissões em motores à combustão interna e sobre a redução de consumo de combustível vêm sendo debatidas globalmente, com claros desdobramentos em especificações de controles mais restritos, a fim de permitir a comercialização de novos motores à combustão interna a consumidores mais exigentes, que presam pela qualidade de vida e meio ambiente. Mesmo com a introdução de novas tecnologias, os motores ainda apresentam uma grande perda da energia gerada por conta do atrito mecânico. Com base neste contexto, os projetos dos novos motores visam uma melhor eficiência térmica e mecânica, com auxílio de soluções de engenharia que possam beneficiar o desempenho dos motores, resultando em uma melhor queima do combustível e menor atrito. Um dos contribuintes mais relevantes para o atrito num motor é o sistema pistão-anel de pistão-camisa de cilindro que é o foco de muitos trabalhos em busca da redução das perdas por atrito. As propriedades dos filmes à base de carbono tipo diamante ("Diamond-Like Carbon" - DLC) são bem conhecidas por apresentam alta resistência ao desgaste e baixo coeficiente de atrito, tornando-se adequados para diferentes aplicações tribológicas. O presente trabalho discute a viabilidade técnica de se aplicar um filme DLC amorfo hidrogenado, com gradiente de composição química, sobre a superfície interna brunida de camisas de cilindro para redução do atrito. A metodologia aborda duas espessuras de filme: 2,5 e 12,5 $\mu \mathrm{m}$, depositadas pelo processo de deposição química em fase vapor assistida por plasma (PACVD), como alternativa para redução do atrito do motor e, consequentemente, redução no consumo específico de combustível, e ainda na redução do desgaste dos anéis de pistão e da superfície de trabalho da camisa de cilindro. Comparando camisas de cilindro com mesma rugosidade na superfície interna, denominadas camisas de referência (sem revestimento interno) e camisas recobertas com filme DLC, testes de bancada com movimento recíproco de contato mostraram redução do coeficiente de atrito (COF) em até 19\%. Testes de motor ciclo Otto e Diesel em banco de prova com dinamômetro conferiram, respectivamente, uma redução da pressão média efetiva de atrito (FMEP) do motor em até $12 \%$ e consumo específico de combustível (BSFC) em até 2,5\% em rotações de 1000 a 1400 rpm. 


\begin{abstract}
In the last few decades questions about emissions level control for internal combustion engines as well as fuel consumption reduction have been debated in a global bases with clear deployments in more restricted control specifications to allow the commercialization of new internal combustion engines to more restrictive markets that look for a better life quality and environment. Even with the introduction of new technologies the engines still present a significant loss of energy due to the mechanical friction. With base in this context, the new development projects seek for high mechanical-thermal efficiency linked with engineer that can benefit the engine performance with a better combustion process and reduced friction as well. One of the most relevant contributors for the friction in an engine is the piston-piston ring-cylinder liner system which has been the focus of many research works with focus on reduce engine friction losses. The properties of Diamond-Like Carbon films (DLC) are well-known such as superior wear resistance and low friction coefficients that makes suitable for many different tribology applications. This work evaluates the application of a graded hydrogen amorphous DLC film with applied over cylinder liner running surface. The methodology approach two coating thickness: 2.5 and $12.5 \mu \mathrm{m}$, deposited by the plasma assisted chemical vapor deposition process (PACVD) as the alternative solution for engine friction reduction and thus a reduction on brake specific fuel consumption (BSFC), and a improved wear resistance behavior of the piston rings and cylinder liner contact surfaces as well. By using baseline parts without inner DLC coating and DLC coated parts with similar running roughness surfaces, comparative reciprocating bench tests showed a tendency of coefficient of friction (COF) reduction in up to $19 \%$. In a same trend, fired gasoline and diesel engine tests showed a friction mean effective pressure reduction (FMEP) in to $12 \%$ and small brake specific fuel consumption (BSFC) in up to $2.5 \%$ at low engine speed range respectively.
\end{abstract}




\section{SUMÁRIO}

Página

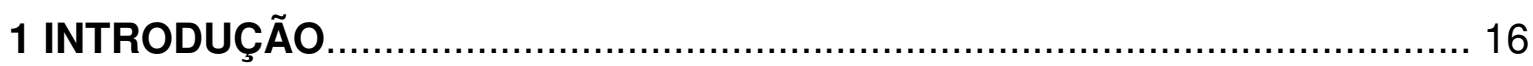

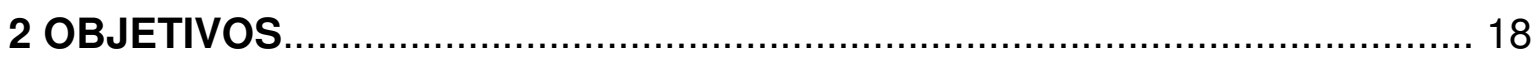

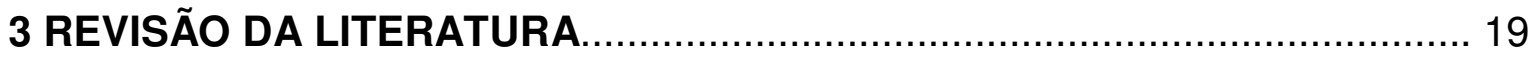

3.1 Perdas Mecânicas em motores à combustão interna................................... 19

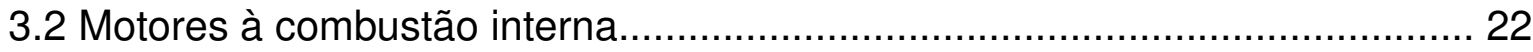

3.2.1 Motores de ignição por centelha...................................................... 22

3.2.2 Motores de ignição por compressão................................................... 22

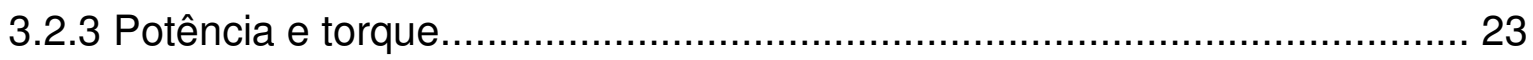

3.2.4 Eficiência mecânica....................................................................... 24

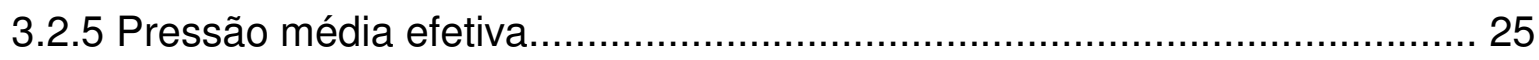

3.2.6 Consumo específico de combustível.................................................. 26

3.3 As novas leis de emissões para redução do consumo de combustível.......... 26

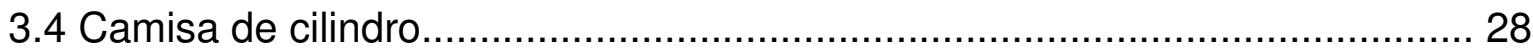

3.5 Anéis de pistão e sua interação com a camisa de cilindro.......................... 23

3.6 Materiais utilizados em camisas de cilindro.............................................. 34

3.7 Superfície de trabalho em uma camisa de cilindro................................... 35

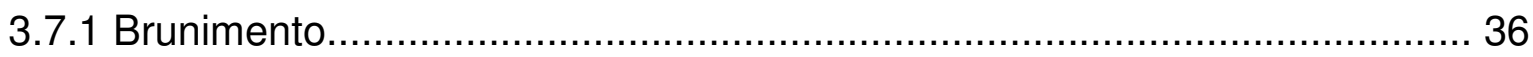

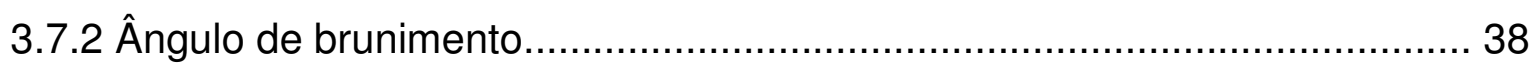

3.7.3 Técnicas de medição e parâmetros de controle em superfícies brunidas... 39

3.7.4 Tipos de brunimento........................................................................... 46

3.8 Atrito gerado pelo contato dos anéis de pistão na camisa de cilindro ........... 52

3.8.1 A influência do brunimento na redução do atrito do motor........................ 53

3.9 Mecanismos de desgaste em camisas de cilindro................................... 53

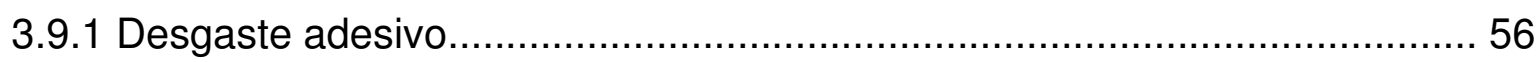

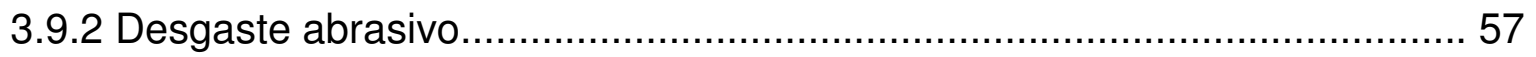

3.10 Medição do desgaste em camisas após teste de rodagem........................ 59

3.11 Engenharia de superfície em componentes de motor................................60

3.12 Filmes à base de carbono tipo diamante - DLC..................................61

3.12.1 Incorporação de átomos de Si em filmes de carbono amorfo....................65

3.12.2 Propriedades mecânicas dos filmes DLC.......................................... 68

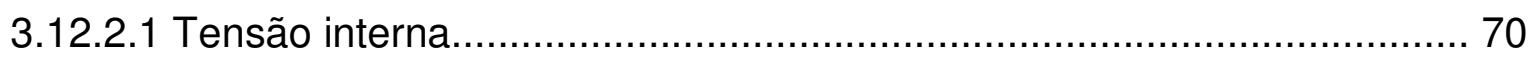

3.12.2.2 Nanoindentação em filmes DLC................................................. 71 
3.12.3 Módulo de elasticidade em filmes DLC................................................. 71

3.12.4 Propriedades tribológicas dos filmes DLC........................................... 73

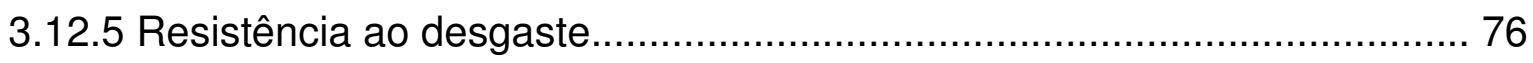

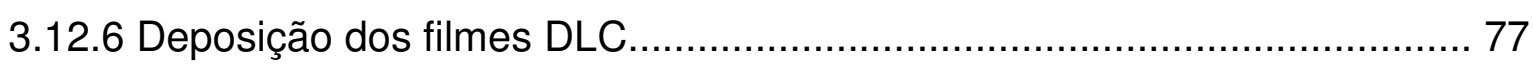

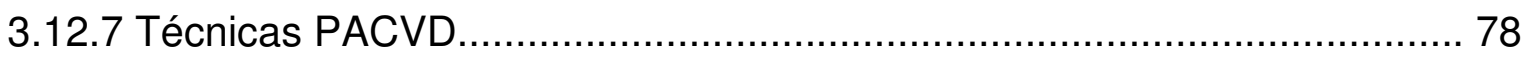

3.12.8 Espectroscopia de espalhamento Raman.............................................. 79

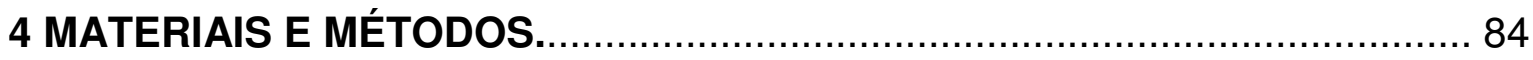

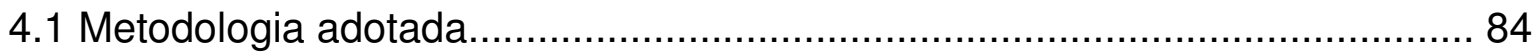

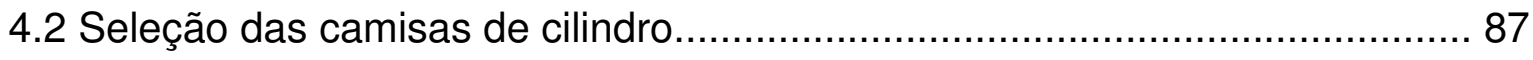

4.3 Processo de deposição e características do filme DLC................................ 89

4.4 Controle dimensional das camisas antes e após deposição do DLC.............. 91

4.5 Caracterização microestrutural do filme DLC.............................................. 92

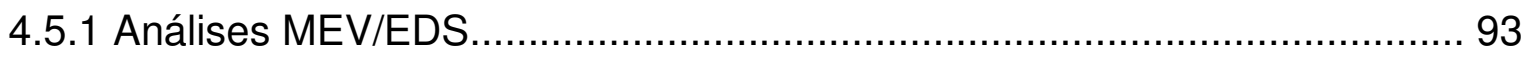

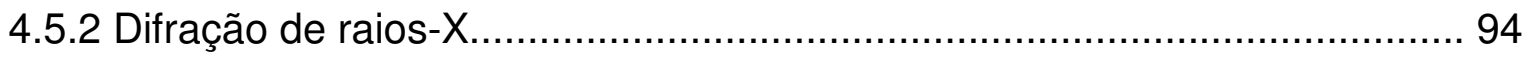

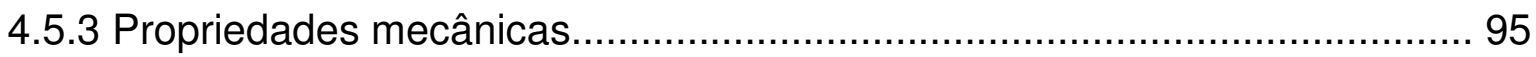

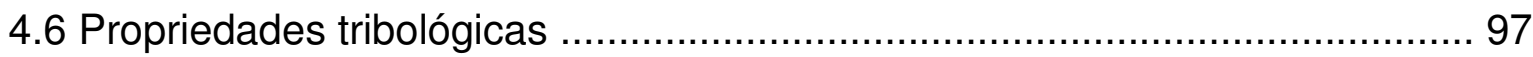

4.6.1 Aquisição de dados e apresentação dos resultados do COF.................... 100

4.7 Testes de motor ciclo Otto à gasolina para medir a força de atrito................ 101

4.8 Teste de motor ciclo Diesel................................................................... 104

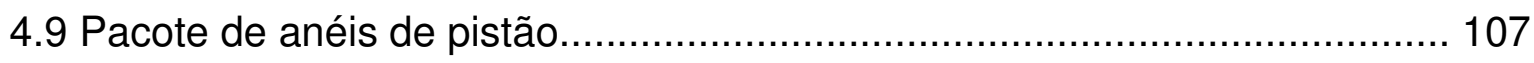

4.10 Espectroscopia de espalhamento Raman............................................. 108

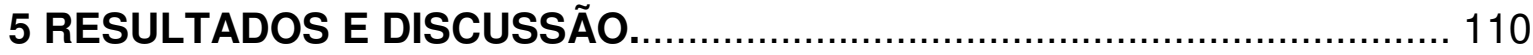

5.1 Primeira fase - Desenvolvimento do conceito........................................... 110

5.1.1 Verificação da integridade dimensional das camisas com filme DLC........ 110

5.1.2 Medição da rugosidade da superfície interna......................................... 119

5.1.3 Análise microestrutural do filme DLC................................................... 123

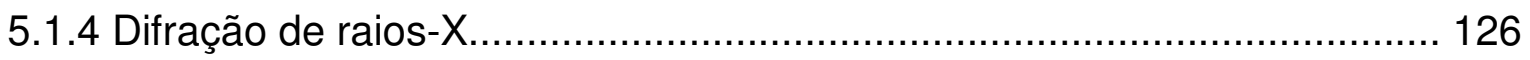

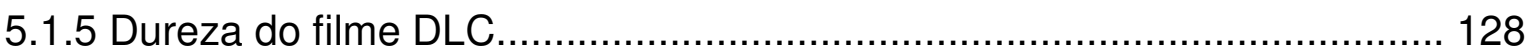

5.1.6 Coeficiente de atrito (COF) em bancada de teste recíproco de contato.... 129

5.1.7 Durabilidade do filme DLC - Recomendação de espessura do DLC........ 133

5.2 Segunda fase - Validação do conceito................................................... 138

5.2.1 Força de atrito em motor ciclo Otto com camisa flutuante......................... 138

5.2.2 Teste de motor ciclo Diesel para medição do BSFC................................ 140 
5.2.3 Espectroscopia de espalhamento Raman no filme DLC após 125 h de rodagem em motor ciclo Diesel.................................................................... 143

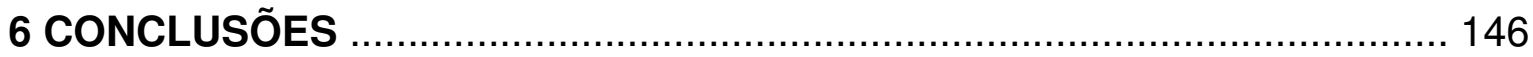

APÊNDICE A - Circularidade das camisas HD....................................... 148

APÊNDICE B - Parâmetros de brunimento medidos na camisa HD1 .......... 149

APÊNDICE C - Parâmetros de brunimento medidos na camisa HD2.......... 150

APÊNDICE D - Parâmetros de brunimento medidos na camisa HD4........... 151

APÊNDICE E - Parâmetros de brunimento medidos na camisa HD6.......... 152

APÊNDICE F - Resumos dos valores de COF a $\mathbf{1 2 0}^{\circ} \mathrm{C}$ (Oh) ....................... 153

APÊNDICE G - Resumos dos valores de COF a $120^{\circ} \mathrm{C}$ (2h)..................... 154

APÊNDICE H - Resumos dos valores de COF a $120^{\circ} \mathrm{C}$ (4h)....................... 155

APÊNDICE I - Propriedades físico-química do óleo SAE30........................ 156

REFERÊNCIAS BIBLIOGRÁFICAS........................................................ 157 


\section{LISTA DE TABELAS}

TABELA 1 - Características de materiais para camisas de cilindro...................... 34

TABELA 2 - Comparação entre os métodos de medição de rugosidade.............. 41

TABELA 3 - Definição dos parâmetros da série Rk.......................................... 46

TABELA 4 - Etapas de usinagem no brunimento e materiais abrasivos.............. 50

TABELA 5 - Resumo dos regimes de lubrificação.............................................. 53

TABELA 6 - Propriedades relacionadas ao desgaste do filme DLC.................... 64

TABELA 7 - Propriedades do diamante, carbono amorfo e grafite....................... 69

TABELA 8 - Propriedades Mecânicas do DLC................................................. 73

TABELA 9 - Relação de COF para filmes DLC............................................... 76

TABELA 10 - Principais técnicas de deposição/produção dos filmes DLC amorfo e algumas de suas características................................................................... 78

TABELA 11 - Parâmetros de brunimento das camisas de cilindro...................... 87

TABELA 12 - Relação das camisas HD...................................................... 88

TABELA 13 - Características do processo PACVD.......................................... 90

TABELA 14 - Parâmetros do teste de bancada recíproca.................................... 99

TABELA 15 - Dados do motor ciclo Otto à gasolina (FLE).............................. 103

TABELA 16 - Configuração de montagem do motor ciclo Diesel para teste de 500h - Fase de desenvolvimento do conceito................................................. 105

TABELA 17 - Ciclo de amaciamento padrão do motor ciclo Diesel.................... 105

TABELA 18 - Ciclo de durabilidade padrão do motor ciclo Diesel...................... 106

TABELA 19 - Especificação dos anéis para o motor ciclo Otto à gasolina

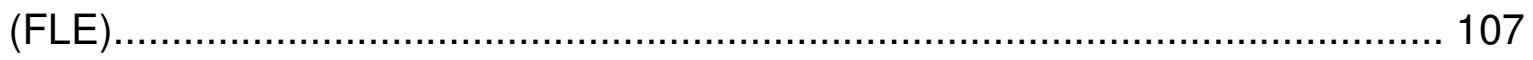

TABELA 20 - Jogos de anéis utilizados no motor ciclo Diesel.......................... 107

TABELA 21 - Diâmetro interno das camisas HD.......................................... 110

TABELA 22 - Circularidade das camisas HD em $\mu$ m..................................... 112

TABELA 23 - Retilineidade das camisas HD em $\mu$ m....................................... 115

TABELA 24 - Cilindricidade das camisas HD............................................. 117

TABELA 25 - Propriedades mecânicas do filme DLC...................................... 128

TABELA 26 - Resultados da análise dos espectros Raman............................. 145 


\section{LISTA DE FIGURAS}

FIGURA 1 - Distribuição da energia total utilizada e das perdas mecânicas em um motor ciclo Diesel.

FIGURA 2 - Distribuição da energia total e das perdas mecânicas em um motor ciclo Otto. 20

FIGURA 3 - Torque de atrito em função da rotação do motor ciclo Otto. 21

FIGURA 4 - Estimativa de economia de combustível vs. redução de atrito. 21

FIGURA 5 - Controle de emissão para veículos a Diesel nos Estados Unidos e na Europa de 1991 a 2011 27

FIGURA 6 - Limites de emissões para veículos a Diesel no Brasil.. 28

FIGURA 7 - Interação cilindro-pistão-anel no motor à combustão interna. 29

FIGURA 8 - (A) ilustração da camisa molhada, (B) ilustração da camisa seca... 30 FIGURA 9 - Principais termos utilizados para camisas de cilindro, onde (A) camisa molhada e (B) camisa seca.

FIGURA 10 - Gradiente térmico típico em camisas de cilindro gerado por simulação de elementos finitos em um motor ciclo Otto... 32

FIGURA 11 - Forças sobre um anel de pistão

FIGURA 12 - Ferro fundido cinzento lamelar. (A) Microestrutura sem ataque; (B) Microestrutura atacada.

FIGURA 13 - (A) Projeto de máquina de brunimento de Leonardo da Vinci em 1500; (B) Máquina de brunimento de cilindros desenvolvida pela empresa Gehring, modelo $1 Z$ de 1935. 36

FIGURA 14 - Detalhe da ferramenta de brunir momentos antes de iniciar a etapa de brunimento no bloco de motor.

FIGURA 15 - (A) Camisa de cilindro molhada após brunimento; (B) resultado da réplica da superfície brunida 38

FIGURA 16 - Perfil de superfície rugosa obtido por equipamento de medição... 39 FIGURA 17 - Detalhe "A" da FIG. 20 ilustrando a deformação quando se aplica a mesma ampliação nos eixos do gráfico do perfil. 40

FIGURA 18 - Perfil rugoso gerado por WLI. 40 FIGURA 19 - FIGURA 19 - Análise de superfície brunida (A) por MO e em (B) por MEV, onde (a) manchas na superfície e ranhuras interrompidas; (b) padrão das 
ranhuras; (c) porosidade ou partículas estranhas (d), material arrastado ou

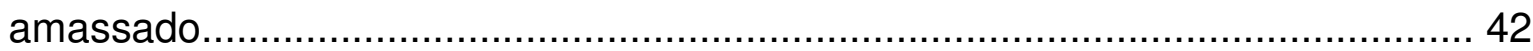

FIGURA 20 - Valores similares de Ra em superfícies rugosas diferentes.......... 43

FIGURA 21 - Parâmetros da série Rk.................................................... 44

FIGURA 22 - Tipos de brunimento em cilindros......................................... 47

FIGURA 23 - Brunimento por laser na região TDC.................................... 49

FIGURA 24 - Diagrama modificado de Stribeck mostrando os regimes, modo e forma de lubrificação para componentes de motor.

FIGURA 25 - Medição da rugosidade de diversos brunimentos. (A) Plateau honing (Rk 0,5-1,2 $\mu \mathrm{m})$; (B) Laser honing com bolsões de óleo (1 mm); (C) Slide honing (Rk 0,5-0,9 $\mu \mathrm{m})$; (D) Laser honing com bolsões de óleo (3 mm)............. 54 FIGURA 26 - Parâmetros da família Rk para diferentes superfícies usinadas... 55 FIGURA 27 - COF para diferentes superfícies.

FIGURA 28 - Formações de junções por adesão, onde (a) não há perda de material; (b) haverá subtração de material somente do corpo; (c) e (d) haverá desprendimento em ambos os corpos, segundo a área escura pintada..............5 57 FIGURA 29 - Mecanismos de desgaste envolvidos em desgaste abrasivo......... 58

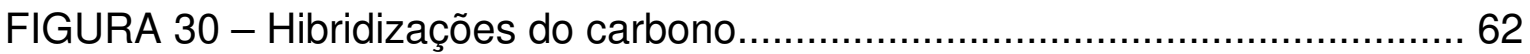
FIGURA 31 - Diagrama de fase ternário mostrando a estrutura de carbono amorfo hidrogenado 63

FIGURA 32 - Filmes DLC e suas designações. 65 FIGURA 33 - Taxa de deposição como função da polarização para duas concentrações diferentes de $\mathrm{SiH}_{4}$ na mistura gasosa: 0,2 e 2,0\% vol. 66 FIGURA 34 - (A) Dureza vs. concentração de $\mathrm{SiH}_{4}$, (B) Tensão interna vs. concentração de $\mathrm{SiH}_{4}$

FIGURA 35 - (A) Efeito da incorporação de Si (10\% at.) em filmes DLC em função da polarização e (B) comparação da dureza de filmes DLC com filmes Si-DLC em relação à concentração de Si.

FIGURA 36 - Variação do Módulo de Young com tensão de polarização para um a-C:H depositado do metano................................................................ 72

FIGURA 37 - Variação do Módulo de Young com a densidade .......................... 72 FIGURA 38 - Formação da camada de transferência. (a) material que se soltou de uma das superfícies; (b) material se aderindo a outra superfície. 74 FIGURA 39 - Esquema de reator PACVD assistido por micro-ondas 
FIGURA 40 - Influência das ligações $\mathrm{sp}^{3}$ no espectro Raman............................. 80

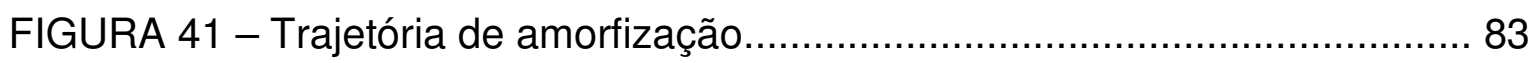

FIGURA 42 - Fluxo de atividades desenvolvidas na metodologia do trabalho.... 86

FIGURA 43 - Detalhe das camisas. (A) camisa HD, (B) camisa FL.................... 88

FIGURA 44 - Esquema do processo de deposição HCPIIP.............................. 89

FIGURA 45 - Morfologia do filme DLC, esquematicamente................................ 90

FIGURA 46 - Camisa HD com filme DLC na superfície interna.......................... 91

FIGURA 47 - Medição do diâmetro interno das camisas de cilindro.................... 93

FIGURA 48 - Localização dos corpos-de-prova para análise de MEV................. 94

FIGURA 49 - Desenho esquemático de uma seção em dois momentos de uma indentação

FIGURA 50 - Ciclo completo de carga e descarga de teste de nanoindentação. 96 FIGURA 51 - Tribômetro modelo CETR UMT-2 ………………………….... 98

FIGURA 52 - Esquema de montagem do sistema camisa-anel de pistão no

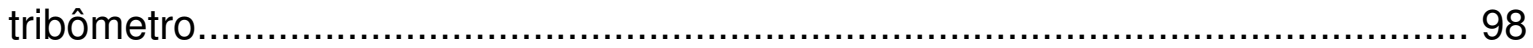

FIGURA 53 - Camisas HD utilizadas nos testes de bancada recíproco............. 100

FIGURA 54 - Anel de pistão utilizado nos testes de bancada recíproco............ 100

FIGURA 55 - Esquema do motor ciclo Otto à gasolina..................................... 102

FIGURA 56 - Resultados da medição da força de atrito no motor FLE, 1500 rpm,

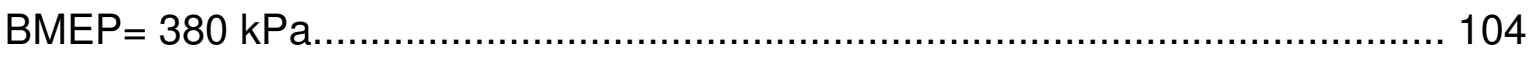

FIGURA 57 - Esquema de retirada de corpos-de-prova para análise Raram.... 109 FIGURA 58 - Resultados de medição da circularidade do diâmetro interno para camisa HD1 ............................................................................................

FIGURA 59 - Resultados de medição da circularidade do diâmetro interno para camisa HD2.

FIGURA 60 - Resultados de medição da circularidade do diâmetro interno para camisa HD4

FIGURA 61 - Resultados de medição da circularidade do diâmetro interno para camisa HD6

FIGURA 62 - Circularidade do diâmetro interno, camisa HD1. Altura 50 mm, (A) antes e (B) após a deposição do filme DLC................................................. 114

FIGURA 63 - Circularidade do diâmetro interno, camisa HD1. Altura 190 mm, (A) antes e (B) após a deposição do filme DLC 
FIGURA 64 - Medição do erro de retilineidade da camisa HD1. (A) antes e (B) após a deposição do filme DLC ............................................................... 116 FIGURA 65 - Medição do erro de cilindricidade da camisa HD1. (A) antes e (B) após a deposição do filme DLC............................................................. 118 FIGURA 66 - Medição do erro de cilindricidade da camisa HD6. (A) antes e (B) após a deposição do filme DLC.

FIGURA 67 - Evolução dos parâmetros da família Rk antes e após deposição do filme DLC nas camisas HD.

FIGURA 68 - Réplica da superfície brunida da camisa HD1 a $30 \mathrm{~mm}$ e 90․ (A) sem filme DLC. (B) com filme DLC.

FIGURA 69 - Réplica da superfície brunida da camisa HD2 a $90 \mathrm{~mm}$ e 180. (A) sem filme DLC. (B) com filme DLC.

FIGURA 70 - Réplica da superfície brunida da camisa HD4 a $30 \mathrm{~mm}$ e $180^{\circ}$. (A) sem filme DLC. (B) com filme DLC 122

FIGURA 71 - Réplica da superfície brunida da camisa HD6 a $30 \mathrm{~mm}$ e $90^{\circ}$. (A) sem filme DLC. (B) com filme DLC.

FIGURA 72 - Imagens MEV, camisa HD1 (imagens por elétrons retroespalhado) 123

FIGURA 73 - Imagens MEV, camisa HD1 (imagens por elétrons retroespalhado) 124

FIGURA 74 - Filme DLC acompanhando as imperfeições do substrato pela análise MEV (imagens por elétrons retro-espalhados). 125 FIGURA 75 - (A) Imagem da seção transversal obtida por MEV e (B) perfil da composição química semiquantitativa da camisa HD1 obtido por EDS 125 FIGURA 76 - (A) Imagem da seção transversal obtida por MEV e (B) perfil da composição química semiquantitativa da camisa HD4 obtido por EDS............. 126 FIGURA 77 - Difratograma da camisa referência................................... 127 FIGURA 78 - Difratograma da camisa HD1 .......................................... 127 FIGURA 79 - Difratograma da camisa HD4 ............................................. 127 FIGURA 80 - Resultados do COF para temperatura de óleo $120^{\circ} \mathrm{C}$. (A) COF com carga normal de $50 \mathrm{~N}$, (B) COF com carga normal de $100 \mathrm{~N}$. 130 FIGURA 81 - Imagens por MO dos corpos-de-prova após teste de bancada recíproca, camisas referência 
FIGURA 82 - Imagens por MO dos corpos-de-prova após teste de bancada recíproca, camisas HD1 $(2,5 \mu \mathrm{m})$.

FIGURA 83 - Imagens por MO dos corpos-de-prova após teste de banc recíproca, camisas HD4 $(12,5 \mu \mathrm{m})$. 132

FIGURA 84 - Aspectos visuais das camisas HD2 (A) e HD6 (B) após 10h de rodagem no ciclo de amaciamento

FIGURA 85 - Perfil de desgaste nas camisas HD após 10 h de rodagem no ciclo de amaciamento. 134

FIGURA 86 - Detalhe da camisa HD6 após ciclo de amaciamento mostrando delaminação do filme DLC na região de contato dos anéis de pistão. 135 FIGURA 87 - Aspecto visual da camisa HD2 (2,5 $\mu \mathrm{m})$ e camisas referência após completarem $500 \mathrm{~h}$ de teste de rodagem em ciclo de durabilidade 136 FIGURA 88 - Medição do desgaste das camisas HD após 500 h de teste de motor Diesel. 137

FIGURA 89 - Valores da pressão média de atrito (FMEP) nos regimes de operação do motor FLE.................................................................... 138

FIGURA 90 - Medição da rugosidade das camisas FL (10 mm do topo)........... 139

FIGURA 91 - Medição da rugosidade das camisas FL (45 mm de topo)........... 139 FIGURA 92 - Curva de desempenho do motor ciclo Diesel com camisas de referência e camisas com filme DLC na superfície interna.............................. 140 FIGURA 93 - Perfil de desgaste das camisas HD após $125 \mathrm{~h}$ de teste de motor ciclo Diesel e aspecto visual do filme DLC na região TDC. 142 FIGURA 94 - Desgaste dos anéis de pistão após 125 h de teste de motor ciclo Diesel. 143

FIGURA 95 - Espectros Raman para os diferentes casos do filme DLC analisados. 


\section{LISTA DE SIGLAS / ABREVIATURAS}

BDC "Bottom Dead Center" - região inferior de reversão dos anéis de pistão BSFC "Brake Specific Fuel Consumption" - consumo específico de combustível CBN nitreto de boro cúbico

COF "Coefficient of Friction" - coeficiente de atrito

CVD "Chemical Vapor Deposition" - deposição química em vapor

DLC "Diamond Like-Carbon" - filme a base de carbono ou carbonoso

EDS "Energy Dispersive Spectroscopy" - espectroscopia por energia dispersiva EGR "Exhaust Gas Returning" - retorno dos gases de escapamento FLE "Floating Liner Engine" - motor com sistema de camisa flutuante FMEP "Friction Mean Effective Pressure" - pressão média efetiva de atrito JCPDS “Joint Committee on Power Diffraction Standards".

MEV microscopia eletrônica de varredura

MO microscópio óptico

NOx óxido de nitrogênio

PACVD "Plasma Assisted Chemical Vapor Deposition"

PVD "Physical Vapor Deposition"

SCR "Selective Catalytic Reduction" - catalizador de redução seletiva

TDC “Top Dead Center" - região de reversão superior dos anéis de pistão 


\section{INTRODUÇÃO}

As questões energéticas e ambientais que circundam 0 desenvolvimento de motores à combustão interna são as mais discutidas atualmente em todos os países, evidenciando a necessidade da redução do consumo de combustível que resulta na redução dos níveis de emissão de $\mathrm{CO}_{2}$, assim como de outros elementos, como o óxido de nitrogênio (NOx) e os particulados sólidos provenientes da combustão de combustíveis fósseis. Assim, o interesse no desenvolvimento de componentes de baixo atrito e com maior durabilidade tem papel fundamental na redução do consumo de combustível em motores à combustão interna. A introdução de componentes de baixo atrito agrega novas tecnologias, como os revestimentos de superfície, que estão em pleno desenvolvimento para suportar esta demanda.

De acordo com ERNST e BARBEZAT (2008), fabricantes de caminhões estão sob uma crescente pressão para reduzir o consumo de combustível e os níveis de emissões. Os níveis permitidos de NOx e a emissão de particulados sólidos foram reduzidos em mais de 90\% durante a última década. A busca pela combustão mais eficiente através do aperfeiçoamento do sistema de injeção de combustível foi, em muitas ocasiões, comprometida mesmo com a introdução de novas tecnologias como os filtros de particulados e sistemas de pós-tratamento de gases de exaustão, como o catalizador de redução seletiva, também conhecido como "Selective Catalytic Reduction" (SCR), o coletor de NOx de mistura pobre, conhecido como "Lean NOx Trap" e o sistema que promove o reaproveitamento parcial dos gases de exaustão, conhecido como "Exhaust Gas Recirculation" (EGR) são algumas soluções aplicadas e em constante desenvolvimento para atender os limites restritos de emissões. Contudo, a técnica EGR tende a piorar a eficiência da combustão e aumenta a quantidade de fuligem no óleo lubrificante o que provoca maior desgaste em alguns componentes no motor, como por exemplo, a camisa de cilindro. Uma combustão ineficiente pode levar ao acúmulo de resíduos à base de carbono (carvão) na superfície do pistão e dos anéis de pistão, causando desgaste prematuro desses componentes, assim como nas camisas de cilindro.

De acordo com BASSHUYSEN e SCHÄFER (2004), apesar da participação específica do atrito entre os componentes depender do projeto do 
motor e das condições de operação, entre outros fatores, é geralmente aceito que o principal responsável pelo atrito é o sistema pistão-anel de pistão-camisa de cilindro. Dentre os principais potenciais de redução de atrito pode-se destacar o acabamento da camisa de cilindro, a força do anel de controle de óleo, a altura dos anéis e o uso de materiais com menor coeficiente de atrito.

Segundo MORGENSTERM et al. (2008), o filme de carbono amorfo hidrogenado tipo diamante $(\mathrm{a}-\mathrm{C}: \mathrm{H})$ apresenta uma combinação superior de comportamento frente ao desgaste e ao atrito, o que faz do DLC uma solução adequada para diversas áreas da tribologia.

Sabe-se que filmes a base de carbono tipo DLC são aplicados comercialmente em alguns componentes de motor, como anéis e pino de pistão, com objetivo melhorar as propriedades de desgaste e na redução do atrito do motor, entretanto, não se conhece a utilização deste tipo de revestimento aplicado no diâmetro interno de camisas de cilindro. Testes conduzidos por SATO et al. (2004) em um motor ciclo Diesel adaptado para medir a força de atrito imposta pelo conjunto pistão na parede interna do cilindro comprovaram que um tipo de filme DLC aplicado na superfície interna do cilindro reduziu da pressão de atrito equivalente do motor em até $10 \%$.

Com base no cenário atual, este trabalho analisa a viabilidade técnica de se utilizar um filme DLC amorfo hidrogenado, com uma camada intermediaria de silício, depositado sobre a superfície interna de camisa de cilindro acabada, fabricada em ferro fundido cinzento.

A realização deste trabalho concedeu a oportunidade de participar em alguns congressos científicos com a publicação de artigos como o 56ํㅜ congresso brasileiro de cerâmica com o artigo intitulado "Caracterização e desempenho de um filme à base de carbono tipo DLC para uso em camisas de cilindro para redução de atrito", o congresso SAE International 2012 com o artigo de numero 2012-01-1339 intitulado "Application of DLC coating in cylinder liner for friction reduction" que proporcionou uma publicação em revista indexada, e finalmente o reconhecimento pela Associação Brasileira Automotiva (AEA) com uma menção honrosa durante o evento "Premio AEA 2012 - Projetos de meio ambiente".

Os resultados obtidos no presente trabalho estão apresentados a seguir, bem como a revisão bibliográfica pertinente. 


\section{OBJETIVOS}

O objetivo do trabalho foi avaliar a viabilidade técnica em se utilizar um filme DLC amorfo hidrogenado com gradiente de composição química, proveniente da dopagem com silício, em camisas de cilindro na redução do atrito do motor à combustão interna. Para suportar a concretização deste objetivo, as seguintes verificações foram feitas:

- Validar o processo de deposição do filme DLC para camisas de cilindro pelo processo PACVD por análises de caracterização das propriedades físico-químicas do filme depositado e avaliação da integridade dimensional das camisas de cilindro revestidas;

- Verificar a redução do coeficiente de atrito por meio de testes de bancada e de motores à combustão (ciclo Otto e Diesel) em banco de prova (dinamômetro);

- Avaliar a influência do filme DLC na durabilidade dos componentes após teste, anéis de pistão e camisas de cilindro, pelo desgaste apresentado nas superfícies de contato;

- Confirmar a viabilidade técnica do uso do filme DLC na redução do atrito com auxílio de dois testes motor ciclo Diesel, sendo o primeiro montado com camisas referência (sem filme DLC) e o segundo montado com camisas revestidas com filme DLC, para medição do consumo especifico de combustível;

- Confirmar a integridade do filme DLC após teste de motor à combustão por analises de espectroscopia Raman em regiões da camisa de cilindro expostas a alta temperatura da combustão e o contato metal-metal dos anéis de pistão. 


\section{REVISÃO DA LITERATURA}

\subsection{Perdas Mecânicas em motores à combustão interna}

Segundo ÖNER et al. (2009) e RICHARDSON (2000), observa-se na literatura que aproximadamente $40 \%$ da energia consumida num motor ciclo Diesel é convertida em trabalho útil e até $15 \%$ do total da energia é perdida em atrito, conforme mostra a FIG. 1. Um bom caminho para aumentar o trabalho efetivo num motor à combustão interna é a redução das perdas por atrito. Embora a distribuição do atrito entre os componentes do motor dependa de muitos fatores, como por exemplo: projeto do motor, o regime de operação, também é aceito que o sistema pistão-anel-camisa de cilindro seja um dos maiores contribuintes para o atrito. Consequentemente, esses componentes são naturalmente selecionados para serem melhorados devido à oportunidade de reduzir o atrito (TOMANIK e FERRARESE, 2006). Alinhado a esta afirmação, JOSAK et al. (2004) e TOMANIK (2008) enfatizam também que a mudança na rugosidade da superfície de trabalho de uma camisa de cilindro é considerada como uma das variantes-chave para reduzir as perdas por atrito.

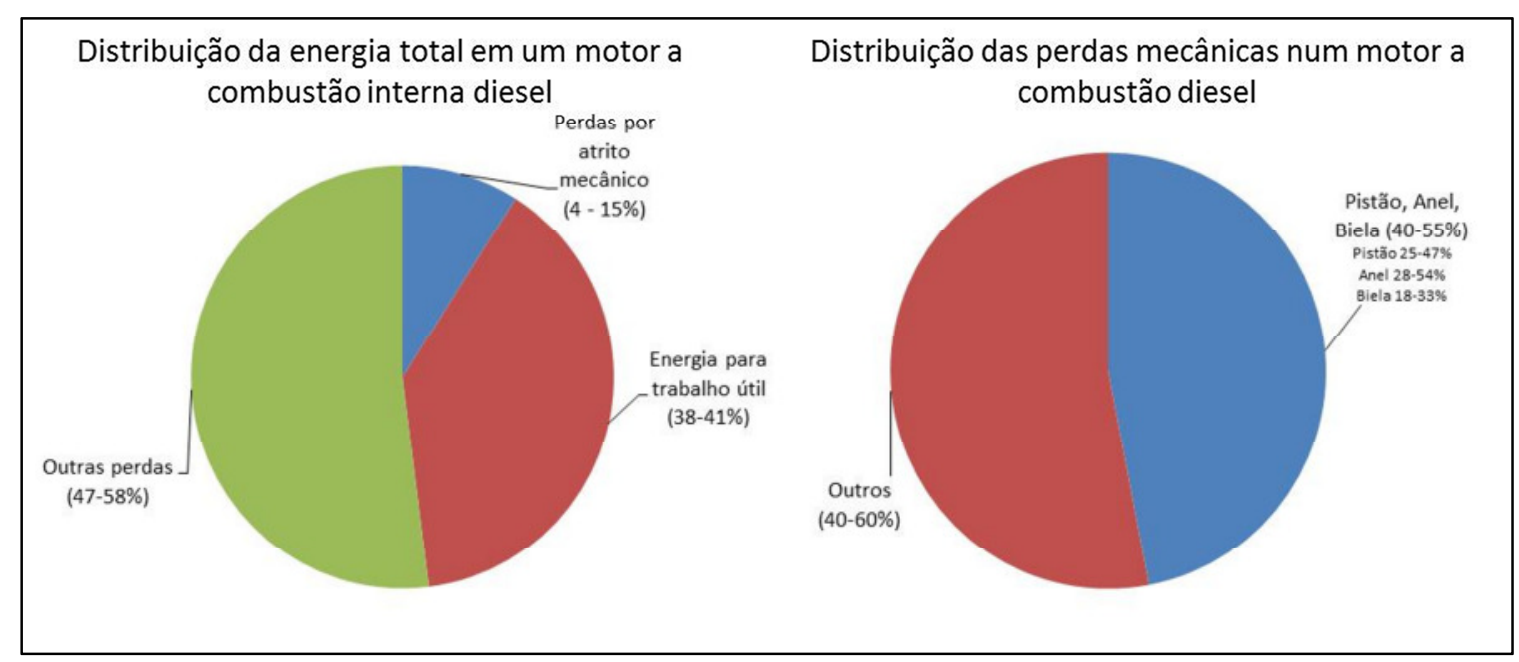

FIGURA 1 - Distribuição da energia total utilizada e das perdas mecânicas em um motor ciclo Diesel (RICHARDSON, 2000).

Num motor ciclo Otto as perdas mecânicas podem chegar a 10\% do total da energia gerada pelo combustível consumido. Essa quantidade de atrito 
pode corresponder a quase $25 \%$ da potência específica ${ }^{1}$ a plena carga de um motor, sendo superior em cargas parciais. Em vazio ou marcha lenta, $100 \%$ da potência indicada ${ }^{2}$ é consumida pelo atrito. A perda por atrito varia com o tipo de motor e a condição de operação ou de carregamento. A FIG. 2 mostra a distribuição de energia em um motor ciclo Otto com deslocamento volumétrico de 2.0 litros em plena carga a 5000 rpm (SCHELLING apud TOMANIK e FERRARESE, 2006).

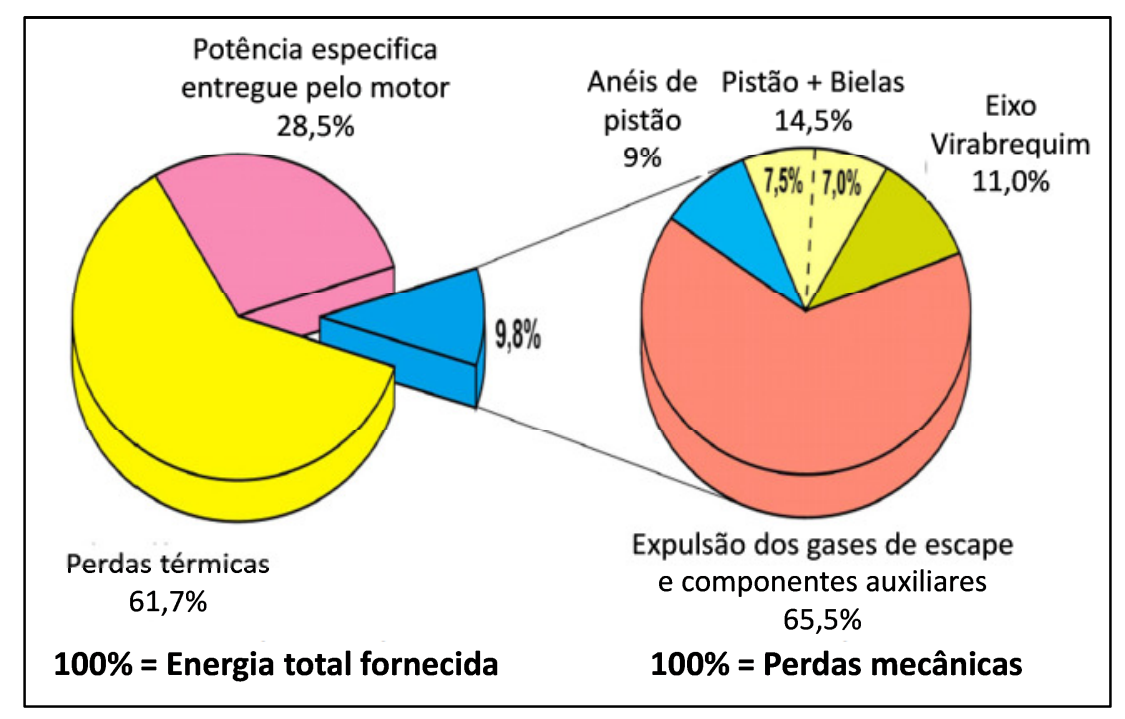

FIGURA 2 - Distribuição da energia total e das perdas mecânicas em um motor ciclo Otto (SCHELLING apud TOMANIK e FERRARESE, 2006).

A procura por redução de atrito é contínua, mas o interesse em desenvolver componentes de baixo atrito tem crescido recentemente, em especial pela demanda de redução de emissões. Sabe-se que as perdas mecânicas num motor à combustão aumentam com o aumento da velocidade de rotação do eixo virabrequim. Uma forma de se observar isso é através de testes de bancada, onde se mede o valor do torque de atrito necessário para manter os respectivos subconjuntos que compõem um motor à combustão em pleno funcionamento em diferentes faixas de rotação. A FIG. 3 mostra como o torque de atrito de cada subconjunto de um motor ciclo Otto, com deslocamento volumétrico de 2,0L,

\footnotetext{
${ }^{1}$ Potência específica $(\mathrm{Pe})$ é a potencia medida no eixo de manivelas do motor ou no freio do dinamômetro quanto instalado em banco de provas, unidade expressa em kW ou CV (HEYWOOD, 1988).

${ }^{2}$ Potência indicada $(\mathrm{Pi})$ é a potência total desenvolvida pelos cilindros do motor devido à pressão do fluido motor (combustão) sobre os pistões. É determinado a partir de um indicador de pressão localizado dentro da câmara de combustão (HEYWOOD, 1988).
} 
dotado de turbo compressor, e com injeção direta de combustível se comporta em diversas velocidades de rotação do eixo virabrequim.

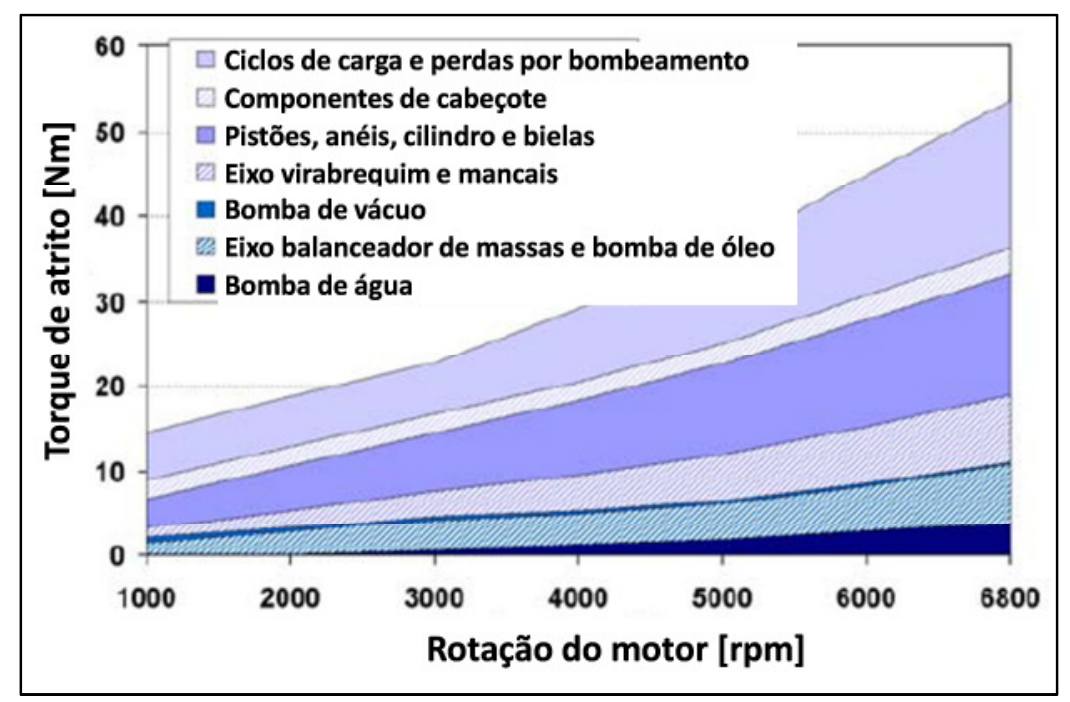

FIGURA 3 - Torque de atrito em função da rotação do motor ciclo Otto (BLAXILL et al., 2009).

A FIG. 4 mostra um gráfico com a estimativa de redução de consumo de combustível baseada no atrito total de motores ciclo Diesel e Otto estabilizados numa rotação de 2000 rpm (BASSHUYSEN e SCHÄFER, 2004). Por esse gráfico é possível verificar que uma redução de $10 \%$ do atrito num motor pode gerar economia de aproximadamente $2 \%$ tanto para um motor ciclo Diesel como para um motor ciclo Otto.

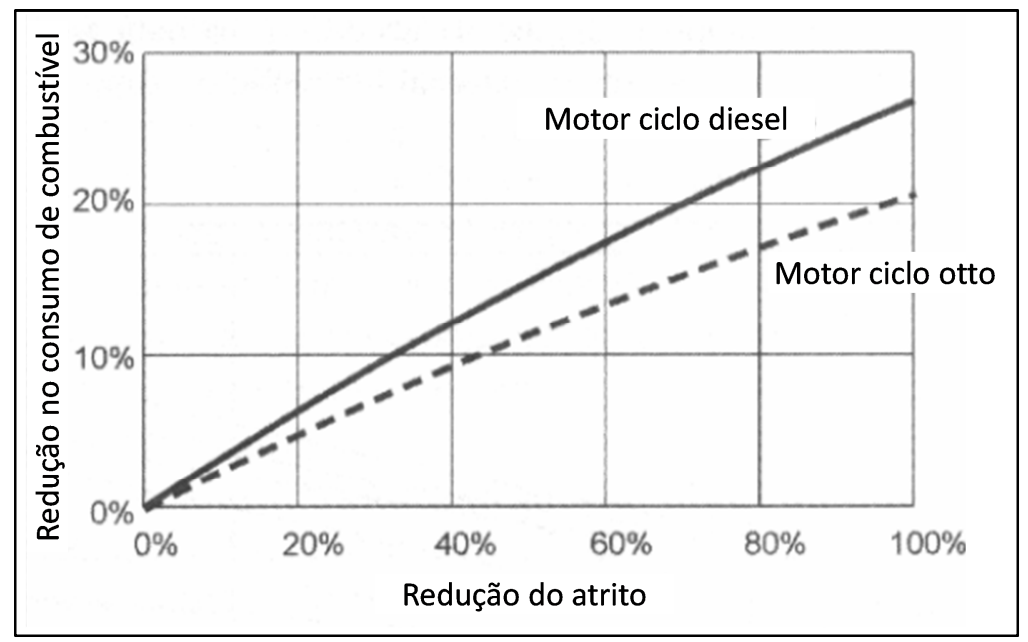

FIGURA 4 - Estimativa de economia de combustível vs. redução de atrito (BASSHUYSEN e SCHÄFER, 2004). 


\subsection{Motores à combustão interna}

Motores à combustão interna, também denominada de máquinas térmicas motoras, são aqueles que transformam a energia química dos combustíveis em trabalho mecânico (o fluido de trabalho consiste nos produtos da combustão). Os motores à combustão interna podem ser classificados em:

- Quanto a propriedade do gás na admissão: à ar (Diesel) à mistura arcombustível (Otto);

- Quanto à ignição: por centelha ("spark ignition”) ou por compressão ("compression ignition");

- Quanto ao movimento do pistão: alternativo (ciclo Otto, Diesel) ou rotativo (ciclo Wankel, Quasiturbine);

- Quanto ao ciclo de trabalho: 2 tempos ou 4 tempos;

- Quanto ao número de cilindros: monocilíndricos ou policilíndricos;

- Quanto à disposição dos cilindros: em linha, opostos (boxer), em V ou em estrela (radial);

- Quanto à utilização: marítimos, estacionários, rodoviários, etc. (BASSHUYSEN e SCHÄFER, 2004).

\subsubsection{Motores de ignição por centelha}

Os motores cuja energia de ativação é fornecida por uma faísca elétrica são chamados de motores de ignição por centelha ou motores ciclo Otto, cuja principal característica é a combustão ocorrer praticamente a volume constante. Nesses motores, que podem operar em ciclos de quatro ou dois tempos, o ar e o combustível são normalmente misturados antes de entrar na câmara (no sistema de admissão), usando um carburador ou um sistema de injeção de combustível. Os combustíveis utilizados por estes motores são normalmente hidrocarbonetos leves de alto poder calorífico, como gasolina, álcool, gás natural ou misturas semelhantes (HEYWOOD, 1988).

\subsubsection{Motores de ignição por compressão}

Nos motores de ignição por compressão (ou motores ciclo Diesel) a combustão acontece teoricamente à pressão constante, caracterizando-se pela injeção de combustível diretamente na câmara (ou numa pré-câmara), onde o ar 
encontra-se aquecido devido à compressão. Os combustíveis que são utilizados neste tipo de motor são normalmente hidrocarbonetos mais pesados e menos voláteis, como o óleo Diesel.

Estes motores são normalmente maiores e mais pesados que os motores ciclo Otto sendo, portanto mais utilizados em veículos utilitários como caminhões e embarcações e, finalmente, em uso estacionário, como geradores. Podem operar ainda em ciclos de dois e quatro tempos, sendo este último o mais comum. Os motores ciclo Diesel diferem em relação à combustão, dos motores de ciclo Otto pelo fato de operarem sempre com excesso de ar proporcionando uma combustão mais completa e, portanto, emissão de teores de CO muito mais baixa (HEYWOOD, 1988).

\subsubsection{Potência e Torque}

O torque do motor representa a habilidade deste em produzir trabalho e é medido em freios dinamométricos acoplados ao eixo do motor. A potência representa a taxa de trabalho na unidade de tempo e é o produto do torque pela velocidade angular do motor. Tanto a potência calculada como o torque medido em um dinamômetro são denominados potência no freio "brake power" ou potência efetiva e torque no freio "brake torque". O torque no freio ( $\left.T_{b}\right)$ é, então, dado pela equação 1 :

$$
T_{b}=F \cdot b
$$

onde

$\mathrm{F}$ é a força medida no transdutor do freio [N]

b é o comprimento do braço de alavanca do freio [m].

A potência efetiva no freio $\left(P_{b}\right)$ é dada pela equação 2 :

$$
P b=2 . \pi . N . T b
$$

onde $\mathrm{N}$ é a velocidade angular do virabrequim (HEYWOOD, 1988). 


\subsubsection{Eficiência mecânica}

A potência bruta ou potência indicada $\left(P_{i g}\right)$ é a potência total desenvolvida nos cilindros devido à pressão do fluido motor sobre os pistões. Esta potência é determinada a partir de um indicador de pressão localizado dentro da câmara de combustão. Sabe-se que parte desta potência é perdida pelo trabalho de bombeamento. A outra parcela é utilizada para superar as forças de atrito dos anéis, êmbolos e demais componentes mecânicos. A soma destas parcelas é denominada potência de atrito $\left(P_{f}\right)$ conforme equação 3 :

$$
P_{i g}=P_{b}+P_{f}
$$

A potência de atrito é difícil de ser medida com precisão. Uma forma de medi-la é girar o motor sem ignição (desligado), com o auxílio de um motor elétrico, e medir-se em dinamômetro a potência requerida para vencer todos o atrito, o que será, aproximadamente, a potência de atrito, conforme mostrado na FIG. 3, onde a força de atrito foi medida para cada subconjunto do motor.

A relação entre a potência efetiva liberada pelo motor e a potência indicada é a eficiência mecânica, que é dada pela equação 4:

$$
\eta_{m}=\frac{P_{b}}{P_{i g}}=1-\frac{P_{f}}{P_{i g}}
$$

onde

$\eta_{\mathrm{m}}=$ eficiência mecânica;

$P_{f}=$ potência de atrito $[\mathrm{W}]$;

$\mathrm{P}_{\mathrm{b}}=$ potência no freio $[\mathrm{W}]$;

$\mathrm{P}_{\mathrm{ig}}=$ potência indicada bruta por ciclo $[\mathrm{W}]$.

Como a potência de atrito inclui a potência de bombeamento dos gases, a eficiência mecânica será influenciada pela velocidade e pelo projeto do motor e, ainda, pela posição da borboleta, que mede indiretamente a carga aplicada sobre o motor (HEYWOOD, 1988). 


\subsubsection{Pressão média efetiva}

O torque é uma medida da capacidade de um motor de produzir trabalho, e depende do tamanho do motor. Uma relação mais útil na medida do desempenho de um motor é obtida dividindo-se o trabalho indicado por ciclo pelo volume deslocado pelo motor. Desta forma, atinge-se um parâmetro com unidades de força por unidade de área, chamado pressão média efetiva ou pressão indicada média equivalente (IMEP) "Indicate Mean Effective Pressure", dado pela equação 5:

$$
I M E P=\frac{P_{i g} \cdot \eta_{r}}{V_{d} \cdot N}
$$

onde

IMEP = pressão indicada média equivalente [Pa];

$\eta_{r}=$ número de cursos de potência para cada ciclo, onde $\eta_{r}=2$ para motores 4 tempos e 1 para motores 2 tempos;

$\mathrm{N}=$ rotação do motor $\left[\mathrm{s}^{-1}\right]$;

$\mathrm{V}_{\mathrm{d}}=$ volume deslocado pelo motor $\left[\mathrm{m}^{3}\right]$.

A pressão média efetiva é um parâmetro de desempenho muito utilizado para o projeto e o desenvolvimento de motores, bem como para medidas da eficiência destes. O parâmetro mais comumente utilizado, uma vez que a potência bruta é difícil de ser determinada, é a pressão média efetiva no freio (BMEP), ou "Brake Mean Effective Pressure", cuja determinação prática é muito simples de ser feita em dinamômetros, sendo caracterizada pela equação 6:

$$
B M E P=\frac{P_{b} \cdot n_{m}}{V_{d} \cdot N}
$$

onde

BMEP = pressão média efetiva no freio [Pa], (HEYWOOD, 1988). 


\subsubsection{Consumo específico de combustível}

Em testes de motores, o consumo de combustível é medido como a taxa de vazão em função do fluxo de massa por unidade de tempo $\left(m_{f}\right)$. $O$ parâmetro mais utilizado é o do consumo específico de combustível também conhecido como "Brake Specific Fuel Consumption" (BSFC), que é a taxa de fluxo de massa do combustível por unidade de potência. O BSFC mede quão eficiente é um motor utilizando combustível fornecido para produção do trabalho, de acordo com a equação 7:

$$
B S F C=\frac{m_{f}}{P}
$$

Para o presente trabalho o BSFC é apresentado com a seguinte unidade, como mostra a equação 8:

$$
B F S C=\frac{m_{f}\left[\frac{g}{h}\right]}{P[k W]}=\frac{g}{k W \cdot h}
$$

Valores baixos de BSFC são desejados. Em motores ciclo Otto os valores típicos de BSFC são ao redor de $270 \mathrm{~g} / \mathrm{kW}$.h. Para motores ciclo Diesel os melhores valores estão abaixo de 200 g/kW.h, (HEYWOOD, 1988).

\subsection{As novas leis de emissões para redução do consumo de combustível}

Até 1988 a emissão de particulados sólidos provenientes da combustão do combustível diesel não era regulamentada. A partir de 1988 até 2010 uma variedade de composições do óleo diesel, de propriedades do diesel e de tratamentos pós-combustão foram incorporados para reduzir a emissão de particulados sólidos e NOx. Muitas dessas mudanças impactaram na durabilidade da camisa de cilindro em relação ao seu desgaste, entretanto, outras foram benéficas diminuindo o desgaste na superfície interna de trabalho. A FIG. 5 monstra a magnitude das mudanças nas leis de controle de emissões ao longo dos anos nos Estados Unidos e na Europa para motores ciclo Diesel (DAM et al., 2011). 
No Brasil, o programa de controle da poluição do ar por veículos automotores (Proconve) entrou na sua $7^{\text {a }}$ fase - que não tem prazo determinado de duração - e, desta vez, institui uma diminuição expressiva nos níveis de emissões permitidos para veículos a Diesel fabricados a partir de $1^{\circ}$ de janeiro de 2012. Os motores ciclo Diesel deverão ser adaptados para atender às normas da Euro 5, instituído como Proconve P7 no Brasil. O programa brasileiro é uma adaptação à atual realidade das metodologias internacionais, principalmente das normas da Euro 5, já em vigor na Europa, e que se encontra na quinta fase de diminuição progressiva de emissão de gases.

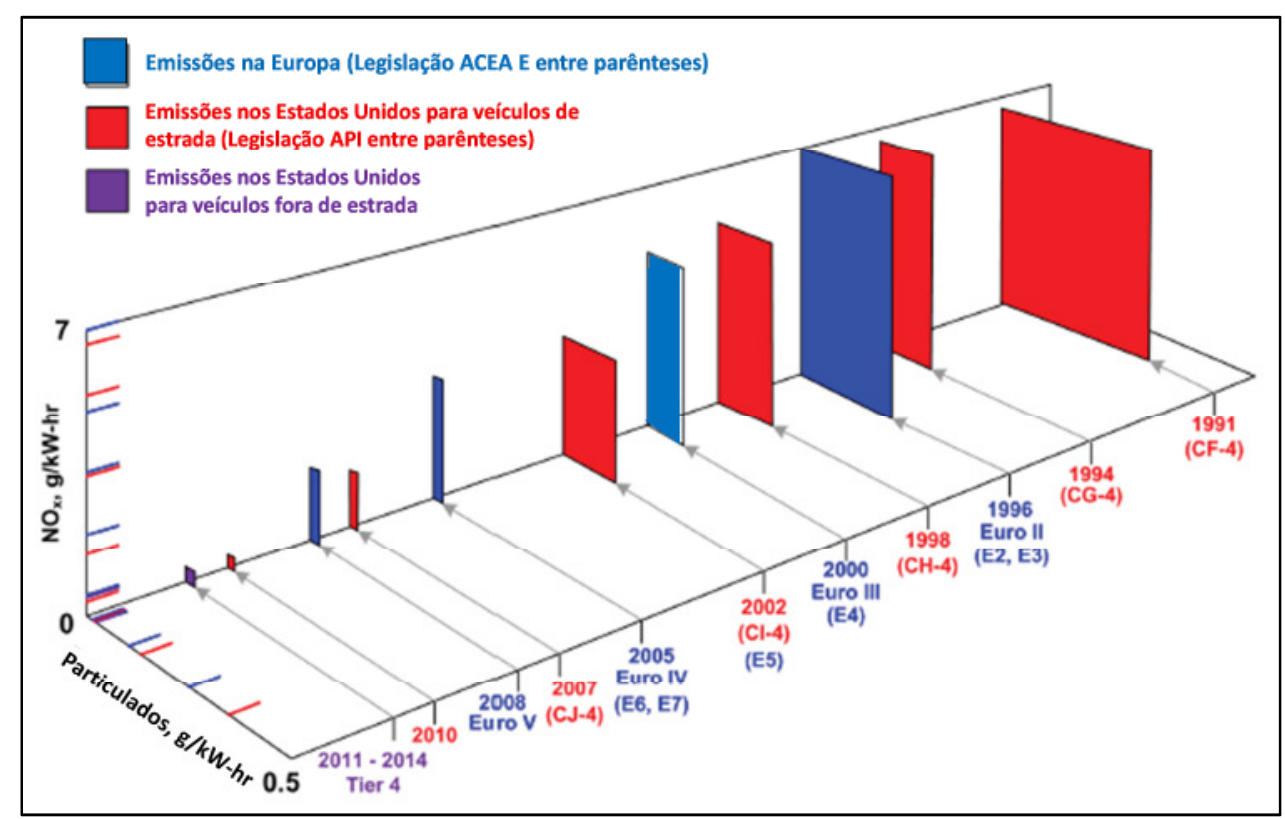

FIGURA 5 - Controle de emissão para veículos a Diesel nos Estados Unidos e na Europa de 1991 a 2011 (DAM et al., 2011).

A FIG. 6 apresenta uma análise dos quatro principais produtos de combustão em motores ciclo Diesel responsáveis pelos níveis de emissões de poluentes e as sete fases do PROCONVE, mostrando a evolução no controle dos limites definidos no Brasil (RUBIM, 2012).

Com a necessidade de atender a legislações ambientais cada vez mais rígidas, a indústria automotiva tem sido guiada pelo desafio de reduzir emissões e consumo de combustível. Neste aspecto, a redução das perdas mecânicas geradas pelo atrito entre as peças móveis num motor apresenta grande potencial de trabalho a ser desenvolvido. $O$ principal desafio a ser vencido durante 0 
processo de desenvolvimento de um conjunto motriz é obter redução das perdas por atrito entre os anéis de pistão e as camisas de cilindro mantendo o compromisso da oferta de óleo na superfície de deslizamento dos anéis e na vedação dos gases provenientes da combustão. Assim, grandes esforços têm sido aplicados no desenvolvimento de pacotes de anéis e camisas de cilindro, com a finalidade de diminuir as forças de contato entre estes componentes (DAM et al., 2001).

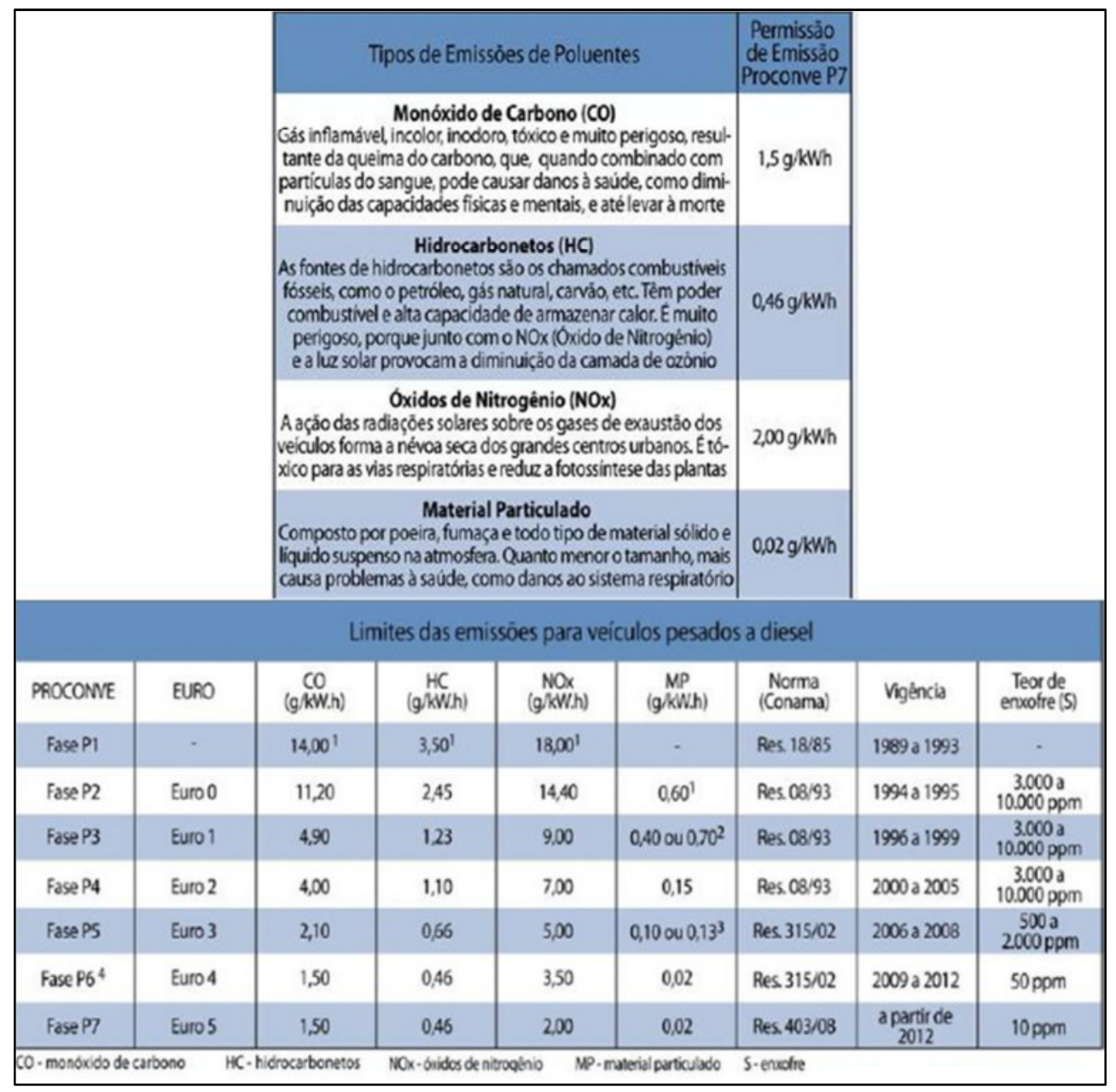

FIGURA 6 - Limites de emissões para veículos a Diesel no Brasil (RUBIM, 2012).

\subsection{Camisa de cilindro}

De acordo com HEYWOOD (1988), a camisa de cilindro é um elemento estático que compõe a estrutura do bloco, proporcionando um sistema fechado necessário para o processo de transformação da energia. Além disso, promove a 
troca térmica do calor gerado na combustão com a água ou o ar que circulam ao redor da camisa.

A mistura de combustível, ao ser admitida dentro do cilindro, entrará em combustão espontânea após ser comprimida (óleo diesel) ou por intermédio de faísca de ignição criada dentro da câmara durante a compressão da mistura (álcool e gasolina). A expansão dos gases de combustão ocorrerá dentro de um sistema fechado, para que parte da energia gerada impulsione o pistão para baixo e assim movimente o eixo virabrequim transformando, consequentemente, a energia em movimento (HEYWOOD, 1988).

A camisa de cilindro também é responsável pela dissipação do calor, gerado na câmara de combustão, para o bloco do motor ou diretamente para uma galeria de água, dependendo do projeto da camisa e do tipo de aplicação, conforme ilustra a FIG. 7 (BASSHUYSEN e SCHÄFER, 2004).

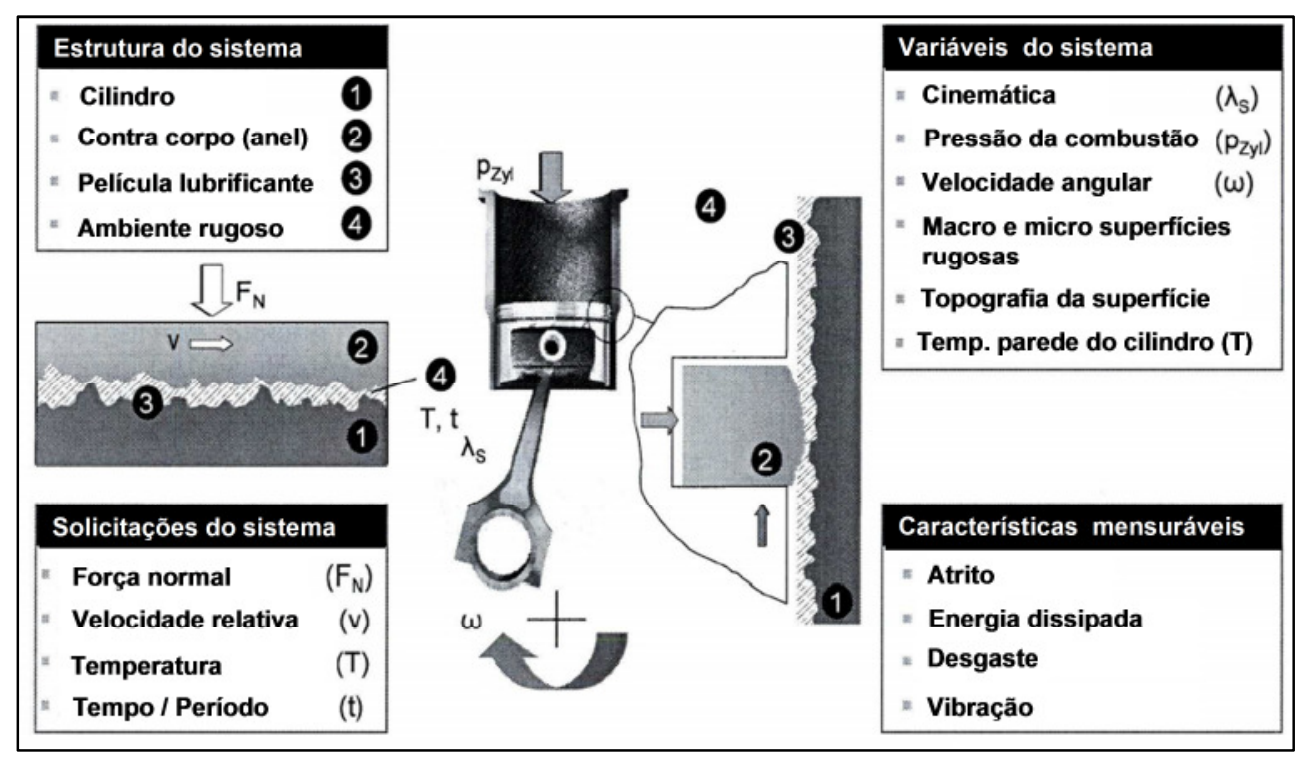

FIGURA 7 - Interação cilindro-pistão-anel no motor à combustão interna (PISCHINGER, 2009).

Levando em conta o tipo de material e a aplicação, a classificação das camisas de cilindro pode ser feita como descrito:

Camisa de cilindro por inserção: a técnica de inserção é normalmente usada para camisas de cilindro aplicadas em blocos de motores fabricados em ferro fundido ou alumínio. As camisas podem ser inseridas no bloco do motor através de varias técnicas como interferência, interferência a 
quente ou deslizamento. Desta forma têm-se as chamadas "camisas secas" que dissipam calor diretamente ao bloco do motor e as "camisas molhadas" que dissipam calor para uma galeria de água que separa o diâmetro externo da camisa e o bloco do motor, conforme mostra a FIG. 8.

Camisa de cilindro por adesão ou fundida ao bloco do motor: a técnica da adesão é utilizada para blocos de motores em alumínio ou magnésio. As camisas de cilindro são geralmente em ferro fundido e apresentam algumas características no diâmetro externo para garantir uma boa aderência metálica e/ou mecânica no bloco do motor. As camisas de cilindro são montadas num molde de fundição do bloco do motor e após o vazamento do metal liquido e posterior solidificação, garante-se uma boa retenção das camisas no bloco para futuras operações de usinagem. Neste caso, por não haver uma galeria de água entorno das camisas, são designadas como camisas secas.

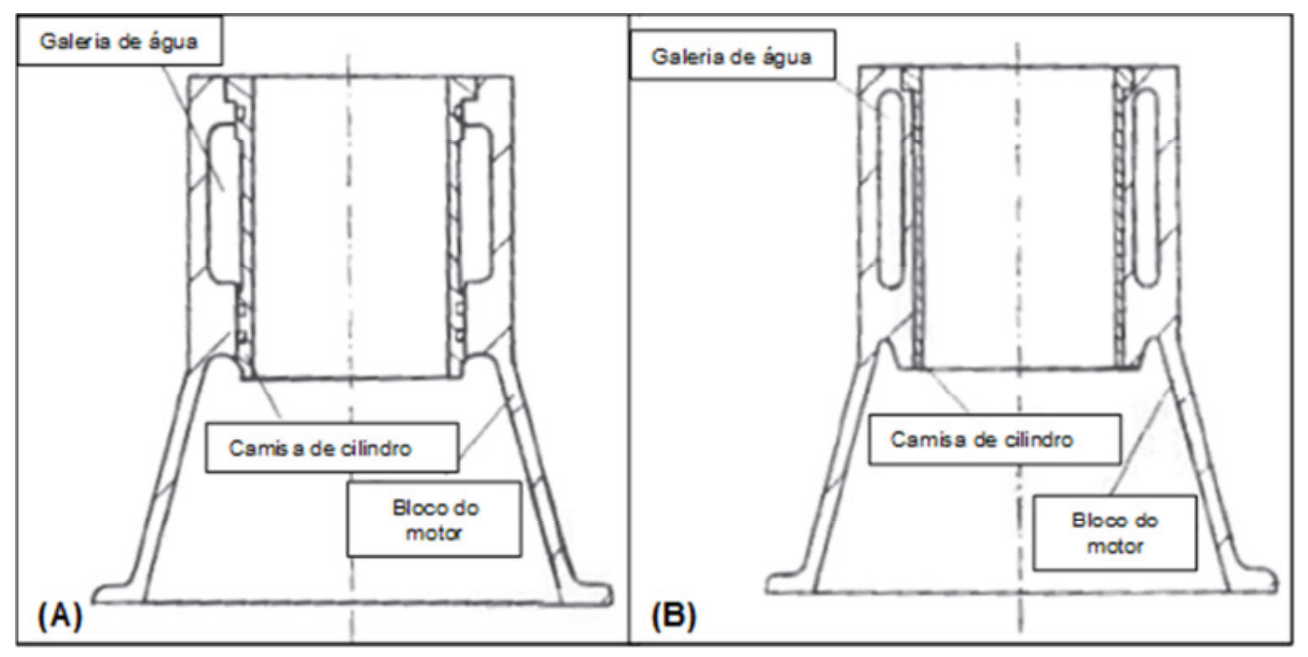

FIGURA 8 - (A) ilustração da camisa molhada, (B) ilustração da camisa seca (BASSHUYSEN e SCHÄFER, 2004).

No intuito de se obter melhor padronização no uso das denominações utilizadas para a identificação das partes que compõem uma camisa de cilindro, a FIG. 9 define os principais termos utilizados para camisas de cilindro dos tipos seca e molhada (MAHLE, 2010). 


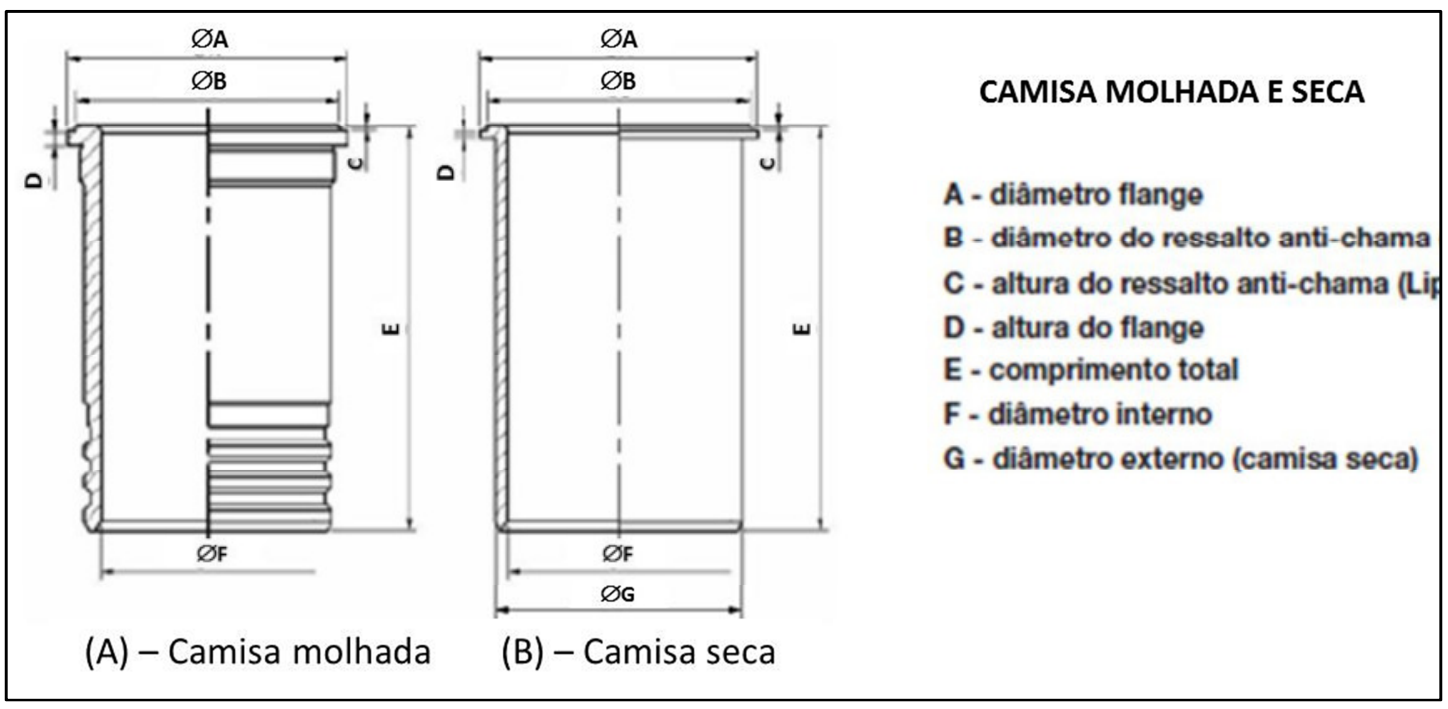

FIGURA 9 - Principais termos utilizados para camisas de cilindro, onde (A) camisa molhada e (B) camisa seca (MAHLE, 2010).

A camisa de cilindro deve ser projetada levando em consideração todas as forças atuantes no sistema, como o carregamento estático de compressão, gerado pelo torque dos parafusos de fixação que unem o cabeçote ao bloco de motor, o carregamento dinâmico e térmico gerados, respectivamente, pela oscilação do pistão e pela explosão do combustível na câmara de combustão. De forma geral, o material da camisa de cilindro deve possuir baixo coeficiente de atrito, ser bom condutor de calor e apresentar boa resistência à fadiga (PERINI, 2008; MAHLE, 2010).

No que se refere ao carregamento térmico imposto pela queima do combustível, a região mais crítica em uma camisa de cilindro é o ponto de reversão superior dos anéis de pistão, conhecido também como "Top Dead Center" (TDC). Assim como o pistão e os anéis de primeiro canalete, a região superior da camisa de cilindro é exposta a uma onda de calor proveniente da queima da mistura combustível durante o funcionamento do motor e, portanto, requer uma dissipação térmica elevada. Caso contrário, problemas como engripamento dos anéis por falta de lubrificação podem ocorrer. A FIG. 10 ilustra uma simulação numérica típica de elementos finitos onde, a partir de um modelo matemático do bloco do motor e algumas condições de carregamento térmico impostas obteve-se um modelo que mostra a expectativa do gradiente de temperatura nos quatro cilindros do motor em questão. 


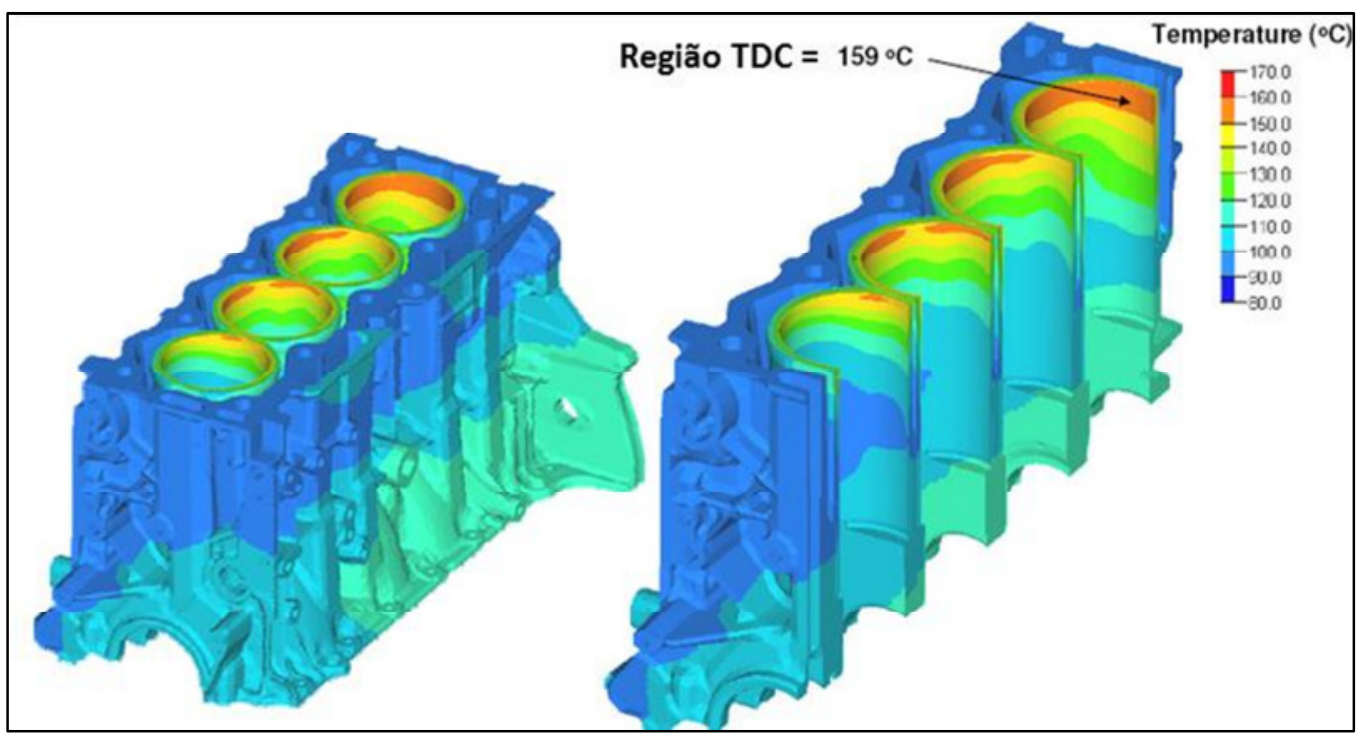

FIGURA 10 - Gradiente térmico típico em camisas de cilindro gerado por simulação de elementos finitos em um motor ciclo Otto.

Além das condições de carregamento observadas, é preciso garantir também uma boa relação tribológica com os anéis de pistão que irão desenvolver o movimento de translação vertical, em contato com a superfície interna acabada do cilindro.

\subsection{Anéis de pistão e sua interação com a camisa de cilindro}

Os anéis de pistão são retentores metálicos responsáveis basicamente por duas funções primordiais no funcionamento de um motor à combustão interna: manter os gases pressurizados da combustão na parte superior do pistão e a segunda função, que se tornou mais importante nos últimos tempos em razão do maior rigor das normas de emissões, manter o óleo do motor abaixo do pistão (ANDERSSON, 2003). Esta segunda função evita o consumo excessivo de óleo lubrificante durante o funcionamento do motor e por consequência a emissão de poluentes resultantes desta queima (RABUTÉ e TIAN, 2001). Além destas funções, os anéis também cumprem importante papel na dissipação térmica do pistão, conduzindo calor do pistão para a parede da camisa de cilindro ou para o bloco do motor (PRIEST e TAYLOR, 2000).

Para atingir seu propósito, os anéis do pistão devem estar em contato constante com a camisa de cilindro, bem como com a face superior e inferior do canalete do pistão (FERGURSON, 1985). O contato com a parede do cilindro é 
mantido pela ação de mola do anel, também chamada de força tangencial, que faz 0 anel expandir radialmente contra o cilindro e pela pressão dos gases que atuam atrás do anel (BASSHUYSEN e SCHÄFER, 2004).

A FIG. 11 mostra as forças atuantes sobre um anel de pistão (ANDERSSON et al., 2002). O anel está sujeito a esforços devido ao contato com o pistão, como o esforço superior da canaleta $\left(F_{\text {sup }}\right)$ e inferior $\left(F_{\text {inf }}\right)$, e a pressão exercida pelos gases entre $o$ anel e o fundo da canaleta $\left(P_{\text {canalete }}\right)$. Esforços de atrito também estão presentes, como $o$ atrito entre $o$ anel e a parede da camisa de cilindro $\left(F_{\text {atrito }} / F_{\text {contato }}\right)$. Devido à sua massa em aceleração, o anel também está sujeito aos esforços de inércia ( $F_{\text {inercia }}$ e a um momento em torno de seu eixo $\left(\mathrm{M}_{\text {total }}\right)$.

Além de todas essas componentes existe também a força de mola do anel $\left(F_{\text {tensão }}\right)$, que é resultado do próprio processo de fabricação do anel, e que the proporciona um efeito de mola contra as paredes do cilindro.

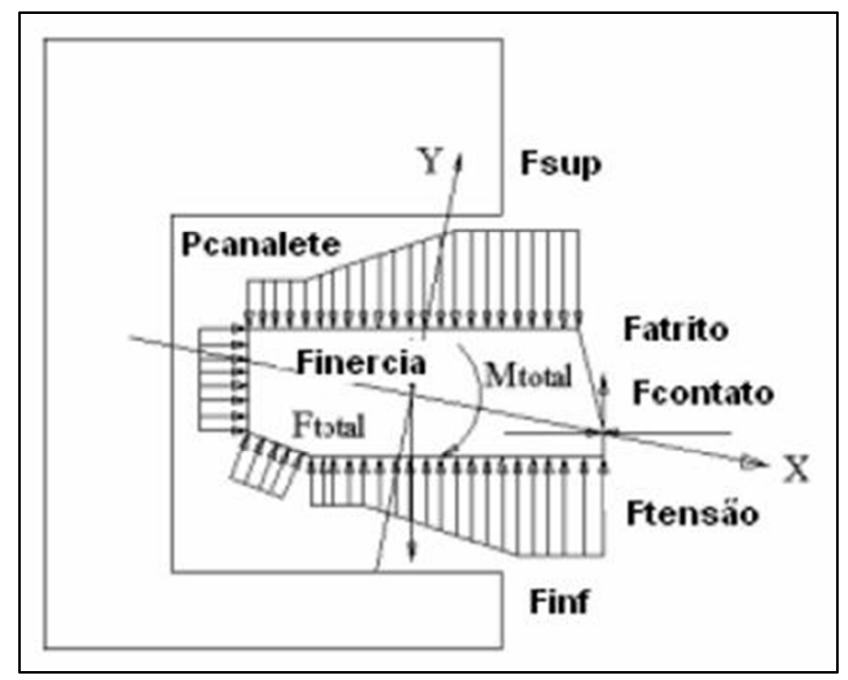

FIGURA 11 - Forças atuantes no anel de pistão (ANDERSSON et al., 2002).

A pressão dos gases na câmara de combustão aumenta o contato radial e axial com o canalete do pistão (GUIBET e FAURE, 1997). O contato axial alterna entre a face superior e inferior do canalete devido à influência da massa do anel, da pressão de combustão e do atrito com o cilindro e com o canalete (GANESAN, 1995). 


\subsection{Materiais utilizados em camisas de cilindro}

Segundo MARTINS (2006), a escolha do material para a camisa de cilindro varia segundo a aplicação de motor e o seu projeto que deve respeitar as condições impostas pelo bloco do motor. No entanto, características como alta resistência ao desgaste e rigidez são essenciais. Assim sendo, algumas ligas de ferro fundido são preferíveis, e sua microestrutura pode apresentar parte do carbono sob a forma de grafita ou cementita $\left(\mathrm{Fe}_{3} \mathrm{C}\right)$.

Segundo CHIAVERINI (1988), o ferro fundido cinzento é uma liga ferrocarbono-silício que apresenta teores de carbono geralmente acima de 2,0\% em peso, quantidade essa superior à que pode ser retida em solução sólida na austenita, o que resulta na formação de carbono parcialmente livre, na forma de veios ou lamelas de grafita. Outras morfologias de grafita podem ser encontradas como a vermicular e a nodular.

De acordo com PISCHINGER (2007), camisas utilizadas em motores ciclo Diesel de grande potência são quase sempre feitas de ferro fundido, pois esses motores detêm elevado carregamento mecânico e necessitam dissipar calor da câmara de combustão. A microestrutura do ferro fundido cinzento deve apresentar uma matriz perlítica, isenta de ferrita e exibir uma malha eutética fechada.

A TAB. 1 contém alguns tipos de ferro fundido utilizados em camisas de cilindro de acordo com as normas DIN e especificação alemã VDG-Merkblatt.

TABELA 1 - Características de materiais para camisas de cilindro

\begin{tabular}{cccc}
\hline & Grafita lamelar & Grafita vermicular & Grafita esferoidal \\
\hline Denominação & GJL-250 & GJV-400 & GJS-600 \\
Norma & DIN EN 1561:1997 & VDG-W50:2002 & DIN EN 1563:2005 \\
Carbono C [\%] & $2,90-3,70$ & $3,4-3,9$ & $3,50-3,70$ \\
Silício Si [\%] & $1,80-2,70$ & $1,9-2,35$ & $2,30-2,70$ \\
Manganês Mn [\%] & $0,80-1,10$ & $0,25-0,6$ & $0,40 \mathrm{max}$. \\
Tensão Ruptura R & $250-350$ & $400-475$ & $600-750$ \\
[N/mm²] & $98-165$ & $300-375$ & $320-420$ \\
Tensão Escoamento & $200-275$ & $180-240$ & $190-270$ \\
$\mathrm{R}_{\mathrm{p} 0,2}\left[\mathrm{~N} / \mathrm{mm}^{2}\right]$ & Dureza Brinell [HB] & &
\end{tabular}

Fonte - DIN EN 1561, 1997; VDG-MERKBLATT W50, 2002; DIN EN 1563, 2005. 
O ferro fundido cinzento com grafita em forma de lamelas distribuída numa matriz perlítica pode ser produzido com tensão à ruptura de até $350 \mathrm{MPa}$. Para assegurar maior resistência ao desgaste alguns artifícios são aplicados, como a introdução de fósforo ou carbonetos na composição química ou até mesmo o uso do tratamento térmico por indução na superfície de trabalho. A adição de fósforo na composição química do ferro fundido promove 0 aparecimento de um micro constituinte com elevada dureza conhecido como esteadita. Uma alternativa para obter tensão à ruptura acima de $400 \mathrm{MPa}$ é gerar um ferro fundido cinzento com grafitas em forma de lamelas distribuídas numa matriz bainítica (MAHLE, 2010).

A FIG. 12 caracteriza a seção transversal de um ferro fundido cinzento perlítico lamelar por microscopia ótica (MO), sendo possível observar as redes de fosfeto, regiões claras brilhantes, circundadas na seção atacada com Nital 3\%.

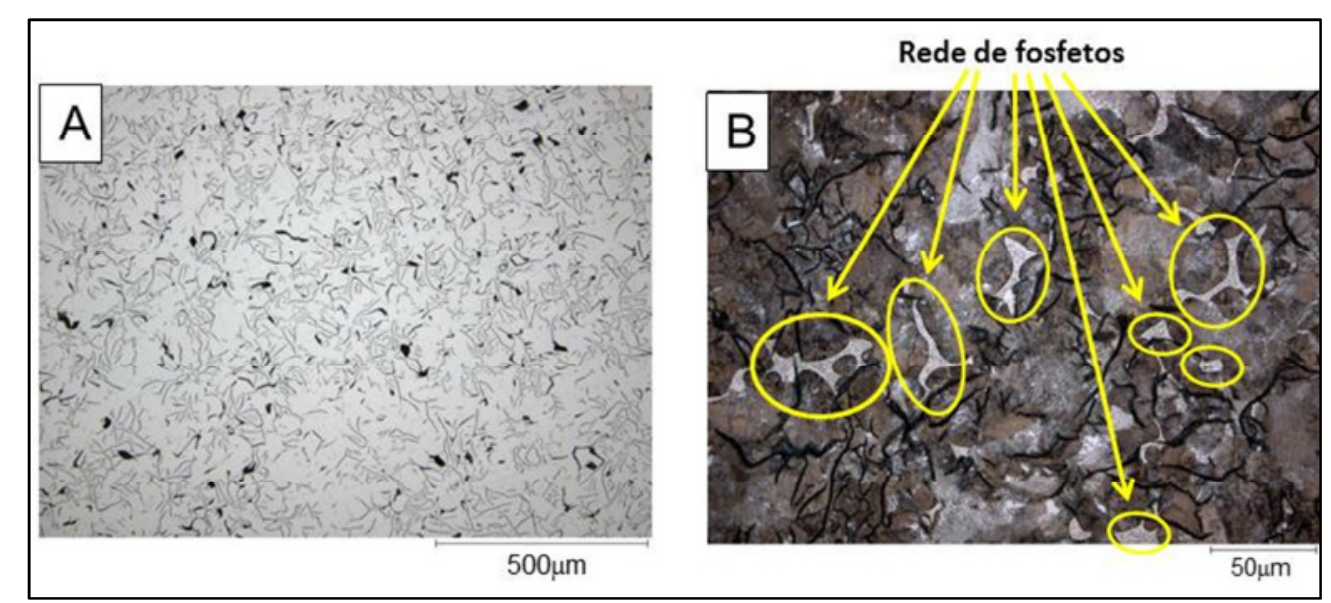

FIGURA 12 - Ferro fundido cinzento lamelar. (A) Microestrutura sem ataque; (B) Microestrutura atacada.

\subsection{Superfície de trabalho em uma camisa de cilindro}

Segundo TOMANIK (1992), a qualidade da superfície interna da camisa de cilindro depende da operação final de usinagem conhecida como brunimento, que é um fator essencial para o bom desempenho do motor assim como da durabilidade dos componentes pistão e anel de pistão. Uma superfície brunida mal acabada pode resultar num excessivo consumo de óleo lubrificante, alto desgaste dos anéis de pistão e levar à ocorrência de engripamento do motor. 


\subsubsection{Brunimento}

O brunimento é um processo de usinagem cuja origem se deu por volta do ano de 1500, quando Leonardo da Vinci esboçou uma máquina para usinagem fina de tubos de madeira. Somente durante as décadas iniciais do século XX surgiram as primeiras máquinas de brunimento denominadas brunidores ou brunidoras, conforme ilustra a FIG. 13. Segundo a norma alemã VDI 3220, o brunimento é caracterizado como: "usinagem com ferramenta abrasiva versátil formada por grãos combinados sob contato constante entre ferramenta e peça, de forma a melhorar a dimensão, forma e superfície de peças pré-usinadas". Entre a ferramenta e a peça ocorre uma mudança de direção do movimento de translação no sentido do comprimento da peça. As superfícies obtidas exibem ranhuras cruzadas (FLORES, 1992).

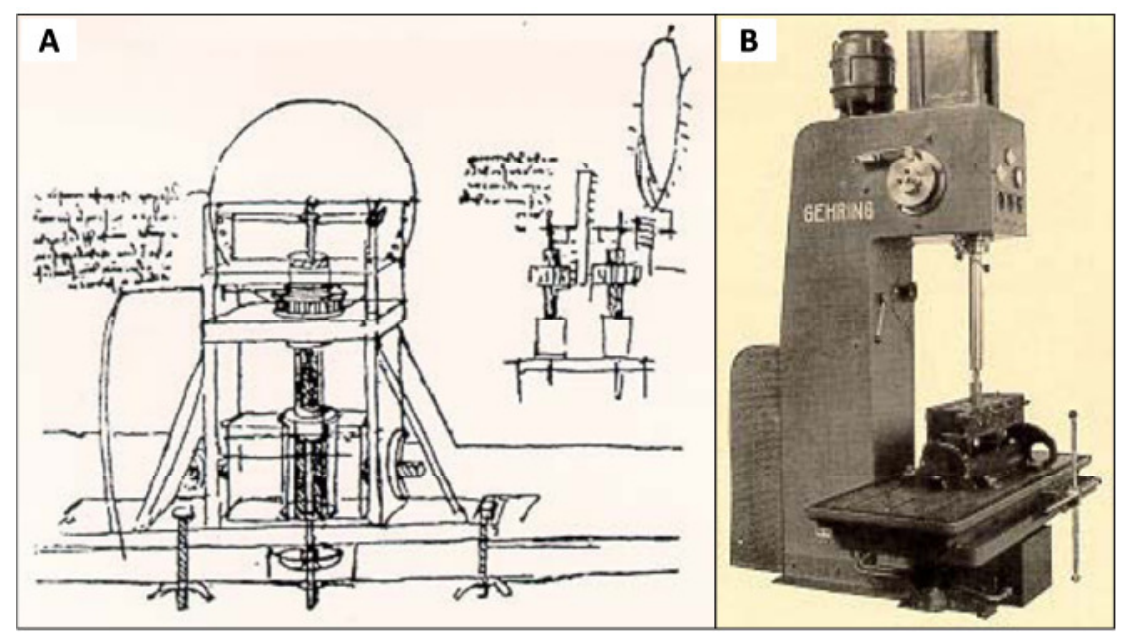

FIGURA 13 - (A) Projeto de máquina de brunimento de Leonardo da

Vinci em 1500; (B) Máquina de brunimento de cilindros desenvolvida pela empresa Gehring, modelo $1 Z$ de 1935 (FLORES, 1992).

De acordo com as normas DIN EN 8589, partes 13 e 14, (2003), o brunimento significa corte com arestas geometricamente indefinidas. As ferramentas multi-arestas têm movimentos que consistem de duas componentes. $O$ brunimento pode ocorrer em fases, utilizando ferramentas de diferentes características, a fim de atender à especificação de rugosidade desejada. A superfície brunida mostra um padrão de ranhuras cruzadas definido, que representa o movimento da ferramenta, criando uma superfície com certa 
texturização. Esse tipo de textura, chamada de estrias cruzadas, é importante para controlar a quantidade desejada de óleo retido para uma determinada aplicação para manter um regime de lubrificação em relação à outra superfície que está em movimento (SOUSA, 2006; NAGEL ${ }^{3}, 2012$ ).

O objetivo da operação de brunimento é aumentar ou diminuir, e controlar a rugosidade em superfícies internas como de furos ou externas. Com o controle da rugosidade, é possível caracterizar a texturização superficial criada pelo processo de brunimento, assim como, qualificar se a quantidade de óleo retido pela superfície brunida está adequada à aplicação (TOMANIK, 1992). Na fabricação de camisas de cilindros, a sequência de usinagem do diâmetro interno nas camisas é tipicamente composta por três operações, isto é, o mandrilamento de desbaste, responsável por retirar a maior quantidade de material para corrigir os erros de forma mais grosseiros provenientes da fundição centrífuga, 0 mandrilamento de semi-acabamento que prepara a superfície para as etapas de brunimento e o acabamento final que usualmente tem três etapas de brunimento, sendo de desbaste, de base e de platô. O ferramental de brunimento utilizado, após ser introduzido no diâmetro interno da camisa, sofre uma expansão radial e em seguida inicia-se o processo de desbaste, conforme ilustra a FIG. 14 (MOCELLIN, 2007).

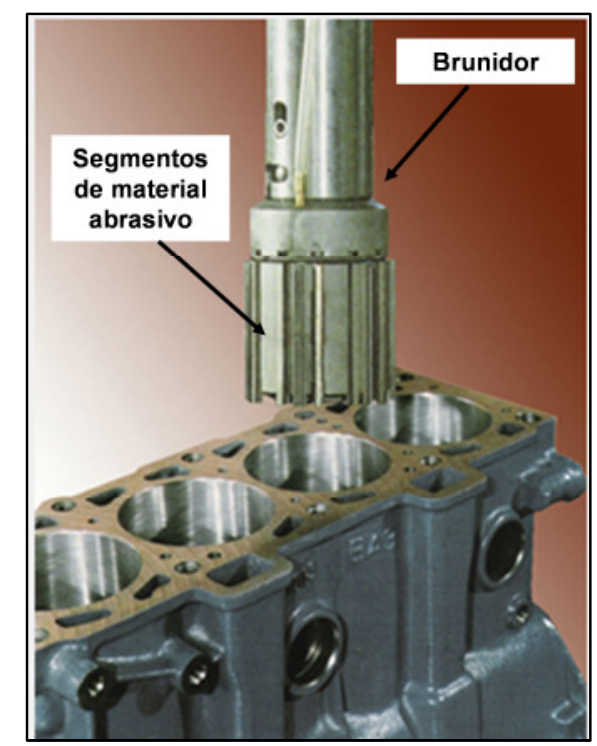

FIGURA 14 - Detalhe da ferramenta de brunir momentos antes de iniciar a etapa de brunimento no bloco de motor (NAGEL, 2012).

\footnotetext{
${ }^{3}$ http://www.nagel.com.br/maquinas_brunimento.asp
} 
Os materiais utilizados nas pastilhas de corte que são montadas na ferramenta de brunimento são: carbeto de silício, óxido de alumínio, nitreto de boro cúbico (CBN) e diamante. Como ligantes são empregados: resinas sintéticas, ligantes metálicos e ligantes cerâmicos. (NAGEL, 2012).

Segundo UEHARA (2007), uma superfície brunida de má qualidade pode significar um maior consumo de óleo do motor, acelerar a taxa de desgaste dos anéis de pistão assim como causar engripamento do motor pelo fato de não proporcionar um filme de óleo adequado e, portanto um regime de lubrificação apropriado entre anel de pistão e superfície de trabalho da camisa de cilindro.

\subsection{2 Ângulo de brunimento}

De acordo com HEYWOOD (1988), as características do brunimento como nível de rugosidade, ângulo de cruzamento das estrias e qualidade da superfície brunida podem influenciar no atrito do motor, assim como na durabilidade dos componentes que deslizam em contato, como o pistão e os anéis de pistão.

O ângulo de brunimento é determinado pelo movimento vertical e rotacional da ferramenta de brunimento, iniciado pela usinagem dos cantos vivos presentes na pastilha de brunimento. O ângulo de brunimento pode ser medido diretamente na superfície ou pela técnica da réplica de superfície, também conhecida como impressão de "fax-film", conforme ilustra a FIG. 15. A técnica de "fax-film" abordada em detalhes no item a seguir 3.7.3 (TOMANIK, 1992; KÖHLER e FLIERL, 2006).

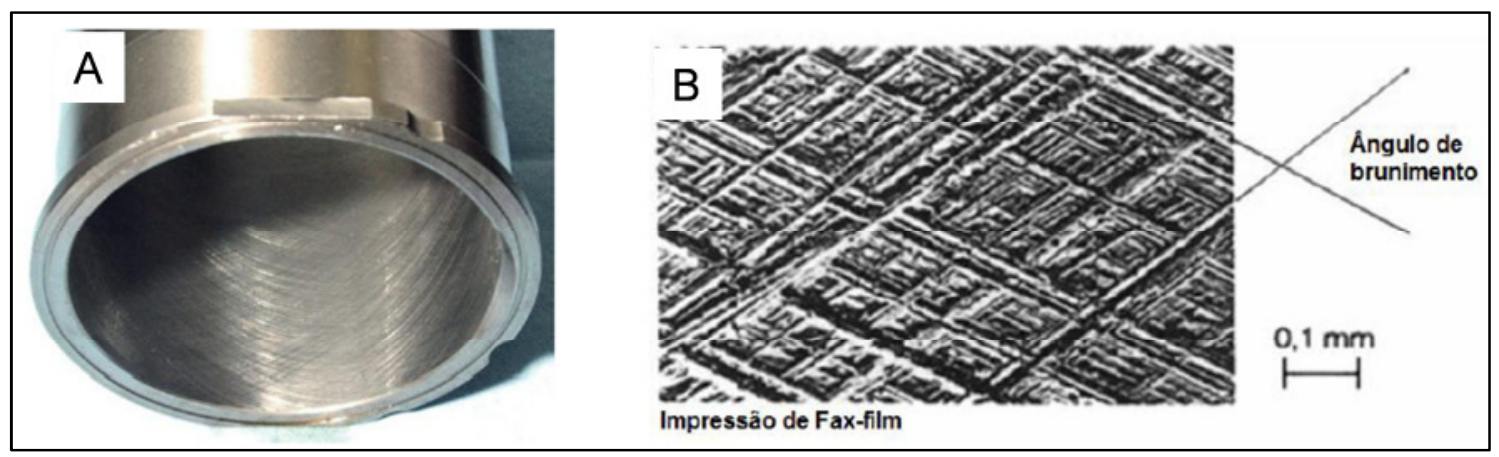

FIGURA 15 - (A) Camisa de cilindro molhada após brunimento; (B) resultado da réplica da superfície brunida (KÖHLER e FLIERL, 2006). 


\subsubsection{Técnicas de medição e parâmetros de controle em superfícies brunidas}

Muitos parâmetros podem ser utilizados para caracterizar a rugosidade de uma superfície brunida, sendo possível gerar valores e interpretações diferentes, dependendo do tipo de parâmetro aplicado (TOMANIK, 1992; UEHARA, 2007). Os principais parâmetros de rugosidade serão abordados neste capitulo, porém maiores detalhes podem ser encontrados em normas específicas que tratam do assunto de controle de superfícies, como ANSI/ASME B46 (1995) e DIN EN ISO 13565, parte 2, (1998). O gráfico do perfil da rugosidade em duas dimensões é gerado pelo instrumento de medição que entra em contato com a superfície e se movimenta em linha, reproduzindo características de um comprimento da superfície. O perfil de rugosidade é gerado em função da altura entre os vales e dos picos do comprimento da superfície analisado. Embora muito útil para visualizar as características de uma superfície acabada, esses gráficos precisam ser analisados com cuidado, uma vez que o perfil real se apresenta com distorções de ampliação e, portanto deformado (HUTCHINGS, 1992). Tipicamente, a escala do eixo vertical do gráfico de rugosidade apresenta uma ampliação maior do que a do eixo horizontal, conforme ilustram as FIG. 16 e 17.

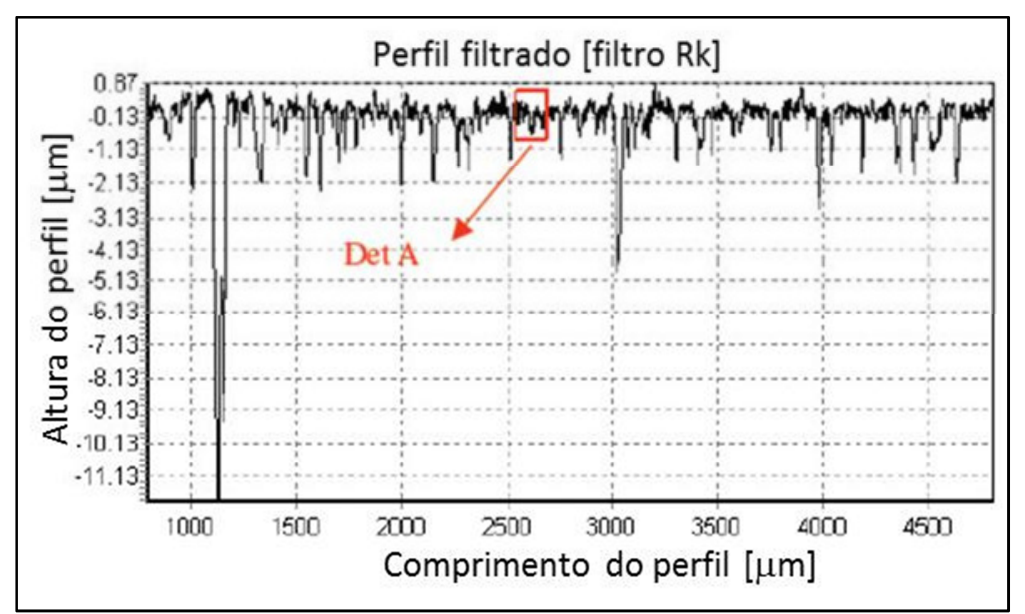

FIGURA 16 - Perfil de superfície rugosa obtido por equipamento de medição (UEHARA, 2007). 


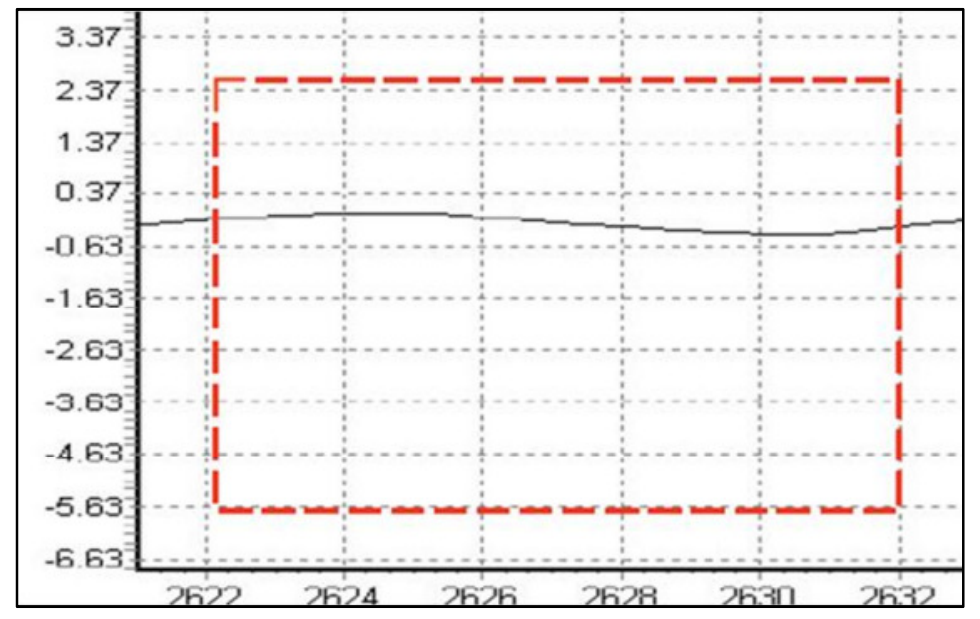

FIGURA 17 - Detalhe "A" da FIG. 20 ilustrando a deformação quando se aplica a mesma ampliação nos eixos do gráfico do perfil (UEHARA, 2007).

Atualmente, análises da superfície rugosa em três dimensões são utilizadas, principalmente em motores mais avançados, para uma medição mais apurada, que resulta na análise de uma pequena área da superfície, tendo como consequência a introdução de novos parâmetros de medição, como quantidade de material dobrado e porosidade, que não podem ser reproduzidos pelas análises convencionais em duas dimensões (LEMKE et al., 2003). A FIG. 18 mostra um exemplo de análise em três dimensões feito por equipamento com perfilômetro ótico de luz branca, também conhecido como WLI "White Light Interferometer", que faz a medição sem contato com a superfície rugosa.

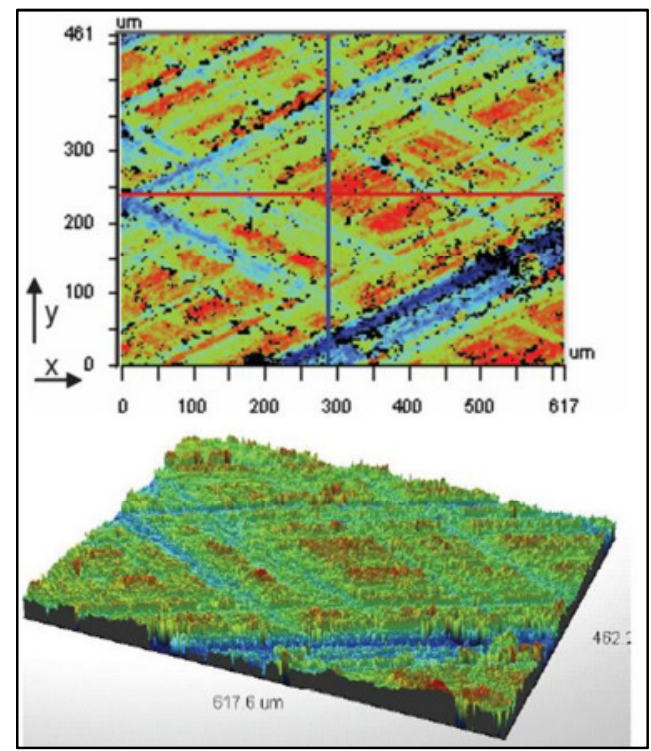

FIGURA 18 - Perfil rugoso gerado por WLI (TOMANIK, 2005). 
De acordo com a TAB. 2, existem vantagens e desvantagem entre as diferentes técnicas de medição da rugosidade em uma superfície brunida. Tipicamente, o método de controle mecânico "Stylus" confere um perfil de medição em dois eixos, ou seja, 2-D. Em contraste com este método, imagens com diferentes tonalidades de cinza e imagens de perfilômetros óticos geram informações tridimensionais, 3-D, que auxiliam na identificação dos vales e picos.

TABELA 2 - Comparação entre os métodos de medição de rugosidade.

\begin{tabular}{lccc}
\hline & $\begin{array}{c}\text { Mecânico } \\
\text { "Stylus" }\end{array}$ & $\begin{array}{c}\text { Imagem com } \\
\text { tonalidade de } \\
\text { cinza }\end{array}$ & $\begin{array}{c}\text { Imagem de } \\
\text { perfilômetro } \\
\text { ótico }\end{array}$ \\
\hline $\begin{array}{l}\text { Região medida } \\
\text { Informação de profundidade }\end{array}$ & Sim & 2D & 3D \\
$\begin{array}{l}\text { Informação de defeitos } \\
\text { geométricos }\end{array}$ & Não & Não & Sim \\
$\begin{array}{l}\text { Análise de toda superfície } \\
\text { brunida }\end{array}$ & Consome & Sim & Possível, com \\
$\begin{array}{l}\text { Gastos com processamento } \\
\text { computacional }\end{array}$ & Buito tempo & razoável esforço & Consome muito \\
$\begin{array}{l}\text { Medição sem contato } \\
\text { Normalização dos }\end{array}$ & Não & Alto & tempo \\
parâmetros & Sim & Sim & Alto \\
\hline
\end{tabular}

Fonte - LEÓN, 2002.

Algumas características podem ser visualizadas por uma cuidadosa inspeção visual ou preferencialmente pela técnica da réplica da superfície, "fax film", com auxílio de microscópio ótico (TOMANIK, 1992).

O "fax-film" é o mais difundido entre os fabricantes de motores devido à praticidade e baixo custo. A réplica é obtida por intermédio de um filme de acetato, que após uma cuidadosa limpeza da superfície brunida da camisa, é pressionado sobre esta superfície, juntamente com a aplicação de acetona. A acetona reage espontaneamente com o filme de acetado, que se deforma tomando como referência a rugosidade da superfície recoberta. Após a evaporação da acetona, o acetato assume a mesma rugosidade da superfície recoberta, se tornando uma réplica da mesma. A seguir o acetato é removido e a impressão da superfície pode ser examinada, geralmente com auxílio de um microscópio ótico (MO) (UEHARA, 2007; TOMANIK, 2008). Por este método, 
avalia-se o ângulo de brunimento e se observa a integridade da superfície em relação à qualidade dos riscos e à presença de falhas (SOUSA, 2006).

Contudo, em se tratando de superfícies brunidas, é importante levar em consideração algumas peculiaridades que podem estar presentes na textura do brunimento, sendo essas inerentes ao processo de brunimento. Tais peculiaridades podem ser o próprio ângulo de brunimento, a presença de material dobrado, a interrupção dos canais de óleo, existência de canais não homogêneos, porosidades, partícula estranha e material arrastado ou amassado, conforme a FIG. 19, que ilustra resultados de análise de uma mesma superfície brunida pela técnica do "fax film" com auxílio do MO e por microscopia eletrônica de varredura (MEV) (LEÓN, 2002).

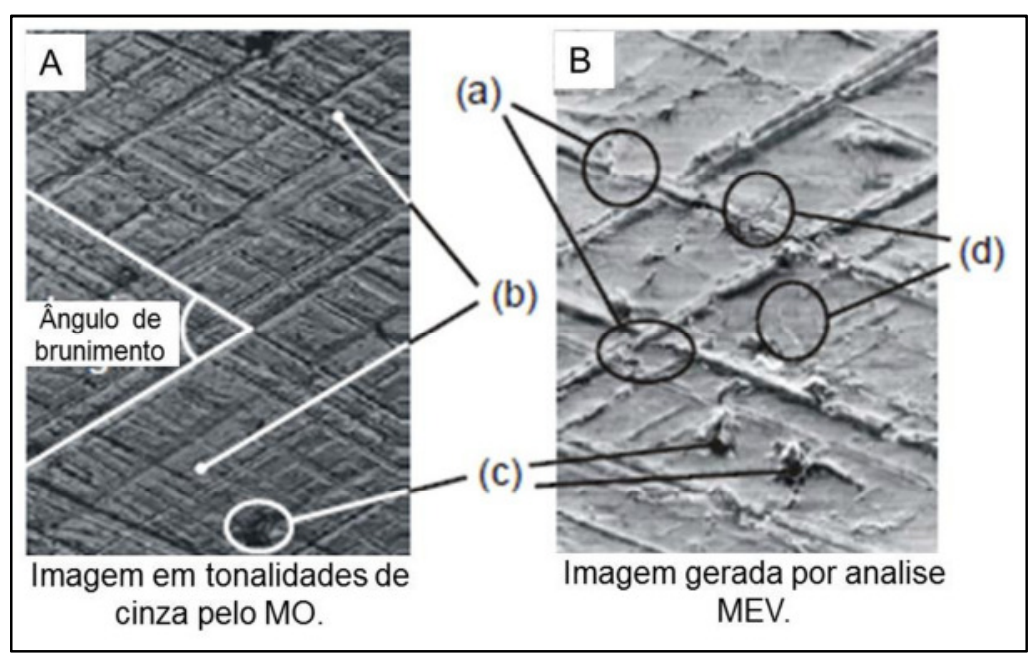

FIGURA 19 - Análise de superfície brunida (A) por MO e em (B) por MEV, onde (a) manchas na superfície e ranhuras interrompidas; (b) padrão das ranhuras; (c) porosidade ou partículas estranhas (d), material arrastado ou amassado. (LEÓN, 2002).

Uma das mais importantes propriedades de uma superfície usinada são os parâmetros de rugosidade. O parâmetro $\mathrm{Ra}$, ou média aritmética da rugosidade, é o mais usualmente aplicado em superfícies usinadas, como por exemplo, retífica e ou lapidação (TABENKIN, 2004). Este parâmetro basicamente reflete a altura média das irregularidades observadas na superfície, a partir de uma linha de referência em um dado comprimento. O parâmetro Ra é um valor para decisões de aprovar ou reprovar, porém, no caso de superfícies 
multifuncionais como são as superfícies brunidas, não é capaz de dizer se a superfície está com a quantidade de picos e riscos suficientes para retenção de óleo, conforme ilustra a FIG. 20 (LEÓN, 2002; UEHAHA, 2007).

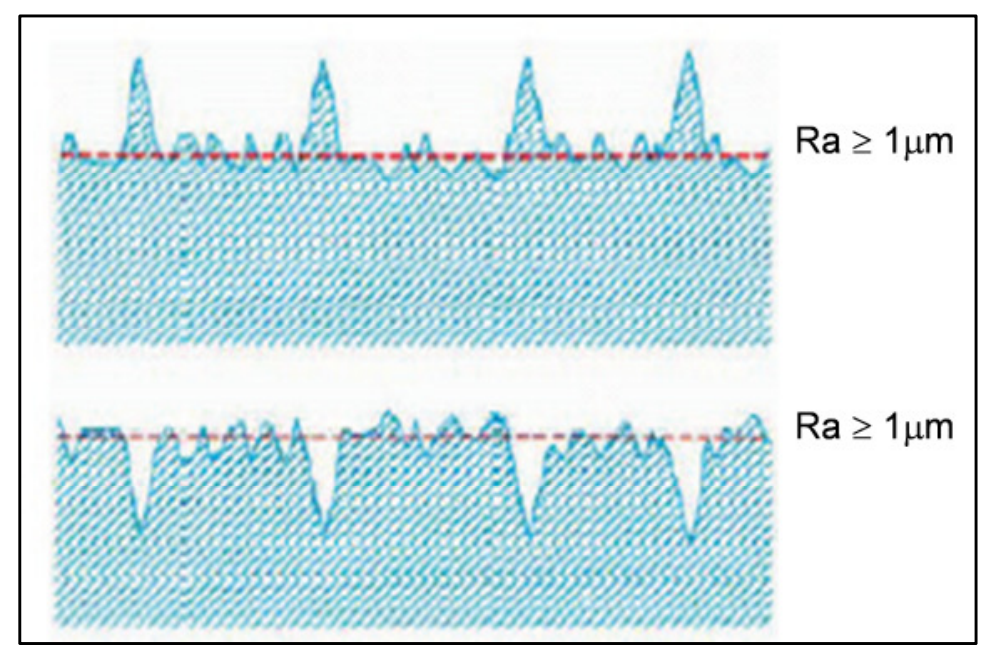

FIGURA 20 - Valores similares de $\mathrm{Ra}$ em superfícies rugosas diferentes (UEHARA, 2007).

Outros dois parâmetros de rugosidade muito utilizados são o Rmax e o Rz. O parâmetro Rmax mede a distância vertical do pico mais elevado até o vale mais profundo em cinco trechos distintos da superfície rugosa em um comprimento pré-estabelecido. A partir dos cinco valores obtidos, seleciona-se o valor de Rmax mais elevado. Este parâmetro é muito sensível a anomalias como riscos e partículas contaminantes que podem estar presentes na superfície (TABENKIN, 2004).

De acordo com a norma ABNT NBR ISO 4287 (2002), o parâmetro Rz é também baseado numa análise de cinco medições com comprimentos préestabelecidos, porém ao invés de escolher o valor maior entre pico e vale se calcula a média dos cinco valores registrados.

Superfícies que demandam múltiplas funções para garantir alto desempenho, como é o caso da superfície de uma camisa de cilindro, requerem superfícies de baixa rugosidade e bem controladas. No exemplo de camisas de cilindro, a superfície brunida precisa contribuir para uma boa vedação quando em contato com os anéis de pistão do motor e ao mesmo tempo ser capaz de suprir um filme de óleo adequado, proveniente dos vales da texturização de brunimento, 
para manter um regime de lubrificação dos anéis, principalmente nas regiões de reversão de sentido que são locais onde os anéis apresentam velocidades de deslizamento tendendo a zero e que, portanto, tem a tendência de romper o filme de óleo (LEÓN, 2002; UEHARA, 2007). Para atender a esta complexa função da superfície, normas foram desenvolvidas para estabelecer parâmetros de rugosidade, como os da série Rk. Dentro da série Rk, os parâmetros Rpk e Rvk são definidos com base no gráfico da função de densidades de picos e vales, também conhecido como "Materials Rate Curve" ou curva de fração de contato, também denominada de "Abbott-Firestone Curve", que indica a quantidade de material Mr em relação ao nível de corte, profundidade de perfil (DIN EN ISO 13565-1, 1998; DIN EN ISO 13565-2, 1998).

A experiência tem mostrado que a curva "Abbott-Firestone", utilizada para revelar as características da rugosidade da camisa brunida, é uma boa ferramenta para definir informações importantes sobre a superfície brunida. A partir de um comprimento pré-estabelecido, a norma DIN EN ISO 13565-2 (1998) define os conceitos dos parâmetros da família Rk, assim como os valores de porcentagem de área de contato, ou densidade de material, Mr1 e Mr2 (TOMANIK, 1992). A FIG. 21 ilustra detalhes da curva de Abbott-Firestone e como os parâmetros da série Rk se apresentam em relação a uma superfície rugosa.

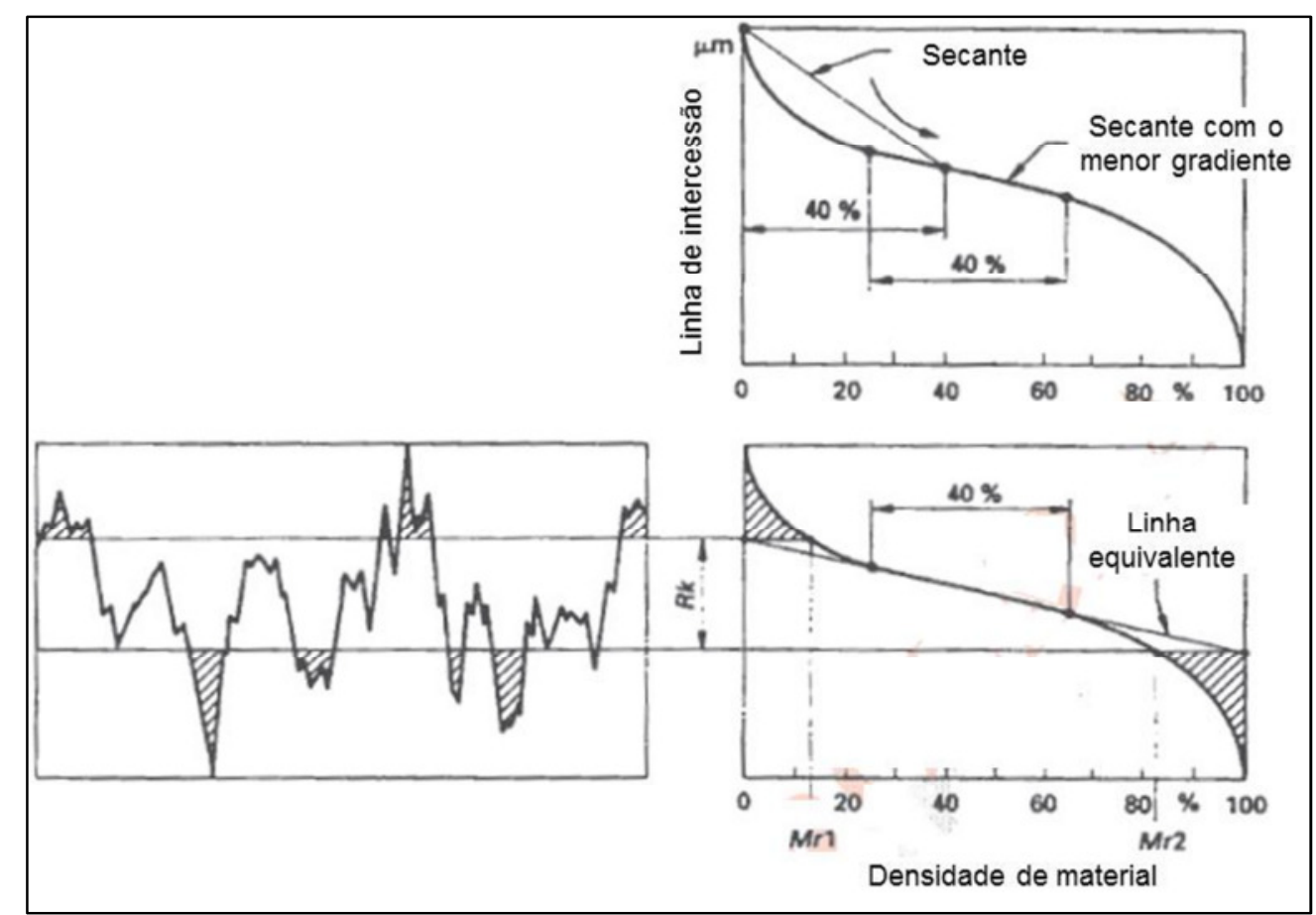

FIGURA 21 - Parâmetros da série Rk (DIN EN ISO 13565-2, 1998). 
Para determinar os parâmetros Rpk e Rvk é necessário determinar primeiramente o parâmetro $\mathrm{Rk}$, que é obtido através da construção de uma linha equivalente na região central na curva de Abbott-Firestone. A linha equivalente compreende $40 \%$ do perfil rugoso medido e intercepta as abcissas $\mathrm{Mr}=0 \% \mathrm{e} \mathrm{Mr}$ $=100 \%$, conforme indicado na FIG. 21. A região de $40 \%$ na linha equivalente é definida quando a linha secante da curva de Abbott-Firestone tem o menor coeficiente angular, ou seja, mais próximo da condição horizontal. Esta determinação é possível de ser feita movimentando a linha secante no intervalo $\Delta \mathrm{Mr}=40 \%$ ao longo da curva de Abbott-Firestone, começando em $\mathrm{Mr}=0 \%$.

Quando a linha secante apresenta menor coeficiente angular, estabelece-se então uma região central da curva a partir da qual, a linha é estendida até as abcissas do gráfico. O índice central Rk é obtido medindo a distância entre os pontos de intercessão com a ordenada, conforme apresentado na FIG. 21.

Os parâmetros Rpk e Rvk (FIG. 21) são as cotas verticais dos picos e vales presentes, respectivamente, calculados como a altura do cateto vertical do triângulo-retângulo construído, e possuindo a mesma área de picos ou de vales. Outra forma de se evitar picos e vales maiores que não são muito representativos do perfil é descartar do gráfico do perfil da superfície, de 0 a $2 \%$ e 98 a 100\% (DIN EN ISO 13565-2, 1998).

A área medida do triângulo retângulo formado conforme desenho da FIG. 21 equivale ao valor Mr1, e para outra extremidade se obtém Mr2. Mr é o parâmetro que descreve a densidade de material em percentual. É dividido então em três partes distintas, descrevendo os picos (Rpk), os vales (Rvk) e a parte central do perfil de rugosidade (Rk). As definições individuais de cada parâmetro da série $\mathrm{Rk}$ e respectivas recomendações são apresentadas na TAB. 3. 
TABELA 3 - Definição dos parâmetros da série Rk.

\begin{tabular}{|c|c|c|}
\hline Parâmetro & Descrição & Efeito na aplicação \\
\hline Rpk & $\begin{array}{l}\text { Altura do pico } \\
\text { reduzida }\end{array}$ & $\begin{array}{l}\text { Picos acima da faixa da rugosidade central (Rk) } \\
\text { aumenta o período de amaciamento do motor } \\
\text { podendo gerar alto desgaste. }\end{array}$ \\
\hline Rk & $\begin{array}{l}\text { Rugosidade } \\
\text { central }\end{array}$ & $\begin{array}{l}\text { A rugosidade central determina o consumo de } \\
\text { óleo. Quanto menor a rugosidade central, } \\
\text { menor o consumo de óleo. }\end{array}$ \\
\hline Rvk & $\begin{array}{l}\text { Profundidade do } \\
\text { vale reduzida }\end{array}$ & $\begin{array}{l}\text { Os vales foram os reservatórios de óleo. Um } \\
\text { valor de Rvk muito baixo pode levar em longo } \\
\text { prazo um alto consumo de óleo. }\end{array}$ \\
\hline Mr1 & $\begin{array}{l}\text { Fração de material } \\
\text { dos picos } \\
\text { protuberantes }\end{array}$ & $\begin{array}{l}\text { Para obter o curto período de quebra de picos } \\
\text { no inicio de funcionamento do motor, um baixo } \\
\text { Mr1 deve ser objetivado. }\end{array}$ \\
\hline Mr2 & $\begin{array}{c}\text { Fração de material } \\
\text { da profundidade } \\
\text { da rugosidade } \\
\text { central }\end{array}$ & $\begin{array}{l}\text { Junto com o Rvk, eles representam a dimensão } \\
\text { da capacidade do volume de óleo. }\end{array}$ \\
\hline $\begin{array}{l}\text { Ângulo de } \\
\text { brunimento }\end{array}$ & $\begin{array}{l}\text { Define a } \\
\text { orientação dos } \\
\text { canais de óleo. }\end{array}$ & $\begin{array}{l}\text { Distribui o óleo na superfície brunida da } \\
\text { camisa. }\end{array}$ \\
\hline
\end{tabular}

Fonte - UEHARA, 2007.

\subsubsection{Tipos de brunimento}

No passado, superfícies com brunimento convencional conhecido como "Standard honing" e o brunimento platô conhecido como "Plateau honing", que recentemente se tornou obsoleto, foram os mais utilizados em camisas de cilindro. Contudo, nos últimos anos, muitos estudos foram divulgados no intuito de promover superfícies brunidas mais lisas. A recomendação de superfícies com brunimento mais liso surgiu como solução para reduzir o tempo de quebra dos picos da superfície da camisa de cilindro no inicio de vida do motor, também conhecido como período de amaciamento, afetando de forma benéfica a redução do atrito dos anéis de pistão assim como uma favorável contribuição na redução no consumo de óleo (UEHARA, 2007; AKALIN et al., 2008). Alinhado à necessidade de reduzir a rugosidade da superfície brunida, os processos de 
brunimento evoluíram no sentido de diminuir os valores dos parâmetros Rpk e Rk, porém mantendo o compromisso de garantir reservatórios de óleo (Rvk) adequados conforme a necessidade do funcionamento dos anéis de pistão, UEHARA (2007).

As principais tecnologias de brunimento utilizadas e em uso atualmente podem ser vistas na FIG. 22, onde se buscou correlacionar superfícies brunidas a partir de diferentes processos de usinagem com os típicos parâmetros de rugosidade da série Rk medidos. Para melhor visualização e entendimento, os valores da série Rk são dispostos num gráfico de barras onde a porção dos parâmetros Rpk e metade do Rk se encontram sobrepostos na região positiva do gráfico e a porção da outra metade de Rk e do Rvk estão sobrepostos na parte negativa do gráfico.

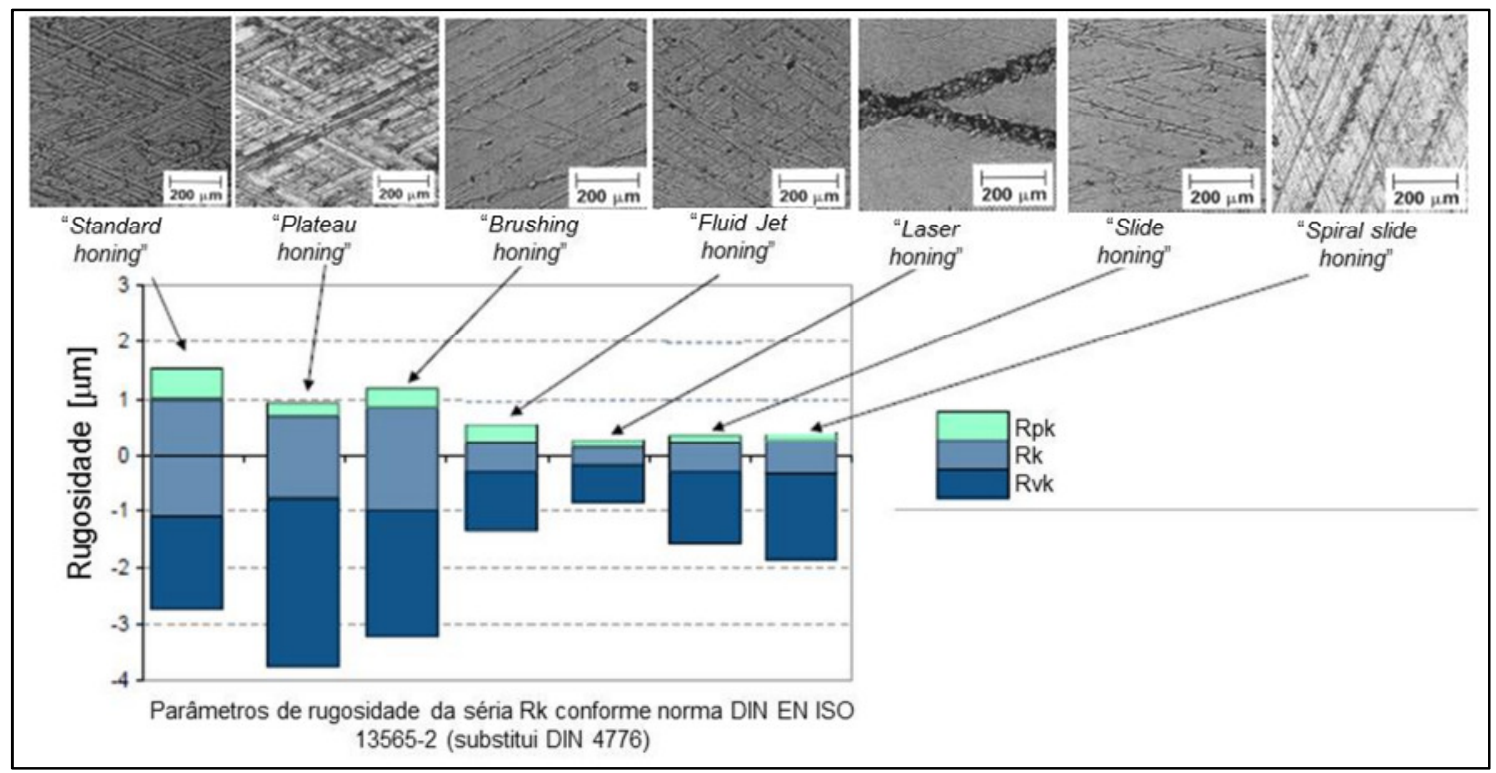

FIGURA 22 - Tipos de brunimento em cilindros (TOMANIK, 2005).

O "Standard honing", muito utilizado no passado pelo fato de apresentar um padrão de texturização adequado para a época e de baixo custo, consistia em duas etapas de brunimento. É possível observar na FIG. 22 que as porções dos parâmetros Rpk e Rk são superiores em relação aos outros tipos de brunimento. Nota-se que a porção do parâmetro Rvk é similar ou até menor do que a porção representada pelo parâmetro $R k$, características essas, adequadas para os níveis de emissão e desempenho dos motores no passado. 
O "Plateau honing" apresenta uma tendência de redução nas porções dos parâmetros Rpk e Rk e aumento na porção do parâmetro Rvk. Este tipo de brunimento usualmente é realizado em três etapas, sendo a terceira responsável pela remoção dos picos da superfície rugosa gerados nas etapas anteriores. Este tipo de perfil rugosa reduz o tempo de amaciamento do motor. A porção do parâmetro Rvk mais extensa promove vales mais profundos na rugosidade favorecendo os reservatórios de óleo que garantem um filme de óleo adequado para funcionamento dos anéis de pistão, principalmente nos intervalos de funcionamento do motor. Entretanto, se percebe que a porção Rk ainda é elevada o que o torna não adequado as demandas de mercado e, portanto, obsoleto.

O brunimento escovado, também conhecido como "Brushing honing", é similar ao brunimento platô, realizado em três etapas de brunimento, entretanto, na terceira etapa ocorre um escovamento da superfície por intermédio de uma ferramenta impregnada de material abrasivo à base de carbeto de silício ou de alumínio (FLEX-HONE, 2011). O escovamento não tem o mesmo poder de corte e remoção de material, entretanto, espera-se desta operação uma remoção de pequenas partículas, que geralmente permanecem impregnadas nos vales da texturização brunida, para minimizar problemas de desgaste localizado do cilindro. Na FIG. 22 nota-se que o brunimento escovado tem uma tendência de apresentar valores de Rk pouco acima do brunimento platô e portanto oferece desempenho de motor similar.

O brunimento por jato d'água também conhecido como "fluid jet honing" utiliza um jato de água de alta pressão, aproximadamente 120 bar, na terceira etapa de brunimento. Durante a ação do jato de água sobre a superfície brunida, o material dobrado e as partículas impregnadas na superfície são removidos. A força do jato cria pequenos bolsões ou poros a partir da quebra de partículas duras na microestrutura do ferro fundido, que vão contribuir posteriormente para a formação de reservatórios de óleo. Numa quarta etapa de brunimento, os picos da rugosidade são removidos obtendo-se uma especificação de superfície lisa.

O brunimento por laser, também conhecido como "Laser honing", apresenta uma superfície de baixa rugosidade após as primeiras etapas de brunimento que posteriormente recebe uma usinagem por laser que gera determinada texturização. O uso do laser é para favorecer a criação de reservatórios de óleo e em função da alta tecnologia disponível, é possível 
controlar a forma dimensional desses reservatórios. Após a usinagem pelo laser, uma quarta operação de brunimento é necessária para remover o excesso de material, como por exemplo, rebarbas resultantes da usinagem por laser. Muitas variações deste tipo de brunimento são encontradas e a região a receber a texturização por laser pode ser variada ao longo da superfície de trabalho da camisa de cilindro. A FIG. 23 ilustra um tipo de superfície que recebeu este tipo de brunimento somente na região TDC.

O brunimento deslizante, também conhecido como "Slide honing", é uma evolução do "Plateau honing". Este tipo de brunimento também é realizado em três etapas sendo a terceira responsável pela geração da baixa rugosidade com auxílio de ferramentas multi-arestas com pastilhas de corte impregnadas com diamante, ou cerâmica de alta qualidade. De acordo com a FIG. 22, a porção do parâmetro Rpk é bem reduzida, o que favorece na diminuição do tempo de amaciamento do motor. $\mathrm{O}$ ângulo de brunimento típico encontrado varia de $30 \mathrm{a}$ 60 graus, tomando como referência uma linha horizontal, perpendicular ao comprimento da camisa.

O brunimento espiral deslizante, também conhecido como "Spiral slide honing" apresenta parâmetros da série Rk semelhantes ao "Slide honing", porém com ângulo de brunimento maior, ao redor de 135 graus. Conforme a FIG. 22, se observa que a textura apresenta ranhuras mais verticais. $O$ maior ângulo de brunimento pode favorecer na questão de evitar o engripamento dos anéis e quando combinado com uma baixa rugosidade, reduzir o consumo de óleo (UEHARA, 2007).

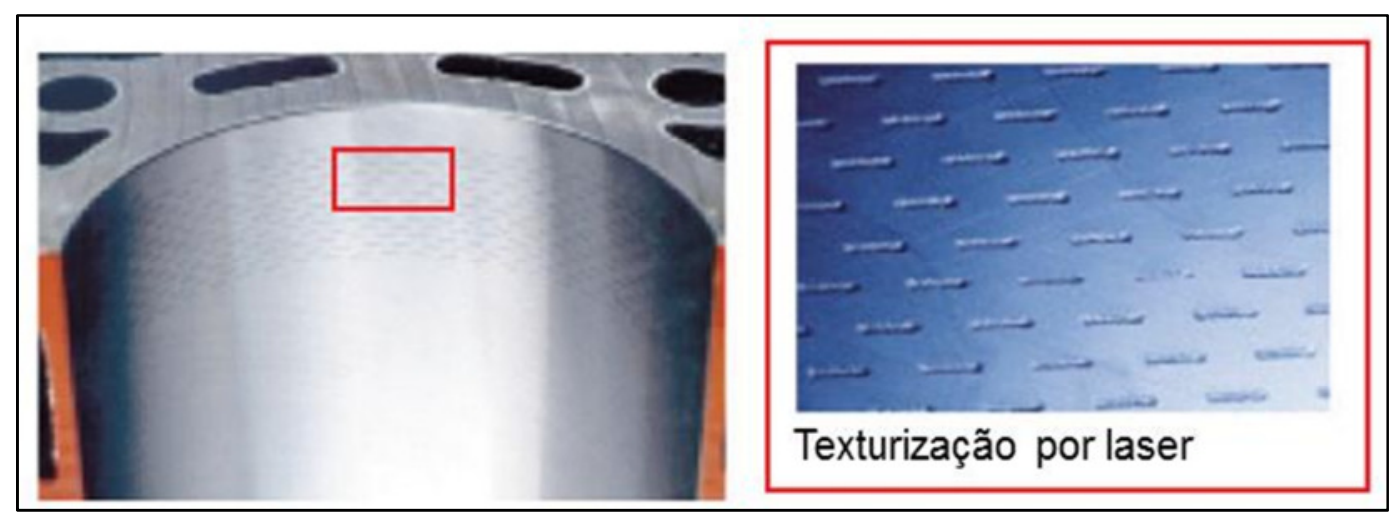

FIGURA 23 - Brunimento por laser na região TDC (GEHRING, 2012). 
Levando em consideração os materiais abrasivos mais utilizados atualmente no processo de brunimento, a TAB. 4 busca ilustrar para cada tipo de brunimento, a sequência de operações na manufatura.

TABELA 4 - Etapas de usinagem no brunimento e materiais abrasivos.

\begin{tabular}{cccccc}
\hline $\begin{array}{c}\text { Tipo de } \\
\text { brunimento }\end{array}$ & Versões & $1^{\text {a }}$ etapa & $2^{\text {a }}$ etapa & 3ª etapa & 4 ${ }^{\text {a }}$ etapa \\
\hline $\begin{array}{c}\text { Standard } \\
\text { honing" }\end{array}$ & 1 & Diamante & Diamante & & \\
& 3 & Diamante & CBN & & \\
\hline "Plateau honing" & 1 & Diamante & Diamante & Diamante & \\
& 2 & Diamante & Diamante & CBN & \\
\hline "Brushing honing" & 1 & Diamante & Diamante & Escovamento & \\
& 2 & Diamante & CBN & Escovamento & \\
\hline "Fluid Jet honing" & & Diamante & Diamante & Jato d'água & CBN \\
\hline "Laser honing" & 1 & Diamante & Laser & CBN & CBN \\
& 2 & Diamante & CBN & Laser & CBN \\
\hline "Slide honing" e & 1 & Diamante & Diamante & Diamante & \\
"Spiral slide & 2 & Diamante & Diamante & CBN & \\
honing" & 3 & Diamante & CBN & CBN & \\
\hline
\end{tabular}

Fonte - MAHLE, 2012.

\subsection{Atrito gerado pelo contato dos anéis de pistão na camisa de cilindro}

Segundo ANDERSSON et al. (2002), o deslizamento entre os anéis do pistão e o cilindro está sujeito a diferentes mecanismos de atrito durante um ciclo térmico de trabalho do motor. Devido às variações de carga, velocidade e estado da superfície de contato do cilindro, as condições de lubrificação entre o anel e o cilindro são extremamente transientes, e refletem na variação do coeficiente de atrito e no comportamento em relação ao desgaste. $O$ atrito do anel é determinado pela carga aplicada sobre o mesmo. As propriedades da superfície de contato e as condições de lubrificação são determinadas pela velocidade de deslizamento, viscosidade do óleo e espessura do filme de óleo presente na interface de contato. A carga sobre o anel é gerada pela tensão de confinamento 
no cilindro (força tangencial) e pela força normal decorrente da pressão dos gases atuando na parte traseira do anel (diâmetro interno) dentro da canaleta do pistão.

Os mecanismos de atrito atuantes entre os anéis de pistão e o cilindro durante o funcionamento do motor incluem uma combinação de lubrificação limite e mista, no ponto morto inferior e superior do mecanismo biela-manivela, enquanto no meio-curso de funcionamento do pistão apresentam um comportamento hidrodinâmico de lubrificação. O coeficiente máximo de atrito, 0 qual ocorre sob condições de lubrificação mista nas regiões próximas aos pontos de reversão superior e inferior do pistão, pode ser reduzido com uma menor rugosidade na superfície interna do cilindro ou com o aumento da viscosidade do óleo lubrificante, enquanto que a pressão de atrito, influenciada fortemente pela velocidade e deslocamento do pistão, ocorre sob condições de lubrificação hidrodinâmica presente entre o ponto morto superior e o inferior do cilindro, tende a ser maior com o aumento da viscosidade do óleo lubrificante utilizado (SATO et al., 2004; ANDERSSON et al., 2002).

Já faz quase 100 anos desde que o conhecido Richard Stribeck concluiu seus experimentos sobre atrito em mancais de escora planos. Os resultados desses testes foram subsequentemente reordenados por Ludwig Gumbel. Os dados têm sido amplamente representados no que se tornou conhecido como o diagrama Stribeck, como forma de plotar duas grandezas adimensionais agrupadas. Neste gráfico, o coeficiente de atrito $(\mu)$ é posicionado na ordenada e a variação do número de Sommerfeld (viscosidade do óleo $\mathrm{x}$ velocidade / carregamento específico). Com o desenvolvimento do entendimento dos regimes de lubrificação, incorporou-se neste gráfico a taxa do filme de óleo ( $\lambda$ ) na abcissa conforme o diagrama modificado de Stribeck na FIG. 27 (HEYWOOD, 1988; TAYLOR, 1998; PRIEST, 2000).

O coeficiente $\lambda$ na FIG. 24 é calculado pela aplicação da análise clássica de filmes finos, assumindo a partir de uma superfície lisa até uma superfície rugosa. Valores apropriados da espessura média do filme de óleo que definem os diferentes regimes de lubrificação são frequentemente confrontados. Por outro lado, para o sistema anel de pistão-camisa de cilindro, a determinação da posição é complexa por muitos fatores, incluindo o reconhecimento de que a rugosidade medida em laboratório pode ser modificada durante o funcionamento 
do motor o que resulta num efeito de amaciamento, ou quebra dos picos da superfície rugosa.

O anel de pistão é provavelmente o componente de motor mais complicado no campo da tribologia. Por ser reconhecido como um componente sujeito a variações rápidas de carregamento, velocidade, temperatura e lubrificação, é também conhecido por trabalhar em vários regimes de lubrificação, incluindo o regime limite em um único curso do pistão. Da mesma forma, para os mancais que também enfrentam regimes de lubrificação diferenciados, incluindo o regime elasto-hidrodinâmico, em função da carga aplicada e da rotação do eixo em contato (PRIEST, 2000).

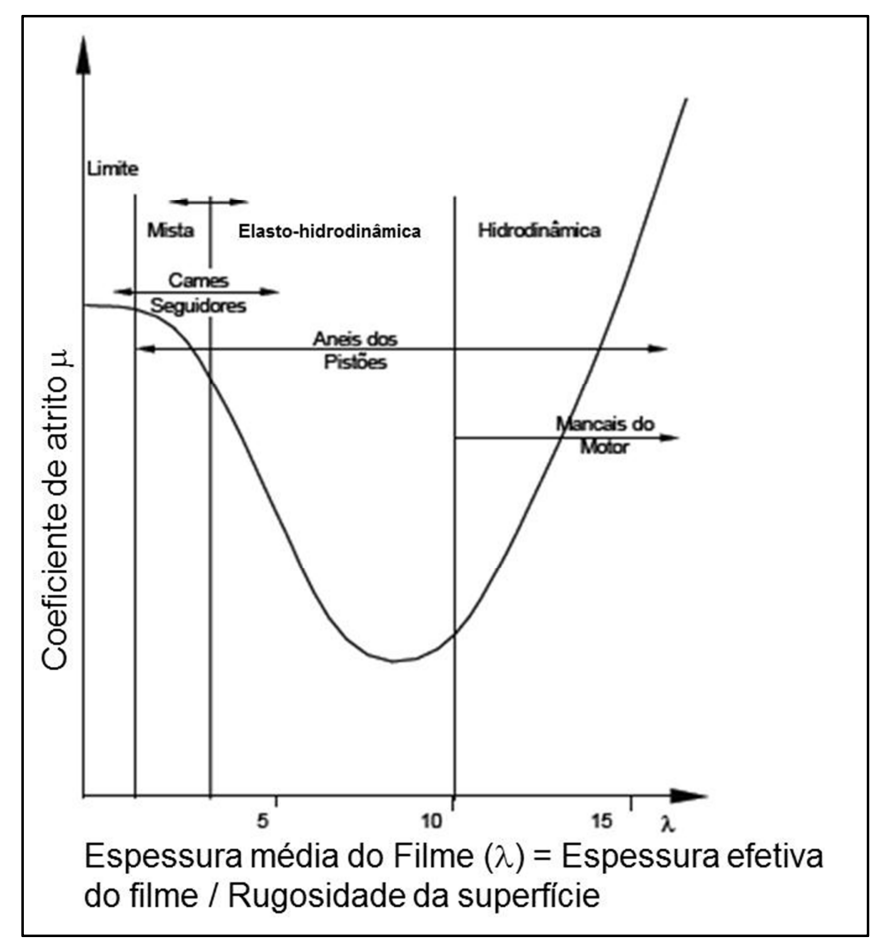

FIGURA 24 - Diagrama modificado de Stribeck mostrando os regimes, modo e forma de lubrificação para componentes de motor (TAYLOR, 1998; PRIEST, 2000).

Os regimes de lubrificação indicados na FIG 24 são explicados de forma breve na TAB. 5. Os regimes de lubrificação convencionalmente associados para os componentes pistões/camisa/anéis apoiam-se em diferentes modos de lubrificação para um desempenho satisfatório e de fato cada um deles 
pode enfrentar mais do que uma forma de lubrificação durante o ciclo de funcionamento do motor.

A formulação do óleo lubrificante afeta fortemente o contato limite entre as superfícies dos anéis e cilindros. Aditivos antidesgaste, como aqueles à base de molibdênio, utilizados em lubrificantes, contribuem positivamente para a formação de uma camada resistente ao desgaste entre os componentes. A quantidade de lubrificante disponível entre as superfícies em contato determina o mecanismo de atrito nas condições de funcionamento de ponto motor superior e inferior do movimento dos anéis. Os efeitos da lubrificação hidrodinâmica são os responsáveis pela determinação do mecanismo de atrito durante o deslocamento do pistão na região central do cilindro (TRUHAN et al., 2005). Além da lubrificação, a carga, velocidade, viscosidade e geometria de contato são determinantes no contato deslizante do anel.

TABELA 5 - Resumo dos regimes de lubrificação

Regime de

lubrificação

Características

Filme lubrificante completo com separação das superfícies. A

Hidrodinâmica viscosidade dinâmica do fluido é a propriedade mais importante.

Normalmente também o filme lubrificante é completo com separação das superfícies, mas um mecanismo mais

hidrodinâmica concentrado onde deformação elástica das superfícies e o efeito da pressão sobre a viscosidade é mais importante.

Existe certo grau de interação entre as asperezas das

Mista superfícies e a característica de ambos os regimes de lubrificação hidrodinâmico e elasto-hidrodinâmico.

Limite $\quad$ As superfícies estão em contato normal sendo caracterizado pela ação química e física de filmes moleculares.

Fonte - TAYLOR, 1998; PRIEST, 2000.

\subsubsection{Influência do brunimento na redução do atrito do motor}

Análises feitas por TOMANIK (2008) sobre o COF de diferentes superfícies rugosas de camisas contra segmentos de anéis de pistão por intermédio de testes recíprocos de contato em bancada, concluíram que quando o 
regime de lubrificação se aproxima da condição limite/mista, ou seja, quando a relação velocidade recíproca dividida pelo carregamento normal tende a zero, os resultados de COF medidos tendem para um valor ao redor de 0,11. Este resultado mostra que nesta condição de lubrificação o comportamento do COF é sobre mais influencia das propriedades do material e não pelo óleo lubrificante. No entanto, ao se aumentar a velocidade recíproca e conservando o carregamento normal sobre o segmento de anel de pistão, observa-se a redução dos respectivos valores de COF, sendo um comportamento diferente para cada condição de rugosidade analisada. Para esta segunda situação verifica-se a influencia da rugosidade mais fina na redução mais brusca do COF, reforçando a teoria de Stribek como mostrado na FIG. 24, ou seja, ocorreu uma mudança do regime de lubrificação, saindo da condição limite/mista para a condição elastrohidrodinâmica. A FIG. 25 ilustra a rugosidade das superfícies brunidas antes dos testes, pelo método de medição 2D "Stylus" e na FIG. 26 os respectivos parâmetros de rugosidade da série Rk são compilados em gráfico de barras.

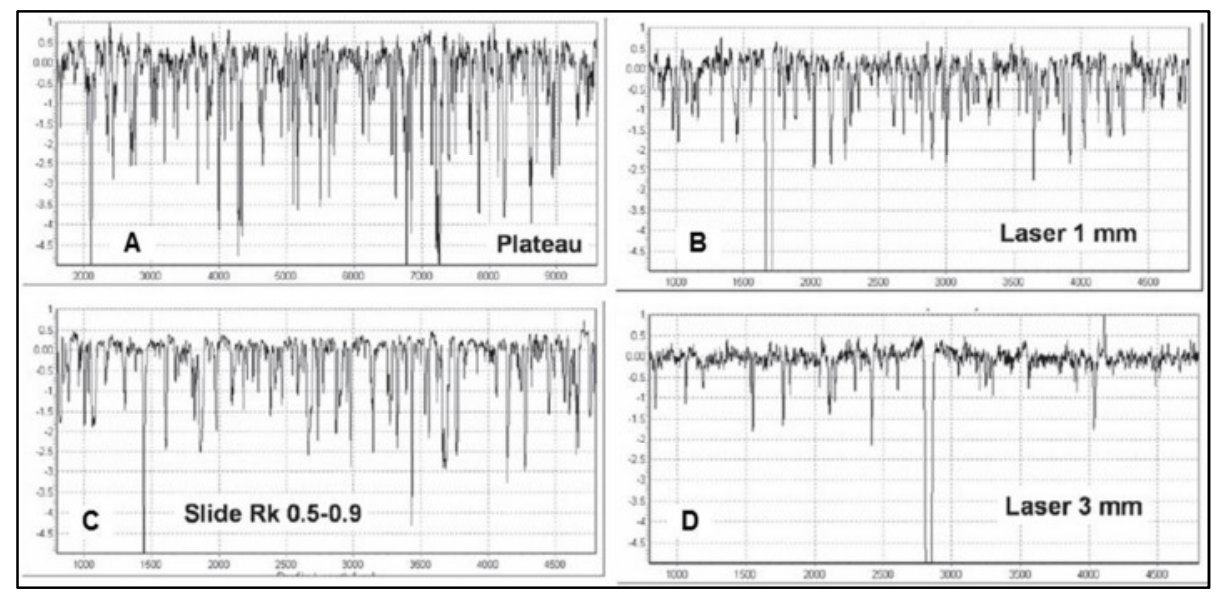

FIGURA 25 - Medição da rugosidade de diversos brunimentos. (A) "Plateau honing" (Rk 0,5-1,2 $\mu \mathrm{m})$; (B) "Laser honing" com bolsões de óleo (1 mm); (C) "Slide honing" (Rk 0,5-0,9 $\mu \mathrm{m}$ ); (D) "Laser honing" com bolsões de óleo (3 $\mathrm{mm}$ ) (TOMANIK, 2008). 


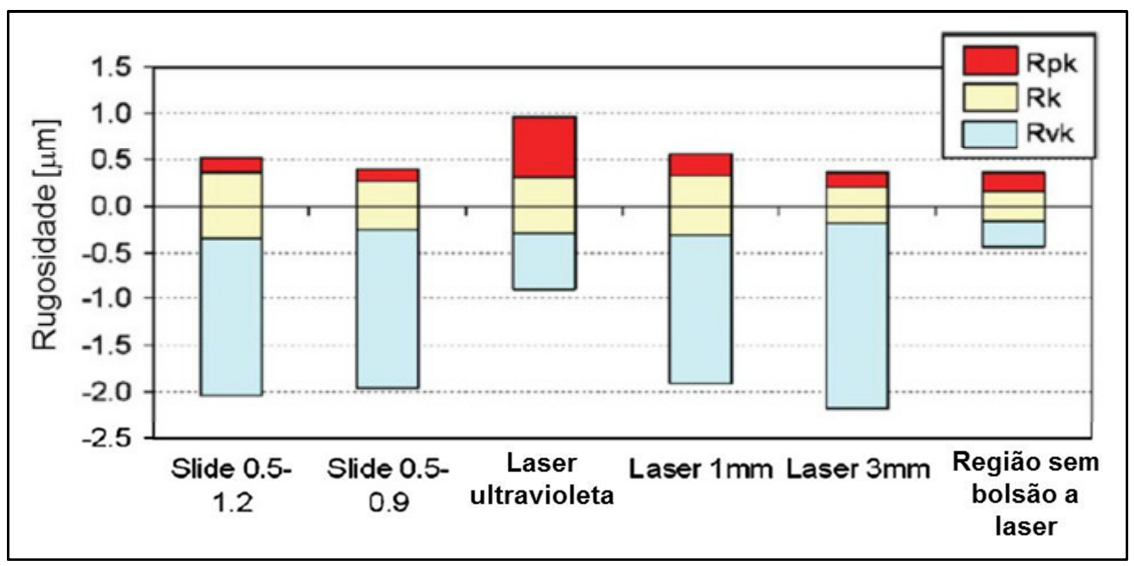

FIGURA 26 - Parâmetros da série Rk para diferentes superfícies usinadas (TOMANIK, 2008).

A FIG. 27 apresenta a redução dos valores de COF em função da velocidade recíproca e carregamento normal constante de $50 \mathrm{~N}$.

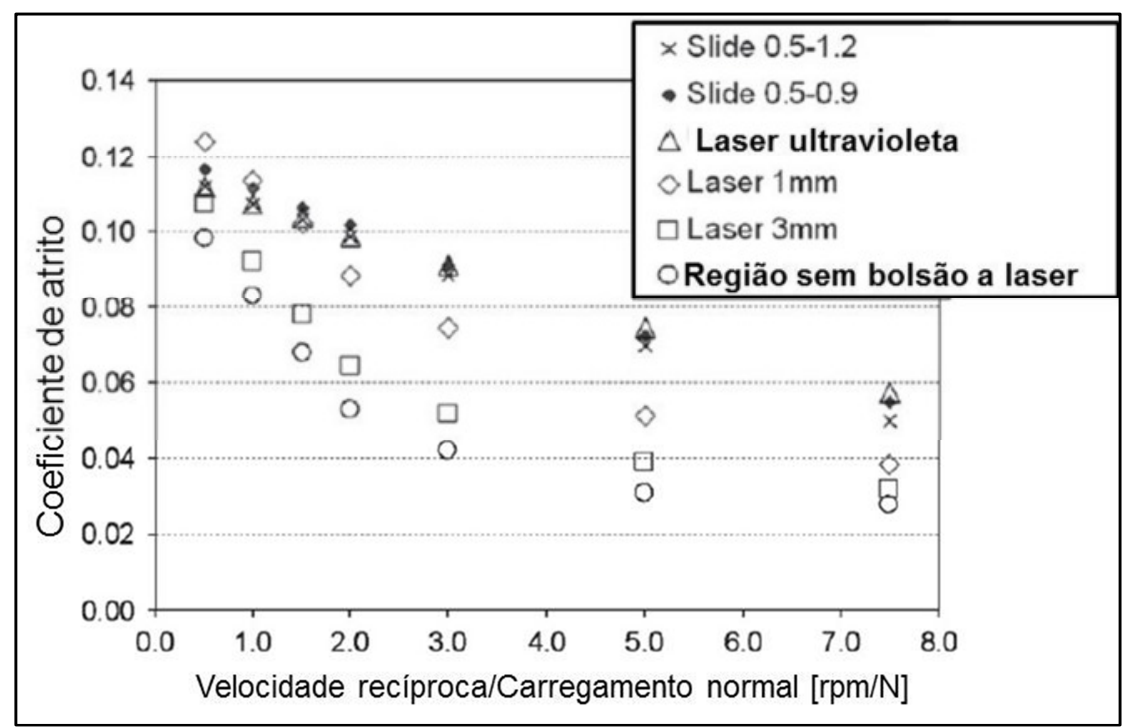

FIGURA 27 - COF para diferentes superfícies (TOMANIK, 2008).

\subsection{Mecanismos de desgaste em camisas de cilindro}

Segundo GAHR (1987), o desgaste pode ocorrer com perda de material ou com danos à superfície dos corpos em contato. A norma DIN 50320 (1979) classifica os seguintes mecanismos de desgaste:

- desgaste adesivo (formação e quebra das ligações interfaciais adesivas);

- desgaste abrasivo (remoção do material devido ranhura); 
- desgaste corrosivo (interação química entre os elementos, que resulta em reação química);

- fadiga de superfície (fadiga e formação de trincas devido a ciclos de tensões).

Conforme sugerido por PAWLUS e MICHALSKI (2009) a superfície acabada da camisa é um dos fatores mais importantes que afetam o atrito, o desgaste e o regime de lubrificação entre os componentes do sistema pistão dentro do motor. A alteração da topografia original gerada pelo processo de brunimento pode causar um polimento na superfície, conhecida como "bore polishing" que é um indicador iminente de falha por engripamento dos anéis de pistão. O nível de rugosidade da superfície brunida pode afetar o tempo de amaciamento, o consumo de óleo, as emissões de gases de exaustão e o desempenho do motor. Segundo JOHNSON e SHERCLIFF (1991), o ciclo de amaciamento entre a superfície brunida da camisa de cilindro e as faces de contato dos anéis de pistão proporciona uma mudança nos perfis rugosos devido aos movimentos de vai-e-vem repetitivo dos anéis sobre a superfície brunida. Dois mecanismos de desgaste ocorrem, a movimentação plástica sem a perda de material que caracteriza um rearranjo da rugosidade e outra com perda de material por desgaste adesivo ou abrasivo.

\subsubsection{Desgaste adesivo}

O desgaste adesivo pode ocorrer quando as superfícies deslizam uma contra a outra. A alta pressão local entre as asperezas em contato resulta em deformação plástica, adesão e consequentemente a formação de junções localizadas. O deslizamento relativo entre as superfícies em contato causa ruptura destas junções e frequentemente transfere material de uma superfície para outra, o que pode aumentar o risco de sobrecarga devido à tensão, velocidade ou temperatura, sendo relacionado a um grande aumento do coeficiente de atrito e desgaste. A formação de junção no local do contato entre as duas superfícies pode ser formada por adesão ou coesão. Coesão une as superfícies através de uma solda e do desaparecimento da interface entre as duas superfícies. Adesão preserva a interface na junção. A FIG. 28 mostra diferentes maneiras de como as 
micro-soldas podem se localizar na interface. Após o destacamento, o mecanismo de desgaste pode tornar-se do tipo abrasivo a três corpos (GAHR, 1987).

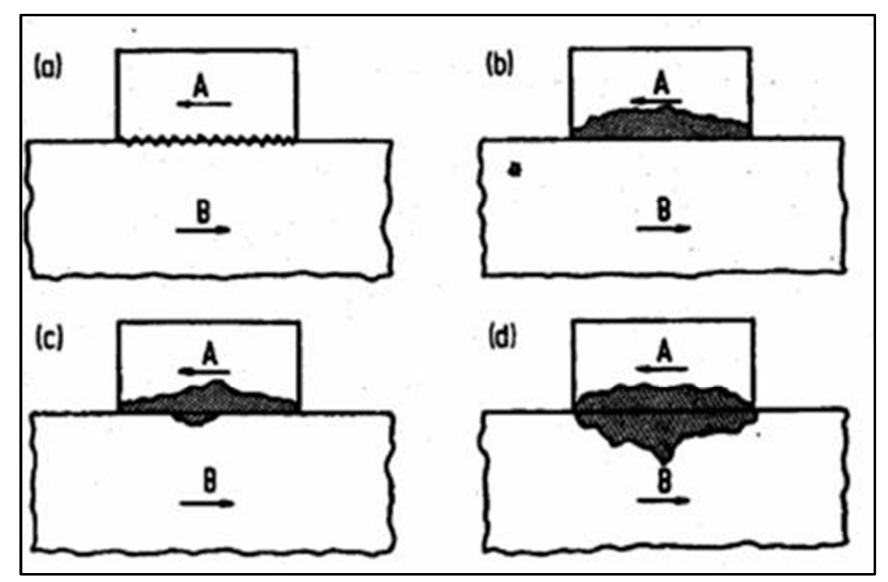

FIGURA 28 - Formações de junções por adesão, onde (a) não há perda de material; (b) haverá subtração de material somente do corpo; (c) e (d) haverá desprendimento em ambos os corpos, segundo a área escura pintada (GAHR, 1987).

A tendência para formar juntas aderidas depende das propriedades físicas e químicas dos materiais em contato, do modo e valor da carga, bem como de contaminantes e rugosidades. Frequentemente, os contatos entre metais são de fato não-metálicos, uma vez que as superfícies são cobertas por camadas adsorvidas, ou filmes de óxidos. A adesão de um metal em um não-metal é primeiramente causada por forças fracas de "Wan der Waals". Camadas adsorvidas e filmes de óxidos podem se quebrar devido a deformações elásticas e plásticas das asperezas. Neste caso, a adesão é causada por ligações covalentes ou metálicas, uma vez que ligações iônicas são desprezíveis para os metais (GAHR, 1987).

\subsubsection{Desgaste abrasivo}

Desgaste abrasivo é a retirada de material causada pela presença de partículas de elevada dureza, que podem estar aprisionadas na interface entre as duas superfícies em movimento relativo, ou causada pelas protuberâncias relativas à rugosidade de uma das superfícies. 
Uma partícula dura pode ser produto de um processo, como sílica, um fragmento desgastado, ou advindo de eventuais partículas de fora do sistema tribológico, como sujeiras.

Desgaste abrasivo pode ocorrer em baixo ou alto nível dependendo da razão entre a dureza da partícula e da superfície. O desgaste abrasivo está relacionado a alguns mecanismos, dentre eles os principais estão apresentados na FIG. 29, sendo denominados como: micro-sulcamento, micro-corte, microfadiga e micro-trinca (GAHR,1987).

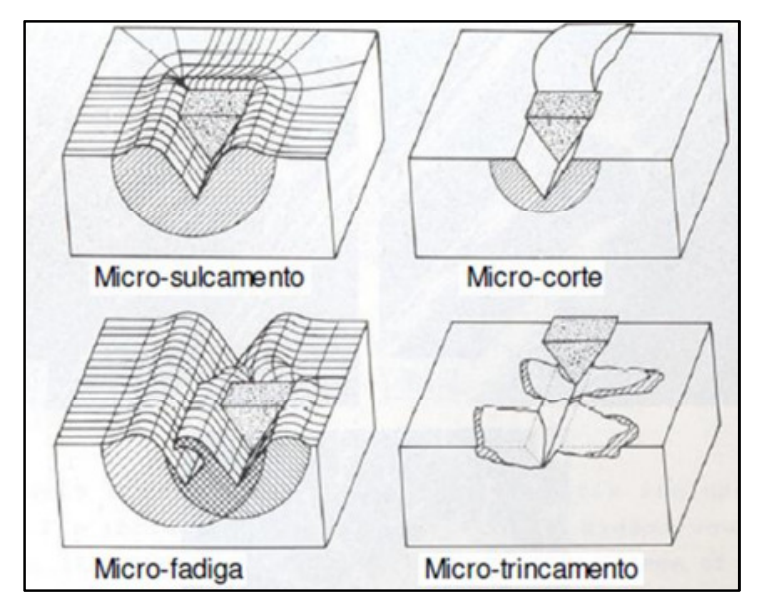

FIGURA 29 - Mecanismos de desgaste envolvidos em desgaste abrasivo (GAHR, 1987).

O desgaste abrasivo pode ser classificado como de dois ou três corpos. O desgaste abrasivo de dois corpos ocorre uma das superfícies tem partículas duras protuberantes. Essas partículas abrasivas agem como elementos de interface entre o corpo sólido e o contra. No desgaste abrasivo de três corpos as partículas duras são livres para rolar e deslizar entre as duas superfícies. $O$ desgaste quando envolve três corpos é cerca de duas a três vezes menor do que quando envolve dois corpos. Pois, no caso de três corpos, devido à variação no ângulo de ataque, apenas uma pequena porção das partículas causa desgaste. Eventualmente um processo abrasivo de três corpos pode se tornar num processo de dois corpos, se a partícula dura penetrar e ficar impregnada numa das superfícies, geralmente mais mole. Neste caso, a maior taxa de desgaste ocorre na superfície mais dura e não na mais mole (TOMANIK, 2000). 
Micro-sulcamento e micro-corte são mecanismos dominantes em materiais mais dúcteis. A ocorrência de um deles vai depender do ângulo de ataque das partículas abrasivas. O micro-corte ocorre a partir de um ângulo de ataque crítico. Este ângulo de ataque crítico é função do material que está sendo desgastado e das condições de teste. A transição do mecanismo de microsulcamento para micro-corte depende também do coeficiente de atrito. Normalmente, o mecanismo passa de micro-sulcamento para micro-corte com o aumento da dureza do material que está sendo desgastado. Aumentos ainda maiores de dureza resultam na passagem de micro-corte para micro-trinca.

A micro-trinca pode ocorrer quando são impostas elevadas tensões sobre as partículas abrasivas, particularmente em superfícies de materiais frágeis. Neste caso, grande quantidade de particuladas é retirada da superfície devido à formação e propagação de trinca. Partículas de menor ou igual dureza que a superfície também podem desgastá-la. O ataque das partículas macias pode resultar em deformação elástica e plástica, fadiga de superfície, resultando num severo desgaste. (GAHR,1987).

\subsection{Medição do desgaste em camisas após teste de rodagem}

Um desgaste anormal na camisa de cilindro afeta o consumo de óleo, reduz a vida do motor e pode causar engripamento (TOMANIK, 1992). O método convencional de se medir o desgaste num cilindro é medir o perfil da superfície de trabalho da camisa de cilindro no sentido longitudinal e radial. Três tipos de desgaste podem ser definidos:

- Desgaste abrasivo ou adesivo causado pelo pistão, que pode ser observado no sentido longitudinal da superfície de trabalho da camisa de cilindro, localizado nas regiões de pressão e contra pressão;

- desgaste abrasivo ou adesivo causado pelos anéis de pistão, que geralmente são localizados nas regiões de reversão dos anéis;

- desgaste acelerado por corrosão, devido à alta quantidade de enxofre contida no combustível, o que gera superfícies de contato com padrão diferenciado.

A aplicação de um revestimento na camisa já fundida melhora a resistência ao desgaste da superfície de trabalho. Para isso, utilizam-se 
tradicionalmente processos como a cromação e revestimentos superficiais à base de níquel. Novos processos como a deposição de filme por transferência térmica de material por plasma estão sendo utilizados em cilindros para motores com até 140 mm de diâmetro, PISCHINGER (2007).

\subsection{Engenharia de superfície em componentes de motor}

Segundo BEWILOGUA et al. (2009), em geral as superfícies não são perfeitas. Entretanto, no dia a dia a nossa interação com os objetos se dá pelo contato com as respectivas superfícies. A engenharia de superfície busca a melhoria de materiais e produtos existentes, o que a torna indispensável principalmente para produtos de inovação que se baseiam nas propriedades particulares de filmes finos. Ainda segundo BEWILOGUA et al. (2009), tecnologia de superfície significa modificação, reestruturação ou revestimento de materiais em componentes. No caso de revestimentos, existe uma diferenciação entre as tecnologias de revestimento de filmes espesso e fino. A tecnologia de filmes espessos compreende espessuras acima de $10 \mu \mathrm{m}$ enquanto que as de filme fino espessuras entre 0,1 nm e $10 \mu \mathrm{m}$. Contudo na prática, esta divisão não é fixa.

De acordo com BUNSHAH (1994), a partir da década de 50, os revestimentos decorativos e o uso do alumínio apareceram como as principais soluções para a engenharia de superfície, inicialmente aplicadas em brinquedos e calandras para fabricação de tecidos. Deste então, se iniciou a aplicação das técnicas de revestimento em praticamente todas as áreas da engenharia e, consequentemente, muitas áreas vivenciaram um crescimento em vendas de equipamentos e na produção de produtos revestidos. A engenharia de superfície influenciou no crescimento da indústria porque introduziu componentes de melhor desempenho, menor custo, melhores propriedades de superfície, independente do substrato, conferindo um enorme potencial de aplicação.

Conforme MATTOX (1998), a engenharia de superfície envolve mudança de propriedades da superfície e da região próxima da superfície de trabalho para uma solução desejada. A engenharia de superfície pode envolver um processo de recobrimento ou um processo de modificação da superfície. No processo de recobrimento, um material é adicionado sobre a superfície recobrindo o substrato do componente de forma homogênea. O processo de modificação da 
superfície modifica as propriedades da superfície de contato, mantendo as características do substrato. Cada processo possui as suas vantagens, desvantagens e respectivas aplicações.

A indústria automotiva é atualmente considerada a mais importante usuária dos benefícios que a engenharia de superfície pode proporcionar (BEWILOGUA et al., 2009).

Atualmente, uma série de componentes de motor e de transmissão em automóveis são revestidos para reduzir o desgaste e o atrito dos materiais, aumentando assim a vida útil do componente, reduzindo o consumo de combustível e atuando na prevenção contra ao desgaste por corrosão. Existe uma enorme variedade de processos básicos e outros derivados com maior complexidade para deposição de revestimentos ou modificação de superfícies, como por exemplo, a têmpera por indução em superfícies metálicas (MATTOX, 1998).

\subsection{Filmes à base de carbono tipo diamante - DLC}

O carbono pode ser encontrado na natureza em diferentes formas alotrópicas, tais como: o grafite, o diamante, os fulerenos e os nano-tubos. Pode ser encontrado também em formas amorfas como: o carvão, o carbono vítreo, fibras de carbono e o carbono amorfo.

O filme de carbono tipo diamante (DLC) é uma forma metaestável de carbono e pode apresentar hibridizações $\mathrm{sp}^{3}, \mathrm{sp}^{2}$ e $\mathrm{sp}^{1}$ (ROBERTSON, 2002), como apresentado na FIG. 30. Na configuração $\mathrm{sp}^{3}$, o carbono forma quatro orbitais $\mathrm{sp}^{3}$, para fazer fortes ligações $\sigma$ com os átomos adjacentes. $\mathrm{Na}$ configuração $\mathrm{sp}^{2}$, são formadas três orbitais $\mathrm{sp}^{2}$ para realizar as ligações $\sigma$, e o quarto orbital forma uma ligação $\pi$ como o átomo vizinho. Para a hibridação tipo $\mathrm{sp}^{1}$, há duas ligações $\sigma$ ao longo do eixo x e duas ligações $\pi$. 


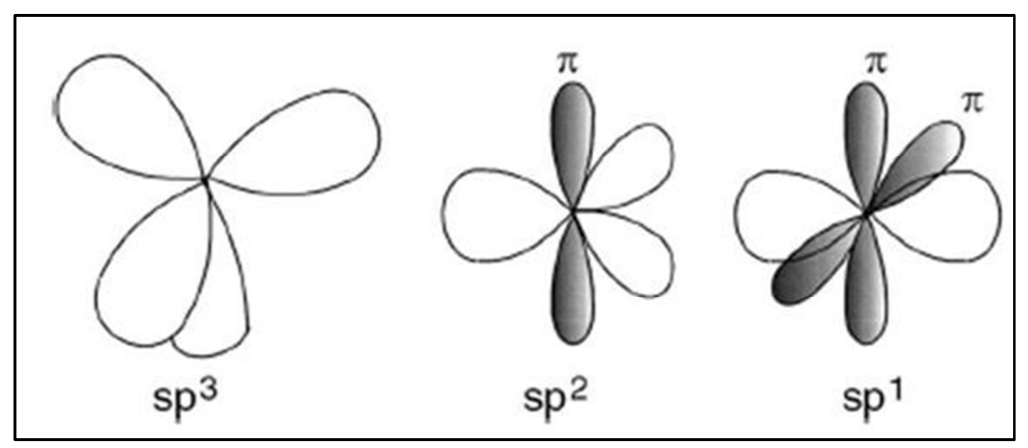

FIGURA 30 - Hibridizações do carbono (ROBERTSON, 2002).

Segundo GRILL (1999a; 1999b), o DLC é um nome atribuído a uma variedade de materiais à base de carbono amorfo, alguns contém até $50 \%$ em peso de hidrogênio (a-C:H) e outros contêm menos de $1 \%$ em peso (a-C). Os filmes de carbono tipo diamante contém significativas frações $\mathrm{sp}^{3}$ do tipo $\mathrm{C}$, o que confere a esses filmes propriedades físicas e mecânicas que são, até certo ponto, semelhantes às do diamante. Os filmes a-C:H tipicamente contêm frações $\mathrm{sp}^{3}$ inferiores a $50 \%$, enquanto que os filmes a-C podem conter $85 \%$ ou mais de ligações $\mathrm{sp}^{3}$.

Os filmes de carbono amorfo (a-C) e de carbono amorfo hidrogenado $(\mathrm{a}-\mathrm{C}: \mathrm{H})$ têm uma mistura de hibridizações dos tipos $\mathrm{sp}^{2}$ e $\mathrm{sp}^{3}$ e até mesmo $\mathrm{sp}^{1}$. Possuem algumas propriedades similares às do diamante, tais como, alta dureza e módulo elástico e são quimicamente inertes.

A distribuição das várias formas de misturas amorfas do carbono no chamado diagrama de fase ternário $\mathrm{C}-\mathrm{H}$ pode ser observado na FIG. 31. Neste gráfico pode-se observar que na parte inferior esquerda se encontram filmes a-C que apresentam estruturas de grafite desordenadas. $O$ vértice direito do triângulo contém dois polímeros: polietileno $\left(\mathrm{CH}_{2}\right)$ n e poliacetileno $(\mathrm{CH}) \mathrm{n}$, além de ligações C-C que não formam filmes, só moléculas. No vértice superior do triângulo está o diamante. Diversos métodos de deposição de DLC foram desenvolvidos para obter filmes com maior conteúdo de hibridações $\mathrm{sp}^{3}$. Os filmes foram denominados de filmes de carbono amorfo com alta porcentagem de hibridação $\mathrm{sp}^{3}$ de carbono amorfo tetraédrico (ta-C), para diferenciá-los dos a-C com maior quantidade de átomos de carbono com hibridização $\mathrm{sp}^{2}$. Utilizando o método de deposição PACVD podem ser obtidos materiais no centro do triângulo, neste caso 
o a-C:H e ta-C:H (GRILL, 1999a; 1999b; ROBERTSON, 2002). A técnica PACVD foi utilizada neste trabalho e será abordada mais adiante.

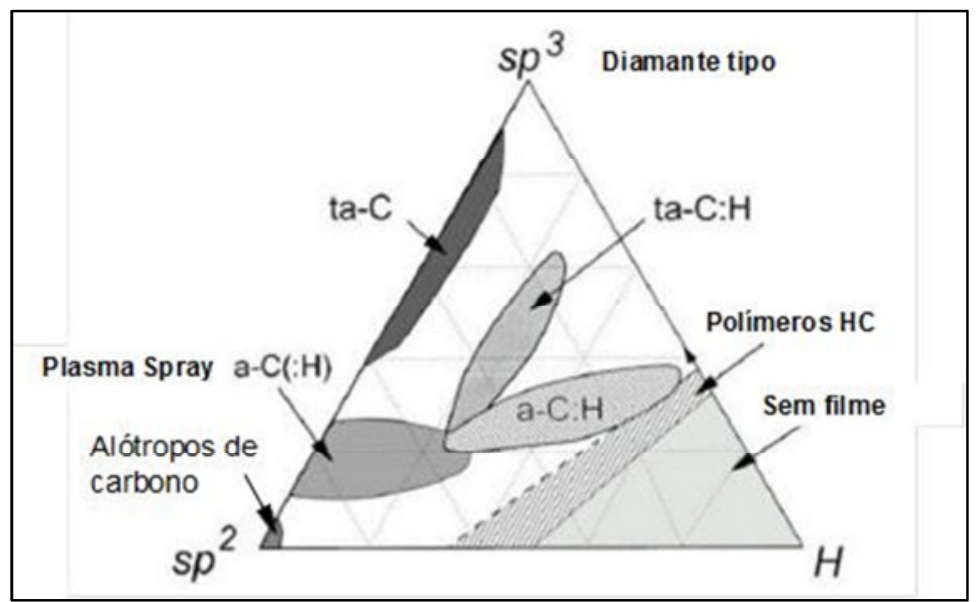

FIGURA 31 - Diagrama de fase ternário mostrando a estrutura de carbono amorfo hidrogenado (GRILL, 1999a).

Tanto o diamante quanto os filmes DLC crescem a partir de hidrocarbonos contidos em gases. A deposição do diamante normalmente requer temperatura elevada do substrato, enquanto que a deposição do DLC pode ser feita com a temperatura do substrato abaixo de $325^{\circ} \mathrm{C}$. Entretanto, a temperatura não é o principal fator diferencial na síntese desses dois materiais. A elevada temperatura do substrato por si só não é suficiente para obter filmes de diamante por deposição de vapor químico ou "chemical vapor deposition" (CVD). A técnica CVD a partir de hidrocarbonos em substratos com temperatura elevada resulta na formação de um carbono grafítico termodinamicamente estável. Para haver crescimento de um filme de diamante, o substrato e a superfície devem ser expostos a um meio contendo elevada concentração de átomos de hidrogênio e/ou oxigênio, cujo propósito é prevenir a formação de fases de não-diamante. $O$ DLC tem que crescer em baixas temperaturas para prevenir a grafitização, e sob condições de bombardeamento de íons. Inclusive, a incorporação de hidrogênio nos filmes DLC é importante para se obter propriedades semelhantes às do diamante (GRILL 1999b).

Segundo BEWILOGUA et al. (2009), os filmes de carbono tipo diamante são bem conhecidos pela sua alta dureza e resistência ao desgaste, assim como por baixos coeficientes de atrito e, em alguns casos pela baixa 
tensão de superfície. Comumente, existe uma distinção entre os filmes sem dopagem de hidrogênio (a-C ou ta-C) e os com dopagem de hidrogênio (a-C:H). Ambos os tipos podem ser modificados pela adição de elementos metálicos (a$\mathrm{C}: \mathrm{H}: \mathrm{Me}$ ) e não metálicos (a-C:H:X-X: elementos adicionais). Especialmente filmes com dopagem por hidrogênio a-C:H e com a adição de metais a:C-H:Me são hoje aplicados com sucesso na indústria, principalmente para componentes automotivos.

Propriedades interessantes e promissoras podem ser alcançadas dopando o filme DLC com elementos não metálicos ( $\mathrm{Si}, \mathrm{O}, \mathrm{F}, \mathrm{N}$ ). O filme DLC do tipo a-C:H:Si é conhecido por apresentar COF menores do que os filmes do tipo a-C:H. Filmes que contenham Si e O (a-C:H:Si:O) são caracterizados pela baixa energia de superfície comparados com o material TEFLON ${ }^{\circledR}$. A baixa energia superficial leva à diminuição da propriedade de aderência de um lubrificante, conhecida como molhabilidade, afetando de certa forma a resistência ao desgaste do filme. A TAB. 6 ilustra algumas propriedades de diferentes filmes DLC amorfos como: a dureza, o desgaste abrasivo, o ângulo de contato formado por uma gota de água que relaciona a propriedade de molhabilidade superficial do filme, e a energia superficial (BEWILOGUA et al., 2009).

TABELA 6 - Propriedades relacionadas ao desgaste do filme DLC.

\begin{tabular}{cccccc}
\hline & $\begin{array}{c}\text { Dureza } \\
{[\mathrm{GPa}]}\end{array}$ & $\begin{array}{c}\text { COF (Esfera de } \\
\text { aço sobre disco } \\
\text { - Ambiente) }\end{array}$ & $\begin{array}{c}\text { Desgaste } \\
\text { abrasivo [x10 } \\
\left.15 \mathrm{~m}^{3} / \mathrm{Nm}\right]\end{array}$ & $\begin{array}{c}\text { Angulo da } \\
\text { gota de } \\
\left.\text { água [ }{ }^{\circ}\right]\end{array}$ & $\begin{array}{c}\text { Energia } \\
\text { superficial } \\
{[\mathrm{mN} / \mathrm{m}]}\end{array}$ \\
\hline a-C:H & $25-35$ & $0,15-0,20$ & $0,5-1$ & $70-75$ & 40 \\
a-C:H:Si & 20 & $<0,10$ & $2-4$ & $75-80$ & 38 \\
a-C:H:Si & $8-10$ & $0,40-0,60$ & $10-15$ & $95-105$ & 24 \\
a-C:H:W & $15-20$ & 0,20 & $1-4$ & $65-70$ & 42 \\
\hline
\end{tabular}

Fonte - BEWILOGUA et al., 2009.

Segundo a norma VDI 2840 (2005), que sugere uma referência para filmes à base de carbono tipo diamante depositados por métodos de deposição a vácuo como o (PVD) "Physical Vapor Deposition" e CVD, define uma designação técnica para cada tipo de filme DLC, incluindo os casos com estrutura cristalina e 
amorfa assim como os respectivos processos de deposição recomendados. A FIG. 32 apresenta um fluxograma dos filmes DLC com as designações recomendadas e os processos de deposição.

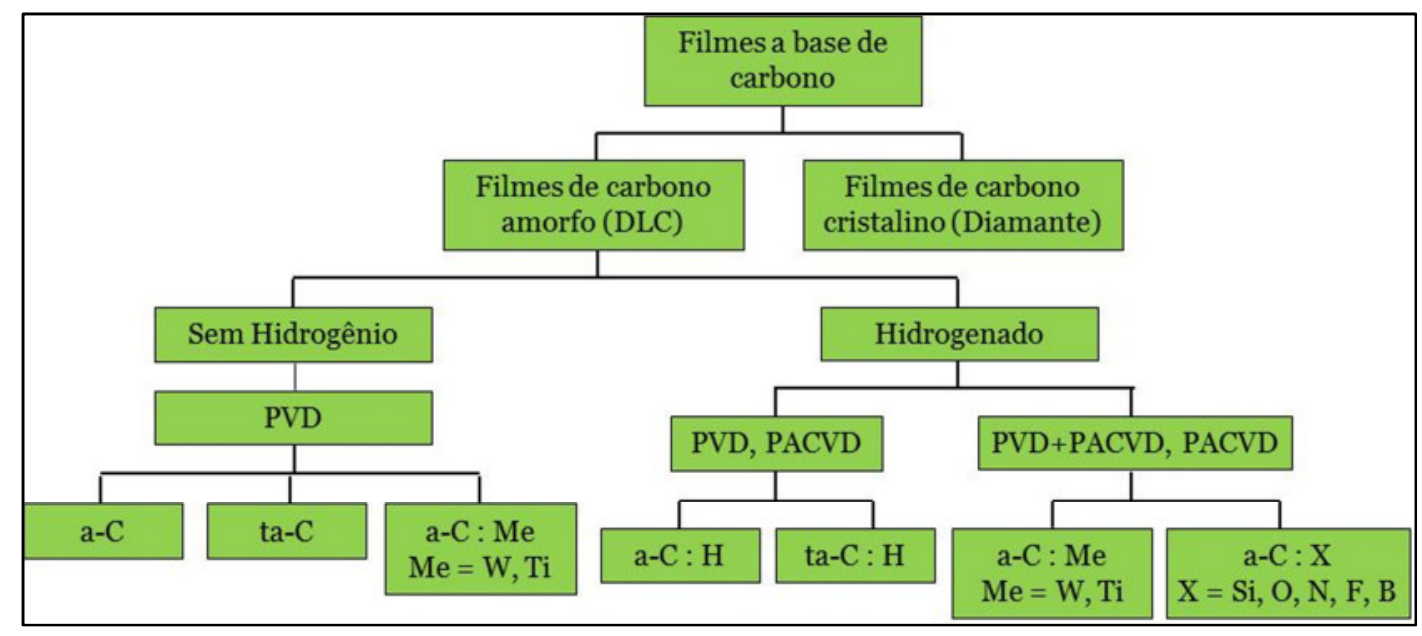

FIGURA 32 - Filmes DLC e suas designações (VDI 2840, 2005).

\subsubsection{Incorporação de átomos de Si em filmes de carbono amorfo}

A incorporação de silício nos filmes DLC tem despertado bastante interesse dos pesquisadores já que demonstra grande potencial para resolver alguns dos maiores problemas dos filmes puros de DLC, como a elevada tensão interna residual de natureza compressiva (DAMASCENO et al., 2000; DAMASCENO et al., 2002).

De fato, os filmes DLC dopados com Si apresentam baixa tensão residual interna, elevada taxa de deposição, boa adesão para a maioria dos substratos incluindo ligas metálicas, como os aços, e sobre vidros, elevada dureza, melhor estabilidade térmica, reduzida perda de hidrogênio e grafitização, baixo coeficiente de atrito independente da umidade relativa, resistência à oxidação e à corrosão. Essa gama de propriedades faz com que esse material seja um candidato promissor para um elevado número de aplicações tecnológicas como recobrimentos metalúrgicos de baixo atrito e elevada resistência ao desgaste assim como filmes protetores.

A adição de silano na mistura gasosa contribui para o aumento da taxa de deposição dos filmes a-C:H:Si. Este comportamento é devido ao fato da energia de dissociação do $\mathrm{CH}_{4}$ ser maior do que a do $\mathrm{SiH}_{4}$. Para baixos valores 
de tensão e corrente a maioria das moléculas de $\mathrm{SiH}_{4}$ se decompõe, enquanto que, somente uma pequena fração do $\mathrm{CH}_{4}$ é dissociada. Com o aumento dessas características de processo a fração de $\mathrm{SiH}_{4}$ dissociada não deve aumentar muito, ao passo que a fração de $\mathrm{CH}_{4}$ dissociada aumenta. A FIG. 33 mostra os resultados obtidos para a taxa de deposição como função da polarização ou "selfbias" para duas diferentes concentrações de silano na mistura gasosa, 0,2 e 2,0 vol \% (DAMASCENO et al., 2000).

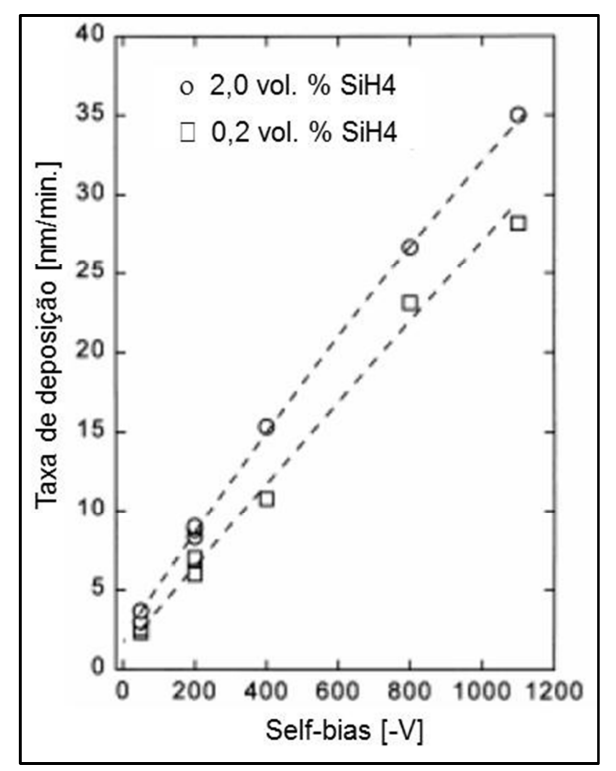

FIGURA 33 - Taxa de deposição como função da polarização para duas concentrações diferentes de $\mathrm{SiH}_{4}$ na mistura gasosa, 0,2 e 2,0 vol \% (DAMASCENO et al., 2000).

Os filmes DLC hidrogenados dopados com silício (a-C:H:Si) exibem baixa tensão residual, enquanto que mantêm aproximadamente constante a dureza. Uma possível explicação para essa redução na tensão interna compressiva é a mudança nas propriedades microestruturais do filme (DAMASCENO et al., 2002).

De fato, BAIA NETO et al. (1997) afirmam que a incorporação de átomos de silício induz a redução da razão $\mathrm{sp}^{2} / \mathrm{sp}^{3}$ de ligações de carbono, há redução na densidade e no tamanho dos defeitos grafíticos. Sugerem que o material apresenta um aumento na quantidade de vazios, e com isso há diminuição na sua densidade. Isso porque sendo os átomos de silício maiores do 
que os de carbono, quando há substituição de carbono pelo silício nas ligações há também uma mudança na estrutura, havendo formação de mais vazios.

BAIA NETO et al. (1997) demonstraram que apesar de ter havido aumento da fração $\mathrm{sp}^{3}$ nos filmes DLC-Si não houve aumento da dureza, provavelmente pelo fato de se ter obtido um material menos compacto e/ou porque as ligações carbono-carbono foram substituídas por ligações mais fracas de silício-carbono na formação da estrutura amorfa. A FIG. 34 mostra gráficos que relacionam tensão interna e dureza, e concentração de silano $\left(\mathrm{SiH}_{4}\right)$.

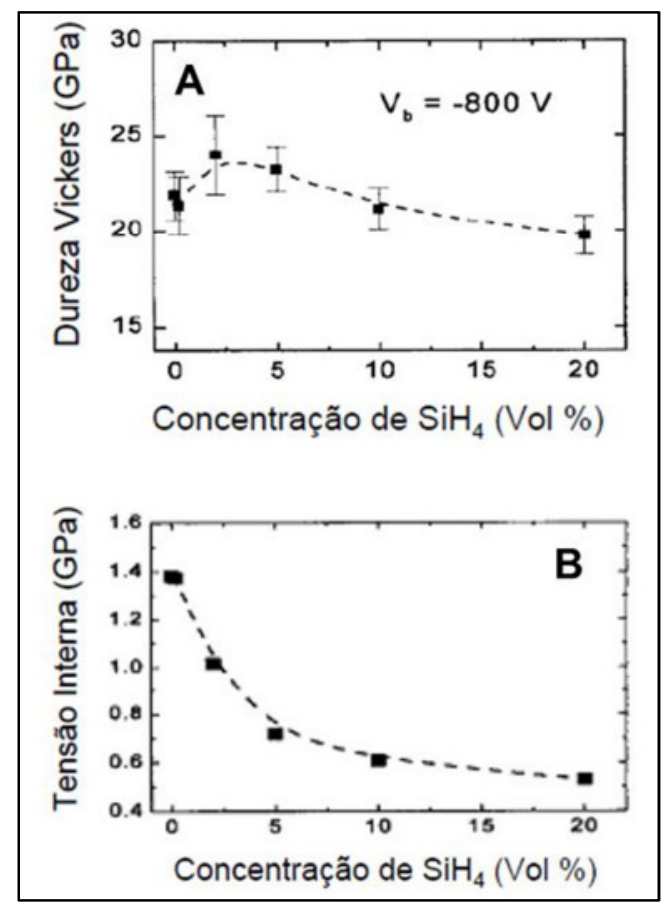

FIGURA 34 - (A) Dureza vs. concentração de $\mathrm{SiH}_{4}$, (B) Tensão interna vs. concentração de $\mathrm{SiH}_{4}$ (DAMASCENO et al., 2000).

DAMASCENO et al. (2000) mostraram ser possível a obtenção de filmes DLC-Si com elevada dureza (maior do que $20 \mathrm{GPa}$ ), baixa tensão (0,5 $\mathrm{GPa}$ ) e elevada taxa de deposição (maior do que $40 \mathrm{~nm} /$ minuto) pela técnica PACVD, com uma mistura de gás metano $\left(\mathrm{CH}_{4}\right)$ e silano $\left(\mathrm{SiH}_{4}\right)$.

Resultados semelhantes para o efeito da incorporação de Si (10 at.\%) sobre a tensão interna e dureza dos filmes DLC, também, foram obtidos por GANGOPADHYAY et al. (1997), como pode ser observado na FIG. 35. 


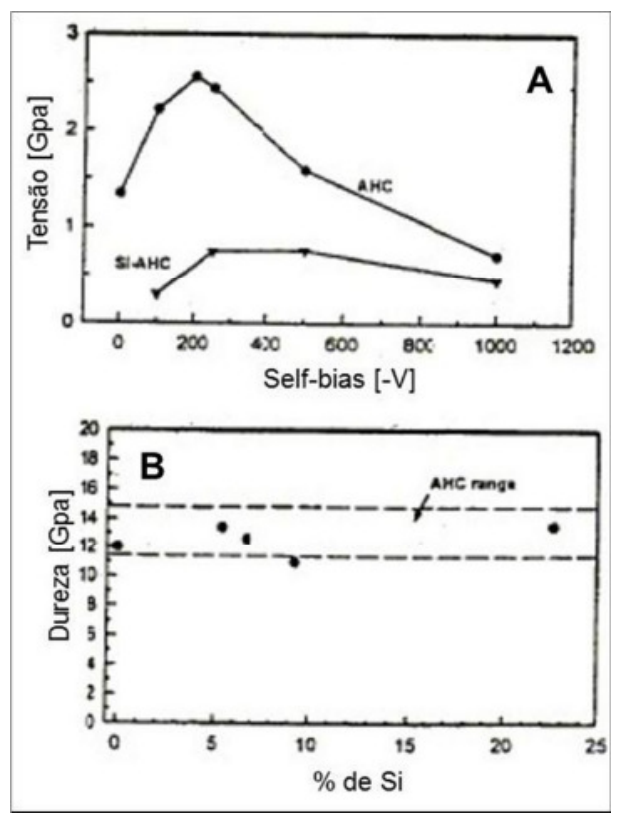

FIGURA 35 - (A) Efeito da incorporação de Si (10 at.\%) em filmes DLC em função da polarização e (B) comparação da dureza de filmes DLC com filmes Si-DLC em relação à concentração de Si (GANGOPADHYAY et al., 1997).

Outro efeito importante na incorporação de Si em filmes de DLC é a inibição dos processos de grafitização e perda de hidrogênio com a temperatura, fazendo com que os filmes de DLC com adição de silício tenham maior estabilidade térmica (GANGOPADHYAY et al., 1997; BAIA NETO et al., 1997).

\subsubsection{Propriedades mecânicas nos filmes DLC}

Segundo GRILL (1999a) e LIFSHITZ (1999) os filmes de a-C:H são caracterizados por apresentarem elevada dureza (10-30 GPa) com módulo de elasticidade de 6 a 10 vezes maior, porém elevada tensão interna compressiva $(0,5$ a $7 \mathrm{GPa})$. As propriedades estão diretamente correlacionadas à fração $\mathrm{sp}^{3}$ do carbono nos filmes.

A dureza nos filmes não hidrogenados (ta-C ou a-C) pode atingir valores ainda mais elevados, na ordem de 40-80 GPa e seu módulo de elasticidade pode alcançar valores superiores a 900 GPa. A tensão interna também tem seu valor aumentado podendo chegar a $13 \mathrm{GPa}$, o que limita a espessura máxima do filme, que deve ser inferior a $1 \mu \mathrm{m}$.

O controle de tais tensões é de grande importância já que filmes muito tensionados caracterizam-se por baixa adesão, podendo assim ocorrer 
delaminação. Como tais filmes são quimicamente inertes, a adesão a determinados substratos não se mostra satisfatória fazendo com que uma camada intermediária (entre o substrato e o filme) seja sendo utilizada para melhorar a adesão (GRILL, 1999b; FONTAINE et al., 2001).

LIFSHITZ (1999) e FONTAINE et al. (2001) afirmam que tal tensão residual também pode ser reduzida pela incorporação de átomos de $\mathrm{N}, \mathrm{Si}, \mathrm{O}$ ou outros metais ao filme.

Dentre as várias propriedades dos filmes DLC, GRILL (1999a; 1999b) e ROBERTSON (2003) citam elevada dureza, elevado módulo de elasticidade, baixa rugosidade, inerte a reações químicas, tanto em meio alcalino quanto ácido, elevada resistividade elétrica, instabilidade térmica (acima de $325^{\circ} \mathrm{C}$ ) e comportamento semi-condutor. A TAB. 7 mostra algumas propriedades do carbono amorfo, grafite e diamante (DAMASCENO et al., 2000).

TABELA 7 - Propriedades do diamante, carbono amorfo e grafite.

\begin{tabular}{|c|c|c|c|}
\hline & Diamante & Carbono Amorfo & Grafite \\
\hline Estrutura cristalina & $\begin{array}{c}\text { Cúbica } \\
a=3,567 \AA\end{array}$ & $\begin{array}{c}\text { Amorfa, mistura de } \\
\text { hibridações } \mathrm{sp}^{3} \text { e } \mathrm{sp}^{2}\end{array}$ & $\begin{array}{c}\text { Hexagonal } \\
\mathrm{a}=4,7 \AA \text { e } \mathrm{a}=6,79 \AA\end{array}$ \\
\hline Densidade $\left[\mathrm{g} / \mathrm{m}^{3}\right]$ & 3,51 & $1,8-2,0$ & 2,26 \\
\hline Estabilidade química & $\begin{array}{l}\text { Inerte, ácidos } \\
\text { inorgânicos }\end{array}$ & $\begin{array}{c}\text { Inerte, ácidos e } \\
\text { solventes inorgânicos }\end{array}$ & $\begin{array}{l}\text { Inerte, ácidos } \\
\text { inorgânicos }\end{array}$ \\
\hline $\begin{array}{c}\text { Dureza (Vickers } \\
\left.\qquad \mathrm{Kg} / \mathrm{mm}^{2}\right)\end{array}$ & $7000-10000+$ & $900-3000$ & -------- \\
\hline Índice de refração & 2,24 & $1,8-2,2$ & $2,15(\| c) ; 1,8(\perp c)$ \\
\hline Transparência & UV - VIS - IR & VIS - IR & Opaco \\
\hline Gap ótico [eV] & 5,5 & $2,0-3,0$ & ------- \\
\hline Resistividade $[\Omega \mathrm{cm}]$ & $10^{6}$ & $10^{10}-10^{13}$ & $0,4(\| c) ; 3,28(\perp c)$ \\
\hline Constante dielétrica & 5,7 & $\begin{array}{c}4-9 \\
a-C 1-90\end{array}$ & $2,6(\| c) ; 3,28(\perp)$ \\
\hline$\% s p^{3}$ & 100 & $\begin{array}{l}\text { a-C:H, duro } 30-60 \\
\text { a-C:H, macio } 50-80\end{array}$ & 0 \\
\hline$\% \mathrm{H}$ & ----- & $\begin{array}{c}\text { a-C } 0 \\
\text { a-C:H, duro } 10-40 \\
\text { a-C:H, macio } 40-65\end{array}$ & ---- \\
\hline
\end{tabular}




\subsubsection{Tensão interna}

Durante a deposição de filmes tipo DLC ocorre a manifestação do aumento da tensão interna que é de origem compressiva. Para determinar estes tipos de tensões em filmes DLC utilizamos a fórmula de Stoney (DAMASCENO et al., 2000):

$$
\sigma=\frac{E h^{2}}{6(1-v)} \frac{1}{t}\left(\frac{1}{R_{f}}-\frac{1}{R_{i}}\right)
$$

onde para filmes tipo DLC dopados com Si, E é o módulo de Young do Si (equivalente a 112,4 GPa), v é a razão de Poisson do Si $(0,42)$, t é a espessura do filme, Ri e Rf são os raios de curvatura inicial e final do substrato respectivamente e $\mathrm{h}$ é a espessura do substrato. Esta fórmula tem validade só quando a tensão no filme não excede o limite plástico.

A tensão interna nos filmes desenvolve-se durante o seu processo de formação, com aumento a espessura. As causas da formação de tensões nos filmes podem ser variadas. Seja por causa da diferença entre os coeficientes de expansão térmica do filme e do substrato, por causa de tensões intrínsecas devidas à presença de impurezas, de um ordenamento estrutural incompleto ou por reordenamento estrutural. Qualquer mecanismo que impeça o rearranjo atômico permitirá o desenvolvimento de tensões internas elevadas. A tensão interna não é função da espessura do filme e pode ser medida pela técnica de deflexão do substrato ou por medidas de difração de Raios-X, este último no caso de amostras cristalinas ou policristalinas que não faz parte do presente trabalho.

O problema principal dos filmes de a-C:H é que eles geralmente têm uma substancial tensão intrínseca. Isto limita a aderência dos filmes mais espessos em alguns substratos onde não é formado uma camada adesiva, como no caso do silício, em que é formada uma camada de SiC na interface. O problema de aderência adesiva de filmes finos acontece quando a tensão interna excede a um valor crítico. A aderência é uma medida empírica no teste de ranhura com uma ponta de agulha através de aumento contínuo de força normal até que o filme começa a descolar para uma dada carga, chamada de carga crítica. As tensões maiores são observadas nos filmes DLC ricos em ligações 
tetragonais. Estas tensões decrescem nos filmes com características do grafite, onde predominam ligações trigonais, e em filmes poliméricos, ricos em hidrogênio, o que ajuda a reduzir as distorções nas ligações trigonais e tetraédricas (ROBERTSON, 2003).

\subsubsection{Nanoindentação em filmes DLC}

A dureza elevada está relacionada a altas energias de coesão, comprimentos curtos de ligações químicas e a um alto grau de ligações covalentes (ROBERTSON, 2003). A dureza de um material, além de estar determinada pela magnitude das forças de interação, também está determinada pelos mecanismos de deformação. Portanto, o valor da dureza pode variar com a microestrutura e com outros constituintes estruturais como impurezas, defeitos e vazios.

Geralmente, as medidas de dureza em filmes finos são feitas com testes de nanoindentação. Este teste mede a resistência do material às deformações mecânicas através da sua superfície. A nano dureza tem relação com as propriedades plásticas, que determinam de que modo e o quanto um material sólido é deformado pelo efeito da aplicação de uma força perpendicular à superfície através de um penetrador feito de um material duro, como por exemplo, o diamante. Quanto menor a deformação permanente verificada, maior o valor da dureza $\mathrm{H}$.

O módulo de elasticidade se relaciona com as propriedades responsáveis pela capacidade de recuperação da forma original do material. Uma superfície que tenha sido submetida a um penetrador apresenta uma determinada capacidade de recuperação durante o descarregamento. Quanto menor a recuperação, maior é a rigidez do material, e maior é o seu módulo de elasticidade E. Nas últimas décadas, as técnicas utilizadas para medir essas grandezas em filmes finos e superfícies modificadas têm se desenvolvido muito (OLIVER e PHARR, 1992; CHEN et al., 2011).

\subsubsection{Módulo de elasticidade em filmes DLC}

Muitas das propriedades mecânicas dos filmes DLC são medidas pelo método de nanoindentação, utilizando uma ponta de diamante com a medição de 
uma curva força versus profundidade de penetração a partir da superfície da amostra. A FIG. 36 traz a dependência da variação do Módulo de Young com a Tensão de polarização, que assume máximo valor para uma tensão de $100 \mathrm{~V}$.

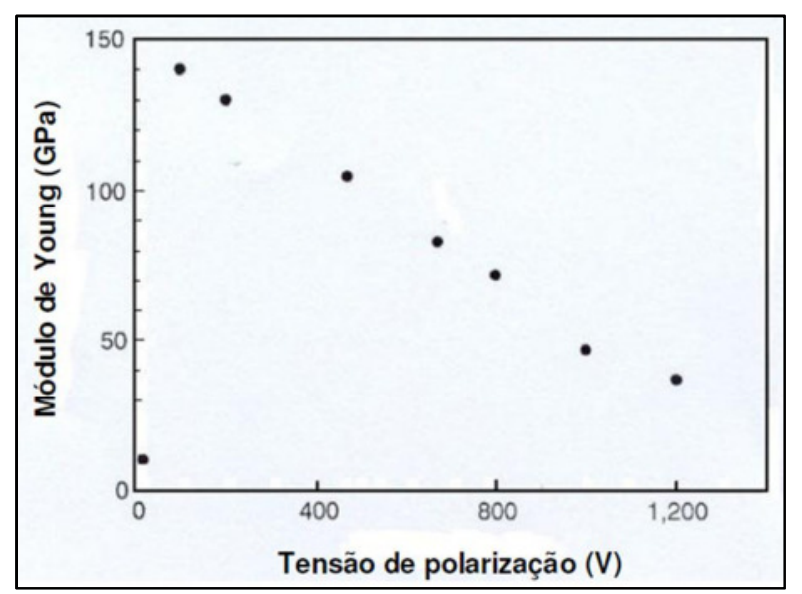

FIGURA 36 - Variação do Módulo de Young com tensão de polarização para um a-C:H depositado do metano (ROBERTSON, 2002).

A FIG. 37 mostra como se dá de dependência do Módulo de Young com a densidade.

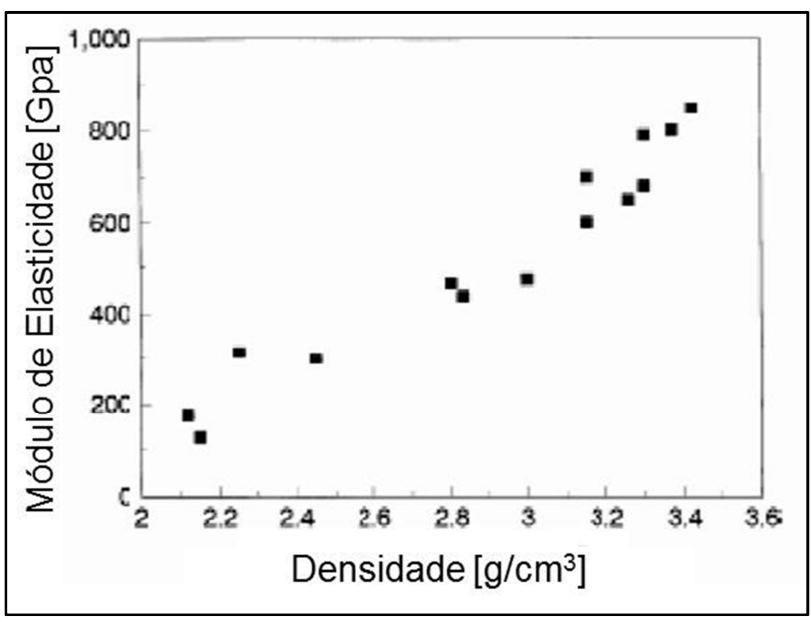

FIGURA 37. Variação do Módulo de Young com a densidade (ROBERTSON, 2002).

Pela análise das FIG. 36 e 37, chegar-se-á a conclusão que existe uma forte relação entre densidade e tensão de polarização. 
A TAB. 8 traz um resumo das características mecânicas para filmes com diversas composições e processos de deposição.

TABELA 8 - Propriedades Mecânicas do DLC

\begin{tabular}{|c|c|c|c|c|c|c|c|}
\hline $\begin{array}{l}\text { Tipo de } \\
\text { filme }\end{array}$ & Código & $\begin{array}{c}\text { Gás } \\
\text { precursor }\end{array}$ & $\begin{array}{l}\text { Método de } \\
\text { deposição }\end{array}$ & $\begin{array}{c}\text { Dureza } \\
\text { [GPa] }\end{array}$ & $\begin{array}{c}\text { Módulo de } \\
\text { Elasticidade } \\
\text { [GPa] }\end{array}$ & $\begin{array}{c}\text { Densidade } \\
{\left[\mathrm{kg} / \mathrm{m}^{3}\right]}\end{array}$ & $\begin{array}{c}\text { Tensões } \\
\text { internas } \\
\text { [GPa] }\end{array}$ \\
\hline \multirow{6}{*}{ DLC } & $\mathrm{a}-\mathrm{C}: \mathrm{H}$ & - & - & $10,5-14$ & $95-130$ & - & $1,5-3,5$ \\
\hline & $\mathrm{a}-\mathrm{C}: \mathrm{H}$ & $\mathrm{CH}_{4}$ & PACVD & $11-33$ & $90-222$ & $>12$ & - \\
\hline & $\mathrm{a}-\mathrm{C}: \mathrm{H}$ & - & $\begin{array}{l}\text { PACVD } \\
\text { Sputtering }\end{array}$ & $7-14$ & $35-136$ & $1,7-1,8$ & - \\
\hline & $\mathrm{a}-\mathrm{C}: \mathrm{H}$ & & rf-PACVD ${ }^{4}$ & $33-35$ & 200 & $1,6-1,8$ & - \\
\hline & $\mathrm{a}-\mathrm{C}: \mathrm{H}$ & $\mathrm{C}_{2} \mathrm{H}_{2}$ & PACVD & $5-40$ & - & - & - \\
\hline & $\mathrm{a}-\mathrm{C}: \mathrm{H}$ & $\mathrm{C}_{2} \mathrm{H}_{2}, \mathrm{C}_{2} \mathrm{H}_{4}$ & CVD & $7-20$ & - & $>2$ & $1-6$ \\
\hline $\begin{array}{c}\text { DLC } \\
\text { Diamante }\end{array}$ & - & - & CVD & $31-90$ & $250-1050$ & - & $380-500$ \\
\hline $\begin{array}{c}\text { DLC } \\
\text { natural }\end{array}$ & - & - & - & $55-113$ & $900-1250$ & - & - \\
\hline
\end{tabular}

Fonte - VICENTE, 2005; CHARITIDIS, 2010; BEWILOGUA et al., 2009.

\subsubsection{Propriedades tribológicas dos filmes DLC}

As propriedades de atrito e desgaste dos filmes DLC são afetadas pelas propriedades do filme, pelo ambiente ao qual esta sendo aplicado e pelos parâmetros tribológicos utilizados (HOLMBERG e MATTHEWS, 1994; GANGOPADHYAY, 1998 apud RONKAINEN, 2001).

De forma geral, os filmes DLC podem ser considerados como filmes de baixo atrito quando comparados com outras soluções que tem mesma finalidade, como é o caso dos revestimentos cerâmicos a base de TiN. De acordo com analises realizadas por RONKAINEN et al. (1992), o TiN apresentou valores de COF ao redor de 0,5 quando submetido a teste de bancada de contato contra um corpo de prova de aço, enquanto que o filme DLC apresentou valores de COF inferiores à 0,2 , sendo ambos as analises realizadas em condições normais de temperatura e pressão.

\footnotetext{
${ }^{4}$ rf-PACVD: deposição química a vapor assistida por plasma com rádio frequência.
} 
Recentemente GRILL (1999a) e JARRAT et al.(2003) demonstraram que em todos os meios o comportamento tribológico do filme de DLC é controlado por uma camada de transferência formada durante a fricção.

Quando um material é liberado de uma superfície, por desgaste ou abrasão, ele pode ficar solto na interface das superfícies deslizantes ou ainda se unir a uma das faces (a que não possui o recobrimento) formando assim a camada de transferência. Esta geralmente altera as propriedades tribológicas da superfície que a recebeu, como mostra a FIG. 38, mudando as características tribológicas das superfícies deslizantes, já que um novo par de materiais se formou.

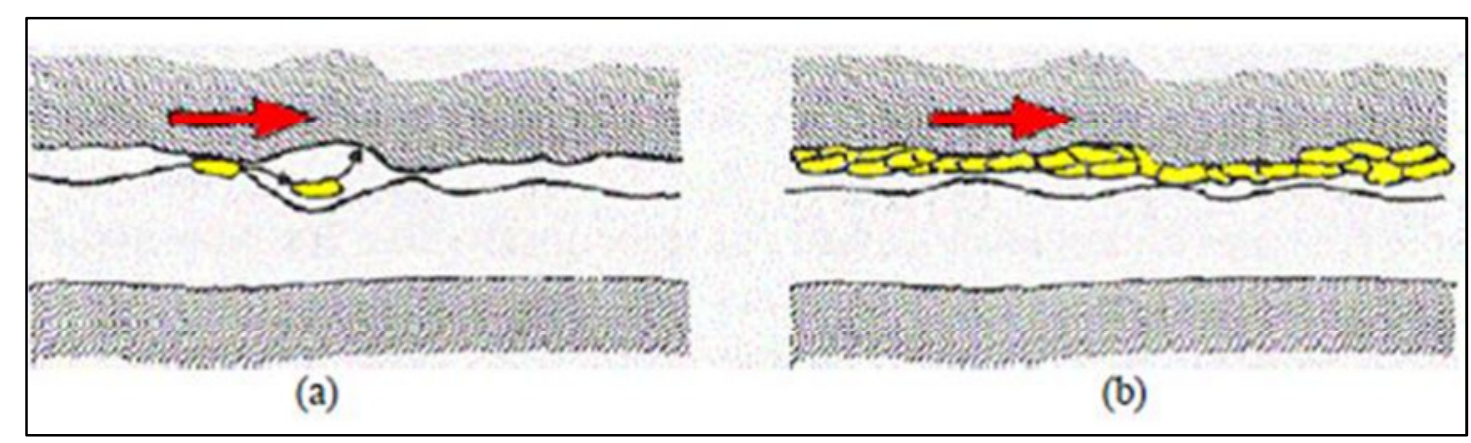

FIGURA 38 - Formação da camada de transferência a) material que se soltou de uma das superfícies; b) material se aderindo a outra superfície (HOLMBERG e MATTHEWS, 1994).

LIU et al. (1996) demonstraram pelo método Raman que a camada de transferência é semelhante ao carbono hibridizado $\mathrm{sp}^{2}$ (grafite). Os autores argumentam que a formação da camada de transferência é devido ao desprendimento de hidrogênio da superfície, causado pelo aquecimento localizado devido a fricção, desestabilizando as ligações $\mathrm{sp}^{3}$. Sob uma determinada carga, uma deformação por cisalhamento pode ocorrer, transformando as ligações $\mathrm{sp}^{3}$ (típicas do diamante) em $\mathrm{sp}^{2}$ (típicas do grafite).

Já GRILL (1997) afirma que tal camada de transferência é formada pela transformação induzida por atrito da camada mais superficial do filme DLC em um material de baixa tensão de cisalhamento. Essa transformação que ocorre durante o atrito, pode ser o resultado do aquecimento resultante, causado por efeitos térmicos e de esforços gerados durante o deslizamento. A resistência ao 
cisalhamento da camada de transferência e sua adesão às superfícies deslizantes podem ser afetadas pelo meio, pela carga de contato e pela velocidade do deslizamento. Sendo assim, o hidrogênio pode favorecer a formação da camada de transferência e seu efeito lubrificante, porém a água e o oxigênio podem restringi-los.

Os valores encontrados por DONNET e GRILL (1997) para o COF do DLC no vácuo variava de 0,007 a 0,4 enquanto que no ar ambiente em uma umidade relativa de $20 \%<\mathrm{RH}<60 \%$ variou de 0,05 a 1,00. Entretanto, o mais comum é que esses valores oscilem entre 0,007 a 0,02 no vácuo e 0,1 a 0,4 em ar ambiente. Essas alterações no valor do coeficiente de fricção são causadas pelas variações na estrutura e composição dos filmes (GRILL, 1999b). Não se encontrou na base de dados valores de medição de COF para filmes a-C:H:Si amorfos em ambientes lubrificados a alta temperatura.

Devido à proposta de aplicação do filme DLC deste trabalho ser em ambiente lubrificado em alta temperatura, acima de $100^{\circ} \mathrm{C}$, é extremamente interessante se conhecer o comportamento deste filme nesta condição. Testes realizados com a-C:H e ta-C em condições a seco e lubrificadas, revelaram que para o primeiro tipo de revestimento a passagem de seco a lubrificado não trouxe ganhos significativos, YASUDA et al. (2003). Os coeficientes de atrito passaram de aproximadamente 0,15 a 0,1. Já para o DLC sem hidrogênio foi obtido um coeficiente de atrito numa situação lubrificada de 0,06, não sendo realizados ensaios em condições a seco. O trabalho cita o grande potencial do filme ta-C para a diminuição do atrito e sugere que molhabilidade do filme a-C:H é menor que a do ta-C, devido a interação do hidrogênio com os aditivos do óleo.

A tensão de polarização tem papel importante sobre o COF, pois o seu aumento induz a um maior bombardeamento de íons sobre o filme em crescimento que leva à formação de uma rede mais densa pelo aumento de ligações cruzadas com mais ligações $\mathrm{sp}^{2}$ e significativamente menos hidrogênio contido e menos hidrogênio ligado.

A temperatura de ensaio afeta a difusão do hidrogênio, de modo que o aumento da temperatura durante o ensaio causa uma diminuição do coeficiente de atrito DONNET et al. (2000).

A TAB. 9 traz valores típicos de COF encontrados em diversas publicações. 
TABELA 9 - Relação de COF para filmes DLC

\begin{tabular}{ccccc}
\hline $\begin{array}{c}\text { Processo de } \\
\text { deposição }\end{array}$ & Filme & Tribômetro & $\begin{array}{c}\text { Atmosfera / } \\
\text { condição }\end{array}$ & $\begin{array}{c}\text { Coeficiente de } \\
\text { atrito }\end{array}$ \\
\hline CVD & a-C:H & Esfera sobre disco & Seca & 0,2 \\
CVD & a-C:H & Esfera sobre disco & Lubrificada óleo & 0,05 \\
CVD & W-C:H & Esfera sobre disco & Seca & 0,2 \\
rf-PACVD & a-C:H & Pino sobre disco & Vácuo & $0,006-0,04$ \\
rf-PACVD & a-C:H & Pino sobre disco & Ambiente (50\% \\
umidade) & 0,2 \\
PVD & ta-C & Pino sobre disco & Ambiente (50\% \\
umidade) & 0,12 \\
PACVD & a-C:H & Esfera sobre disco & Seca \\
PACVD & a-C:H & Eulticamadas & 0,05 \\
CVD & a-C:H & Pino sobre disco & Ambiente (50\% & 0,2 \\
CVD & a-C:H & Pino sobre disco & Lubrificada óleo & 0,15 \\
PVD & ta-C & Pino sobre disco & Lubrificada óleo & 0,065 \\
\hline
\end{tabular}

Fonte-ERDEMIR, 2001; VERCAMMEN et al., 2000; GRILL, 1993; DREES et al. , 2004.

\subsubsection{Resistência ao desgaste}

Ao se analisar o desgaste, a primeira correlação que pode ser feita é com a dureza do filme ou superfície. Na qual, o coeficiente de desgaste é inversamente proporcional à dureza, GAHR (1987).

Pela própria natureza dos filmes DLC, pode concluir-se que a dureza aumentará como aumento das ligações $\mathrm{sp}^{3}$. Até atingir o máximo, que é valor obtido pelo diamante $(100 \mathrm{GPa})$. Partindo deste raciocínio, é de se esperar que os filmes ta-C tenham maior resistência ao desgaste que os filmes a-C:H (ROBERTSON, 2002). Sendo isto o que realmente ocorre, o desgaste no DLC se dá por dois mecanismos: 
1 - Desgaste pelo atrito ligado à rugosidade superficial.

2 - Desgaste via transferência de camadas, onde ocorre a formação de um tribofilme (camada de transferência) induzida pela pressão de contato que é a responsável pela diminuição do coeficiente de atrito, (ROBERTSON, 2002).

Existem outros fatores, tais como: dureza e rugosidade do substrato e que afetam o desgaste podendo gerar inclusive delaminações do filme DLC. Para substratos de baixa dureza ocorrem altas deformações plásticas, o revestimento frágil, não podendo acompanhá-las se rompe.

Os filmes ta-C, por apresentarem alta dureza, se não possuírem uma rugosidade adequada podem causar desgaste excessivo no contra corpo.

\subsubsection{Deposição dos filmes DLC}

Segundo DAMASCENO et al. (2002), há dois grupos de técnicas para deposição dos filmes DLC: a deposição física por vapor (PVD) e a deposição química por vapor (CVD).

O PVD ocorre sem que haja alguma reação química na superfície do substrato ou na fase gasosa. Nessa categoria estão as técnicas de evaporação (resistiva e por feixe de elétrons) e "sputtering" (colisão).

Já as técnicas CVD são feitas com a utilização de materiais voláteis que reagirão quimicamente com outros gases, produzindo um sólido não volátil, que se depositará sobre o substrato. Estas podem ser exemplificadas por técnicas a base de filamento aquecido ou por técnica de deposição química assistida por plasma (PACVD), podendo este ser gerado por rádio frequência (rf-PACVD). Dentre os precursores usados para deposição de DLC na técnica PACVD estão os hidrocarbonetos em geral (acetileno, butano, metano) silano para silício, dentre outros gases, GRILL e MEYERSON (1994).

A grande maioria das técnicas de deposição também utiliza algum tipo de bombardeamento iônico do filme durante a deposição fornecendo ao filme características de estrutura e densidade, GRILL e MEYERSON (1994).

A TAB. 10 demonstra algumas técnicas de deposição dos filmes de DLC, citando também algumas características dos filmes resultantes, de acordo com o tipo de precursor (gasoso ou sólido) envolvido no processo. 
TABELA 10 - Principais técnicas de deposição/produção dos filmes DLC amorfo e algumas de suas características.

\begin{tabular}{|c|c|c|c|c|c|}
\hline & $\begin{array}{c}\text { Pressão } \\
\text { [torr] }\end{array}$ & Gases & $\begin{array}{l}\text { Alvo } \\
\text { sólido }\end{array}$ & $\begin{array}{l}\text { Fonte de } \\
\text { impurezas }\end{array}$ & $\begin{array}{l}\text { Conteúdo } \\
\text { de H [\%] }\end{array}$ \\
\hline \multicolumn{6}{|c|}{ Processos partindo de gases hidrocarbonetos } \\
\hline PACVD & $\begin{array}{c}0,01- \\
0,5\end{array}$ & $\begin{array}{l}\mathrm{CH}_{4}, \mathrm{C}_{2} \mathrm{H}_{2} \\
\mathrm{C}_{6} \mathrm{H}_{6}, \mathrm{C}_{4} \mathrm{H}_{10}\end{array}$ & - & $\begin{array}{c}\text { Gases, paredes } \\
\text { do reator. }\end{array}$ & $\begin{array}{c}10-40 \\
\text { (duro) } \\
40-65 \\
\text { (macio) }\end{array}$ \\
\hline $\begin{array}{l}\text { Feixe (direto) } \\
\text { de íons }\end{array}$ & $\begin{array}{c}10^{-7}- \\
10^{-5}\end{array}$ & $\begin{array}{c}\mathrm{CH}_{4}, \mathrm{CO} \\
\mathrm{CO}^{2}, \mathrm{C}_{2} \mathrm{H}_{2} \\
\mathrm{C}_{4} \mathrm{H}_{10}-\mathrm{Ar}\end{array}$ & - & $\begin{array}{l}\text { Filamento, gases, } \\
\text { paredes do reator. }\end{array}$ & $0-30$ \\
\hline Íon plating & $\sim 0,1$ & $\mathrm{C}_{6} \mathrm{H}_{6}$ & - & $\begin{array}{c}\text { Grades, gases, } \\
\text { paredes do reator. }\end{array}$ & $<1$ \\
\hline Arco & $\sim 0,75$ & - & - & $\begin{array}{c}\text { Gases, paredes } \\
\text { do reator. }\end{array}$ & $\sim 1$ \\
\hline \multicolumn{6}{|c|}{ Processos partindo de carbono sólido } \\
\hline Sputtering & $<5 \times 10^{-3}$ & $\begin{array}{c}\mathrm{Ar}, \mathrm{Ar}^{+} \mathrm{H}_{2} \\
\mathrm{Ar}^{+} \mathrm{CH}_{4}\end{array}$ & Grafite & $\begin{array}{l}\text { Gases, paredes } \\
\text { do reator, alvo. }\end{array}$ & $<9$ \\
\hline $\begin{array}{l}\text { Sputtering por } \\
\text { feixe de íons }\end{array}$ & $<10^{-3}$ & $\mathrm{Ar}, \mathrm{Ar}^{+} \mathrm{H}_{2}$ & Grafite & $\begin{array}{l}\text { Gases, paredes } \\
\text { do reator, alvo. }\end{array}$ & $<1$ \\
\hline Laser ablation & $<10^{-6}$ & - & Grafite & $\begin{array}{l}\text { Gases, paredes } \\
\text { do reator, alvo. }\end{array}$ & $<1$ \\
\hline Arco sob vácuo & $<10^{-4}$ & - & Grafite & Alvo & $<1$ \\
\hline
\end{tabular}

Fonte - DAMASCENO et al., 2002.

\subsubsection{Técnicas PACVD}

PACVD pode ser definido como um processo em que cada um dos constituintes da fase de vapor reage na forma de filme com a assistência de uma descarga elétrica. Neste processo as moléculas do gás de trabalho são dissociadas pelo impacto de uma descarga elétrica, formando espécies muito reativas que podem ser neutras, iônicas ou radicais. 
Estas espécies reagem no substrato de forma iônica ou por mecanismo de radicais livres na formação do filme. Os filmes podem depositados em temperaturas abaixo de $300^{\circ} \mathrm{C}$.

Os processos CVD assistidos por plasma são os mais comumente utilizados. Numa câmara a vácuo as peças são depositadas sobre um suporte condutor, que faz o papel de cátodo. Um gás hidrocarboneto é introduzido dentro da câmara e submetido a descargas elétricas (rádio frequência, micro-ondas, corrente direta, etc). As descargas quebram as moléculas do gás que produz os átomos de carbono que se depositarão sobre a superfície das peças. O processo PACVD não é direcional e permite tratar superfícies complexas.

No caso dos filmes tipo DLC, são usados como gases precursores para a deposição o $\mathrm{CH}_{4}, \mathrm{C}_{2} \mathrm{H}_{2}, \mathrm{C}_{2} \mathrm{H}_{4}$ e $\circ \mathrm{C}_{6} \mathrm{H}_{6}$. A FIG. 39 mostra o esquema de um reator PACVD.

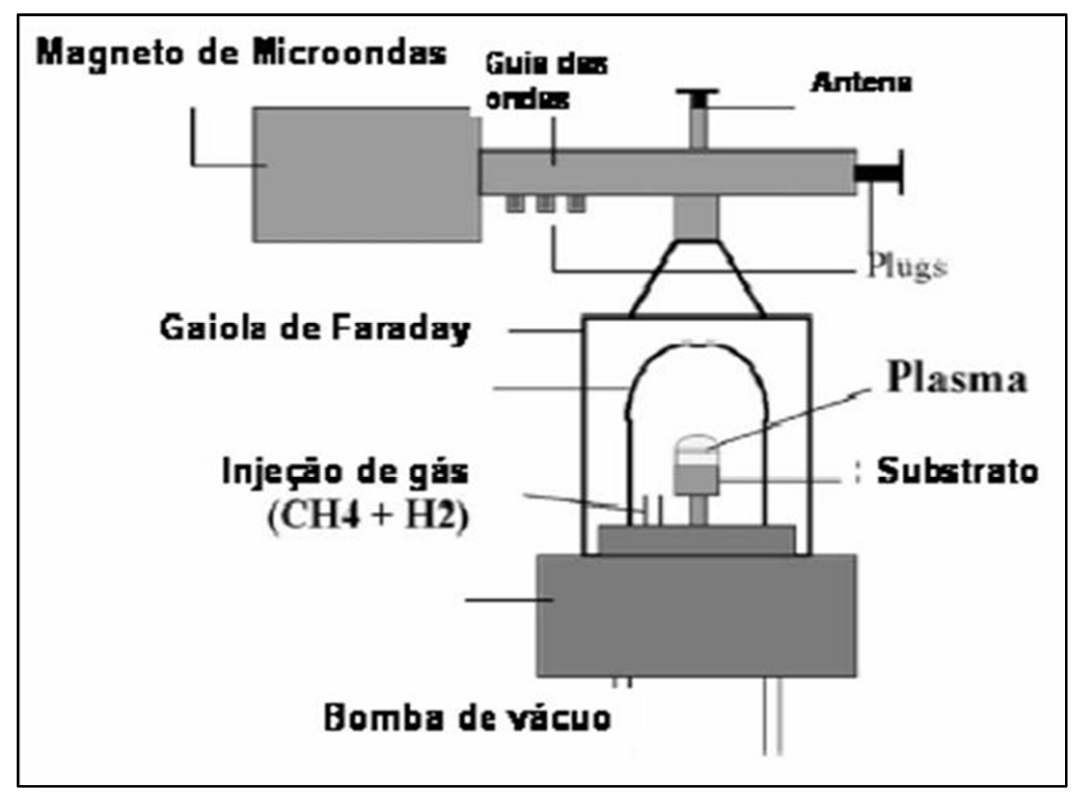

FIGURA 39 - Esquema de reator PACVD assistido por micro-ondas (CHOY, 2003).

\subsubsection{Espectroscopia de espalhamento Raman}

A técnica de espectroscopia de espalhamento Raman tem sido largamente utilizada na caracterização de materiais à base de carbono, ou carbonosos. Com recursos de microfocalização, as investigações são bastante precisas, identificando as diferentes formas cristalinas e amorfas que podem 
compor as amostras. De acordo com as suas possíveis aplicações, uma precisa caracterização dos materiais carbonosos se faz necessária, de preferência por métodos não destrutivos, com análises não somente quanto a sua heterogeneidade, mas também quanto a sua forma estrutural (FERRARI, 2008).

Os espectros Raman são sensíveis à perturbação da simetria de translação, como ocorre em pequenos cristais e, como tal, é particularmente útil na análise de desordem e formação de cristalitos em materiais DLC.

As variáveis que levam a alterações nos espectros são: o percentual de hidrogênio $(\% \mathrm{H})$; a razão entre ID/IG, onde ID é a intensidade do pico $D$ (Desordem) e IG é a intensidade do pico G (Grafite); a posição do pico $G$ (pos-G) e a largura à meia altura da curva G (FWHM) (SCHARF e SINGER, 2003).

A FIG. 40 apresenta um espectro Raman onde são apresentadas as influências das ligações $\mathrm{sp}^{3}$ no deslocamento da banda $\mathrm{G}$. Também é possível identificar a variação de desordem das cadeias através da intensidade do pico na banda D.

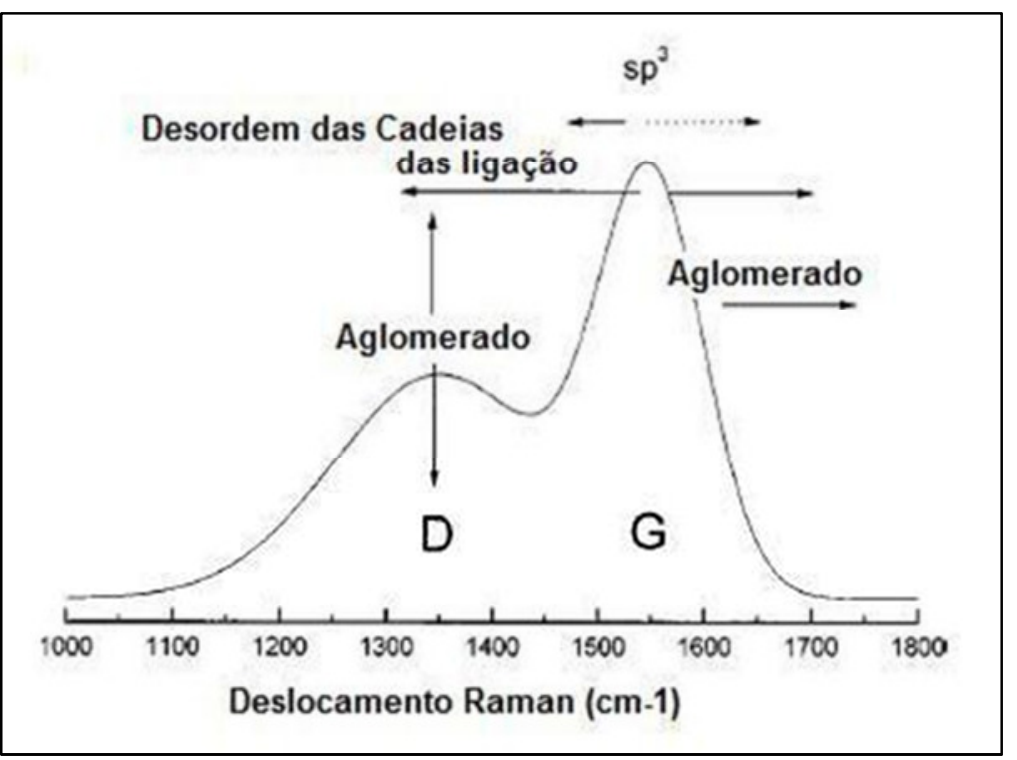

FIGURA 40 - Influências das ligações $\mathrm{sp}^{3}$ no espectro Raman, (FERRARI e ROBERTSON, 2000).

CASIRAGHI et al. (2005) mostraram em seus estudos que os revestimentos de DLC apresentam centralização da banda D em torno de 1360 $\mathrm{cm}^{-1}$ e $\mathrm{G}$ em torno de $1560 \mathrm{~cm}^{-1}$. Tais incidências funcionam como uma identidade do DLC e permitem identificar aspectos importantes do revestimento, como: a 
relação das intensidades ID/IG; alterações estruturais decorrentes da degradação do revestimento, etc,.

Os espectros Raman de todos os materiais carbonosos exibem picos característicos na região entre 1000 e $1800 \mathrm{~cm}^{-1}$ para energia de excitação no visível e infravermelho. Para os materiais grafíticos, essa região é referente às bandas $D, G$ e $D^{\prime}$, onde a banda $G\left(1500\right.$ a $\left.1600 \mathrm{~cm}^{-1}\right)$ é um modo de primeira ordem com simetria $E_{2 g}$ e as bandas D (1200 a $\left.1400 \mathrm{~cm}^{-1}\right)$ e D' $\left(1600-1630 \mathrm{~cm}^{-1}\right)$ surgem devido a processos Raman de dupla ressonância. Estudos prévios têm mostrado que essas bandas sofrem dispersão com a mudança do comprimento de onda da excitação laser, ou seja, as bandas D e D' variam sua posição no espectro (LOBO et al., 2005). THOMSEN e REICH (2000) explicaram a dispersão da banda $\mathrm{D}$ por tais processos de dupla ressonância. Processos Raman de dupla ressonância são conhecidos como processos de segunda ordem e proporcionam um aumento ressonante da intensidade Raman, por meio de dois processos de espalhamento consecutivos, sendo um elástico devido a um defeito e, o outro, de emissão (ou absorção) inelástica (THOMSEN e REICH, 2000; BALAGURA e IVANOV, 1987). Vale ressaltar que o termo segunda ordem se refere ao fato de serem dois eventos de espalhamento. Em processos de espalhamento de segunda ordem, um elétron com momento inicial $k$ é (a) primeiro excitado a energia $E i(k)$ pelo fóton incidente, (b) espalhado ao estado $k+q,[E(k+q)]$ e (c) então análise ao estado $\mathrm{k}$, [Ef(k)], e finalmente (d) recombinado com um buraco para fornecer o fóton espalhado. A dupla ressonância ocorre quando, tanto os estados intermediários, quanto o inicial (ou final), são estados eletrônicos reais (SAITO et al., 2002). Os estudos de dupla ressonância são geralmente efetuados em torno do ponto $\mathrm{K}$ da primeira Zona de Brillouin do grafite 2D. Se a energia do laser aumenta, aumenta $\mathrm{o}$ valor do vetor de onda $\mathrm{k}$ do elétron excitado $\mathrm{e}$ consequentemente do vetor de onda $q$ do elétron. É por esse motivo que a frequência de $D$ muda ou, em outras palavras, temos um ramo de fônon dispersivo. $A$ banda $D$ surge a partir de processos que ocorrem na região do ponto $\mathrm{K}$, mas a banda $\mathrm{D}^{\prime}$ surge de processos que ocorrem próximos ao ponto $\Gamma$ (GRUNEIS et al., 2002; SAITO et al., 2002). A origem das bandas D e D' em materiais carbonosos também têm sido comumente atribuídas como característica de desordem induzida devido ao efeito de distorção na rede ou do tamanho finito de partículas, ou seja, do tamanho do domínio planar do cristal de grafite (LIU et 
al., 1997; NEMANICH e SOLIN, 1979). Para filmes de diamante, um pico muito bem definido pode ser visto em $1332 \mathrm{~cm}^{-1}$, referente às ligações do tipo $\mathrm{sp}^{3} \mathrm{e}$ bandas de 1355 a $1550 \mathrm{~cm}^{-1}$, referentes à presença de grafite desordenado e carbonos amorfos (ETZ et al., 2001). Já, os espectros Raman de DLC consistem em bandas largas, típicas de materiais amorfos, desordenados (FERRARI e ROBERTSON, 2000; FERRARI e ROBERTSON, 2001).

A espectroscopia Raman também pode ser utilizada para estimar o conteúdo de hidrogênio nos filmes de DLC. A presença do hidrogênio nos filmes de DLC é visível no espectro Raman pelo aumento da fotoluminescência. Ocorrendo, geralmente, para concentrações de hidrogênio maiores que $15 \%$.

A correlação do percentual de hidrogênio no filme de DLC proposta por CASIRAGHI et al. (2005) é baseada na inclinação da linha de base do espectro Raman, que aparece devido à fotoluminescência do hidrogênio utilizando o laser de $514 \mathrm{~nm}$. A equação de correlação do percentual de Hidrogênio é dada pela equação 9:

$$
H(\% \text { at. })=21,7+16,6 \log \left(\frac{m}{I(g)}\right)
$$

onde $\mathrm{m}$ é a inclinação da linha de base (coeficiente angular de uma reta) do espectro entre 1050 e $1800 \mathrm{~cm}^{-1}$ e I (G) a intensidade do pico G.

Os revestimentos de carbono podem apresentar diversos defeitos em sua estrutura, assim como sofrer alterações devido a fenômenos triboquímicos.

FERRARI e ROBERTSON (2000) concluíram em seus estudos que o espectro Raman do DLC depende de fatores como:

(1) Aglomerações de fase $\mathrm{sp}^{2}$;

(2) desordem das ligações;

(3) presença de anéis ou cadeias $\mathrm{sp}^{2}$;

(4) relação $\mathrm{sp}^{2} / \mathrm{sp}^{3}$.

Estes autores desconsideraram o efeito do hidrogênio e concluíram que a forma do espectro é afetada por estes fatores em um efeito chamado de 
"trajetória de amorfização", que ocorre em três etapas indo do grafite para o ta-C (ou diamante) como apresentado na FIG. 41.

No esquema proposto por FERRARI e ROBERTSON (2000) verificamse a transição do carbono em função da posição $G$ e da relação ID/IG.

Os estágios mencionados são apresentados a seguir:

(1) Grafite $\rightarrow$ Grafite nanocristalino (nc-G);

(2) Grafite nanocristalino (nc-G) $\rightarrow$ Carbono amorfo (a-C);

(3) Carbono amorfo (a-C) $\rightarrow$ Carbono tetragonal amorfo (ta-C).

O esquema da FIG. 41 sugere ainda que as mudanças no espectro Raman não sejam coordenadas pelo aumento de $\mathrm{sp}^{3}$, mas sim pela evolução de aglomerados $\mathrm{sp}^{2}$.

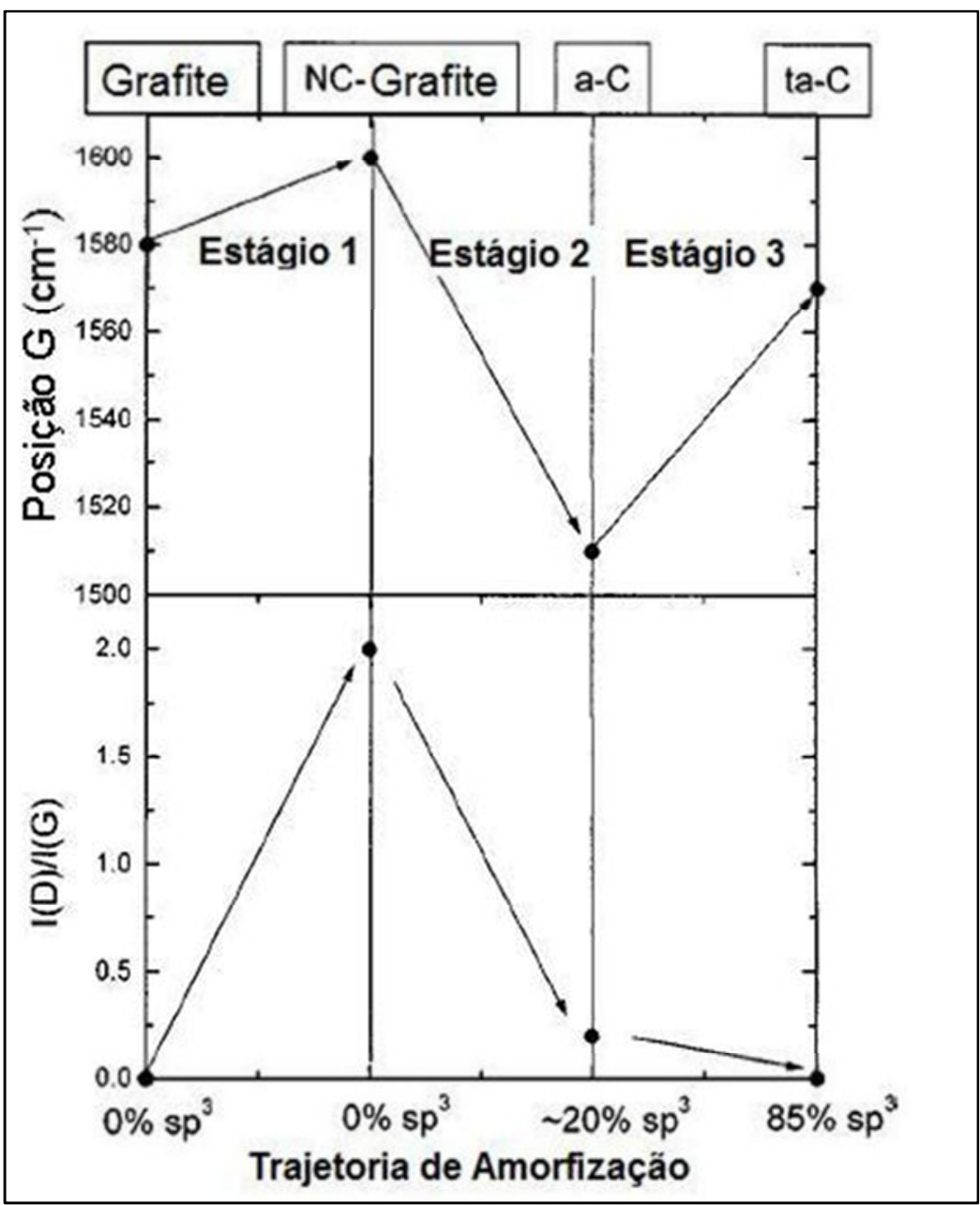

FIGURA 41 - Trajetória de amorfização, (FERRARI e ROBERTSON, 2000). 


\section{MATERIAIS E MÉTODOS}

\subsection{Metodologia adotada}

A metodologia deste trabalho foi dividida em duas fases sendo a primeira denominada de "Desenvolvimento do Conceito" e a segunda como "Validação do Conceito". A fase do desenvolvimento do conceito inicia-se com a obtenção de algumas camisas de cilindro brunidas que são submetidas a uma rotina de identificação e registro dimensional, que inclui medições da rugosidade do diâmetro interno por traçagem de perfil 2D, réplica da superfície e medição do erro de forma. Na sequência, as camisas de cilindro são enviadas a uma empresa externa para receber um revestimento de filme DLC pelo processo PACVD na superfície interna. As camisas são divididas em dois grupos, conforme especificação nominal da espessura do filme DLC recebida, sendo os valores nominais $2,5 \mu \mathrm{m}$ e $12,5 \mu \mathrm{m}$. Após uma pré-seleção, quatro camisas revestidas com filme DLC são selecionadas para a primeira fase do trabalho. A partir deste momento, as seguintes atividades são realizadas:

- Verificação da integridade dimensional das camisas e da superfície interna brunida após recobrimento: repetiu-se a mesma rotina de controle dimensional previamente feita nas quatro camisas e nas mesmas regiões estabelecidas antes do processo de deposição do filme DLC. Os resultados pós recobrimento obtidos foram confrontados com os resultados anteriores.

- Caracterização do filme DLC: análises por microscopia eletrônica de varredura (MEV), espectroscopia por energia dispersiva (EDS), difração de raios-X e nano dureza foram utilizadas nesta etapa. Os ensaios via MEV/EDS permitem a determinação da composição química (qualitativa e semiquantitativa) do filme DLC a partir de corpos-de-prova extraídos da seção transversal das camisas de cilindro. As analises por difração de raios- $X$ auxiliam na caracterização da morfologia do filme, neste caso o interesse é verificar se o filme possui uma estrutura amorfa, e finalmente os ensaios de nanodureza verificam as propriedades mecânicas dos filmes.

- Medição do coeficiente de atrito (COF): a partir de corpos-de-prova extraídos de camisas de cilindro com filme DLC e camisas referência, testes de bancada com movimento recíproco de contato em meio lubrificado foram executados. Os 
testes foram conduzidos em diferentes situações de carga e rotação a fim de se medir o COF e verificar as vantagens do filme DLC na redução do atrito.

- Durabilidade do filme DLC: camisas de cilindro revestidas com as duas espessuras do filme DLC foram montadas num motor ciclo Diesel para teste de durabilidade de $500 \mathrm{~h}$ instalado em banco de prova com auxílio de um dinamômetro. A meta deste teste foi mostrar o comportamento do filme DLC quando submetido a um teste de rodagem por longo período e também recomendar uma espessura para aplicação no componente em estudo.

Concluída a fase de desenvolvimento do conceito, inicia-se a fase de validação do conceito tomando como referência o valor de espessura do filme DLC recomendado. Novas amostras foram fabricadas sob o mesmo processo de deposição e procedimento de controle. A partir deste momento, as seguintes atividades foram realizadas:

- Teste de motor ciclo Otto à gasolina para medição do atrito: testes num motor ciclo Otto foram conduzidos utilizando camisas com filme DLC e camisas referência em diferentes condições de carga e velocidade. Em cada condição de operação foi medido o valor da força de atrito em função do ângulo do eixo de manivelas do motor, e a partir desses valores foi calculado um valor de pressão média de atrito efetiva (FMEP). Os valores de FMEP obtidos foram comparados para verificar as vantagens do filme DLC na redução do atrito do motor.

- Teste de motor Diesel para medição do consumo específico de combustível (BSFC): dois testes de um mesmo motor Diesel, instalado em banco de prova, foram conduzidos em sequência. A diferença entre os dois testes foi na configuração de montagem das seis camisas de cilindro, o primeiro motor utilizou somente camisas referência e o segundo somente camisas revestidas com filme DLC (2,5 $\mu \mathrm{m}$ de espessura nominal). Ambos os testes completaram 125 h em ciclo de durabilidade, mesmo ciclo feito na etapa anterior que completou 500 h, e depois foi levantada uma curva de desempenho de cada motor onde foram medidos os valores de potência e torque corrigidos as condições de pressão do nível do mar e o BSFC numa faixa de rotação de 1000 a 2000 rpm com carga máxima, ou seja, acelerador na posição máxima. Foram obtidas três medições para cada motor que geraram curvas médias e depois foram confrontadas tendo como objetivo avaliar o impacto da redução do atrito do motor com a utilização das camisas com filme DLC expresso pela redução do BMEP. Depois de 
concluídos os respectivos testes de durabilidade e desempenho, ambos os motores foram desmontados, e medições de desgaste nas camisas de cilindro e nos respectivos anéis de pistão foram feitos para avaliação do desgaste apresentado.

- Caracterização final do filme DLC: Duas camisas revestidas com filme DLC foram selecionadas para esta etapa final de caracterização, pela técnica de espectroscopia Raman, uma após 125 h de teste de motor Diesel e outra em estado novo sem uso. Corpos-de-prova foram retirados de diferentes posições das camisas de cilindro. Esta análise comparou as quantidades de ligações $\mathrm{sp}^{2} \mathrm{e}$ $\mathrm{sp}^{3}$ em cada caso para verificar a possibilidade de alteração das propriedades do filme DLC em função da exposição à temperatura do motor, contato com o óleo lubrificante e também devido ao desgaste abrasivo.

A FIG. 42 ilustra a sequência de atividades desenvolvidas nas duas fases da metodologia adotada.

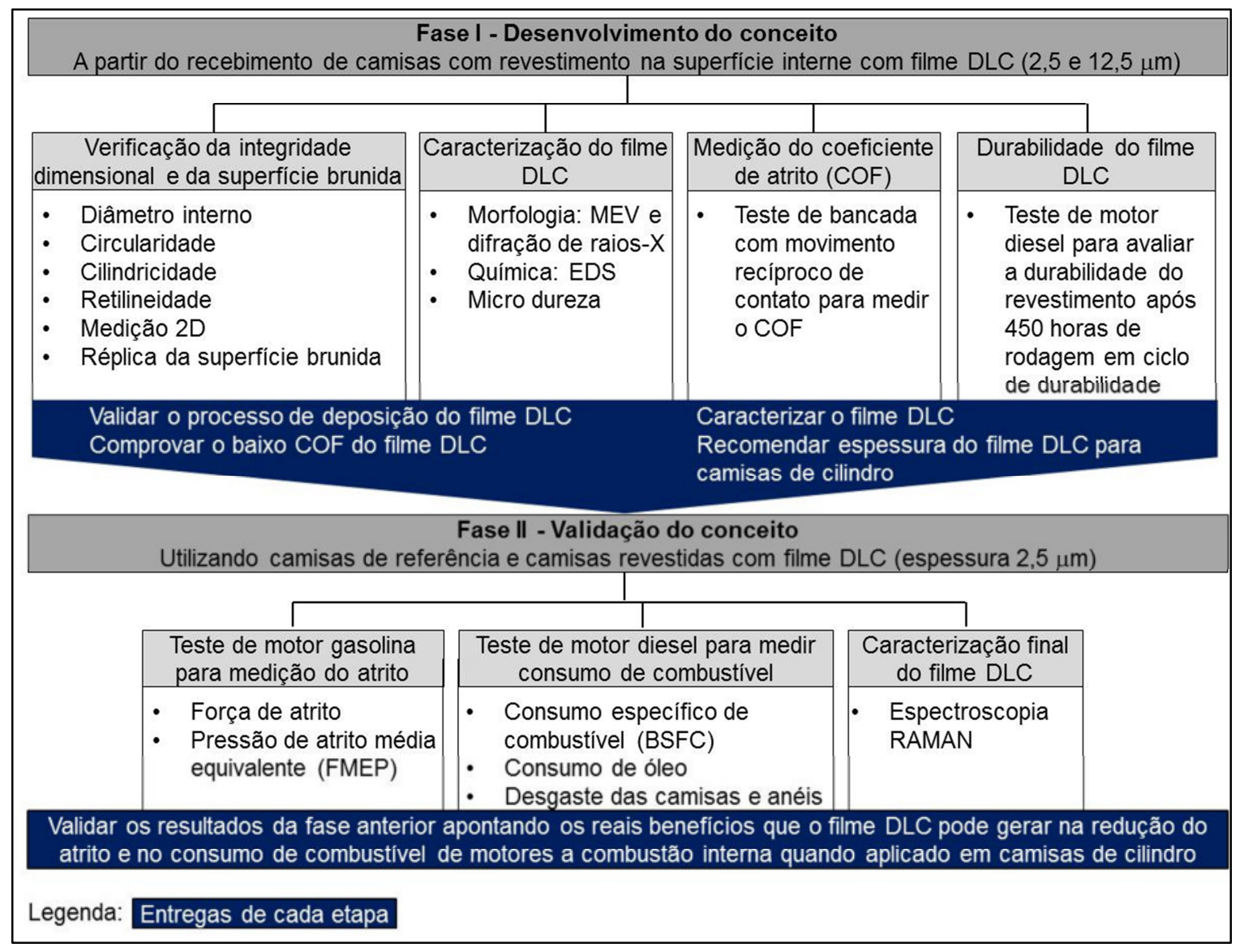

FIGURA 42 - Fluxo de atividades desenvolvidas na metodologia do trabalho. 


\subsection{Seleção das camisas de cilindro}

As camisas de cilindro utilizadas nos experimentos deste trabalho foram fabricadas em ferro fundido cinzento SAE G3000 pelo processo de fundição centrifugada. As camisas de cilindro se encontravam em condição acabada, ou seja, com a superfície interna brunida. O tipo de brunimento usado foi o "Slide honing" com ângulo de cruzamento de $55^{\circ} \pm 10^{\circ}$. A especificação dos parâmetros de brunimento seguiu a norma ISO 13565-2 / DIN 4776 e os parâmetros da série $\mathrm{Rk}$, conforme faixa de controle mostrada na TAB. 11 abaixo:

TABELA 11 - Parâmetros de brunimento das camisas de cilindro

\begin{tabular}{ccc}
\hline $\begin{array}{c}\text { Parâmetro de rugosidade conforme } \\
\text { ISO 13565-2 / DIN 4776 }\end{array}$ & Unidade & Faixa de valores \\
\hline Rpk & $\mu \mathrm{m}$ & 0,4 máximo \\
Rk & $\mu \mathrm{m}$ & $0,35-0,95$ \\
Rvk & $\mu \mathrm{m}$ & $1,40-2,80$ \\
$\mathrm{MR}_{1}$ & $\%$ & 10 máximo \\
$\mathrm{Mr}_{2}$ & $\%$ & $65-85$ \\
\hline
\end{tabular}

Para suportar as fases da metodologia do trabalho, foram utilizados dois tipos de camisas de cilindro, conforme descrito abaixo:

- Camisa de cilindro tipo molhada para aplicação em motores Diesel pesado com dimensão de $131 \times 262 \mathrm{~mm}$ (diâmetro interno vs. comprimento total) pesando aproximadamente $6,5 \mathrm{~kg}$, denominada como "camisa HD", utilizada em todos os experimentos da fase de desenvolvimento do conceito e durante a fase de validação de conceito no experimento do teste de motor Diesel para medir o consumo específico de combustível. As camisas HD com filme DLC utilizadas na etapa do desenvolvimento do conceito receberam uma identificação numérica conforme a espessura do filme DLC depositado, como mostra a TAB. 12.

- Camisa de cilindro tipo seca para aplicação em motores ciclo Otto com rosca externa M5 na parte inferior do diâmetro externo, de dimensões 96 x 133,6 $\mathrm{mm}$ (diâmetro interno vs. comprimento total), pesando aproximadamente 0,65 kg, denominada como "camisa FL" utilizada nos testes de motor para medição da força de atrito na etapa de validação do conceito. 
TABELA 12 - Relação das camisas HD

\begin{tabular}{cc}
\hline Camisa HD & Espessura nominal do filme DLC $[\mu \mathrm{m}]$ \\
\hline HD1 & 2,5 \\
HD2 & 2,5 \\
HD4 & 12,5 \\
HD6 & 12,5 \\
\hline
\end{tabular}

Foram também utilizadas camisas de cilindro de referência que apresentaram as mesmas características dimensionais, porém sem revestimento na superfície interna. A FIG. 43 mostra fotos das camisas HD e FL utilizadas no trabalho.

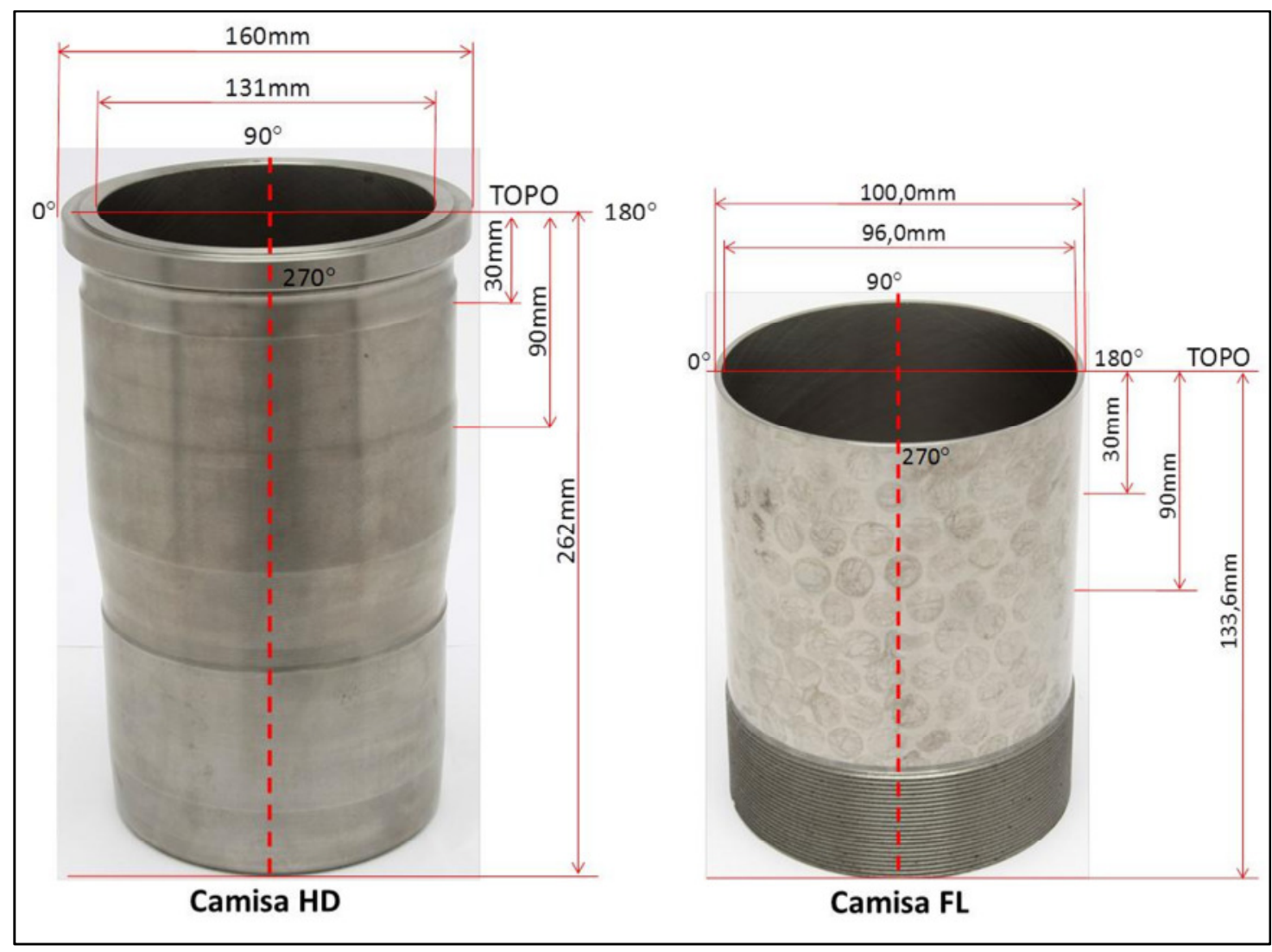

FIGURA 43 - Detalhe das camisas. (A) camisa HD, (B) camisa FL.

\subsection{Processo de deposição e características do filme DLC}

A deposição do filme DLC nas camisas de cilindro foi conduzida por uma empresa externa (Sub-One Technology), que é detentora da patente do 
processo, e já suportou uma série de trabalhos científicos como foi o os casos de LUSK et al. (2009) e REJOWSKI et al. (2012). O revestimento utilizado nos experimentos deste trabalho é um filme de carbono amorfo hidrogenado tipo diamante dopado com silício (a-C:H:Si) no inicio do processo PACVD, formando assim uma camada intermediária para melhorar a adesão ao substrato de ferro fundido. Para se obter um filme DLC homogêneo e com espessura constante sobre uma superfície interna cilíndrica, foi adotado o conceito de imersão iônica por plasma em catodo oco, também chamado "Hollow Cathode Plasma Immersion Ion Process" (HCPIIP) que utiliza a própria camisa como catodo para geração do plasma e também como câmara de vácuo da reação físico-química em vapor. Nas extremidades da camisa se conectaram os anodos. Os gases precursores para crescimento do filme DLC são conduzidos para o ambiente a vácuo (camisa de cilindro) por uma das extremidades por conta da depressão criada por uma bomba de vácuo instalada na outra extremidade da linha, responsável também, pelo controle de vazão dos gases, conforme mostra a FIG. 44.

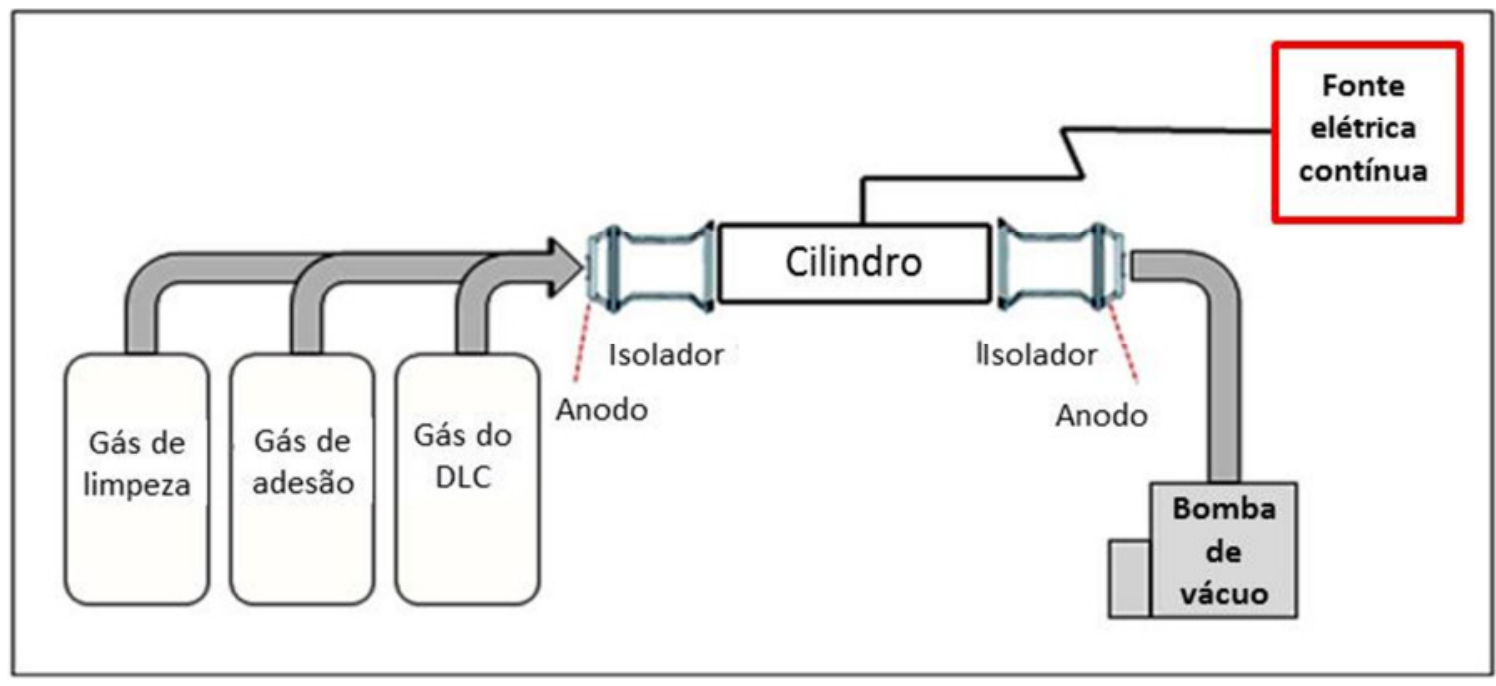

FIGURA 44 - Esquema do processo de deposição HCPIIP (REJOWSKI et al. 2012).

Desta forma, o filme DLC cresce a partir do substrato de ferro fundido, e com a introdução de $100 \%$ do precursor à base de $\mathrm{Si}$ (gás silano - $\mathrm{SiH}_{4}$ ) no inicio do processo, cria-se a camada de silício intermediária. Depois de passado um determinado período, um segundo precursor à base de hidrocarboneto (gás metano $-\mathrm{CH}_{4}$ ) é introduzido juntamente com o primeiro gás na linha, porém, com 
vazão reduzida, e tende a crescer à medida que se reduz a vazão do primeiro gás $\left(\mathrm{SiH}_{4}\right)$. A variação das vazões de ambos os gases é conduzida até se obter uma redução total do primeiro gás $\left(\mathrm{SiH}_{4}\right)$. A partir deste momento, o filme DLC a base de carbono cresce até a especificação de espessura desejada. Esta combinação de vazões de gases no inicio do processo de deposição cria na secção transversal do filme DLC um gradiente decrescente de Si e um crescente de C no sentido da superfície de trabalho da camisa de cilindro, conforme ilustra de forme esquemática a FIG. 45.

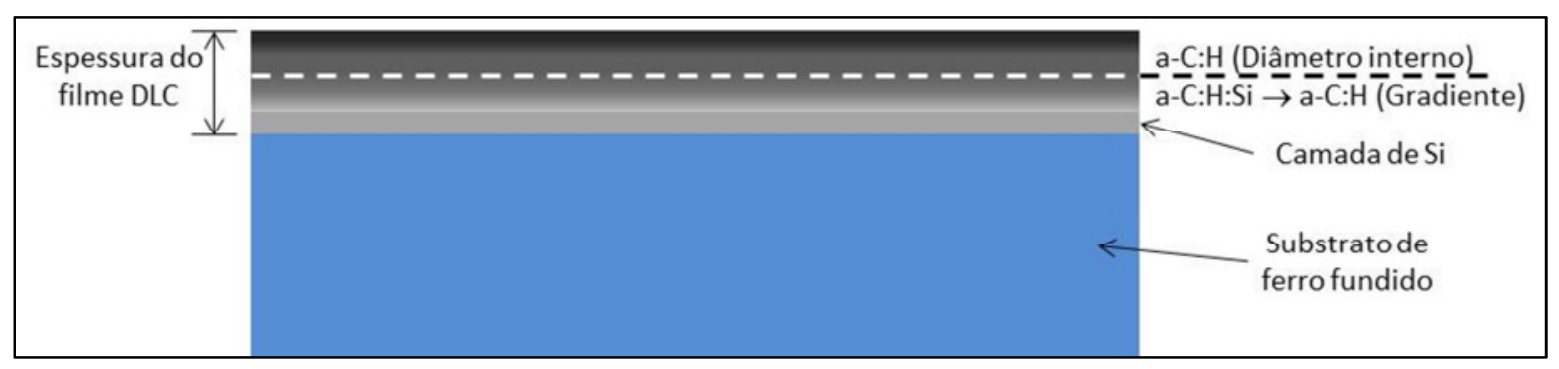

FIGURA 45 - Morfologia do filme DLC, esquematicamente.

$\mathrm{Na}$ TAB. 13, estão apresentados alguns parâmetros utilizados no processo PACVD pelo método HCPIIP, fornecidos pela empresa externa.

TABELA 13 - Características do processo PACVD

\begin{tabular}{ccc}
\hline Parâmetros do processo & Unidade & Valor \\
\hline Faixa de temperatura da reação & ${ }^{\circ} \mathrm{C}$ & $120-200$ \\
Gases de reação & & $\mathrm{CH}_{3} \mathrm{SiH}_{3} ; \mathrm{CH}_{4}$ \\
Pressão na câmara de reação & $\mathrm{Pa}$ & $9,33-16,00$ \\
Taxa de deposição & $\mu \mathrm{m} / \mathrm{min}$ & 0,5 \\
\hline
\end{tabular}

Fonte: Lusk, 2009.

A FIG. 46 ilustra uma camisa HD após receber deposição do filme DLC, evidenciando, de forma positiva, a permanência dos riscos cruzados que foram gerados pelo processo prévio de brunimento na superfície interna. 


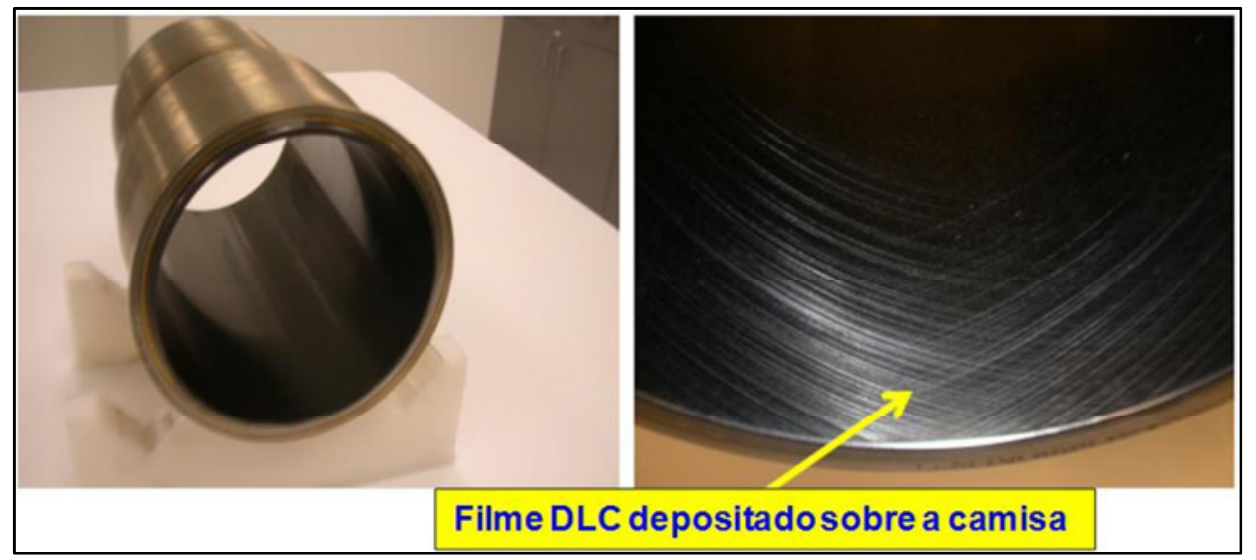

FIGURA 46 - Camisa HD com filme DLC na superfície interna.

\subsection{Controle dimensional das camisas antes e após deposição do DLC}

Todas as camisas HD foram submetidas a um controle dimensional antes e após a deposição do filme DLC, a fim de verificar se a superfície do filme DLC manteve rugosidade similar à do substrato, e se o processo de deposição causou alguma deformação nas camisas. Os seguintes controles foram realizados:

- Controle do diâmetro interno: o diâmetro interno foi controlado com auxílio de um relógio comparador milesimal com tolerância de 1,0 $\mu \mathrm{m}$. As medições foram realizadas em duas alturas no sentido axial das camisas a partir da face superior (topo), 30 e $90 \mathrm{~mm}$ respectivamente, e em dois sentidos perpendiculares, 0-180 e 90-270 . Os resultados obtidos antes e após o processo de deposição do filme DLC foram confrontados para se calcular a espessura do filme;

- Controle da circularidade, cilindricidade e retilineidade do diâmetro interno: a deformação diametral das camisas de cilindro HD foi medida pela circularidade do diâmetro interno, conhecida como deformação de 1aㅡ ordem, em doze alturas no sentido axial a partir da face de topo. A deformação longitudinal foi medida pela retilineidade axial do diâmetro interno em quatro posições angulares: $0,90,180$ e $270^{\circ}$, e pela composição dessas geratrizes, 0 equipamento erros de forma utilizado gerou as analises de cilindricidade do diâmetro interno. Utilizou-se uma máquina de erro de forma, modelo Formetester MMQ44 com tolerância de 0,100 $\mu \mathrm{m}$ e raio da ponta com 1,5 $\mu \mathrm{m}$.

- Controle da rugosidade do diâmetro interno: os valores de rugosidade foram obtidos pelo método de medição 2D Stylus suportado pelo rugosímetro portátil da 
marca MAHR, modelo Perthometer M2, acoplado a um apalpador MFW - 250 que apresenta raio de ponta de $2 \mu \mathrm{m}$ e apresenta uma tolerância de medição de 0,010 $\mu \mathrm{m}$. Conforme recomenda a norma DIN EN ISO 13565-1 (1997), se adotou um comprimento amostral de 5,6 $\mathrm{mm}$ por medição e a rotina de tratamento do perfil da superfície brunida incluiu a remoção do erro de forma da superfície e a aplicação de um filtro conforme DIN EN ISO 11562 (1998) com linha de corte ou "cut-off' de 0,8 mm para a remoção da ondulação do perfil de rugosidade. Com esta rotina, foram determinados os parâmetros $\mathrm{Ra}, \mathrm{Rz}, \mathrm{Rmax}$ e R3z. Além desses parâmetros, com base na curva de Abbott Firestone, os parâmetros Rk, Rvk, Rpk, Mr1 e Mr2 também foram determinados (DIN EN ISO 13565-2, 1997). O perfil obtido em cada medição foi analisado mediante a utilização de um software específico para perfis de rugosidade (TALY PROFILE®, versão 3.1.10 fornecido pela empresa TAYLOR HOBSON). Os parâmetros de rugosidade foram escolhidos por serem os mais utilizados para brunimento em camisas de cilindro (TOMANIK, 2000; PAWLUS et al., 2009). A média dos valores de rugosidade do brunimento, segundo os parâmetros da série Rk, é apresentada em um gráfico de barras, comparando esta característica antes e depois da deposição do filme DLC.

- Geração da réplica da superfície brunida: este tipo de controle permite uma análise qualitativa do padrão do brunimento. A réplica do brunimento gerada na folha de acetato foi analisada em um microscópio óptico (MO). Esta análise qualitativa verificou o padrão dos canais de brunimento e o ângulo de brunimento antes e após o processo de deposição do filme DLC assim como, por exemplo, material dobrado, poros e material arrastado. O MO utilizado foi da marca OLYMPUS, modelo GX51.

\subsection{Caracterização microestrutural do filme DLC}

Para inicio das atividades de caracterização do filme DLC, foram selecionadas as camisas HD1 e HD4, uma de cada espessura de filme DLC.

As camisas foram serradas ao meio gerando duas metades $A$ e $B$. As metades do lado A serviram para gerar os corpos-de-prova para caracterização do filme DLC e a metade B para gerar os corpos-de-prova para os testes de bancada com movimento recíproco de contato a serem abordado no capítulo 4.6. 
A FIG. 47 mostra as metades "A" e "B" da camisa HD1 após ser cortada ao meio. A FIG 51 é representativa para a camisa HD4. As analises por MEV/EDS em linha (EDS Line Scan), difração de raios-X e os ensaios de nanoindentação foram realizados para caracterização microestrutural dos filmes DLC.

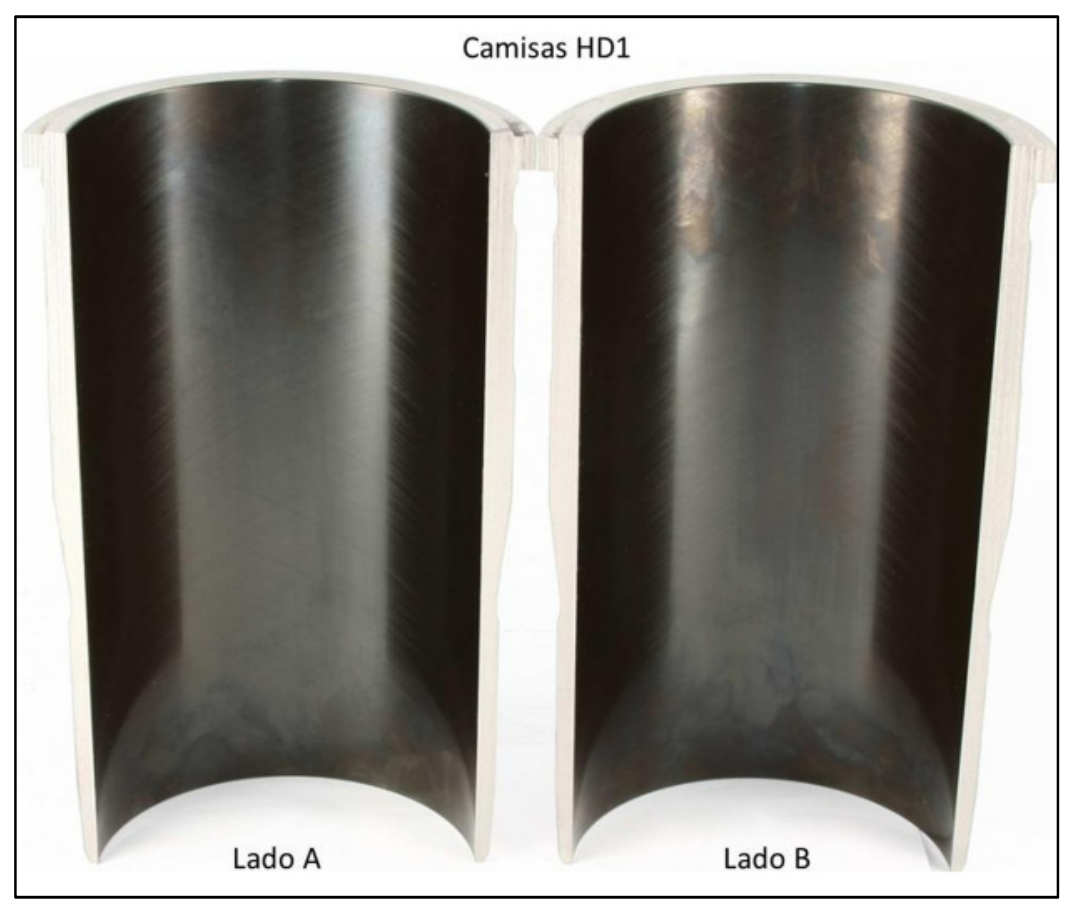

FIGURA 47 - Camisa HD1 cortada em duas metades, lados A e B.

\subsubsection{Análises MEV/EDS}

As análises de MEV/EDS foram conduzidas em corpos-de-prova que representam as seções transversais dos respectivos lados A das camisas HD1 e HD4 em três alturas diferentes em relação à face de topo conforme ilustra a FIG. 48. Os corpos-de-prova foram preparados para observação da secção transversal, tendo sidos embutidos em resina fenólica (baquelite), de cura a quente. Posteriormente, foram lixados até grana 600 em papéis abrasivos de carbeto de silício, e polidos em pastas de diamante de 6, 3 e $1 \mu \mathrm{m}$. As amostras foram recobertas com filme de papel alumínio e levadas ao MEV para análise de espessura e região de interface entre o substrato de ferro fundido e a camada intermediária de silício. Foram utilizados imagens de elétrons retro-espalhados. 


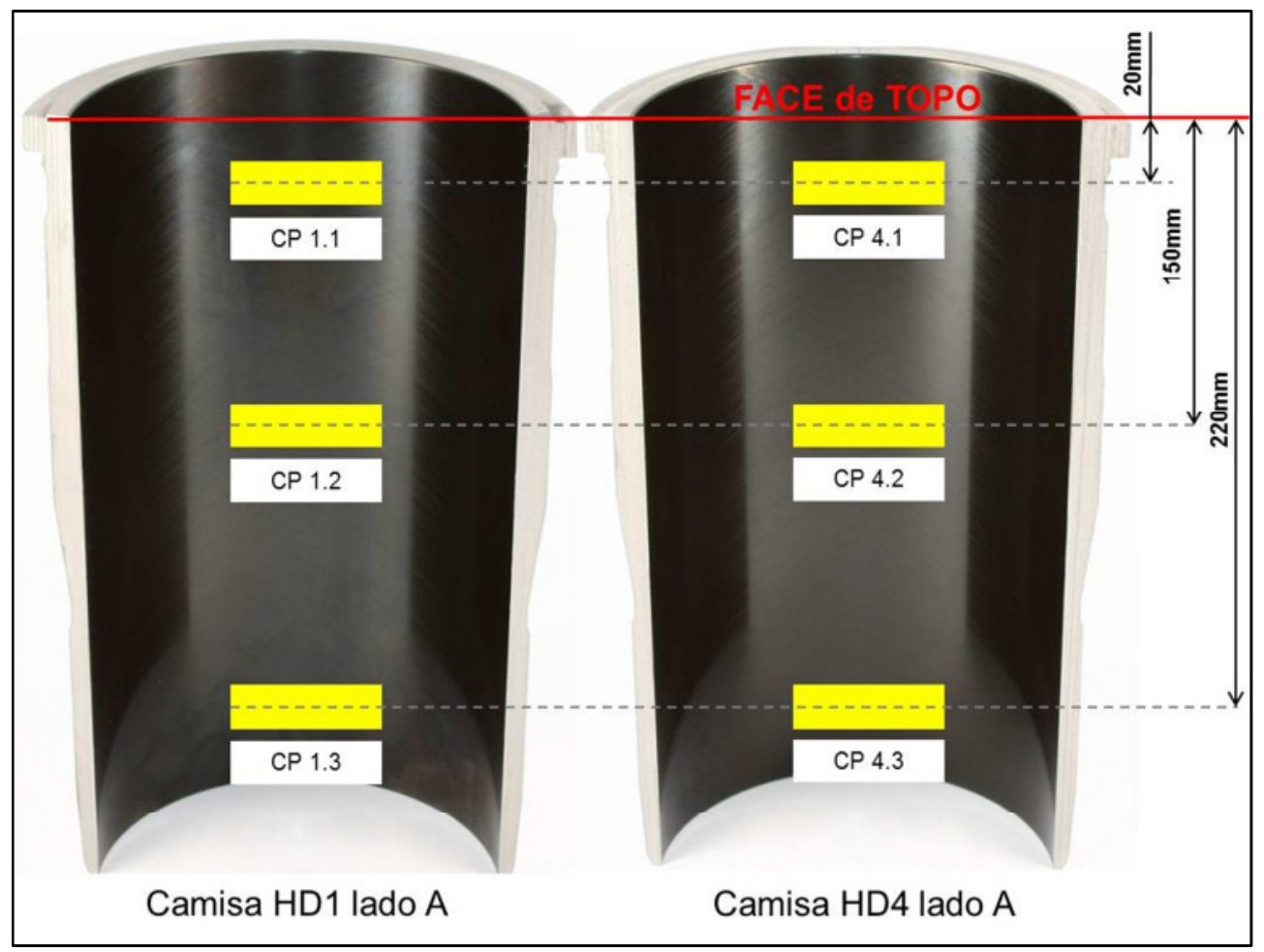

FIGURA 48 - Localização dos corpos-de-prova para análise de MEV.

A análise semiquantitativa da composição química dos filmes DLC pelas análises de MEV/EDS em linha foi realizada na seção transversal das camisas HD1, partindo do substrato de ferro fundido até a região de trabalho do filme DLC.

Os equipamentos utilizados nas análises metalográficas foi um microscópio eletrônico de varredura da marca Quanta modelo FEl 600, com analisadores por espectroscopia de energia dispersiva EDS para identificação dos constituintes e dos gradientes de composição química encontrados nos produtos de reação.

\subsubsection{Difração de raios- $X$}

As análises por difração de raios- $X$ foram feitas nas camisas com revestimento, HD1 e HD4 e na camisa camisas referência sem revestimento para identificar a presença de compostos cristalinos. Os corpos-de-prova das camisas HD1 e HD4 foram retirados de regiões próximas das analisas feitas por MEV/EDS. As análises foram feitas num difratômetro JEOL modelo JDX-11A, na configuração Bragg-Brentano com passo de $0,02^{\circ}$ e operou com tubo de raios- $X$ 
de cobalto $(\lambda=1,788965 \AA)$. A varredura adotada com o anodo de cobalto foi de $2 \theta$, com início em $20^{\circ}$ e final em $162^{\circ}$.

\subsubsection{Propriedades mecânicas}

As propriedades nanomecânicas dos filmes DLC foram investigadas através do uso da técnica de nanoindentação que utilizou corpos-de-prova extraídos dos respectivos lados "A" das camisas HD1 e HD4, em regiões coincidentes às selecionadas para análise de MEV. Os testes nanomecânicos consistem basicamente da obtenção de curvas de carga aplicada versus profundidade de penetração da ponta de diamante do nanoindentador a partir da superfície da amostra analisada.

Foi utilizado um nanoindentador modelo NanoTest-600 da MicroMaterials Ltda, com uma ponta de diamante tipo Berkovich de formato piramidal com base triangular, onde cada lado faz um ângulo de 65, $3^{\circ}$ com a normal à base. A carga foi aplicada em forma de carregamento / descarregamento sucessivos com cargas crescentes num mesmo ponto para medir a variação da dureza e do módulo de elasticidade em função da penetração. A dureza $(\mathrm{H})$ e o módulo de elasticidade (E) foram calculados utilizando-se o método descrito por OLIVER e PHARR (1992). Essas grandezas são obtidas a partir de um ciclo completo de aplicação e alívio de cargas (carregamentos e descarregamentos). A FIG. 49 mostra uma representação esquemática de uma seção em dois momentos de uma indentação e a FIG. 50 apresenta a respectiva curva de carga/descarga em função da profundidade ou deslocamento da ponta de diamante na amostra.

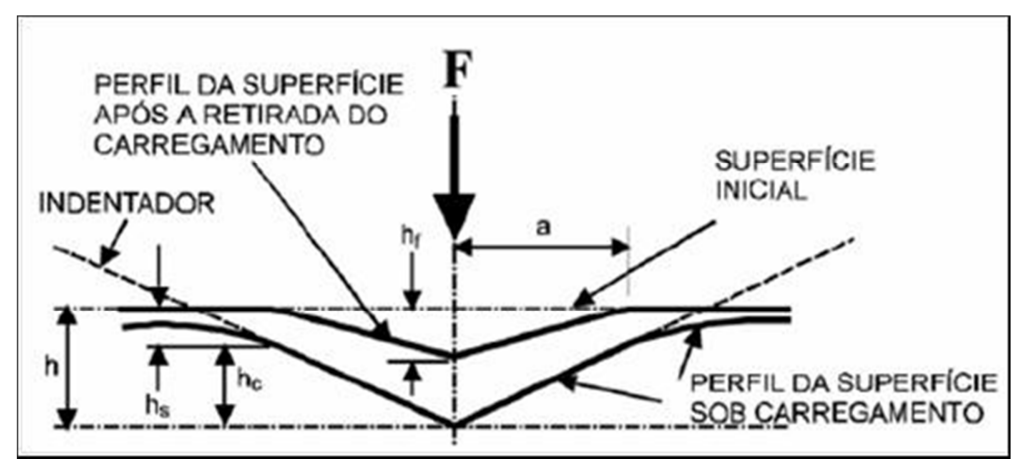

FIGURA 49 - Desenho esquemático de uma seção em dois momentos de uma indentação (OLIVER e PHARR, 1992). 


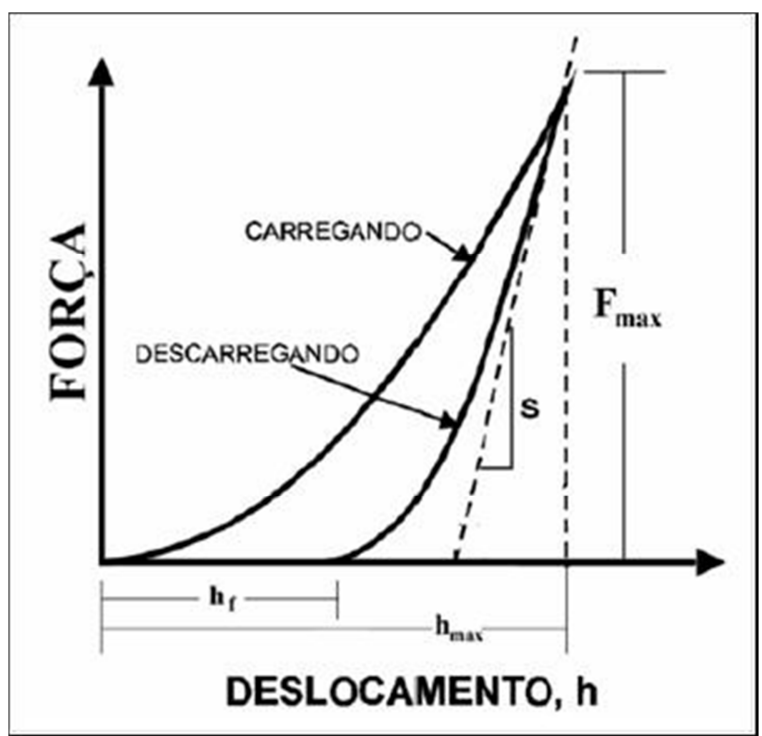

FIGURA 50 - Ciclo completo de carga e descarga de teste de nanoindentação (OLIVER e PHARR, 1992).

Em qualquer instante durante o carregamento, o deslocamento total do penetrador h é dado pela equação 10:

$$
h=h_{c}+h_{s}
$$

onde hc é a profundidade de contato e hs é o deslocamento da superfície no perímetro de contato. A carga e o deslocamento máximos são dados por Fmax. e hmax, respectivamente. Quando o penetrador está totalmente fora da amostra, a profundidade da impressão residual é dada por hf conforme ilustra a FIG. 55. A área de contato projetada, A, é função da geometria da ponta de diamante e da profundidade de contato hc. Para um penetrador Berkovich ideal, temos a equação 11 :

$$
A=24,5 h_{c}^{2}
$$

A dureza H é então obtida através da equação 12:

$$
H=\frac{F_{\max }}{A}
$$


O módulo de elasticidade $\mathrm{E}$ do material analisado pode ser extraído a partir do módulo elástico reduzido $E_{r}$, a partir da seguinte relação expressa pela equação 13:

$$
\frac{1}{E_{r}}=\frac{\left(1-\vartheta^{2}\right.}{E}+\frac{1-\vartheta_{i}^{2}}{E_{i}}
$$

onde Ei é o módulo elástico do indentador e $v_{2}$ e vi 2 são as razões de Poisson da amostra analisada e do indentador, respectivamente. O módulo de elasticidade reduzido $E_{r}$, cuja definição carrega consigo os efeitos de penetradores não-rígidos, é dado pela equação 14:

$$
E_{r}=\frac{\sqrt{\pi \cdot S}}{2 \beta \sqrt{A}}
$$

onde $\beta$ é uma constante com valor de 1,034 para o indentador Berkovich e S é a chamada rigidez, dada pela derivada da curva de descarregamento em relação à profundidade no ponto de carga máxima, conforme a equação 15:

$$
S=\frac{d F}{d h}
$$

\subsection{Propriedades tribológicas}

Os ensaios de bancada para verificar o COF utilizaram corpos-deprova das camisas HD1 e HD4 retirados dos respectivos lados B, obtidos após as camisas serem serradas ao meio. Corpos-de-prova de uma camisa referência sem revestimento também foram gerados com brunimento tipo "slide honing" semelhante aos corpos-de-prova revestidos com filme DLC. O equipamento utilizado foi um tribômetro modelo CETR UMT-2 de deslizamento recíproco que aplica um carregamento normal e constante durante um curso linear de um segmento de anel de pistão, que é gerenciado por um mecanismo servohidráulico, sendo o carregamento normal e a força de atrito, controlados por sensores do tipo "strain gages", conforme ilustra a FIG 51. O segmento de anel é fixado no suporte superior fixo sob a influência do carregamento normal e o corpo 
de prova da camisa de cilindro no suporte inferior que desenvolve o curso linear de vai-e-vem. O corpo de prova da camisa e o segmento de anel são imersos em $20 \mathrm{ml}$ de óleo tipo SAE 30 e a temperatura de $120^{\circ} \mathrm{C}$ constante durante todo o teste.

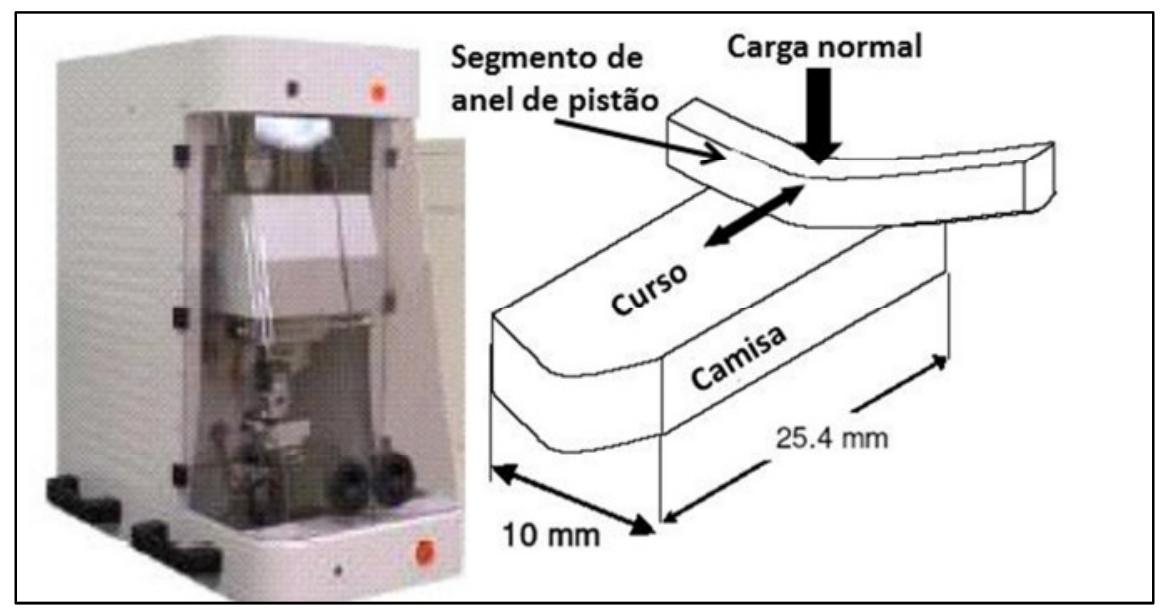

FIGURA 51 - Tribômetro modelo CETR UMT-2.

Os segmentos de anéis de pistão utilizados nos testes de bancada em aço inox nitretado com revestimento na face de contato de CrN depositado por PVD e perfil de contato abaulado assimétrico, projeto típico aplicado em motores Diesel. Os corpos-de-prova da camisa de cilindro apresentam dimensões de 25,4 x $10 \mathrm{~mm}$ (comprimento x largura) e os segmentos do anéis de pistão apresentam $30 \mathrm{~mm}$ de comprimento. A FIG. 52 ilustra o detalhe do par camisa/anel e o conjunto montado em vista superior.

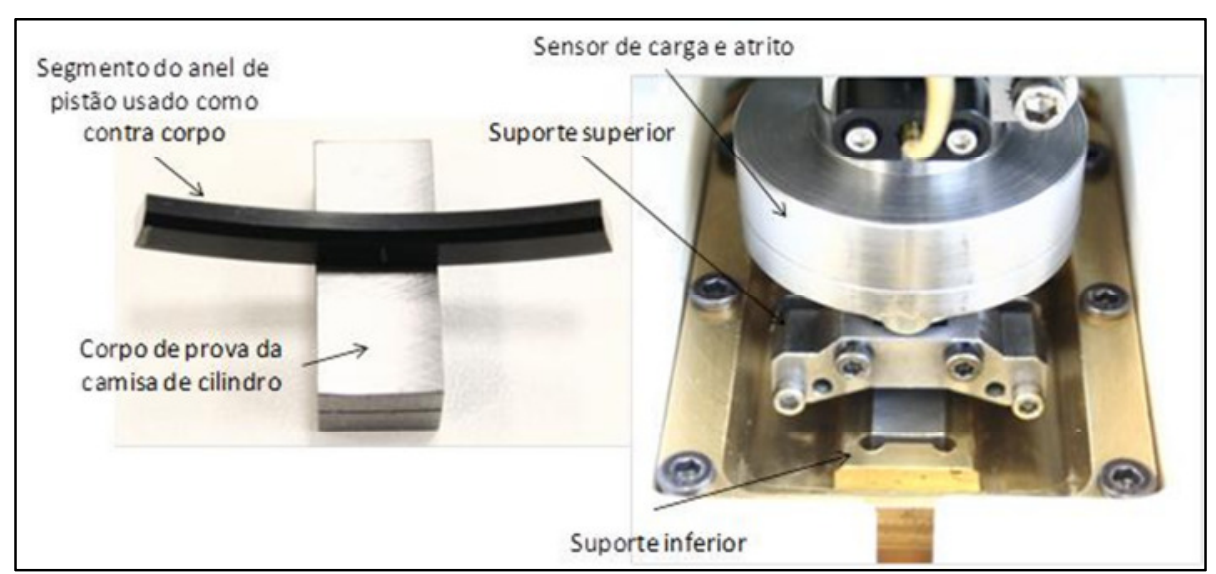

FIGURA 52 - Esquema de montagem do sistema camisa-anel de pistão no tribômetro. 
O ciclo de testes inicia-se com uma medição do COF em todas as velocidades recíprocas pré-estabelecidas fornecendo valores com índice (0h) seguido de um ciclo de amaciamento com carregamento normal constante de 360 $\mathrm{N}$ a 900 rpm durante 2 horas que promove, de forma mais acentuada, a quebra dos picos da rugosidade tanto da camisa como do anel de pistão. Ao fim do primeiro ciclo de amaciamento, o ciclo de medição do COF é repetido gerando valores com índice (2h). Como há o interesse de avaliar a influência da redução da rugosidade do par camisa/anel nos valores de COF, um segundo ciclo de amaciamento de 2 horas foi realizado seguido do ciclo de medição de COF gerando valores com índice (4h). Foram considerados cinco testes validados para cada caso estudado. Os parâmetros de teste do ciclo de amaciamento e de medição do COF se encontram na TAB. 14.

TABELA 14 - Parâmetros do teste de bancada recíproca

\begin{tabular}{|c|c|c|c|}
\hline Parâmetros de teste & Unidade & $\begin{array}{c}\text { Ciclo de } \\
\text { amaciamento }\end{array}$ & Ciclo de medição do COF \\
\hline $\begin{array}{l}\text { Curso do anel de } \\
\text { pistão }\end{array}$ & $\mathrm{mm}$ & 10 & 10 \\
\hline Óleo lubrificante & & SAE30 & SAE30 \\
\hline Temperatura do óleo & ${ }^{\circ} \mathrm{C}$ & 120 & 120 \\
\hline $\begin{array}{l}\text { Carregamento normal } \\
\text { constante }\end{array}$ & $\mathrm{N}$ & 360 & 50 e 100 \\
\hline Velocidade recíproca & rpm & 900 & $\begin{array}{c}25,50,75,100,150,250 \text { e } 375 \mathrm{p} / 50 \mathrm{~N} \\
\text { e } 50,100,150 \text { e } 200 \mathrm{p} / 100 \mathrm{~N}\end{array}$ \\
\hline
\end{tabular}

A FIG. 53 ilustra a camisa referência e a metade do lado B das camisas HD1 e HD4, posicionadas a face de topo (flange) para baixo, utilizadas na confecção dos corpos-de-prova para os testes. A FIG. 54 ilustra um anel de pistão novo com perfil de contato abaulado assimétrico revestido com CrN por PVD de onde foram extraídos os segmentos para os testes de bancada. 


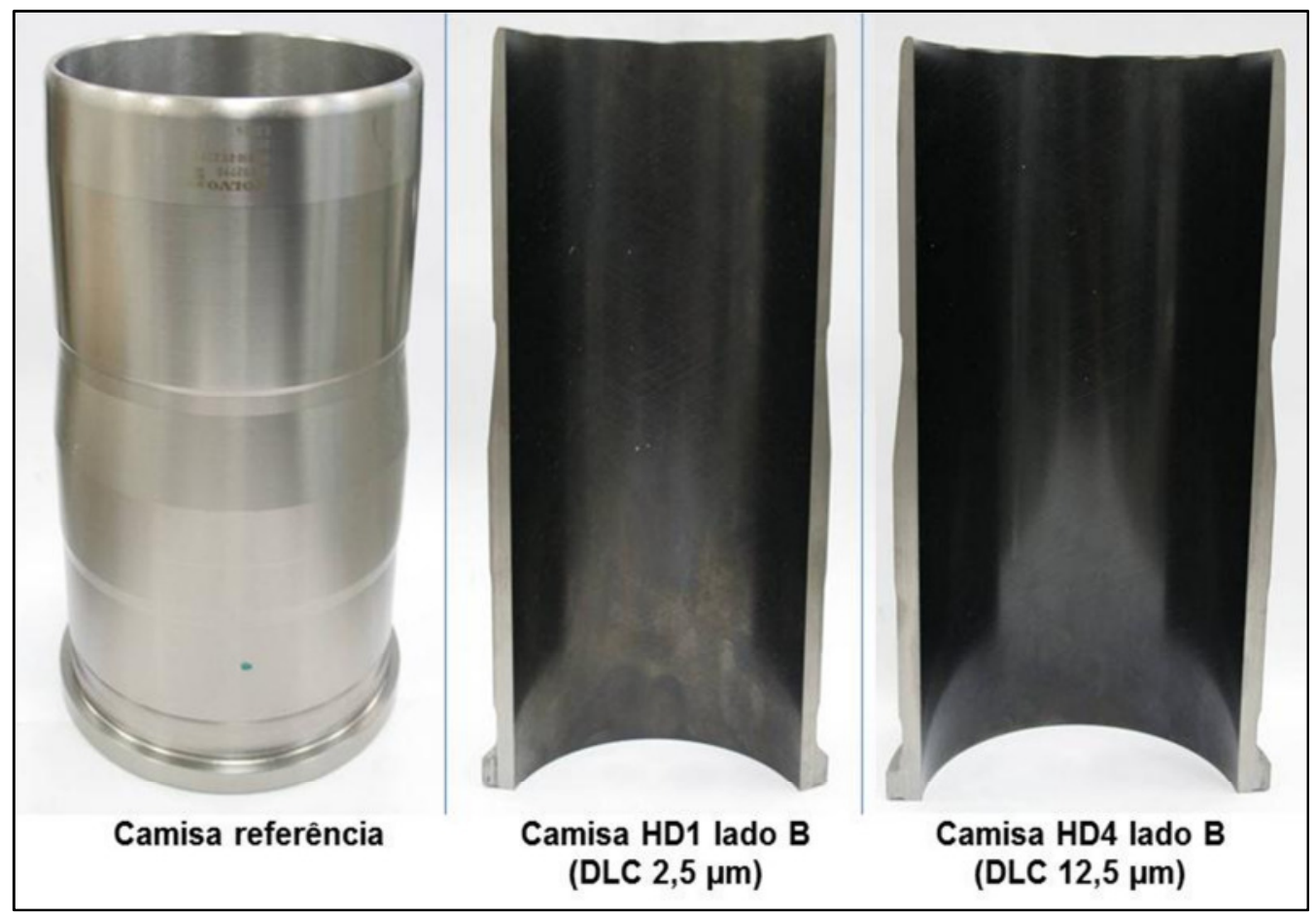

FIGURA 53 - Camisas HD utilizadas nos testes de bancada recíproco.

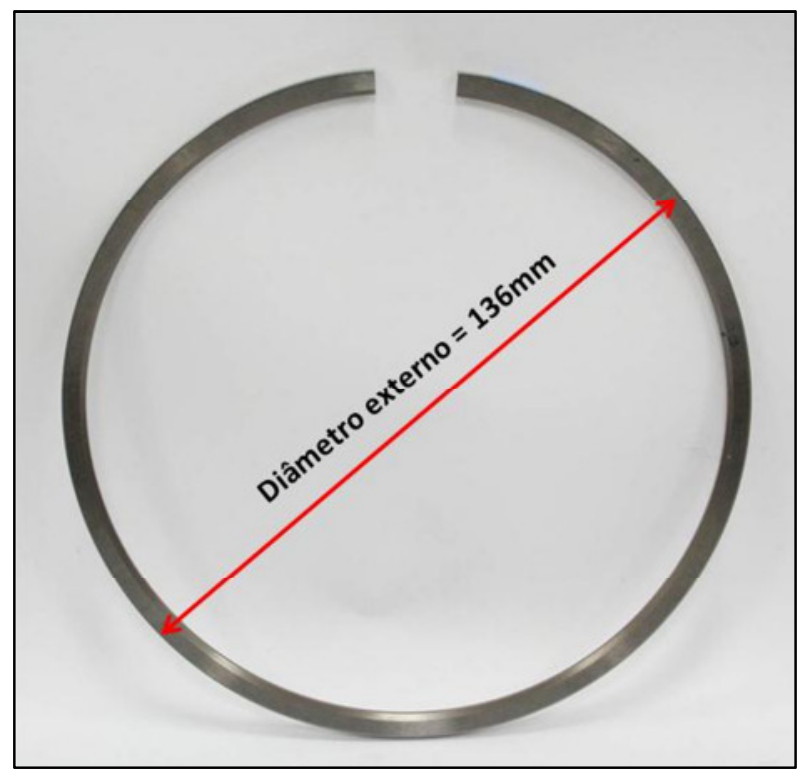

FIGURA 54 - Anel de pistão utilizado nos testes de bancada recíproco.

\subsubsection{Aquisição de dados e apresentação dos resultados do COF}

Antes de iniciar os testes de bancada, os corpos-de-prova de camisa foram submetidos a medições de retilineidade e da rugosidade superficial, assim como os segmentos dos anéis, onde se mediu o perfil de contato a fim de avaliar 
o nível de distorção e possíveis não conformidades que pudessem comprometer o contato entre o par camisa/anel durante o movimento recíproco de deslizamento.

$\mathrm{Na}$ execução do ciclo de medição do COF, após definida e registrada a sequência das condições de teste (velocidade recíproca e carregamento normal, conf. TAB. 14), o equipamento entrou em funcionamento, e durante os primeiros cinco minutos trabalhou no ciclo de COF com carregamento de $50 \mathrm{~N}$ à $25 \mathrm{rpm}$ para estabilização do sistema e logo após abriu-se o sistema de aquisição de dados para medir os valores de COF em todas as velocidades reciprocas. A medição do COF em cada velocidade reciproca durou 5 segundos. O comportamento do COF foi medido continuamente durante o deslocamento do anel num determinado sentido até o ponto de reversão e foi registrado o maior valor lido daquele sentido, se repetindo para o sentido oposto. Para cada condição de teste, foram feitas quatorze registros dos maiores valores de COF, que ocorrem sempre próximos dos respectivos pontos de reversão do anel de pistão, locais onde se espera os maiores valores de atrito devido à velocidade de deslocamento reduzida do anel, e consequentemente ha tendência de ocorrer maior contato metal-metal ou rompimento do filme de óleo. A partir das quatorze leituras realizadas, sete valores corresponderam a um sentido de deslocamento do anel de pistão e outras sete medições ao sentido oposto. Segundo TOMANIK (2008), como foi utilizado um anel de pistão assimétrico, espera-se valores de atrito diferentes de um sentido para o outro. Os valores registrados de COF recebem um sinal positivo para um sentido e negativo para o sentido oposto para facilitar os cálculos posteriores. Em cada condição de teste foi calculado um valor médio de COF a partir dos sete registros obtidos anteriormente, desta forma se obtém um valor médio de COF com sinal positivo e outro com sinal negativo em cada caso. A seguir, calcula-se para cada condição de teste um valor médio de COF em módulo para obtenção do valor final representativo, responsável por suportar um gráfico de pontos que compara os valores de COF para cada versão de camisa testada nas respectivas velocidades recíprocas.

\subsection{Testes de motor ciclo Otto à gasolina para medir a força de atrito}

Nos testes de motor ciclo Otto para medição da força de atrito, utilizouse de camisas FL referência (sem revestimento) e outra camisa FL revestida 
internamente com filme DLC de 2,5 $\mu \mathrm{m}$ de espessura, ambas com a mesma característica de brunimento. Foi utilizado um motor ciclo Otto à gasolina, desenvolvido pelo Instituto Musashi/Japão conhecido como "Floating liner engine" (FLE), baseado num dispositivo de cilindro flutuante, conforme esquema do motor ilustrado pela FIG 55, e que tem sido bastante usado em trabalhos de pesquisa para se efetuar medições de atrito em motores à combustão como os publicados por NAKAYAMA et al. (2002), SATO et al. (2004), TOMANIK e FERRARESE (2006).

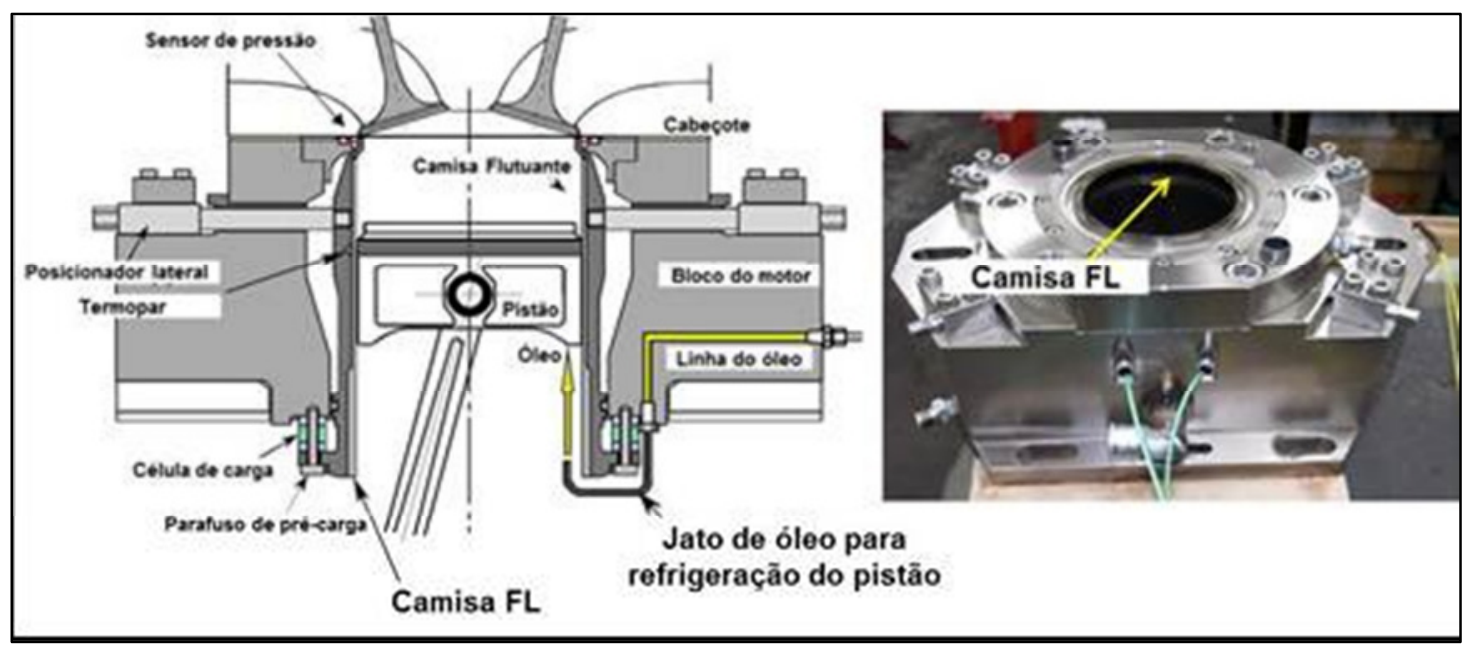

FIGURA 55 - Esquema do motor ciclo Otto à gasolina (SATO et al., 2004).

$O$ atrito pode ser medido em condições de operação diferenciadas, de rotação e IMEP (NAKAYAMA et al., 2002).

O motor foi acoplado a um dinamômetro de correntes parasitas para garantir as condições de operação pré-estabelecidas durante o teste.

Basicamente, o FLE consiste em um motor monocilíndrico modificado, onde a camisa FL é instalada num dispositivo com certo grau de liberdade vertical, porém controlado por células de carga que têm a função de medir a força vertical que o pistão e os anéis de pistão imprimem na camisa FL durante o movimento de subida e descida do conjunto. As principais características do motor estão resumidas na TAB. 15. 
TABELA 15 - Dados do motor ciclo Otto à gasolina (FLE)

\begin{tabular}{ccc}
\hline Características do motor & Unidade & Especificações \\
\hline Deslocamento volumétrico & $\mathrm{cm}^{3}$ & 646 \\
Diâmetro do cilindro x curso & $\mathrm{mm}$ & $96,0 \times 89,2$ \\
do pistão & & $10: 1$ \\
Taxa de compressão & & $1500 / 630$ \\
Condições de operação & $\mathrm{rpm} / \mathrm{kPa}$ & $2000 / 630$ \\
(velocidade e IMEP) & & $2000 / 730$ \\
& & $2500 / 630$ \\
Tipo do óleo lubrificante & & SAE 5W-30 SL/GF classe 3 \\
Temperatura do cilindro & ${ }^{\circ} \mathrm{C}$ & 100 \\
Temperatura do óleo & ${ }^{\circ} \mathrm{C}$ & 85 \\
lubrificante & &
\end{tabular}

Os sinais medidos nas células de carga são filtrados e codificados em valor de força $(N)$, que posteriormente são apresentados em gráficos em função do ângulo do virabrequim do motor, semelhantes ao apresentado pela FIG. 56. O FMEP é calculado pelo gráfico da força de atrito em função do ângulo do virabrequim obtida ao final do teste para cada regime de operação definido. $O$ FMEP leva em consideração o valor da força de atrito e o deslocamento realizado pelo pistão, sendo mais significativo em regiões do meio curso entre as regiões de reversão do pistão superior e inferior (HEYWOOD, 1998). Para cada condição de operação do motor em teste é necessário um tempo para que o motor se estabilize. A seguir, inicia-se a aquisição de dados da força de atrito. Durante a aquisição de dados três repetições de medição são geradas para o cálculo final do FMEP médio. Os valores obtidos em cada repetição são considerados válidos desde que apresentem uma diferença inferior a $4 \%$. Foram conduzidos dois testes em sequência, o primeiro utilizando camisa FL referência e o segundo com camisa FL revestida com filme DLC. Foram realizadas paradas parciais a cada 5 horas para inspeção das camisas FL, onde a rugosidade da superfície interna foi medida, conforme os parâmetros da série Rk, próximo da região de reversão superior dos anéis de pistão, a $10 \mathrm{~mm}$ do topo, e próximo da metade do curso do pistão e a $45 \mathrm{~mm}$ do topo. Foi feita também a substituição do anel o'ring, que faz a vedação da câmara de combustão. Um ciclo de amaciamento de $15 \mathrm{~h}$ foi executado para cada camisa FL antes de se iniciar as medições da força de atrito, 
com o objetivo de promover a quebra das superfícies em contato, e obter um melhor assentamento dos componentes, camisa $F L$ e anéis de pistão. Considerando um período mínimo de 1 hora para estabilização do motor em cada condição de operação, foi consumido um total $5 \mathrm{~h}$ para concluir as quatro condições de operação pré-definidas. Desta forma, para se conseguir três testes válidos, cada versão de motor acumulou um total de $30 \mathrm{~h}$ de rodagem.

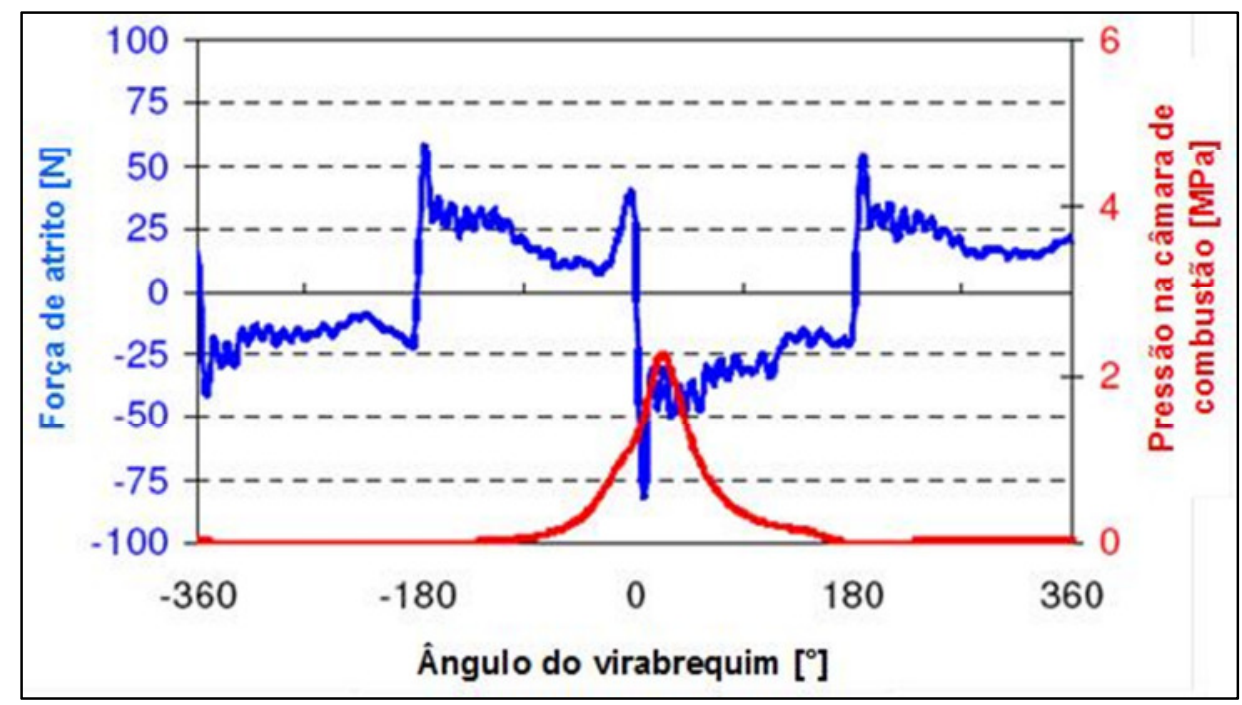

FIGURA 56 - Resultados da medição da força de atrito no motor FLE, 1500 rpm, BMEP= 380 kPa (TOMANIK e FERRARESE, 2006).

\subsection{Teste de motor ciclo Diesel}

O motor ciclo Diesel utilizado nas etapas de desenvolvimento do conceito e da validação do conceito é um motor com injeção direta de combustível, turbo-comprimido, com pós-resfriamento, 6 cilindros em linha, potência de 131 kW a 1580 rpm, torque de 2850 Nm a 1200 rpm, curso do pistão de $158 \mathrm{~mm}$, deslocamento volumétrico de 12,8 L liberado para atender aos níveis de emissões EURO 3 (PROCONVE 5), acoplado num dinamômetro de correntes parasitas equipado com sensor de carga AVL W700, com precisão de desvio máximo de 1,5\%. O consumo específico de combustível foi controlado pelo equipamento AVL 733 S com precisão de desvio máximo de $0,1 \%$.

$\mathrm{Na}$ fase do desenvolvimento do conceito, o primeiro teste foi conduzido seguindo um ciclo padrão para avaliar a durabilidade dos filmes DLC, optando-se por uma configuração de montagem das camisas HD2 e HD6, juntamente com 
outras camisas de referência, conforme descrito na TAB. 16. O motor rodou as 10 h primeiras horas seguindo um ciclo de amaciamento padrão e após completar este período de rodagem, foi desligado para uma inspeção parcial das camisas HD. Em seguida, o motor foi fechado para completar $500 \mathrm{~h}$ de rodagem de acordo com um ciclo de durabilidade padrão. As TAB. 17 e 18 descrevem os detalhes dos passos adotados em cada ciclo padrão de teste de motor ciclo Diesel.

TABELA 16 - Configuração de montagem do motor ciclo Diesel para teste de $500 \mathrm{~h}$ - Fase de desenvolvimento do conceito.

\begin{tabular}{ccccccc}
\hline $\begin{array}{c}\text { Posição de } \\
\text { montagem } \\
\text { no motor }\end{array}$ & Pos.\#1 & Pos.\#2 & Pos. \#3 & Pos. \#4 & Pos.\#5 & Pos. \#6 \\
\hline $\begin{array}{c}\text { Tipo de } \\
\text { camisa }\end{array}$ & $\begin{array}{c}\text { Camisa } \\
\text { de } \\
\text { referência }\end{array}$ & $\begin{array}{c}\text { Camisa } \\
\text { de } \\
\text { referência }\end{array}$ & $\begin{array}{c}\text { Camisa } \\
\text { de } \\
\text { referência }\end{array}$ & $\begin{array}{c}\text { Camisa } \\
\text { de } \\
\text { referência }\end{array}$ & $\begin{array}{c}\text { Camisa } \\
\text { HD2 }\end{array}$ & $\begin{array}{c}\text { Camisa } \\
\text { HD6 }\end{array}$ \\
\hline
\end{tabular}

TABELA 17 - Ciclo de amaciamento padrão do motor ciclo Diesel.

\begin{tabular}{cccc}
\hline Passo & Velocidade $\left[\mathrm{min}^{-1}\right]$ & Torque $[\mathrm{Nm}]$ & Duração do passo [s] \\
\hline 1 & 1200 & 517 & 600 \\
2 & 1200 & 1030 & 300 \\
3 & 1800 & 1552 & 300 \\
4 & 1800 & 2850 & 600 \\
5 & 1800 & 2850 & 7.200 \\
6 & 1800 & 2850 & 27.000 \\
\hline
\end{tabular}

Tempo total de amaciamento: $10 \mathrm{~h}$

Tolerância aceita nos parâmetros medidos: $\pm 2 \%$ 
TABELA 18 - Ciclo de durabilidade padrão do motor ciclo Diesel.

\begin{tabular}{cccc}
\hline Passo & Velocidade $\left[\mathrm{min}^{-1}\right]$ & Torque $[\mathrm{Nm}]$ & Duração do passo [s] \\
\hline 1 & 600 & 0 & 240 \\
2 & 1800 & 2850 & 200 \\
3 & 2100 & 0 & 180 \\
4 & 1667 & 2850 & 428 \\
5 & 1533 & 2850 & 428 \\
6 & 1400 & 2850 & 848 \\
7 & 1267 & 2850 & 848 \\
8 & 1200 & 2850 & 428 \\
9 & 1133 & 2850 & 360 \\
\hline
\end{tabular}

Tempo total de um ciclo de durabilidade: 1 h06 min

Tolerância aceita nos parâmetros medidos: $\pm 2 \%$

$\mathrm{Na}$ fase de validação do conceito foi utilizado o mesmo modelo do motor Diesel utilizado na fase anterior, assim como os ciclos padrões de amaciamento e de durabilidade, entretanto foram rodados dois testes em sequência onde se buscou montar jogos de camisas HD diferentes, sendo neste caso o motor \#1 e motor \#2. Ambos os motores completaram um total de $125 \mathrm{~h}$ de rodagem no banco de provas. O motor \#1 rodou com seis camisas referência e o motor \#2 com seis camisas revestidas com filme DLC com espessura nominal de 2,5 $\mu \mathrm{m}$. Assim que os motores completaram as $125 \mathrm{~h}$ de rodagem, uma curva de desempenho foi levantada logo na sequencia para cada um deles. A curva de desempenho é uma forma de avaliar o desempenho do motor após certo tempo de rodagem e, sendo assim, considerou-se valores de velocidade de 1000 até 2000 rpm com carga total e aceleração máxima. Por meio deste ensaio obteve-se um mapeamento do motor com dados de potência, torque e BSFC para cada velocidade. Foram feitas três curvas de desempenho para cada motor onde se calculou uma média dos valores medidos para obtenção de um gráfico de potência, torque e BSFC em função da velocidade do motor. Neste gráfico foram sobrepostos os valores médios calculados dos motores testados, motor \#1 e motor \#2.

Ao final dos testes, ambos os motores foram desmontados para verificação do nível de desgaste nas camisas $H D$, na região TDC, e também nas faces de contato dos anéis de pistão de primeiro canalete. A medições nas 
camisas foram feitas pelo método convencional de traçagem de perfil 2D em quatro posições angulares tomando como referência a montagem no motor. A avaliação de desgaste nos anéis de pistão do primeiro canalete foi realizada por intermédio da sobreposição dos perfis antes e após o teste de motor. Desta forma foi possível comparar as diferenças e consequentemente determinar os níveis de desgaste.

\section{9 - Pacote de anéis de pistão}

Nos testes realizados no motor FLE, foi utilizado o pacote de anéis mostrado na TAB. 19.

TABELA 19 - Especificação dos anéis para o motor ciclo Otto à gasolina (FLE).

\begin{tabular}{cr}
\hline Posição de montagem do anel & Descrição \\
\hline $1^{\text {a } \text { canalete }}$ & Anel em aço inox nitretado com perfil de contato \\
& abaulado simétrico \\
$2^{2}$ canalete & Anel raspador em ferro fundido cinzento perlítico \\
& Anel 3 peças com segmento em aço carbono \\
$3^{3}$ canalete & martensítico revestido com cromo na face de \\
& contato $(\sim 50 \mu \mathrm{m}$ de espessura $)$ \\
\hline
\end{tabular}

Nos testes realizados no motor Diesel, utilizou-se o pacote de anéis mostrado na TAB. 20.

TABELA 20 - Jogos de anéis utilizados no motor ciclo Diesel.

\begin{tabular}{|c|c|}
\hline Posição de montagem do anel & Descrição \\
\hline $1^{\text {a }}$ canalete & $\begin{array}{l}\text { Anel em aço inox nitretado revestido com CrN, } \\
\text { depositado por PVD (espessura } \sim 20 \mu \mathrm{m} \text { ), e perfil } \\
\text { de contato abaulado assimétrico }\end{array}$ \\
\hline $2^{a}$ canalete & $\begin{array}{l}\text { Anel raspador em ferro fundido cinzento perlítico } \\
\text { revestido com cromo ( 100 } \mu \mathrm{m} \text { de espessura) }\end{array}$ \\
\hline $3^{\text {a }}$ canalete & $\begin{array}{c}\text { Anel } 2 \text { peças com segmento em aço inox } \\
\text { nitretado }\end{array}$ \\
\hline
\end{tabular}




\subsection{0 - Espectroscopia de espalhamento Raman}

A espectroscopia de espalhamento Raman é baseada no efeito Raman, que corresponde às radiações espalhadas a partir de uma amostra com frequência ligeiramente diferente da radiação incidente. O espalhamento Raman pode ser explicado como sendo uma colisão inelástica entre um fóton incidente e uma molécula em um determinado estado inicial de energia.

Para investigar filmes finos com estruturas cristalinas ou amorfas, recomenda-se utilizar métodos não destrutivos. Neste caso a técnica Raman foi fundamental para avaliar a razão de ligações $\mathrm{sp}^{2} / \mathrm{sp}^{3}$ presentes no filme DLC em diversas regiões das camisas HD novas e após $125 \mathrm{~h}$ de rodagem no motor ciclo Diesel. Os espectros Raman obtidos no filme DLC depositado na camisa HD nova serviram para gerar espectros de referência. As analises feitas na camisa HD após teste de motor teve como foco principal objetivo comparar o espectro medido com os padrões de referência assim como o comportamento da razão entre as ligações $\mathrm{sp}^{2} / \mathrm{sp}^{3}$ nas regiões que foram submetidas à alta temperatura de combustão e ao desgaste mais severo promovido pelo contato dos anéis de pistão. Os espectros Raman foram obtidos usando um equipamento Micro-Raman modelo System 2000 da marca Renishaw. Os fótons incidentes são provenientes de um laser de excitação de argônio com potência de $8 \mathrm{~mW}$ e comprimento de onda $\lambda=514.5 \mathrm{~nm}$. A radiação incidente é capturada por um microscópio óptico da marca Olympus com objetiva de 50 vezes. Os fótons emitidos pela amostra são coletados pelo próprio sistema de lentes do microscópio, que no caso inverso age como telescópio, e enviados para um monocromador de rede que permite a separação espectral das frequências. A aquisição dos dados pelo espalhamento Raman se deu numa varredura no intervalo de $950-1830 \mathrm{~cm}^{-1}$. A FIG. 57 mostra as regiões de retirada dos corpos-de-prova, denominados como $\mathrm{CP}$, da camisa HD nova e da camisa HD que completou $125 \mathrm{~h}$ de rodagem em teste de motor. Para facilitar a interpretação dos resultados, cada CP foi enumerado de forma sequencial. 


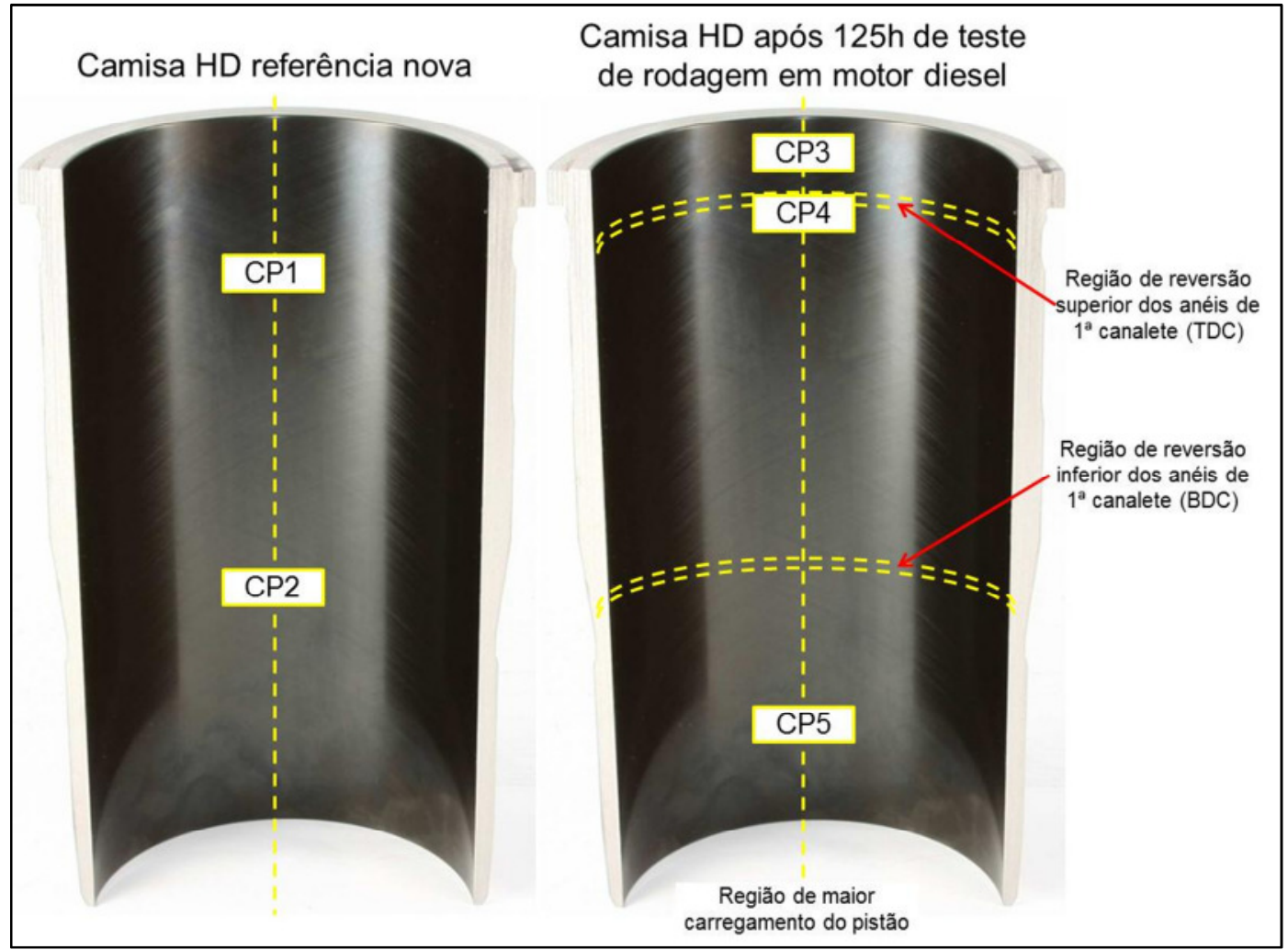

FIGURA 57 - Esquema de retirada de corpos-de-prova para análise Raman. 


\section{RESULTADOS E DISCUSSÃO}

\subsection{Primeira fase - Desenvolvimento do conceito}

\subsubsection{Verificação da integridade dimensional das camisas com filme DLC}

Os resultados da medição do diâmetro interno das camisas HD nas várias alturas são apresentados na TAB. 21. Através da diferença do diâmetro medido antes e após a deposição do filme DLC se obtém por diferença a espessura do filme depositado. Observa-se que os valores de espessura calculados para as camisas HD1 e HD2 estão próximos do valor nominal especificado de 2,50 $\mu \mathrm{m}$, com valor médio de 2,12 $\mu \mathrm{m}$ e variação máxima de 1,00 $\mu \mathrm{m}$. As espessuras calculadas para as camisas HD4 e HD6 também ficaram próximos do valor nominal especificado de 12,50 $\mu \mathrm{m}$, com valor médio de 12,62 $\mu \mathrm{m}$ e variação máxima de $1,50 \mu \mathrm{m}$. Outra observação é que os valores medidos do diâmetro interno após a deposição do filme DLC não ultrapassaram os limites especificados pelo projeto da camisa HD, que é de 130,975 a 131,020 mm e, sendo assim, não houve restrição ao uso em testes de motor.

TABELA 21 - Diâmetro interno das camisas HD

\begin{tabular}{|c|c|c|c|c|c|c|}
\hline $\begin{array}{c}\text { Identificação da } \\
\text { camisa HD }\end{array}$ & $\begin{array}{l}\text { Altura em } \\
\text { relação ao topo }\end{array}$ & $\begin{array}{c}\text { Sentido de } \\
\text { medição }\end{array}$ & Antes & Depois & $\begin{array}{l}\text { Espessura do } \\
\text { filme DLC } \\
\text { calculado [mm] }\end{array}$ & $\begin{array}{l}\text { Média } \\
{[\mathrm{mm}]}\end{array}$ \\
\hline \multirow{4}{*}{ HD1 } & $30 \mathrm{~mm}$ & \multirow{2}{*}{$0^{\circ}-180^{\circ}$} & 131,009 & 131,004 & 2,50 & \multirow{8}{*}{2,12} \\
\hline & $90 \mathrm{~mm}$ & & 131,010 & 131,005 & 2,50 & \\
\hline & $30 \mathrm{~mm}$ & \multirow{2}{*}{$90^{\circ}-270^{\circ}$} & 131,011 & 131,006 & 2,50 & \\
\hline & $90 \mathrm{~mm}$ & & 131,013 & 131,009 & 2,00 & \\
\hline \multirow{4}{*}{ HD2 } & $30 \mathrm{~mm}$ & \multirow{2}{*}{$0^{\circ}-180^{\circ}$} & 131,010 & 131,007 & 1,50 & \\
\hline & $90 \mathrm{~mm}$ & & 131,011 & 131,008 & 1,50 & \\
\hline & $30 \mathrm{~mm}$ & \multirow{2}{*}{$90^{\circ}-270^{\circ}$} & 131,006 & 131,001 & 2,50 & \\
\hline & $90 \mathrm{~mm}$ & & 131,010 & 131,006 & 2,00 & \\
\hline \multirow{4}{*}{ HD4 } & $30 \mathrm{~mm}$ & \multirow{2}{*}{$0^{\circ}-180^{\circ}$} & 131,010 & 130,986 & 12,00 & \multirow{8}{*}{12,62} \\
\hline & $90 \mathrm{~mm}$ & & 131,012 & 130,987 & 12,50 & \\
\hline & $30 \mathrm{~mm}$ & \multirow{2}{*}{$90^{\circ}-270^{\circ}$} & 131,013 & 130,987 & 13,00 & \\
\hline & $90 \mathrm{~mm}$ & & 131,013 & 130,986 & 13,50 & \\
\hline \multirow{4}{*}{ HD6 } & $30 \mathrm{~mm}$ & \multirow{2}{*}{$0^{\circ}-180^{\circ}$} & 131,009 & 130,985 & 12,00 & \\
\hline & $90 \mathrm{~mm}$ & & 131,016 & 130,991 & 12,50 & \\
\hline & $30 \mathrm{~mm}$ & \multirow{2}{*}{$90^{\circ}-270^{\circ}$} & 131,008 & 130,983 & 12,50 & \\
\hline & $90 \mathrm{~mm}$ & & 131,014 & 130,988 & 13,00 & \\
\hline
\end{tabular}

A análise da deformação diametral de $2^{\mathrm{a}}$ ordem, representada pela medição da circularidade do diâmetro interno, é apresentada nas FIG. 58, 59, 60 
e 61 por gráficos de barras horizontais que ilustram o comportamento deste erro de forma as doze alturas das camisas HD definidas no item 4.4. Os valores indicados pelas barras de cor verde claro se referem aos valores medidos antes do processo de deposição do filme DLC, as barras de cor violeta representam os valores de circularidade após a deposição do filme DLC e as barras de azul claro mostram a diferença observada, sendo valores positivos, uma indicação de que a deformação aumentou. As camisas HD possuem especificações limites de projeto para valores máximos de circularidade ao longo do comprimento, que são representados pelas linhas verticais em vermelho nos gráficos, sendo $10 \mu \mathrm{m}$ a partir da face de topo até $200 \mathrm{~mm}$ e de $15 \mu \mathrm{m}$ a partir de $200 \mathrm{~mm}$ até o fim do comprimento.

Observa-se na camisa HD1, antes de receber o filme DLC, a tendência de aumento dos valores de circularidade no sentido da região inferior. Os valores medidos após a deposição do filme DLC mostram a mesma tendência, entretanto, a diferença observada tende a ser maior na região inferior, local onde se havia observado tendência de maiores valores antes do processo de deposição. Notase que nas regiões a partir de $150 \mathrm{~mm}$, os valores de circularidade ficaram acima dos limites especificados pelo projeto.

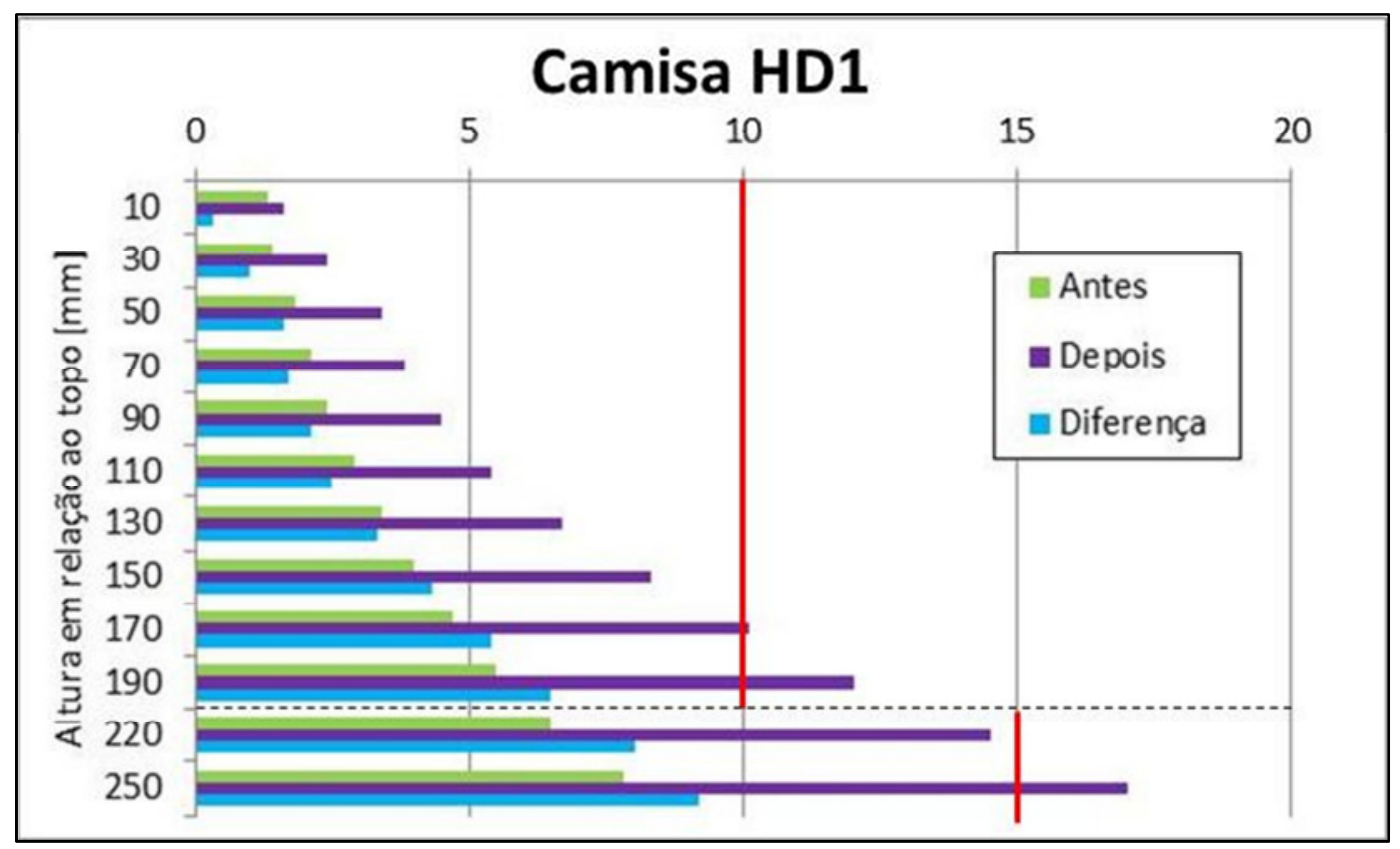

FIGURA 58 - Resultados de medição da circularidade do diâmetro interno para camisa HD1. 
A tendência de aumento da deformação diametral na região inferior pode ser explicada pelo fato de que nesta região a camisa HD tem uma espessura de parede menor e, portanto, mais vulnerável a deformações, principalmente se sofrer com batidas durante o transporte, posicionamento incorreto durante a estocagem ou em função de um processo de manuseio indevido.

A camisa HD2 apresentou um comportamento diferente da camisa HD1 antes da deposição do filme DLC. Os maiores valores foram observados nas extremidades superior e inferior. Após a deposição do filme DLC, os valores acompanharam a tendência anterior. Não foi observado valores acima dos limites especificados pelo projeto em nenhuma das alturas medidas. Similar ao que ocorreu com a camisa HD1, não se observou nenhuma diferença com sinal negativo, o que indica que a deformação diametral aumentou após o processo de deposição do filme DLC.

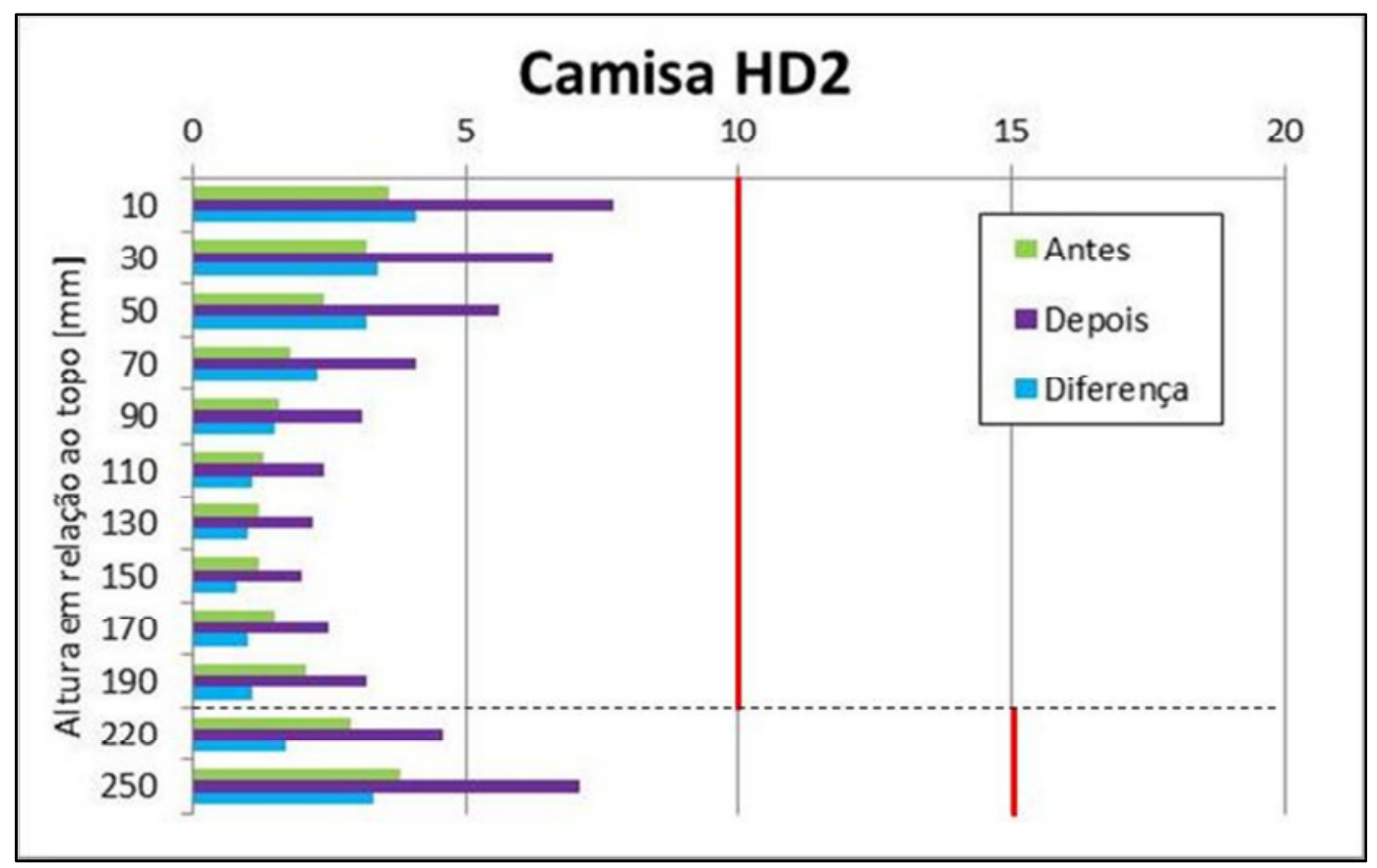

FIGURA 59 - Resultados de medição da circularidade do diâmetro interno para camisa HD2.

A camisa HD4 apresentou valores de circularidade com menor variação ao longo do seu comprimento antes da deposição do filme DLC, o que influenciou nos valores medidos após a deposição do filme DLC. Verificou-se também nesta 
camisa que os valores positivos de diferença em todas as alturas medidas, reforçando aumento da circularidade após o processo de deposição, porém, todos os valores ficaram abaixo dos limites especificados do projeto e variação reduzida ao longo do comprimento.

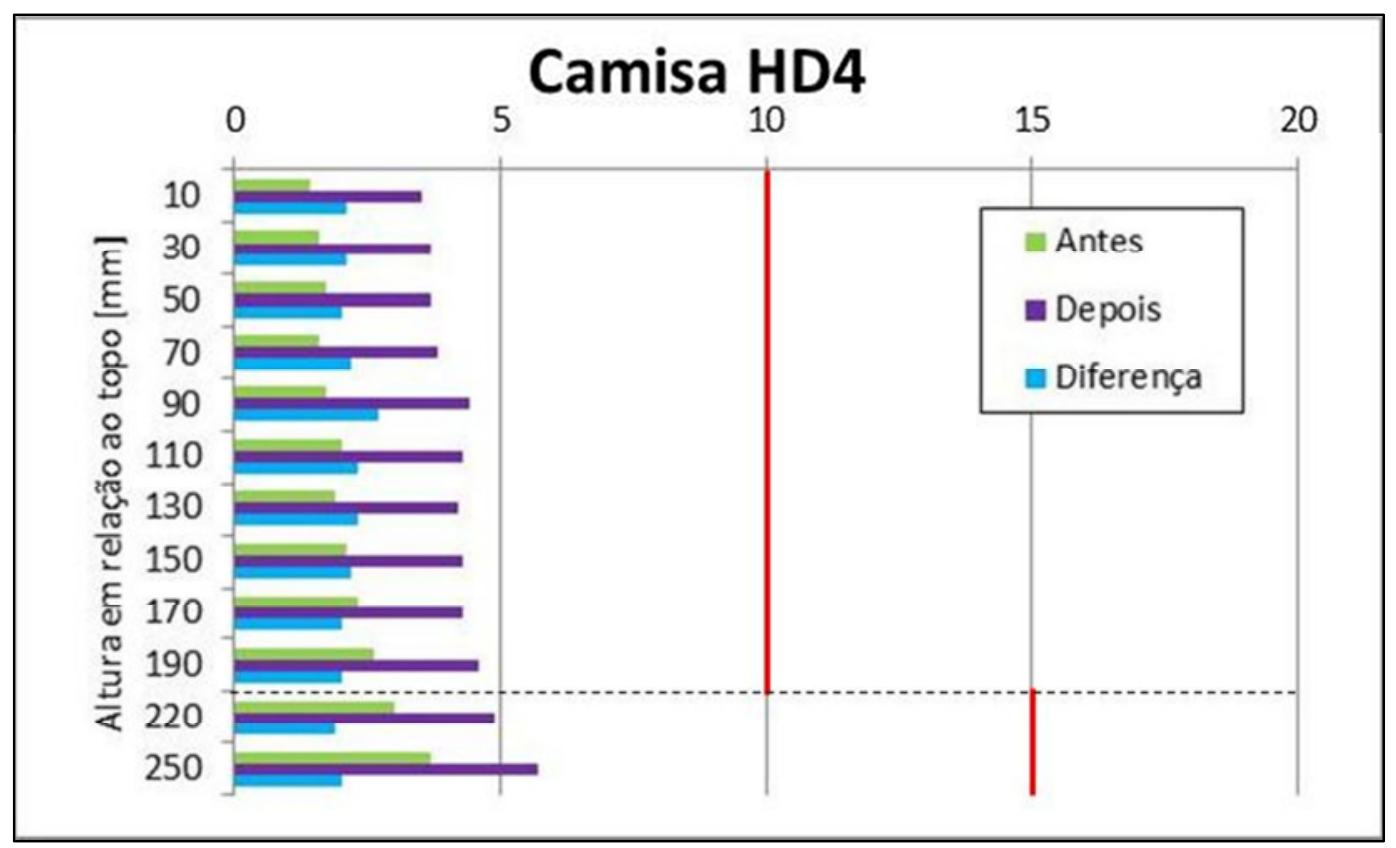

FIGURA 60 - Resultados de medição da circularidade do diâmetro interno para camisa HD4.

A camisa HD6 apresentou comportamento semelhante ao observado na camisa HD1, registrando aumento da deformação diametral no sentido da região inferior, porém, respeitando os limites máximos de projeto. Verificou-se, somente na primeira altura de medição, um valore negativo da diferença e que, portanto, indica uma redução da deformação diametral localizada.

Em todas as camisas foi possível verificar que a circularidade aumenta por conta do processo de deposição do filme DLC, o que torna esta característica dimensional, fundamental para o controle de qualidade do produto.

Todos os valores compilados nas análises de circularidade estão disponíveis para verificação no APÊNDICE A. 


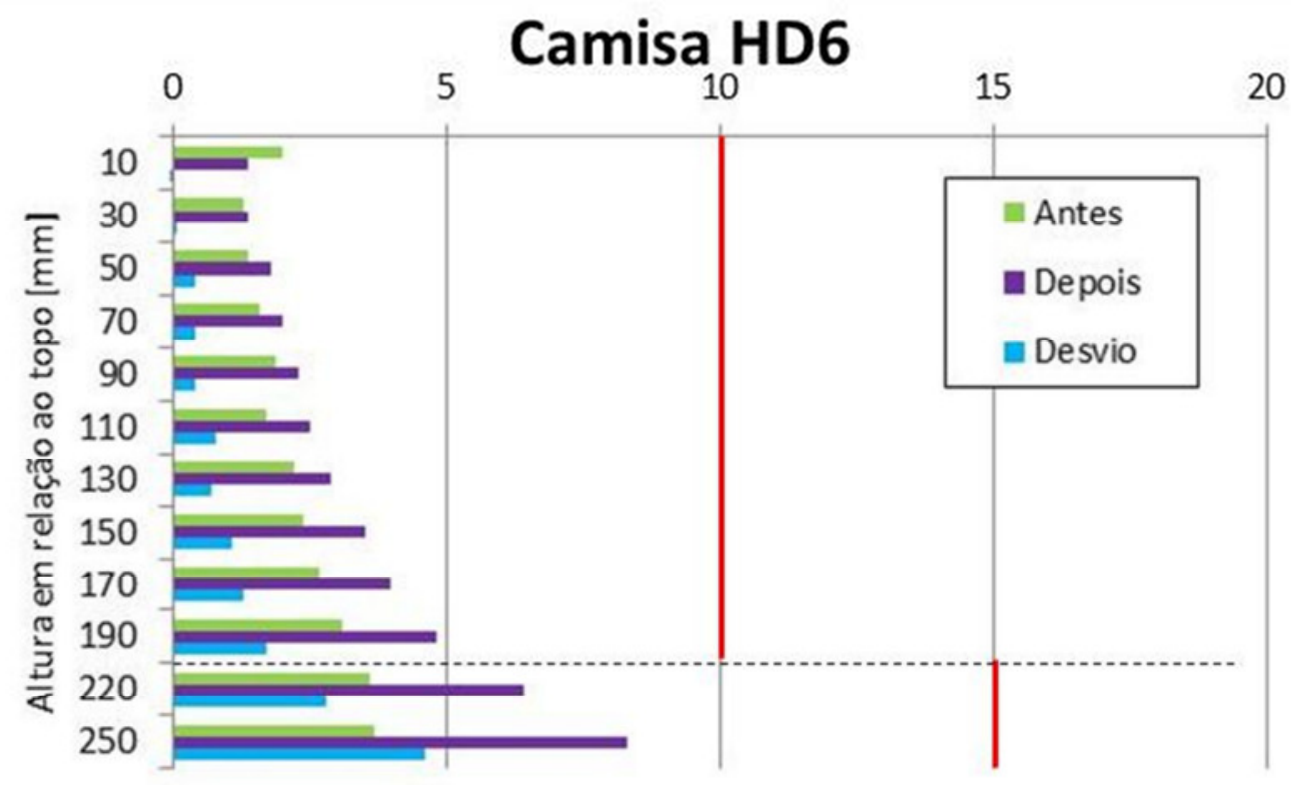

FIGURA 61 - Resultados de medição da circularidade do diâmetro interno para camisa HD4.

Perfis de traçagem representativos de todas as camisas HD, obtidas pelo equipamento de erro de forma, são apresentadas nas FIG. 62 e 63 referente a camisa HD1 nas alturas de 50 e $190 \mathrm{~mm}$.

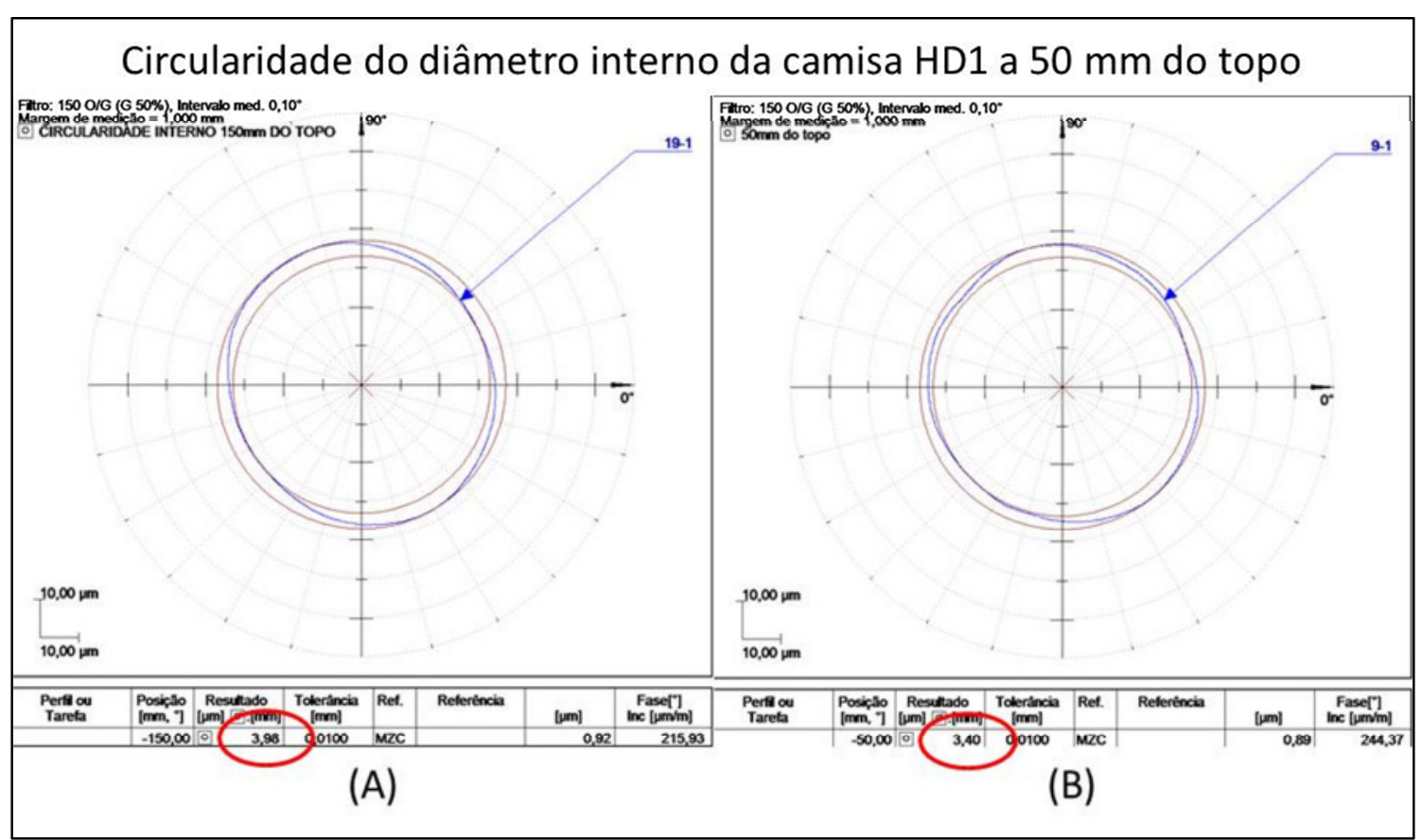

FIGURA 62 - Circularidade do diâmetro interno, camisa HD1. Altura 50 mm, (A) antes e (B) após a deposição do filme DLC. 


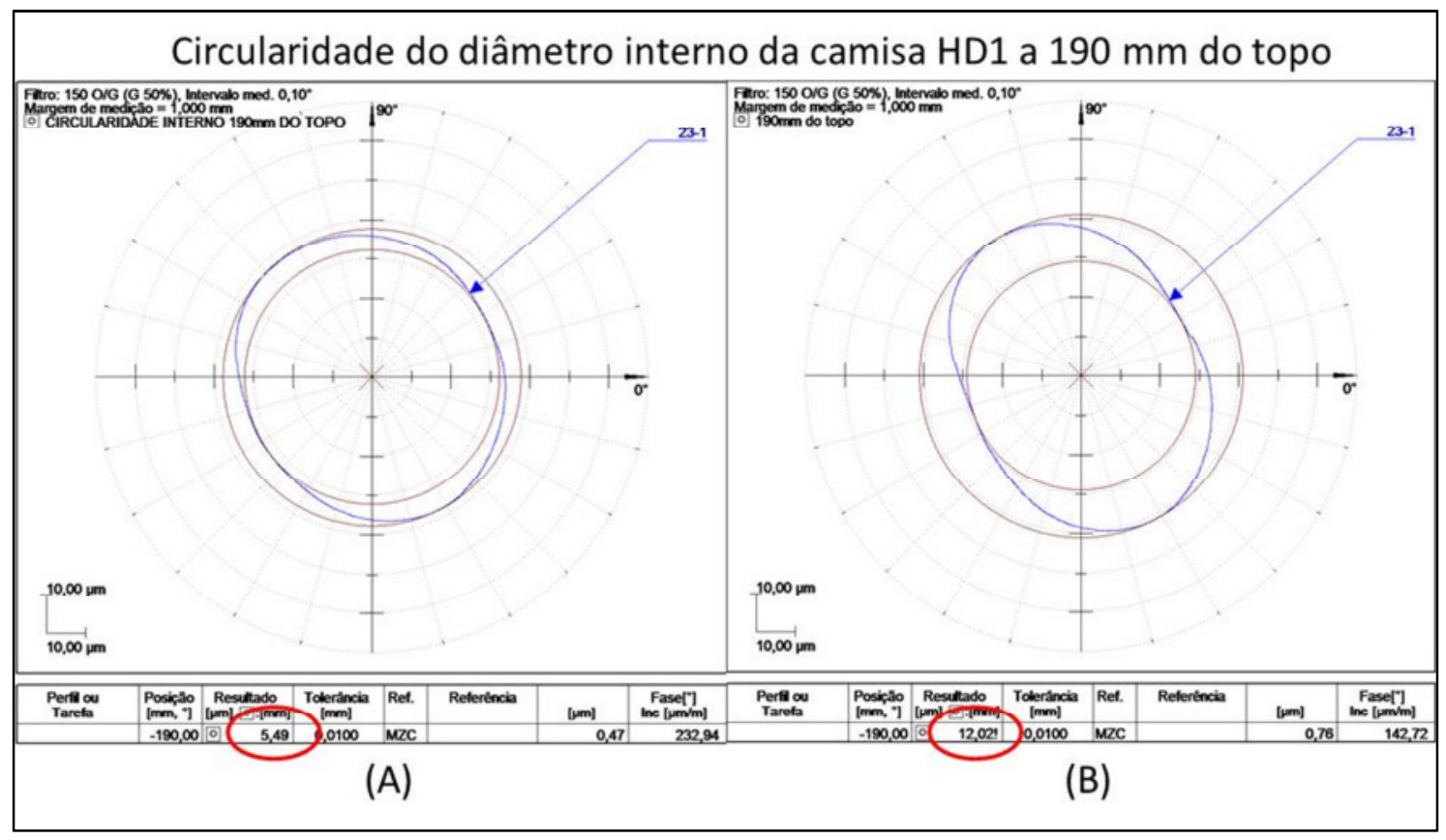

FIGURA 63 - Circularidade do diâmetro interno, camisa HD1. Altura 190 mm, (A) antes e (B) após a deposição do filme DLC.

Os resultados da medição de retitude, ou erro de retilineidade, do diâmetro interno estão compilados na TAB. 23. Assim como foi feito para a circularidade, a diferença foi calculada pelos valores medidos antes e após a deposição do filme DLC.

TABELA 23 - Retilineidade das camisas HD em $\mu \mathrm{m}$.

\begin{tabular}{cccccc}
\hline \multirow{2}{*}{ Identificação } & & \multicolumn{4}{c}{ Posicionamento angular } \\
& & 0.0 & $90^{\circ}$ & $180^{\circ}$ & $270^{\circ}$ \\
\hline \multirow{3}{*}{ Camisa HD1 } & Antes & 3,90 & 10,40 & 7,87 & 4,78 \\
& Depois & 4,01 & 7,92 & 8,96 & 4,48 \\
& Diferença & 0,11 & $-2,48$ & 1,09 & $-0,30$ \\
Camisa HD2 & Antes & 4,58 & 3,58 & 5,70 & 7,71 \\
& Depois & 3,80 & 3,52 & 5,91 & 8,44 \\
& Diferença & $-0,78$ & $-0,06$ & 0,21 & 0,73 \\
Camisa HD4 & Antes & 3,90 & 10,04 & 7,87 & 4,78 \\
& Depois & 4,01 & 7,92 & 8,96 & 4,48 \\
& Diferença & 0,11 & $-2,12$ & 1,09 & $-0,30$ \\
& Antes & 3,88 & 9,68 & 6,05 & 12,90 \\
Camisa HD6 & Depois & 6,02 & 11,78 & 3,88 & 12,77 \\
& Diferença & 2,14 & 2,10 & $-2,17$ & $-0,13$ \\
\hline
\end{tabular}


Para a retilineidade, o projeto da camisa HD define um limite máximo de $15 \mu \mathrm{m}$, limite este, respeitado por todas as camisas após receber o filme DLC. Nota-se que nas camisas HD1 e HD4, ocorreu aumento do erro de retilineidade nas posições angulares $0^{\circ}$ e $180^{\circ}$, não superando em $1,1 \mu \mathrm{m}$, e redução de até $2,5 \mu \mathrm{m}$ nas posições angulares $90^{\circ}$ e $270^{\circ}$ ao longo do comprimento da camisa. A camisa HD2 apresentou uma deformação inferior após processo de deposição, sendo que a diferença observada não superou $0,7 \mu \mathrm{m}$. Por outro lado, a camisa HD6 apresentou as maiores distorções longitudinal com aumento de até 2,1 $\mu \mathrm{m}$ nas posições angulares $0^{\circ}$ e $90^{\circ}$ e redução de até $2,2 \mu \mathrm{m}$ na posição angular $180^{\circ}$.

Perfis de traçagem representativos de todas as camisas HD são apresentados na FIG. 64 referente a camisa HD1 antes (A) e após (B) o processo de deposição do filme DLC.

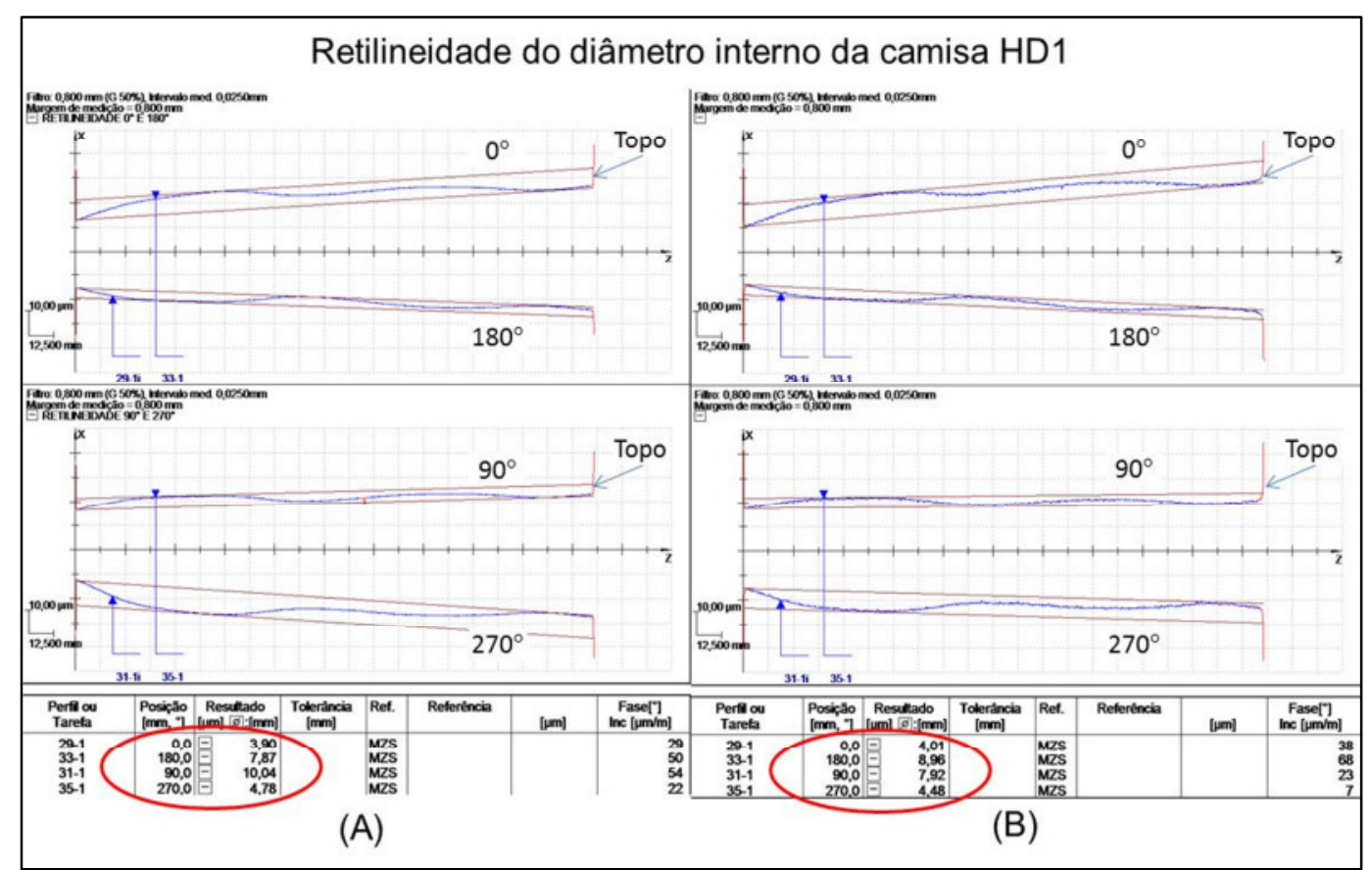

FIGURA 64 - Medição do erro de retilineidade da camisa HD1. (A) antes e (B) após a deposição do filme DLC.

De forma geral, se observou que os maiores desvios estão concentrados na região inferior das camisas $H D$, o que faz sentido em função do que se observou nas medições de circularidade. Comparando os valores de retilineidade é possível afirmar que o processo de deposição do filme DLC pouco afetou a 
distorção longitudinal das camisas HD, sendo que não é possível verificar uma tendência de crescimento ou redução.

A cilindricidade do diâmetro interno, que é composta de três componentes: erro de circularidade, erro de retitude e erro de paralelismo entre geratrizes opostas que formam a superfície do cilindro interno (NBR 6409, 1997; NBR ISO 2768-2, 2001), foi gerada a partir dos resultados anteriores de medição, circularidade e retilineidade. Com esta análise foi possível avaliar os valores máximos de deformação diametral ao longo do comprimento das camisas HD. A TAB. 24 apresenta a compilação de todos os resultados e a variação máxima observada na coluna "Diferença", que são calculados subtraindo os valores medidos antes a após a deposição do filme DLC.

TABELA 24 - Cilindricidade das camisas HD em $\mu \mathrm{m}$.

\begin{tabular}{ccc}
\hline Identificação & & \\
\hline \multirow{3}{*}{ Camisa HD \#1 } & Antes & 13,20 \\
& Depois & 21,86 \\
& Diferença & 8,66 \\
& Antes & 9,92 \\
Camisa HD \#2 & Depois & 11,53 \\
& Diferença & 1,61 \\
& Antes & 9,51 \\
Camisa HD \#4 & Depois & 10,48 \\
& Diferença & 0,97 \\
& Antes & 6,95 \\
Camisa HD \#6 & Depois & 15,91 \\
& Diferença & 8,96 \\
\hline
\end{tabular}

Na coluna diferença, os valores positivos significam que houve aumento do erro de cilindricidade.

Para o projeto da camisa HD, não existe uma especificação limite para a cilindricidade, portanto a analise feita foi feita na diferença observada antes $e$ após a deposição do filme DLC. A camisa HD1 e HD6 apresentaram as maiores diferenças de desalinhamento diametral ao longo do comprimento da camisa HD. Este fato já era esperado para a camisa HD1 por conta da variação observada durante as medições de circularidade e também para a camisa HD6 em função da maior variação observada nas medições de retilineidade. Esta analise final da circularidade se mostrou de fundamental importância para a qualificação das camisas de cilindro revestidas com filme DLC pelo processo de deposição 
PACVD. De acordo com TOMANIK (1996), valores aceitáveis para erro de cilindricidade em camisas com diâmetro interno similares as das camisas HD utilizadas no trabalho, devem permanecer na faixa de 11 a $24 \mu \mathrm{m}$, portanto os resultados finais obtidos estão conforme a recomendação. Perfis de traçagem da cilindricidade representativos para todas as camisas HD são apresentados nas FIG. 65 e 69 referente as camisas HD1 e HD6, antes (A) e após (B) o processo de deposição do filme DLC.

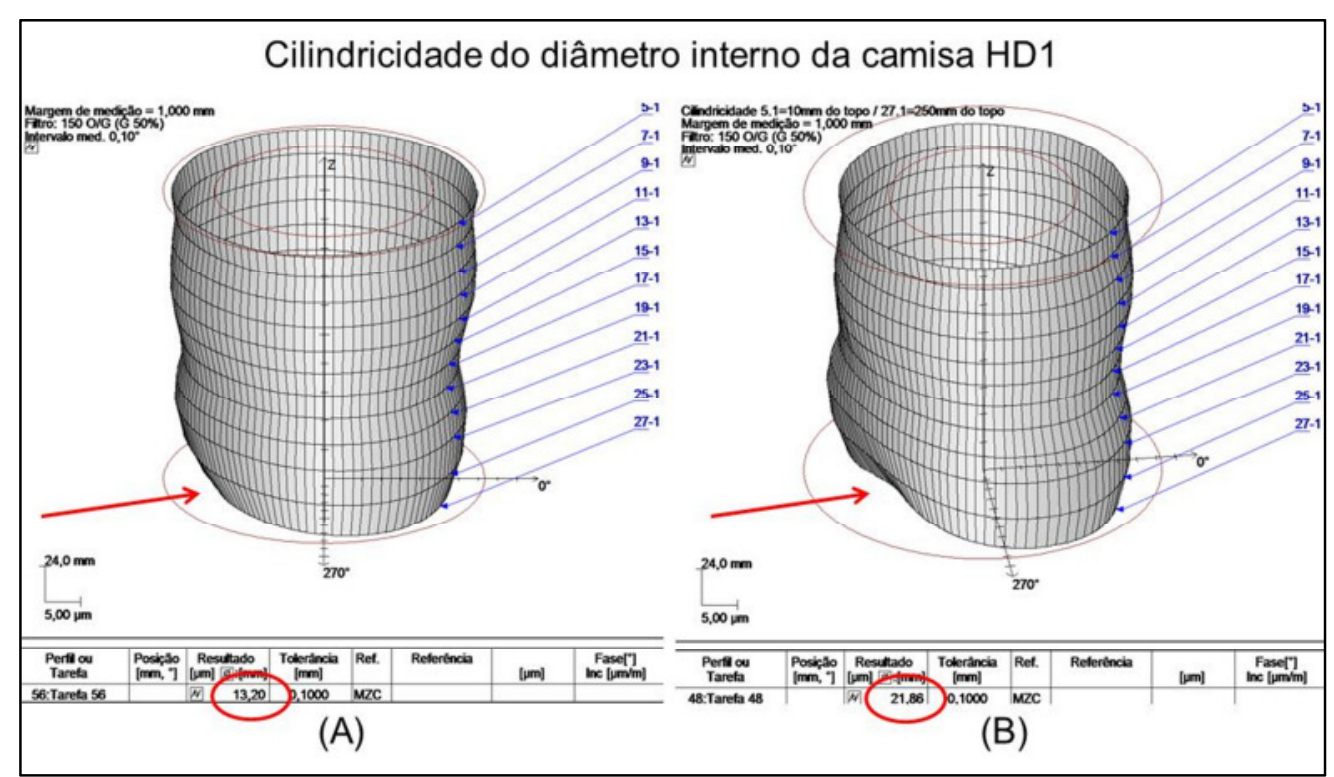

FIGURA 65 - Medição do erro de cilindricidade da camisa HD1. (A) antes e (B) após a deposição do filme DLC.

Pelo perfil da camisa HD1 na FIG. 65 é possível verificar o aumento da distorção diametral na região inferior entre os ângulos de $180^{\circ}$ e $270^{\circ}$. Este aumento pode estar relacionado a algum esforço localizado nesta região que se iniciou antes mesmo da etapa de deposição do filme DLC, ficando mais evidente após recebimento do filme.

Assim como na camisa HD1, a camisa HD6 também apresentou distorção diametral elevada após deposição do filme DLC. É possível observar na FIG. 66 uma ovalização maior localizada na metade inferior do comprimento, comportamento observado na medição anterior de retilineidade. De forma geral, todos os valores medidos antes e depois se encontram numa faixa aceitável para serem utilizadas em testes de motor (TOMANIK, 1996). 


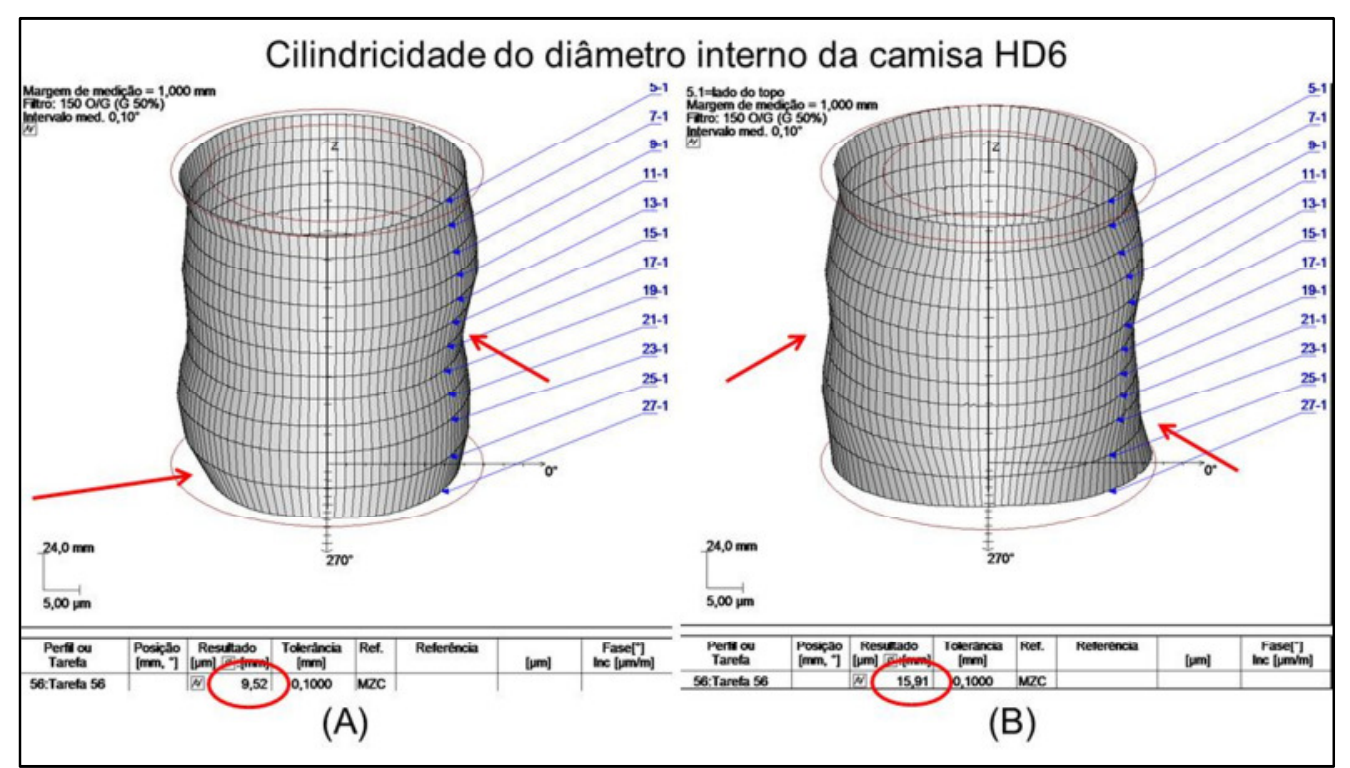

FIGURA 66 - Medição do erro de cilindricidade da camisa HD6. (A) antes e (B) após a deposição do filme DLC.

Devido à baixa temperatura do processo de deposição do filme DLC, em torno de $200^{\circ} \mathrm{C}$, e pelo fato de haver uma tendência de aumento na distorção radial em todas as camisas recobertas, se faz necessário uma investigação mais detalhada do processamento adotado na deposição do filme DLC, principalmente nas etapas de limpeza, acondicionamento e fixação do componente por haver necessidade de manuseio do operador e possibilidade de estocagem do componente de forma incorreta, pois é de conhecimento que pequenas batidas ou até mesmo acondicionamentos incorretos, como manter o componente posicionado na horizontal por longo período, afetam a distorção radial do componente.

\subsubsection{Medição da rugosidade da superfície interna}

Os resultados da medição de rugosidade na superfície interna das camisas HD antes e após a deposição do filme DLC estão compilados em tabelas nos APÊNDICES B, C, D e E. Com base nos valores médios calculados dos parâmetros de rugosidade da série Rk em diversas posições das camisas HD, a FIG. 67 monstra graficamente o comportamento desses parâmetros antes e após a deposição do filme DLC. Os resultados apontam que as camisas HD1 e HD2 apresentaram pequenas variações com uma tendência de aumento da 
rugosidade, principalmente influenciado pelo parâmetro Rk. As camisas HD4 e HD6 também apresentaram uma tendência de aumento da rugosidade com forte influência dos parâmetros Rpk e Rk. Entretanto, a camisa HD6 apresentou valores de Rvk bem abaixo das demais na altura de $30 \mathrm{~mm}$ de distância do topo mesmo na condição sem filme DLC, o que indica que esta camisa pode apresentar um desempenho diferenciado em testes de bancada ou de motor, uma vez que este parâmetro tende a controlar a quantidade de oferta de óleo para o deslizamento dos anéis de pistão, podendo inclusive impactar na taxa de desgaste dos componentes. De forma geral, os desvios observados estão dentro de uma normalidade de produção, ou seja, os desvios máximos não ultrapassam $20 \%$ dos valores médios calculados. A partir dessas observações, é possível concluir que o processo de deposição do filme DLC não afetou significativamente os parâmetros de rugosidade originais do substrato, entretanto, a superfície apresenta tendência de tornar-se mais rugosa.

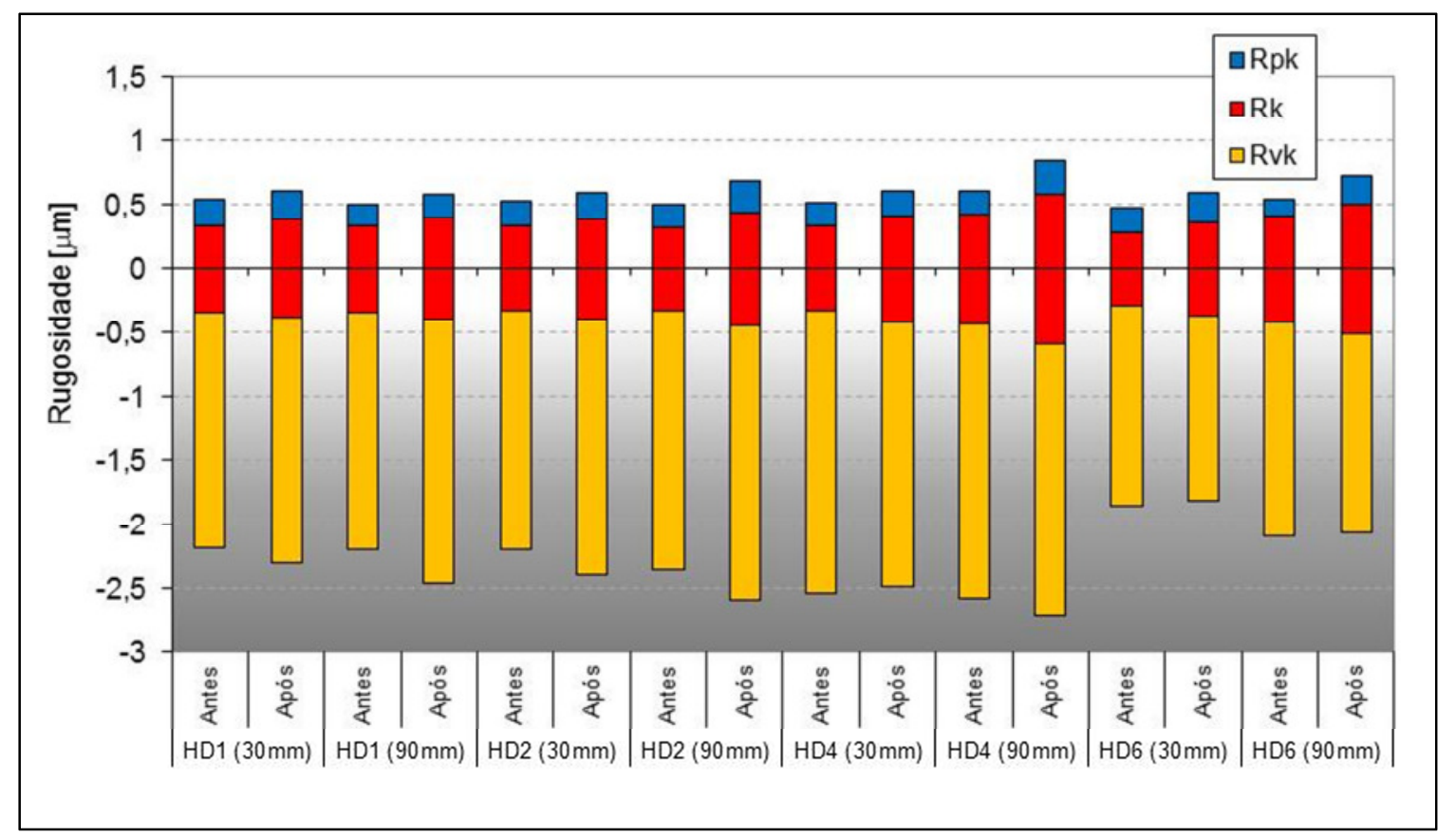

FIGURA 67 - Evolução dos parâmetros da série Rk antes e após deposição do filme DLC nas camisas HD.

Como complemento à qualificação do brunimento via medição 2D dos parâmetros de rugosidade, a réplica da superfície brunida foi gerada para todas as camisas HD, revelando as características da superfície brunida do substrato de 
ferro fundido e do filme DLC. Com auxilio do MO, imagens digitais foram geradas a partir das análises dos acetados com as réplicas de cada superfície brunida, como mostram as FIG. 68, 69, 70 e 71. Com base nessas figuras foi possível verificar que o padrão dos canais de brunimento após receber o filme DLC se encontra preservado, ou seja, não foram observadas alterações na quantidade e na qualidade dos canais cruzados do brunimento assim como o ângulo formado entre eles, o que sugere que o processo de deposição PACVD adotado pelo trabalho não prejudicou a qualidade da superfície rugosa das camisas HD.

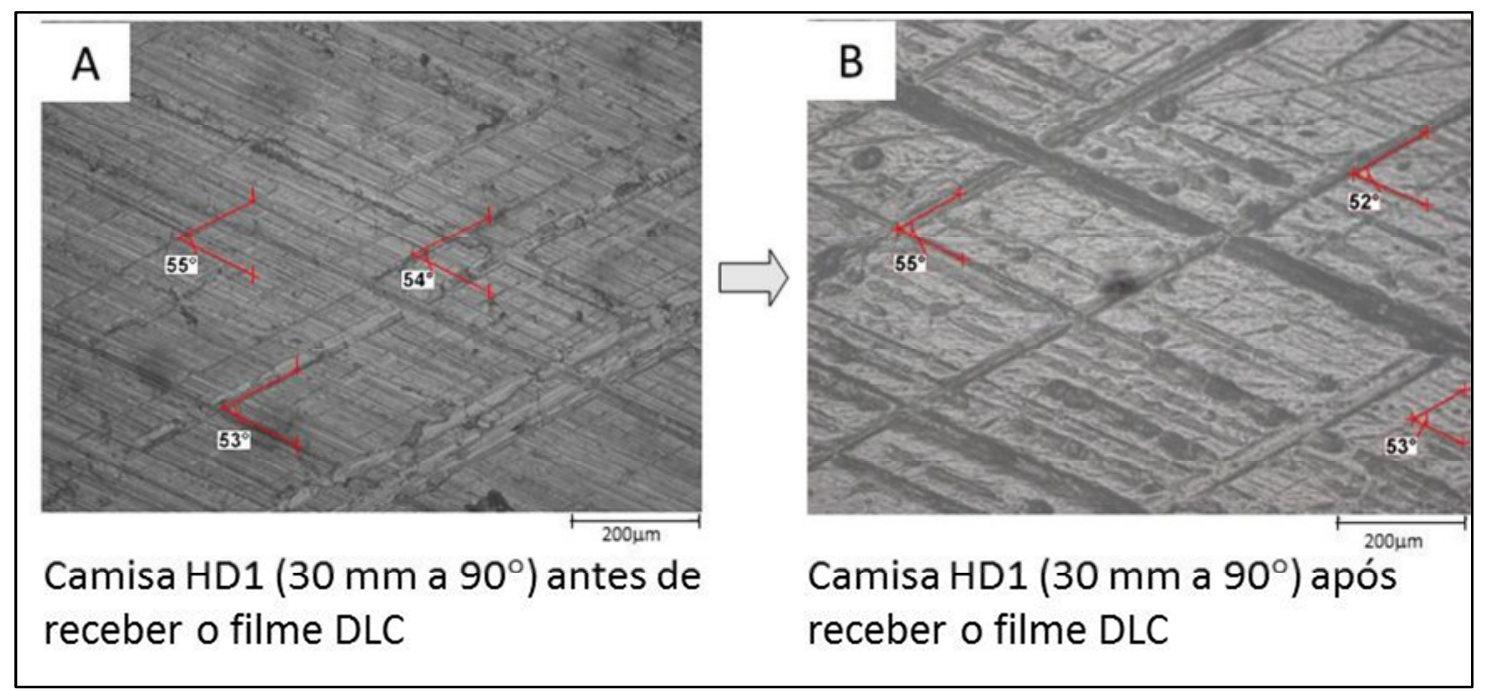

FIGURA 68 - Réplica da superfície brunida da camisa HD1 a 30 mm e $90^{\circ}$. (A) sem filme DLC. (B) com filme DLC.

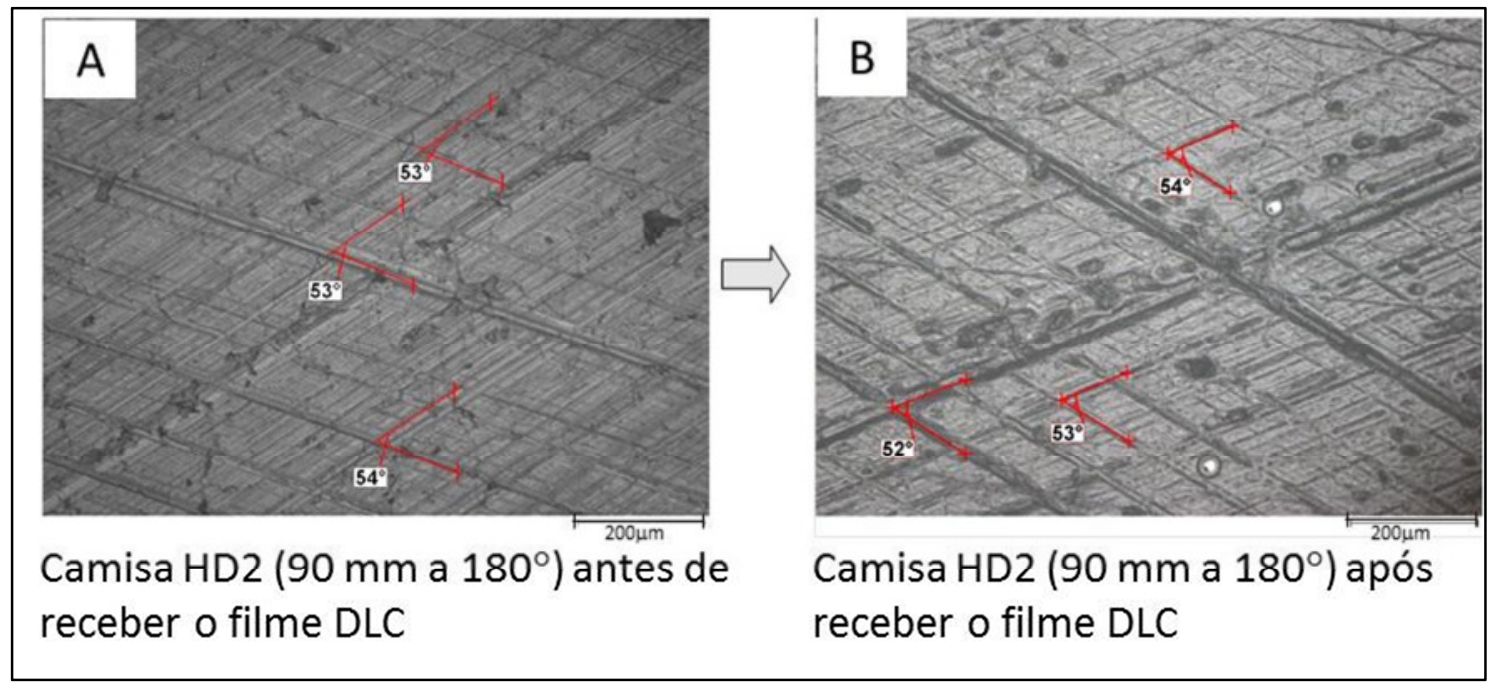

FIGURA 69 - Réplica da superfície brunida da camisa HD2 a 90 mm e $180^{\circ}$. (A) sem filme DLC. (B) com filme DLC. 


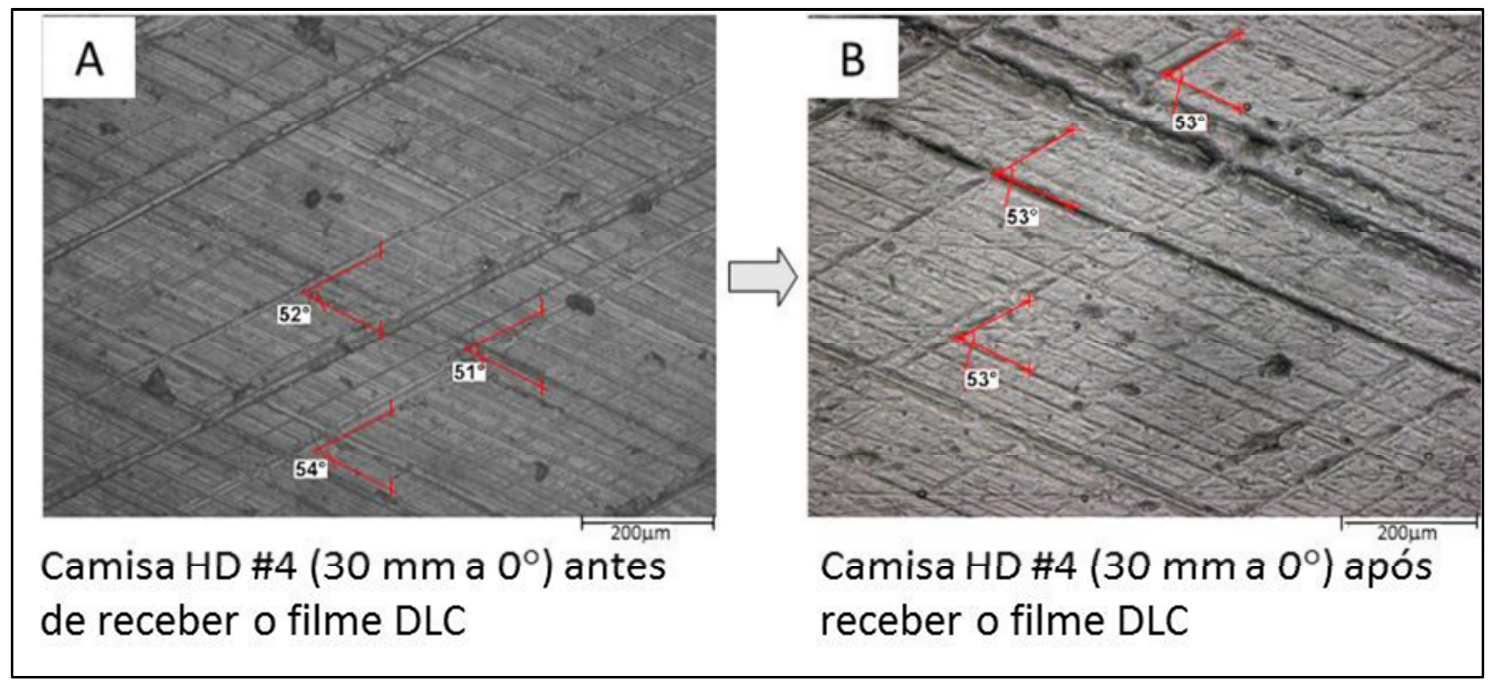

FIGURA 70 - Réplica da superfície brunida da camisa HD4 a 30 mm e $180^{\circ}$. (A) sem filme DLC. (B) com filme DLC.

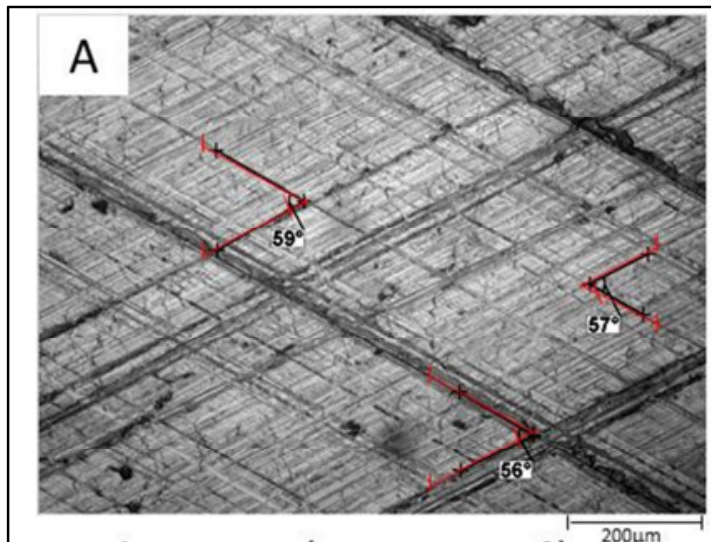

Camisa HD \#6 $\left(30 \mathrm{~mm}\right.$ a $\left.90^{\circ}\right)$ antes de receber o filme DLC

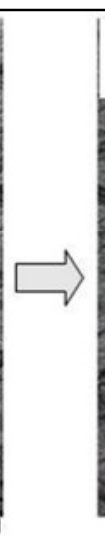

Camisa HD \#6 (30 $\mathrm{mm}$ a $\left.90^{\circ}\right)$ apos
receber o filme DLC

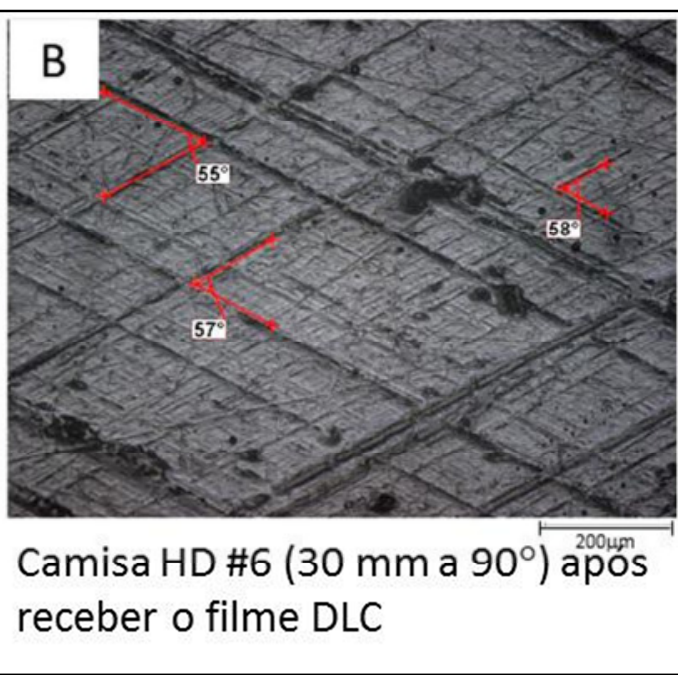

FIGURA 71 - Réplica da superfície brunida da camisa HD6 a 30 mm e $90^{\circ}$. (A) sem filme DLC. (B) com filme DLC.

Após a consolidação dos resultados dimensionais e das informações provenientes do estudo da réplica do brunimento, observa-se que o processo de deposição PACVD tende a aumentar o nível de distorção das camisas e proporcionar uma rugosidade da superfície interna ligeiramente maior do que a rugosidade anteriormente observada no substrato de ferro fundido. Entretanto, não se observou nenhum problema quanto a imperfeições de recobrimento, e o filme se apresenta de forma homogênea em toda a extensão recoberta da superfície interna. 


\subsubsection{Análise microestrutural do filme DLC}

A caracterização do filme DLC por MEV foi conduzida na metade das camisas HD1 e HD4 denominada lado A. Os corpos-de-prova da seção transversal foram retirados de três alturas a partir da face de topo: 20, 150 e 220 mm. As FIG. 72 e 73 apresentam imagens da secção transversal das amostras obtidas por MEV, nas três alturas definidas para cada espessura de filme.

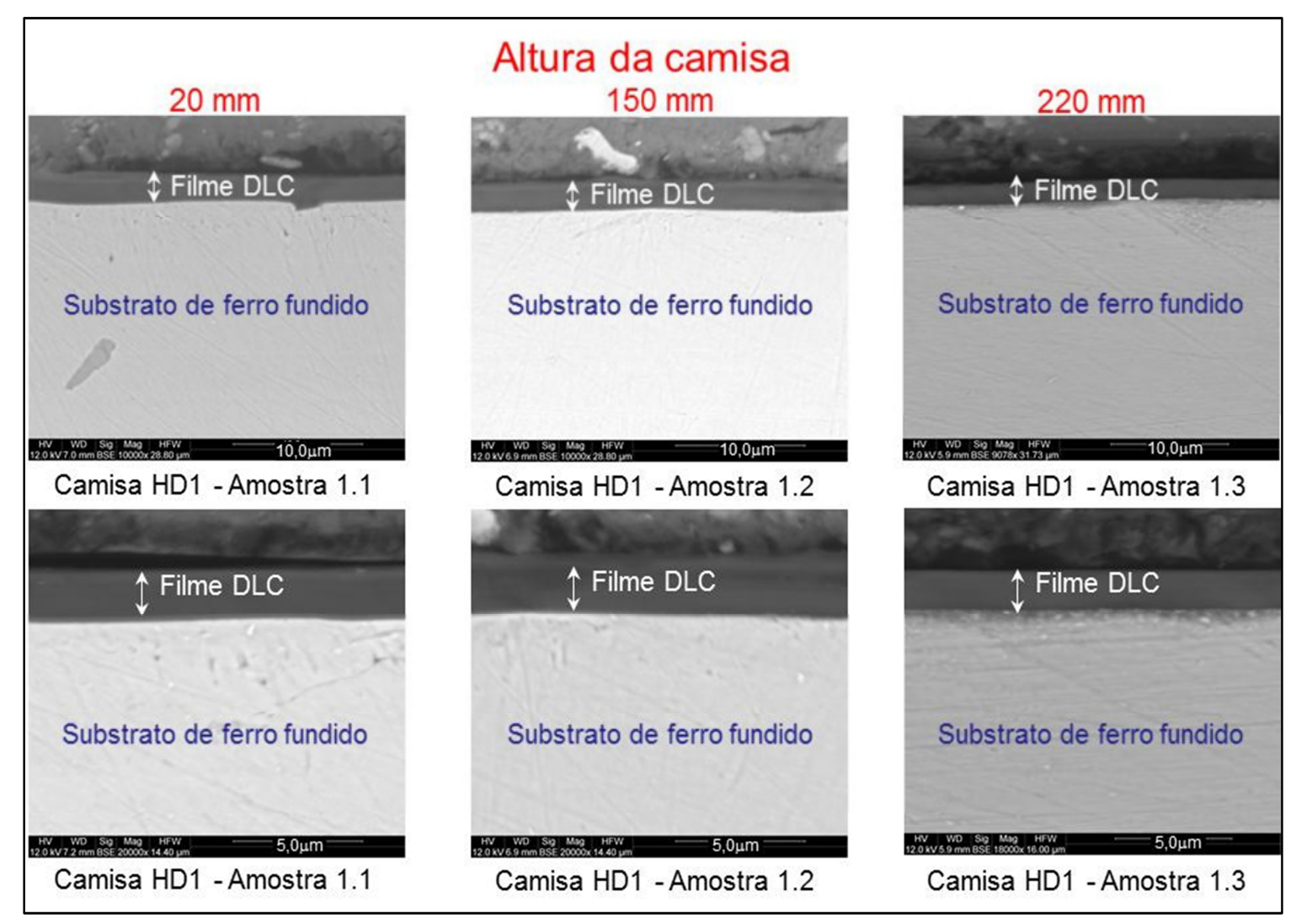

FIGURA 72 - Imagens MEV, camisa HD1 (imagens por elétrons retroespalhados).

As imagens MEV da camisa HD1 mostram a região de interface entre o substrato de ferro fundido e do filme DLC homogênea sem a presença de imperfeições. A espessura do filme esta de acordo com os valores nominais de 2,5 $\mu \mathrm{m}$, estabelecidos para a camisa HD1. 


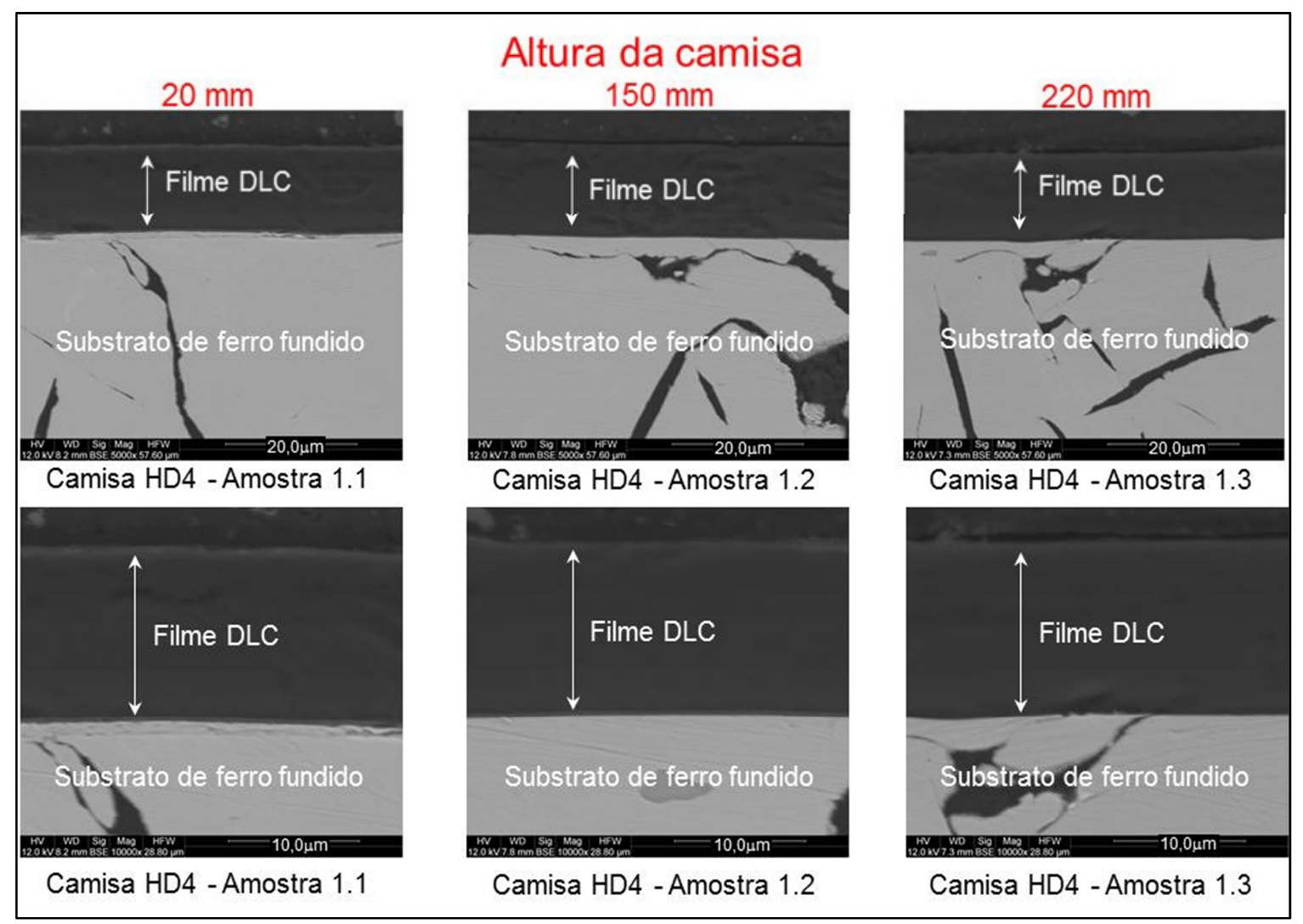

FIGURA 73 - Imagens MEV, camisa HD1 (imagens por elétrons retroespalhados).

As imagens por MEV da camisa HD4 também mostram uma região de interface entre o substrato de ferro fundido e o filme DLC homogênea, sem a presença de imperfeições. A espessura medida no momento de registro das fotos confirmou valores próximos aos nominais de 12,5 $\mu \mathrm{m}$ estabelecidos para a camisa HD4.

Outra questão importante observada durante as análises de MEV é que o filme DLC tende a acompanhar a rugosidade do substrato, que mostra que estar em acordo com as análises de medição da rugosidade do brunimento, onde se verificou que o filme DLC tende a manter um nível de rugosidade muito similar ao do substrato. A FIG. 74 apresenta algumas imagens da camisa HD6 onde é possível observar certa ondulação no substrato de ferro fundido, ilustrado pelas setas em amarelo, e logo acima o filme DLC acompanhando a geometria desta ondulação com setas em branco. 


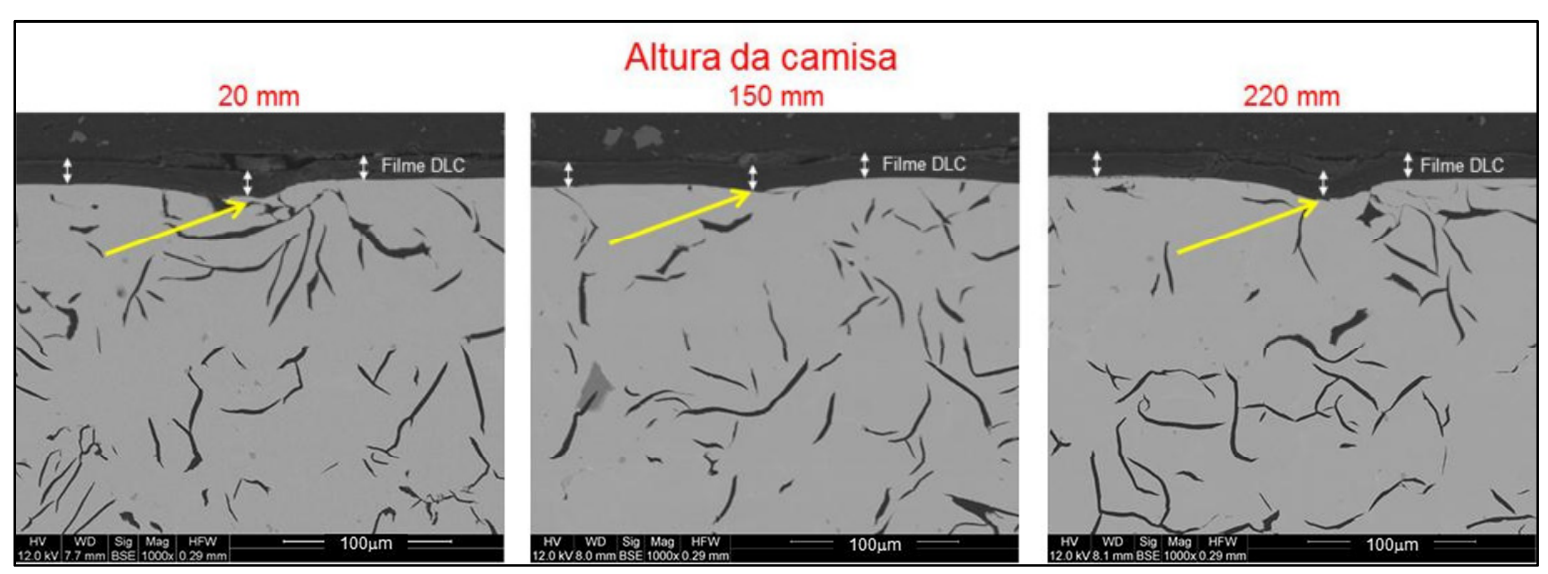

FIGURA 74 - Filme DLC acompanhando as imperfeições do substrato pela análise MEV (imagens por elétrons retro-espalhados).

As análises semiquantitativas via EDS em linha avaliaram a presença dos microconstituintes ao longo da espessura dos filmes DLC, partindo do substrato até a superfície interna da camisa conforme mostram as FIG. 75 e 76, para as camisas HD1 e HD4, respectivamente.

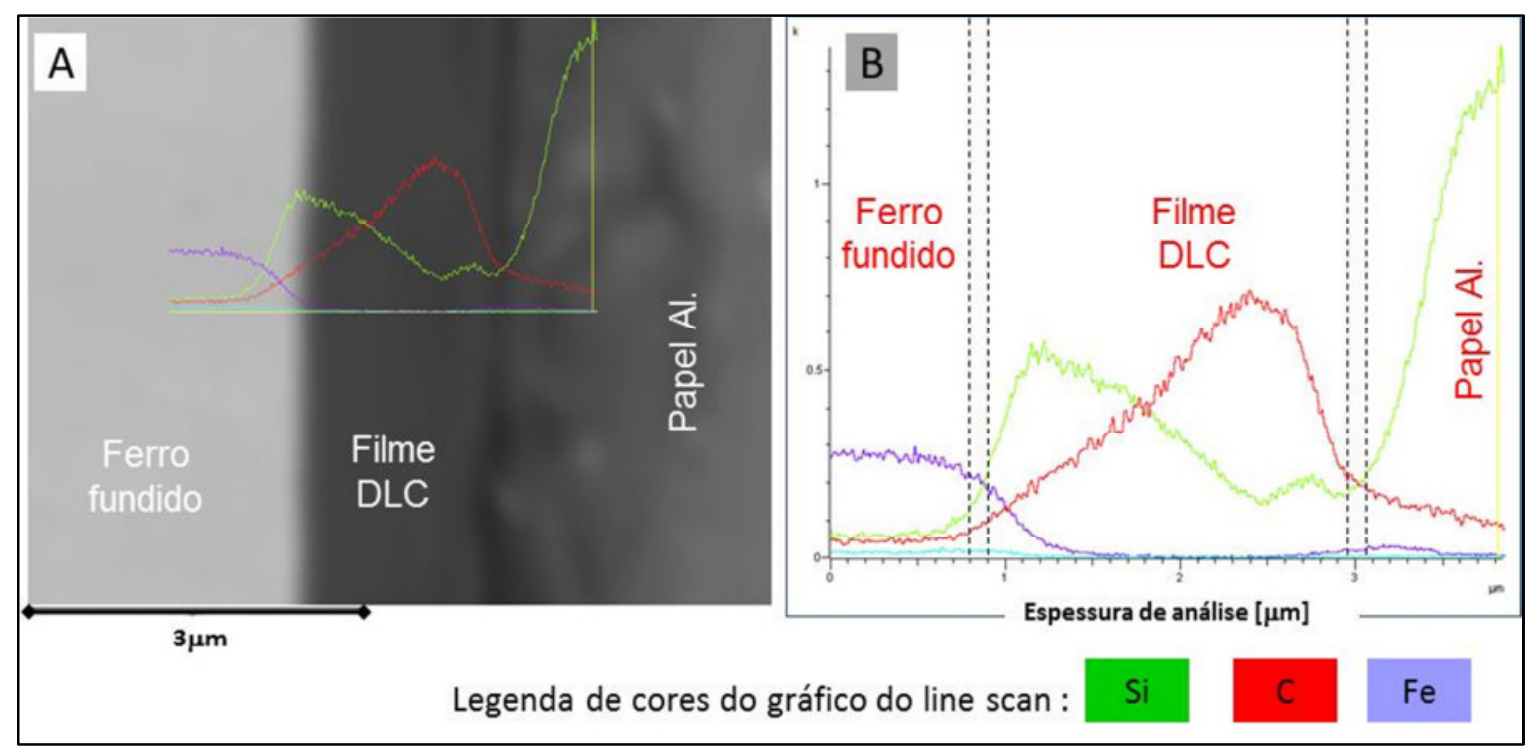

FIGURA 75 - (A) Imagem da seção transversal obtida por MEV e (B) perfil da composição química semiquantitativa da camisa HD1 obtido por EDS. 


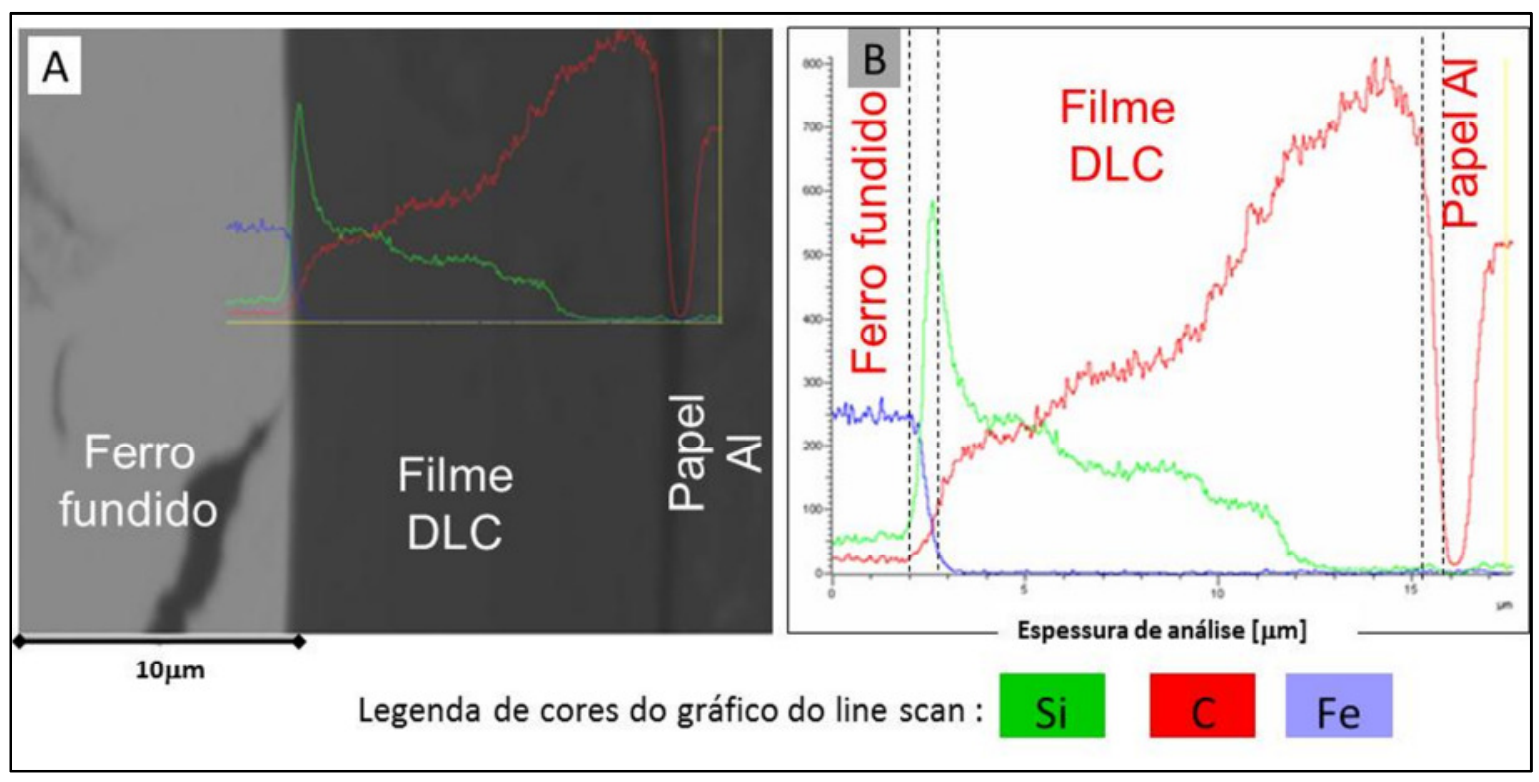

FIGURA 76 - (A) Imagem da seção transversal obtida por MEV e (B) perfil da composição química semiquantitativa da camisa HD4 obtido por EDS.

As análises por EDS em linha confirmam a presença dos elementos químicos silício e carbono na secção transversal do filme DLC. Observa-se um gradiente crescente de carbono em direção à superfície de trabalho e decrescente para o elemento silício, o que caracteriza um filme com gradiente de composição química, conforme informado no item 4.3, FIG. 45. Linhas tracejadas para definir uma zona de transição por conta da possibilidade de existir zonas de difusão foram inseridas nas FIG. 75 e 76 para identificar as regiões de transição entre o substrato e o inicio do filme DLC e a superfície de trabalho das camisas HD que indica o término do filme DLC.

\subsubsection{Difração de raios- $X$}

O padrão de difração do material da camisa referência, que é um ferro fundido cinzento perlítico e das camisas revestidas HD1 e HD4 são apresentados em diferentes difratogramas nas FIG. 77, 78, e 79. A indexação dos principais planos cristalográficos de cada difratograma foi feita utilizando-se a ficha JCPDS (“Joint Committee on Power Diffraction Standards"). 


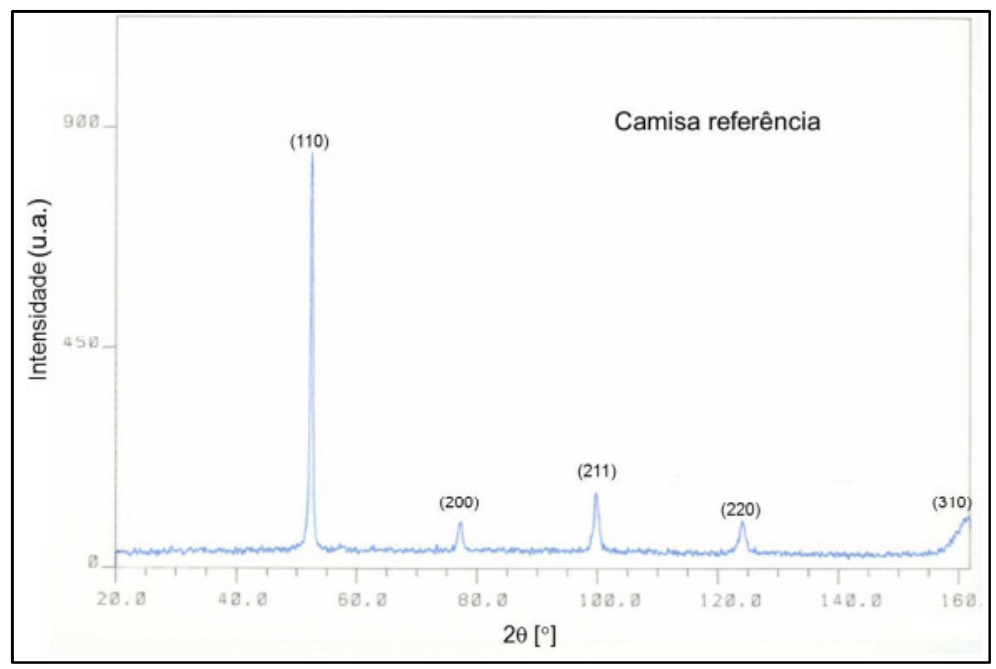

FIGURA 77 - Difratograma da camisa referência.

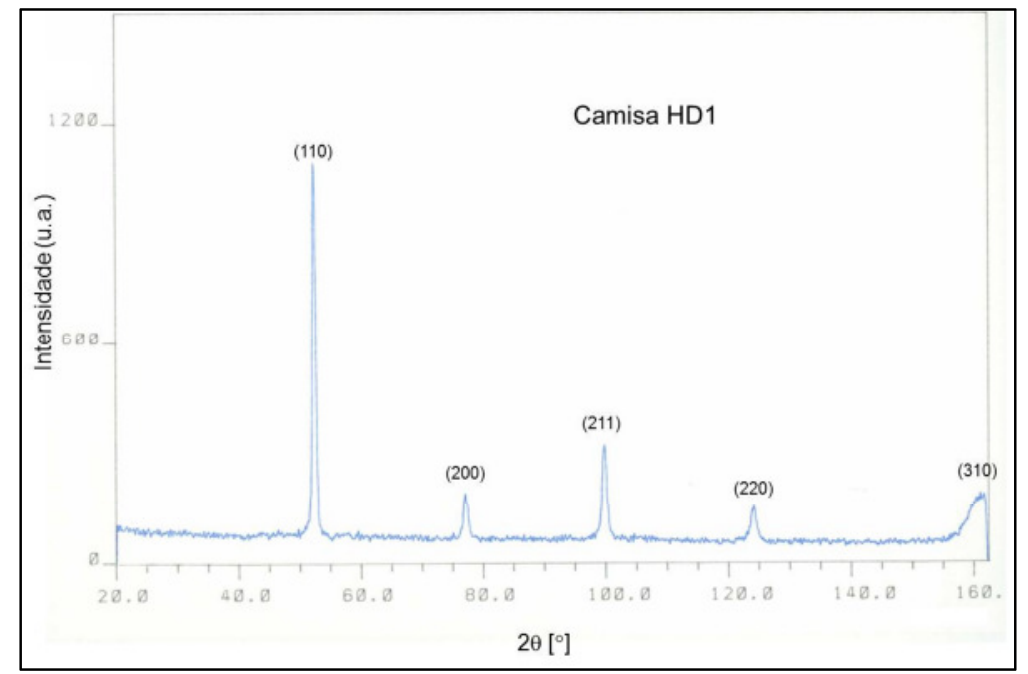

FIGURA 78 - Difratograma da camisa HD1.

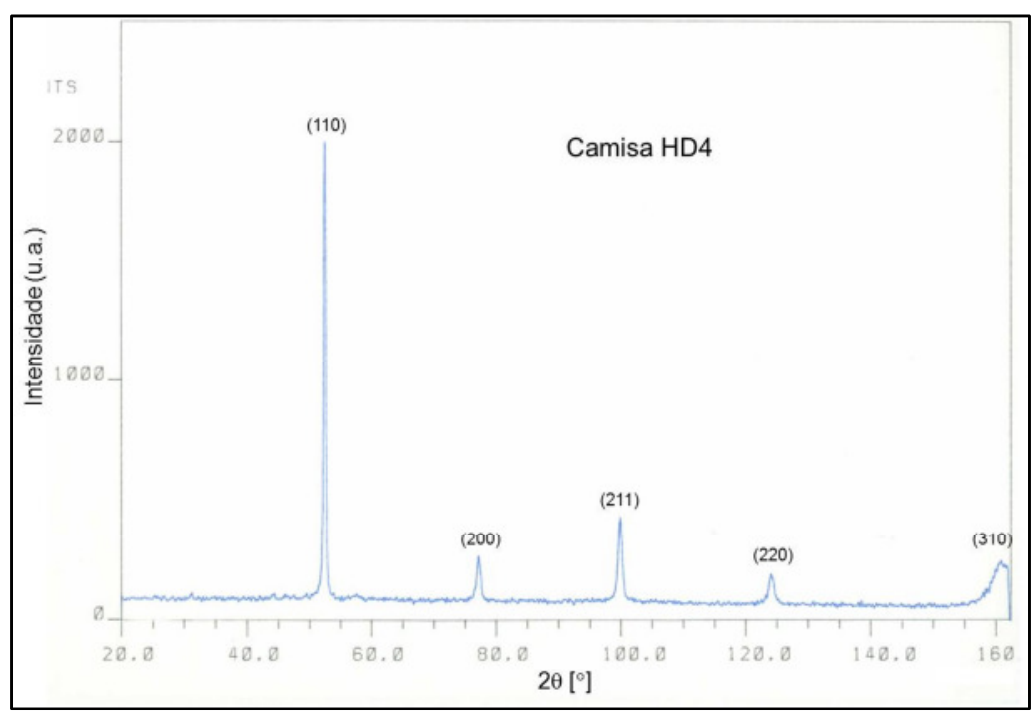

FIGURA 79 - Difratograma da camisa HD4. 
É possível verificar a semelhança entre os três difratogramas, os quais sugerem que o filme DLC possui uma estrutura amorfa.

Como é de conhecimento, os planos cristalográficos, referenciados pelos índices de Miller, e suas respectivas distâncias interplanares, bem como as densidades de átomos ao longo de cada plano cristalino, são características específicas e únicas de cada substância cristalina, da mesma forma que o padrão difratométrico por ela gerado que é equivalente a uma impressão digital. Analisando os difratogramas por raios- $x$ e comparando os picos num banco de dados que contém informações cristalográficas básicas e algumas propriedades físicas de compostos cristalinos, mantido e continuamente atualizado pelo ICDD, International Center for Diffraction Data, com sede nos EUA, foi possível observar os picos da $\alpha$-ferrita com índices (110) e (200). Isto indica que os três difratogramas de referem a estrutura do Fe- $\alpha$ (ICDD 6-0696), que é o material de substrato das camisas HD (KESAVAN e AZAD, 2008).

\subsubsection{Dureza do filme DLC}

A TAB. 25 mostra os resultados das propriedades mecânicas para os filmes DLC das camisas HD1 e HD4.

TABELA 25 - Propriedades mecânicas do filme DLC

\begin{tabular}{lcc}
\hline \multicolumn{1}{c}{ Propriedades mecânicas } & Camisa HD1 & Camisa HD4 \\
\hline Módulo de elasticidade reduzido [GPa] & $158,3 \pm 7,36$ & $87,7 \pm 6,0$ \\
Módulo de elasticidade [GPa] & $167,2 \pm 8,9$ & $86,5 \pm 6,5$ \\
Dureza [GPa] & $17,1 \pm 1,9$ & $11,0 \pm 1,0$ \\
\hline
\end{tabular}

A profundidade da nanoindentação de $200 \mathrm{~nm}$ para o filme DLC da camisa HD1 e de $1.000 \mathrm{~nm}$ para camisa HD4 estão condizentes com a literatura (OLIVER e PAHRR, 1992), ou seja, não ultrapassaram 10\% da espessura total do filme e, portanto, não se espera influência do substrato. Tomando como referência o valor de dureza informado pela empresa responsável pela deposição do filme que é de 15 a $20 \mathrm{Gpa}$. O valor de dureza obtido para o filme DLC mais fino, camisa HD1 $(2,5 \mu \mathrm{m})$, atendeu as expectativas. Entretanto, o filme mais espesso, camisa HD4 $(12,5 \mu \mathrm{m})$, apresentou valores abaixo da faixa esperada. Na 
literatura, diversos trabalhos relatam que a análise de nanoindentação de filmes finos à base de carbono é complexa e delicada, sendo que a maioria dos valores de dureza de referência é obtida em corpos-de-prova planos (CHARITIDIS, 2010), o que não ocorreu neste trabalho. Os filmes DLC apresentam tensões na camada, que variam de acordo com o processo de deposição, a morfologia, a espessura e a relação das ligações $\mathrm{sp}^{2} / \mathrm{sp}^{3}$. As ligações $\mathrm{sp}^{3}$ promovem aumento das tensões na camada do filme DLC e se agravam em filmes mais espessos, comprometendo

a aderência do filme ao substrato e a dureza, enquanto que as ligações $\mathrm{sp}^{2}$ reduzem o nível de tensão, (CHARITIDIS, 2010; ROBERTSON, 2002). Investigações complementares a este trabalho para verificar a tensão residual no filme DLC mais espesso são recomendadas para se chegar a um melhor entendimento da queda de dureza observada.

\subsubsection{Coeficiente de atrito (COF) em bancada de teste recíproco de contato}

A FIG. 80 apresenta o comportamento do COF em cada condição de teste estabelecida no item 4.6, TAB. 14. Os valores de COF considerados nos gráficos são valores médios em módulo calculados a partir dos valores de pico encontrados em ambos os sentidos de deslizamento do anel de pistão com face de contato abaulado para cada experimento válido (TOMANIK, 2008). A base de dados que gerou os valores médios de COF está disponível em tabelas nos APÊNDICES F, G, e H. Na FIG. 80, cada gráfico apresenta uma condição de teste, sendo os do grupo A os testes conduzidos na condição de carregamento normal de $50 \mathrm{~N}$ e os do grupo B com $100 \mathrm{~N}$. Em cada condição de carregamento o comportamento do COF das três variantes é apresentado em função do tempo de teste acumulado caracterizado pelos índices $0 \mathrm{~h}, 2 \mathrm{~h}$ e $4 \mathrm{~h}$.

É possível verificar em todos os testes que os valores de COF obtidos mantêm comportamento similar de redução à medida que se aumenta a velocidade (velocidade recíproca) do corpo de prova da camisa instalado no suporte inferior do equipamento de teste. Os valores de COF obtidos com o filme DLC são inferiores aos medidos com a camisa referência, principalmente na região de menor velocidade, a redução do COF observada foi de até $19 \%$ com o filme DLC mais fino, presente na camisa HD1 $(2,5 \mu \mathrm{m})$. 


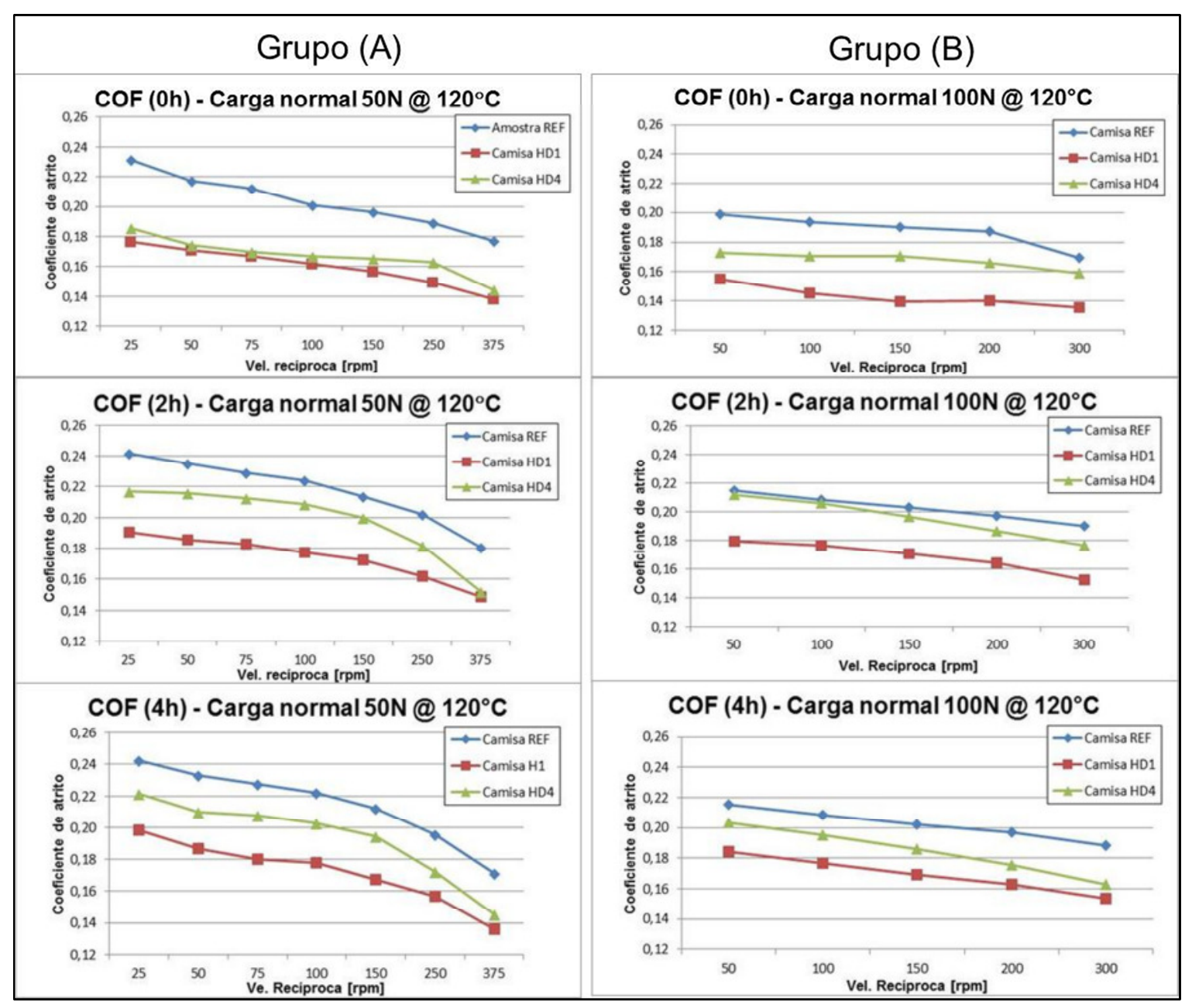

FIGURA 80 - Resultados do COF para temperatura de óleo $120^{\circ} \mathrm{C}$. (A) COF com carga normal de $50 \mathrm{~N}$, (B) COF com carga normal de $100 \mathrm{~N}$.

Quando as condições de lubrificação atingem o regime de lubrificação limite (velocidade recíproca/carga norma $\rightarrow 0$ ) a contribuição do filme DLC é expressivamente alta, principalmente para o filme mais fino na camisa HD1. Valores de COF nesta condição para a camisa referência variaram entre 0,23 a 0,24 para a condição de carregamento de $50 \mathrm{~N}$ e entre 0,20 a 0,22 para carregamento de $100 \mathrm{~N}$ estando acima dos valores publicados por TOMANIK (2008) que realizou testes similares porem a temperatura ambiente. Muito provavelmente os valores de COF maiores encontrados neste trabalho foram influenciados pela maior temperatura do óleo lubrificante atuante, o que contribuiu para a redução da sua viscosidade e, portanto maior contato metal-metal entre as partes. Informações das propriedades físico-químicas do óleo SAE30 utilizado nos testes a temperatura ambiente e a $260^{\circ} \mathrm{C}$ estão disponíveis no APÊNDICE I. Os 
valores de COF vinculados aos filmes DLC estão bem alinhados com outros trabalhos (DONNET e GRILL, 1997; GRILL, 1998) que defendem uma faixa de valor entre 0,1 a 0,4, porem em ar ambiente. A falta de publicações considerando o mesmo tipo de filme DLC e condições de ensaio tribológico similares ao executado no trabalho dificultou a realização de analises comparativa.

Mesmo em regimes que tendem para o hidrodinâmico 0 COF apresentou redução significante em relação a camisa referência, o que pode indicar uma forte contribuição para a redução de atrito no motor quando medido a pressão média efetiva de atrito exercida pelo pistão contra as paredes do cilindro. de lubrificação As FIG. 81, 82 e 83 proporcionam uma visualização dos corposde-prova de camisas e dos respectivos segmentos de anel de pistão após a conclusão dos ensaios de bancada de medição do COF.

É possível verificar que os padrões de contato das camisas de referência e dos respectivos anéis de pistão estão bem distribuídos demonstrando que a fixação e o alinhamento da máquina estavam adequados. Uma forte marcação na região de contato das camisas estabelece a área de contato do anel que é o curso desenvolvido pelo equipamento recíproco.

Os aspectos visuais dos corpos-de-prova das camisas referência mostram um padrão de contato forte na região de trabalho do anel de pistão bem homogêneo, o que sugere um bom alinhamento do sistema durante a aplicação do carregamento normal, suportando a geração de resultados de COF confiáveis.

As micrografias dos corpos-de-prova das camisas HD1 com filme DLC mais fino apresentam alguns pontos mais claros e brilhantes ao longo da superfície de contato com o anel de pistão, o que sugere ser uma revelação parcial do substrato de ferro fundido. Entretanto, não se observou evidências de delaminação por conta de má qualidade da aderência do filme DLC. Análises mais detalhadas mostraram que ocorreu um desgaste do filme e o substrato foi revelado, sendo mais intenso nas regiões de reversão do anel, onde se espera uma lubrificação menos eficiente, devido à baixa velocidade de deslocamento do anel de pistão (TOMANIK, 2008). Mesmo ocorrendo desgaste do filme DLC em alguns pontos da região de contato, o padrão de contato nos corpos-de-prova das camisas de cilindro e dos segmentos de anéis foi adequado para análise do COF. 


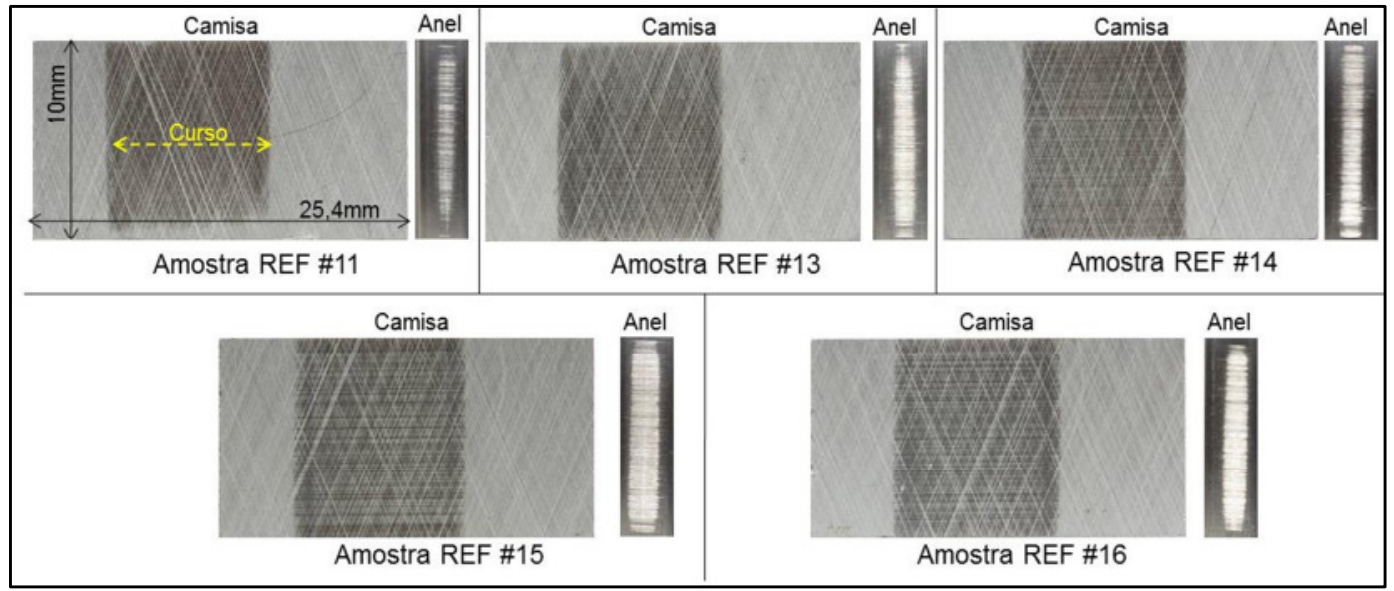

FIGURA 81 - Imagens por MO dos corpos-de-prova após teste de bancada recíproca, camisas referência.

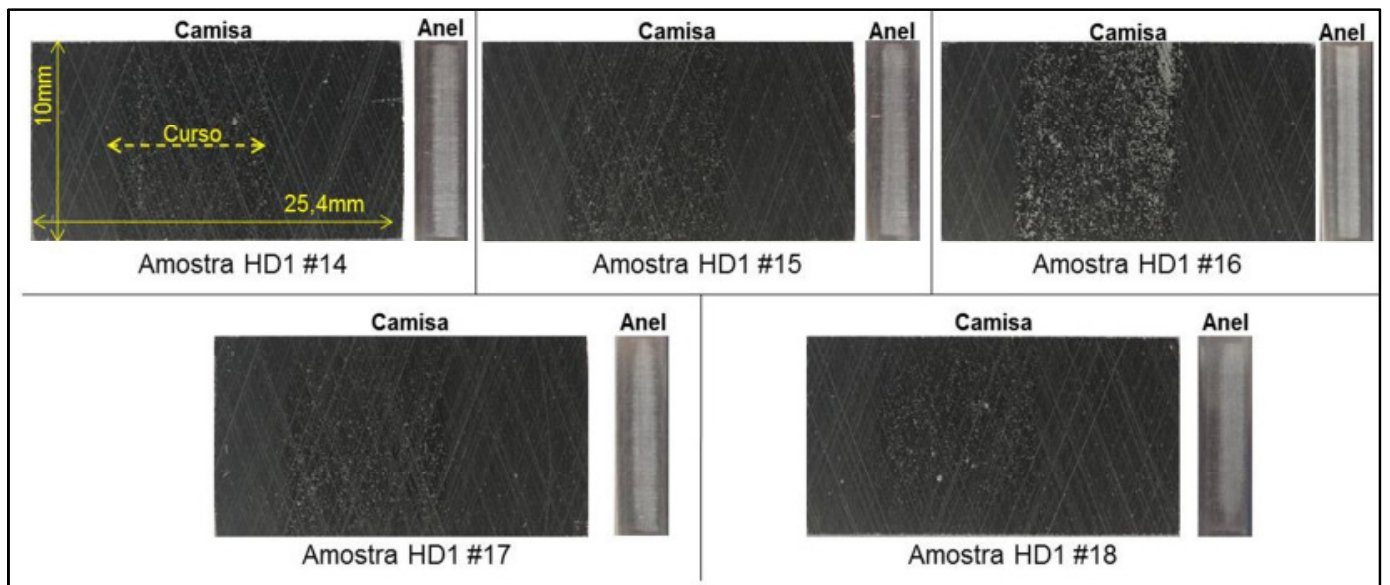

FIGURA 82 - Imagens por MO dos corpos-de-prova após teste de bancada recíproca, camisas HD1 $(2,5 \mu \mathrm{m})$.

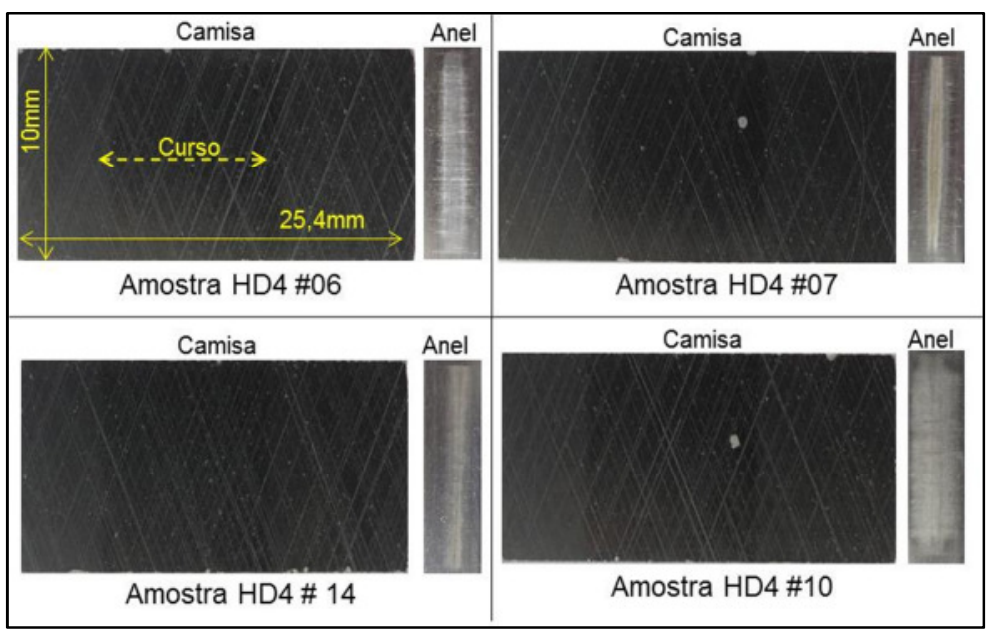

FIGURA 83 - Imagens por MO dos corpos-de-prova após teste de bancada recíproca, camisas HD4 (12,5 $\mu \mathrm{m})$. 
As micrografias dos corpos-de-prova das camisas HD4 apresentaram um aspecto visual muito bom do filme DLC, sendo muito difícil localizar o ponto de reversão do anel de pistão assim como pequenas regiões localizadas que sugerem um desgaste maior do filme DLC, e que revelam o substrato de ferro fundido.

\subsubsection{Durabilidade do filme DLC - Recomendação de espessura do DLC}

A durabilidade do filme DLC avaliada em teste padrão de durabilidade no motor ciclo Diesel em banco de prova acoplado em um dinamômetro foi conduzido com as camisas HD2 (2,5 $\mu \mathrm{m})$ e HD6 (12,5 $\mu \mathrm{m})$ montadas nas posições de cilindros \#5 e \#6, e nas demais posições foram montadas camisas referência. $\mathrm{O}$ motor completou as primeiras $10 \mathrm{~h}$ do ciclo de amaciamento e foi desmontado parcialmente (conjunto do cabeçote) para inspeção visual das camisas revestidas com filme DLC. Visualmente constatou-se que a camisa HD6, com filme DLC mais espesso de $12,5 \mu \mathrm{m}$, não apresentava mais a presença do filme DLC na região de trabalho dos anéis, conforme mostra a FIG. 84, sugerindo que ocorreu delaminação, pois o substrato com os sinais de brunimento estavam preservados. Todas as camisas foram removidas do motor para registro de fotos e medição do perfil de desgaste apresentado na região TDC, região mais crítica para as camisas por conta do rompimento do filme de óleo devido à velocidade de deslizamento dos anéis tender a zero. Para um melhor diagnostico do ocorrido com o filme DLC na camisa HD6, decidiu-se desmontá-la do motor e efetuar a substituição por uma camisa referência no cilindro \#6. A camisa HD2, montada no cilindro \#2 não apresentou nenhum sinal de delaminação e o seu aspecto visual se mostrou preservado, então foi mantida. $O$ motor foi fechado e ligado para completar 500 horas de rodagem conforme ciclo de durabilidade descrito no item 4.8, TAB. 18. 


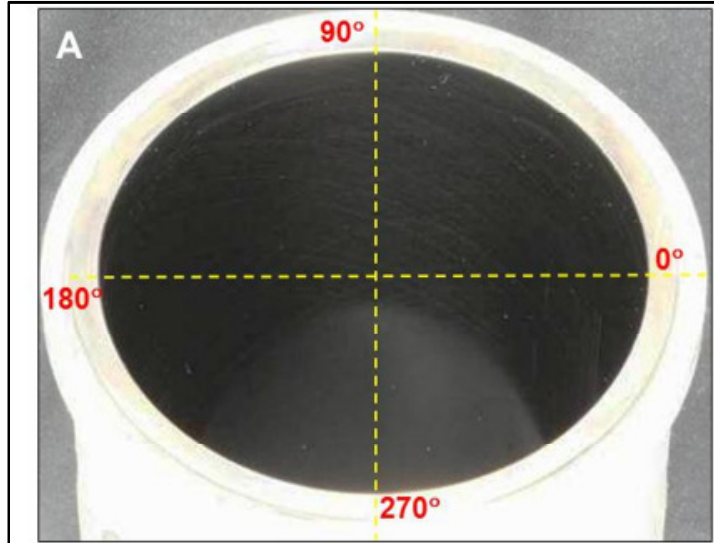

Camisa HD2 montada na posição \#5 do motor (DLC 2,5 $\mu \mathrm{m}$ )

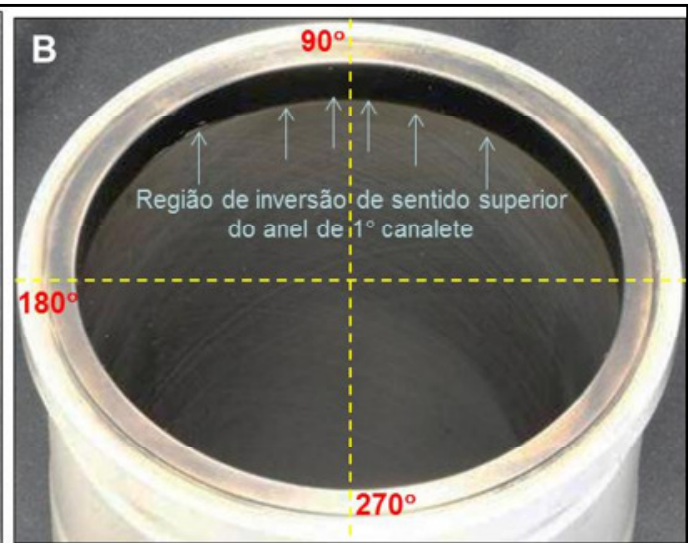

Camisa HD6 montada na posição \#6 do motor (DLC 12,5 $\mu \mathrm{m}$ )

FIGURA 84- Aspectos visuais das camisas HD2 (A) e HD6 (B) após 10 $\mathrm{h}$ de rodagem no ciclo de amaciamento.

A FIG. 85 mostra os resultados de medição do perfil de desgaste na região TDC das camisas revestidas com filme DLC, HD2 e HD6, e da camisa referência montada no cilindro \#2 gerado, nas quatro posições angulares: 0, 90, 180 e $270^{\circ}$.

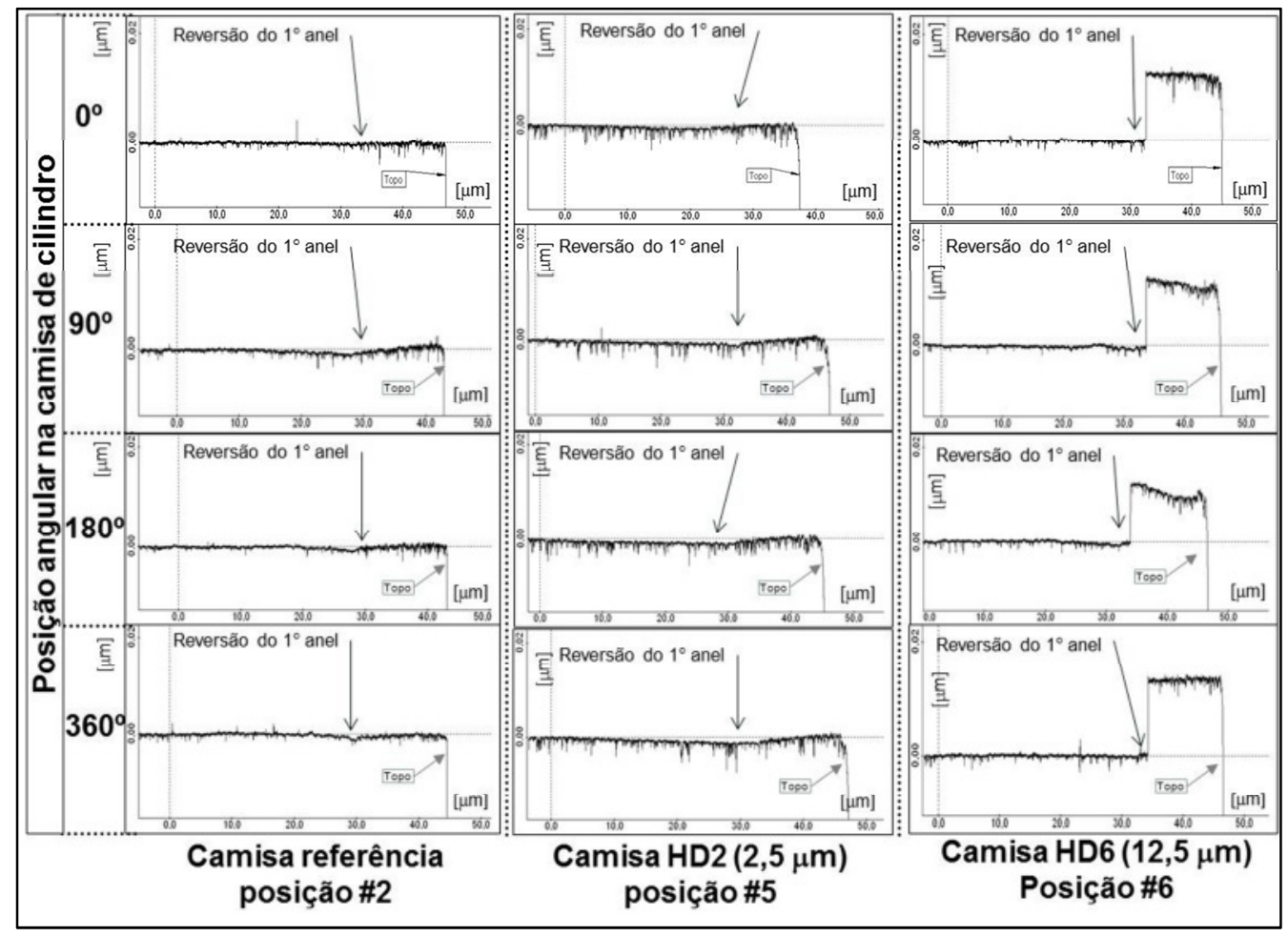

FIGURA 85 - Perfil de desgaste nas camisas HD após $10 \mathrm{~h}$ de rodagem no ciclo de amaciamento. 
Pelos valores de desgaste apresentados pela FIG. 85 nas regiões TDC, é possível verificar que o filme DLC presente na camisa HD6 foi completamente removido a partir do ponto de reversão do $1^{\circ}$ anel. A camisa HD2 não apresentou quaisquer evidências de desgaste acelerado e o seu aspecto foi similar ao observado nas camisas referência, que é representado na FIG. 85 pela camisa montada no cilindro \#2.

A camisa HD6 foi cortada ao meio para melhor visualização da superfície de trabalho que ficou sem o revestimento do filme DLC, e conforme mostra a FIG. 86, foi possível observar que a delaminação revelou o substrato de ferro fundido. Em uma das metades da camisa HD6, mediu-se o comprimento da delaminação onde se constatou um valor de aproximadamente $174 \mathrm{~mm}$. Este valor encontrado é facilmente correlacionado com o comprimento do curso que 0 pistão desenvolve adicionado da distância entre a primeira e a terceira canaleta do pistão. Desta forma, pode-se verificar que o filme DLC foi removido de toda a região em contato com os anéis de pistão, conforme ilustra a FIG. 86. Nas regiões onde não houve contato com os anéis de pistão, o filme DLC se manteve preservado sem nenhum sinal visível de degradação ou pontos de desgaste.

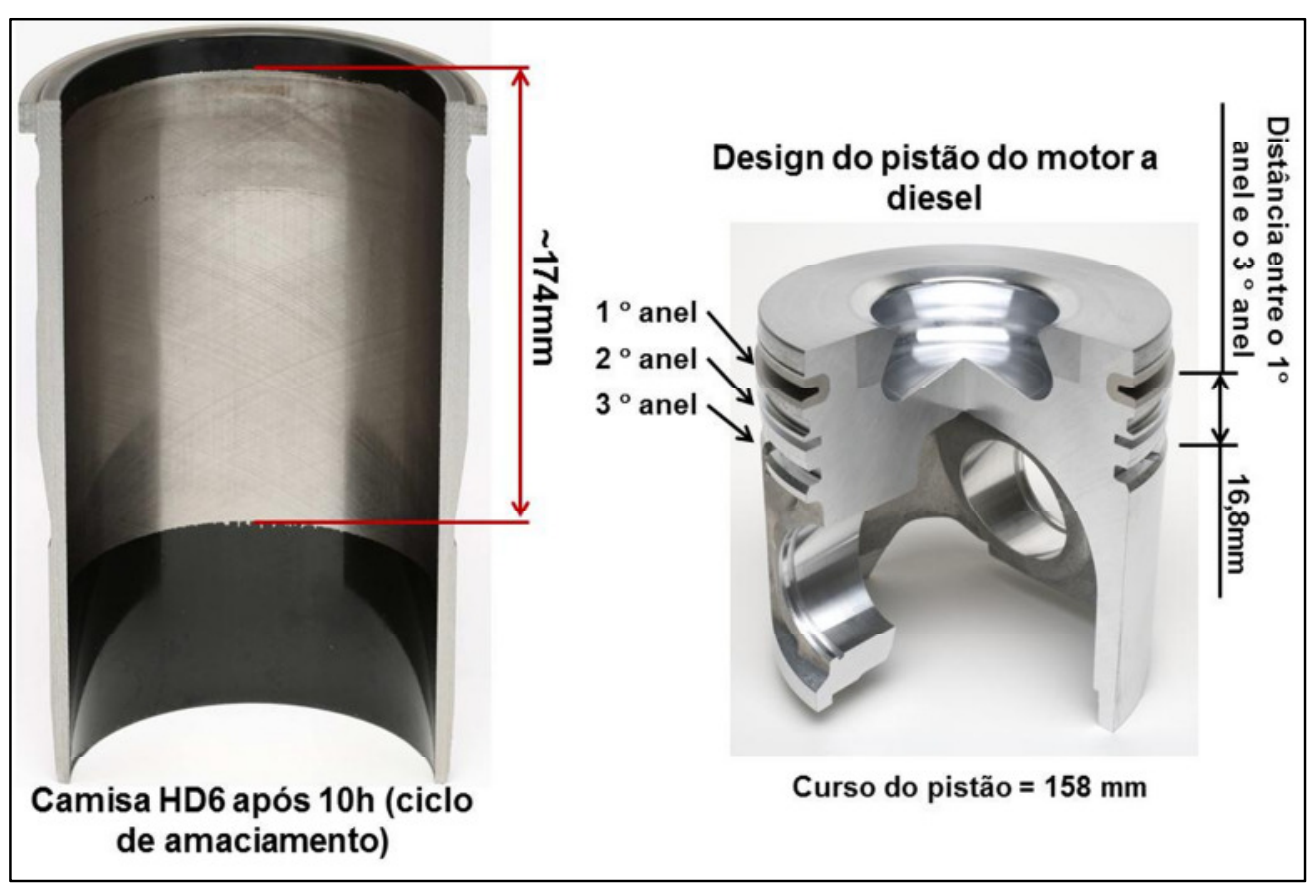

FIGURA 86 - Detalhe da camisa HD6 após ciclo de amaciamento mostrando delaminação do filme DLC na região de contato dos anéis de pistão. 
Ao fim das 500 horas do teste de durabilidade, todas as camisas HD foram retiradas do motor para inspeção visual, conforme mostra a FIG. 87. Os aspectos visuais das duas camisas referência selecionadas, montadas nos cilindros \#3 e \#4, são representativas para as demais camisas referência. A camisa HD2 não apresentou indicação de pontos de delaminação, inclusive com um aspecto mais limpo, em relação à presença de resíduos de carbono provenientes da queima do combustível, do que as camisas referência. Foi possível observar que o filme DLC da camisa HD2 se encontrava em condição preservada em toda a região de contato com os anéis de pistão. Em alguns pontos localizados na região TDC, o filme DLC ficou com uma coloração mais clara, sugerindo provável desgaste, com exposição do substrato. Entretanto, este fato não afetou o desempenho de motor durante as $500 \mathrm{~h}$.

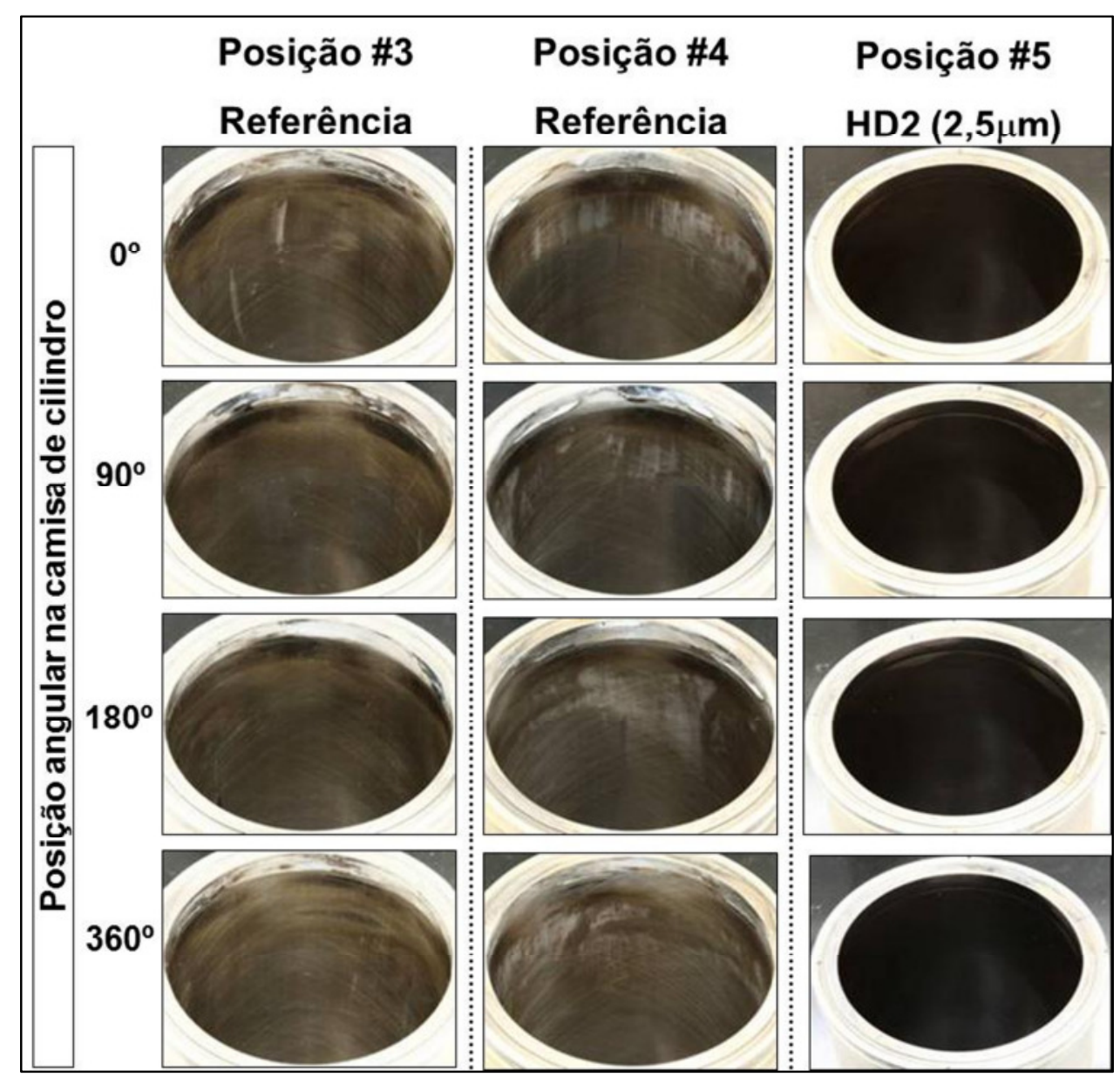

FIGURA 87 - Aspecto visual da camisa HD2 $(2,5 \mu \mathrm{m})$ e camisas referência após completarem $500 \mathrm{~h}$ de teste de rodagem em ciclo de durabilidade. 
O perfil de desgaste nas camisas HD seguiram os mesmos padrões adotados nas medições feitas após as primeiras 10 horas de amaciamento conforme ilustra a FIG. 88.

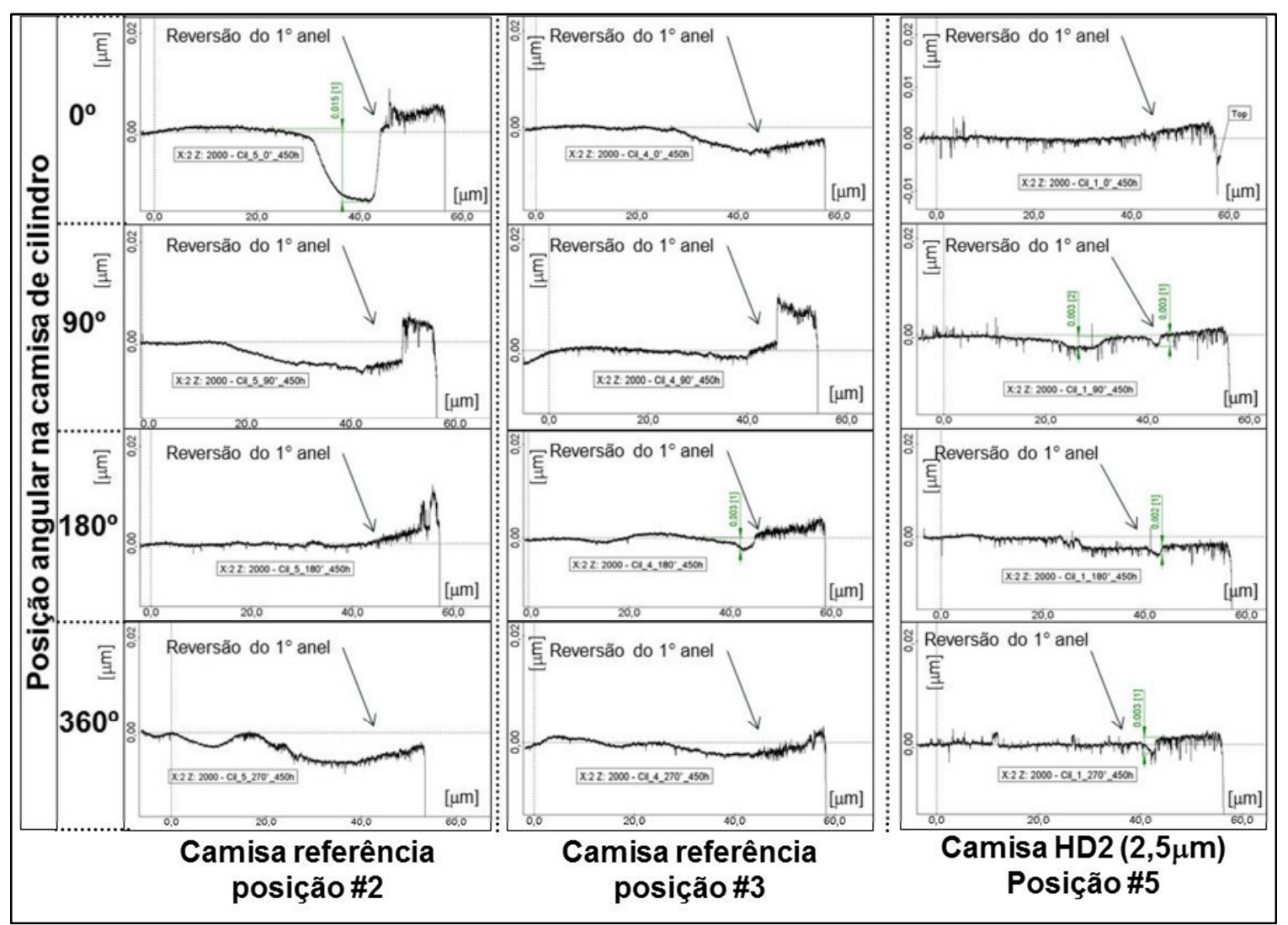

FIGURA 88 - Medição do desgaste das camisas HD após 500 h de teste de motor Diesel.

Com base nos resultados de traçagem 2D do perfil das camisas HD apresentados na FIG. 88 verificou-se que a camisa HD2 $(2,5 \mu \mathrm{m})$ apresentou menor desgaste, com um valor máximo de $5 \mu \mathrm{m}$, enquanto que as camisas referência apresentaram valores de até $15 \mu \mathrm{m}$. Desta forma, a camisa com filme DLC mais fino apresentou desempenho superior quando submetida ao contato com anéis de pistão revestidos com $\mathrm{CrN}$.

Com base nos resultados de bancada e nos testes de motor decidiu-se revestir novas camisas do tipo HD e FL com espessura de filme DLC de valor nominal de $2,5 \mu \mathrm{m}$. 


\subsection{Segunda Fase - Validação do conceito}

\subsubsection{Força de atrito em motor ciclo Otto com camisa flutuante}

Os valores de FMEP são apresentados na FIG. 89, onde para cada regime de operação do motor é possível verificar a influência da superfície de contato da camisa FL referência em relação camisa FL com filme DLC, uma vez que não houve alteração do projeto do pacote de anéis, do pistão e condição similar de montagem (folgas, condição de aperto do cabeçote).

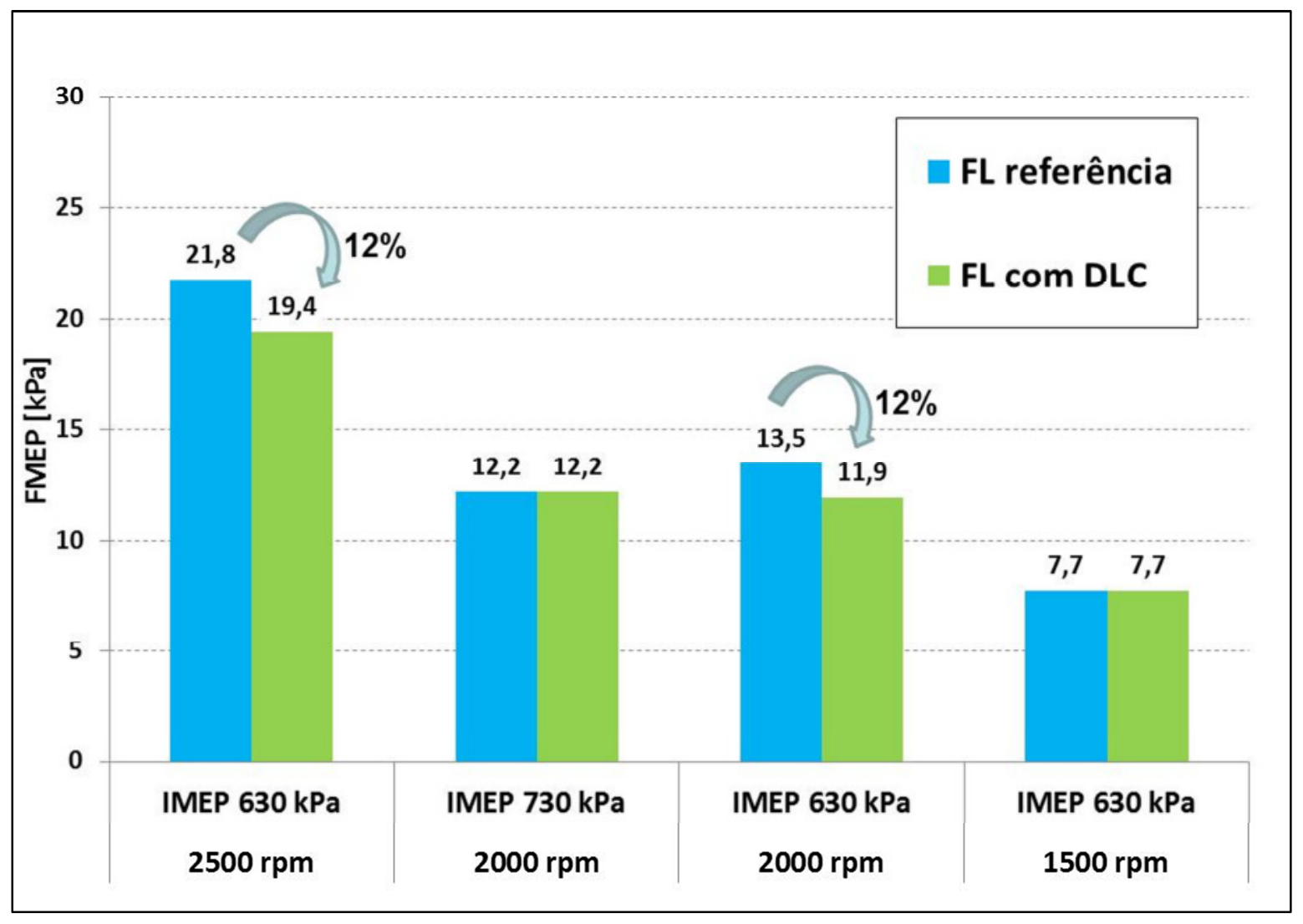

FIGURA 89 - Valores da pressão média de atrito (FMEP) nos regimes de operação do motor FLE.

Pela análise dos valores de FMEP, se observa uma redução de $12 \%$ no atrito nas condições de $2500 \mathrm{rpm}$ à $630 \mathrm{kPa}$ e $2000 \mathrm{rpm}$ à $630 \mathrm{kPa}$. Nos outros regimes de operação os resultados de FMEP foram semelhantes aos valores obtidos com a camisa referência, desempenho este não esperado pelo trabalho.

Os resultados de medição da rugosidade do brunimento a cada 5 horas de testes foram compilados em duas alturas a partir da face superior de topo, $10 \mathrm{e}$ 45 mm e estão apresentados nas FIG. 90 e 91. Pode-se observar que o efeito de 
quebra de picos da rugosidade esperado nas primeiras $15 \mathrm{~h}$ de duração do ciclo de amaciamento é mais evidente na camisa FL referência do que na camisa com filme DLC, pois logo nas primeiras 5 horas de teste se observa uma redução dos parâmetros Rpk e Rk. Provavelmente, devido à elevada dureza do filme DLC, não ocorreu a quebra dos picos da rugosidade e, tal fato pode ter contribuído para não haver redução dos valores de FMEP mais acentuados nas condições de operação do motor FLE, pois quanto maior é a rugosidade da superfície, maior é o atrito esperado (TOMANIK e FERRARESE, 2006).

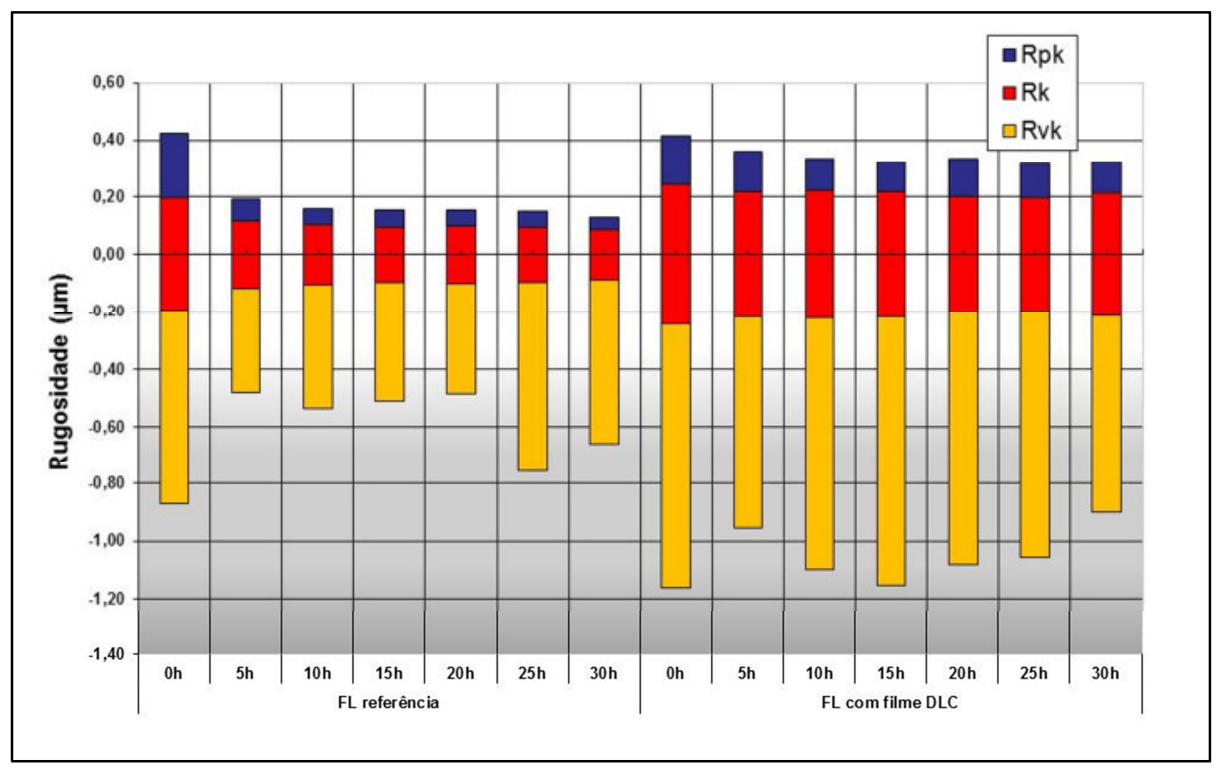

FIGURA 90 - Medição da rugosidade das camisas FL (10 mm do topo).

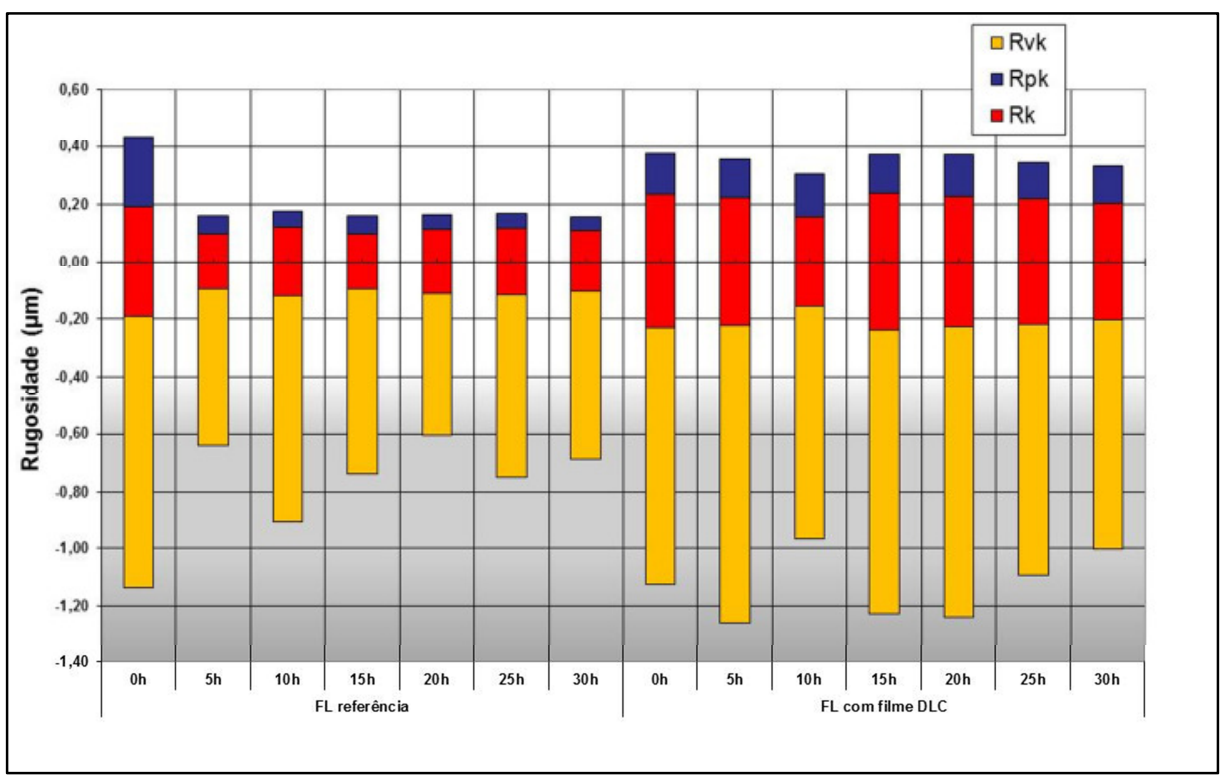

FIGURA 91 - Medição da rugosidade das camisas FL (45 mm de topo). 


\subsubsection{Teste de motor ciclo Diesel para medição do BSFC}

A FIG. 92 apresenta os resultados de desempenho do motor ciclo Diesel utilizado nesta etapa do trabalho após completar dois testes de rodagem de $125 \mathrm{~h}$ cada um em ciclo padrão de durabilidade, sendo o primeiro teste com um jogo de camisas HD referência e o segundo teste com um jogo de camisas HD revestidas com filme DLC $(2,5 \mu \mathrm{m}$ de espessura). O gráfico da FIG. 92 apresenta linhas cheias que estão relacionadas com o primeiro teste, feito com camisas HD referência, e linhas tracejadas relacionadas ao segundo teste, feito com camisas HD revestidas com filme DLC.

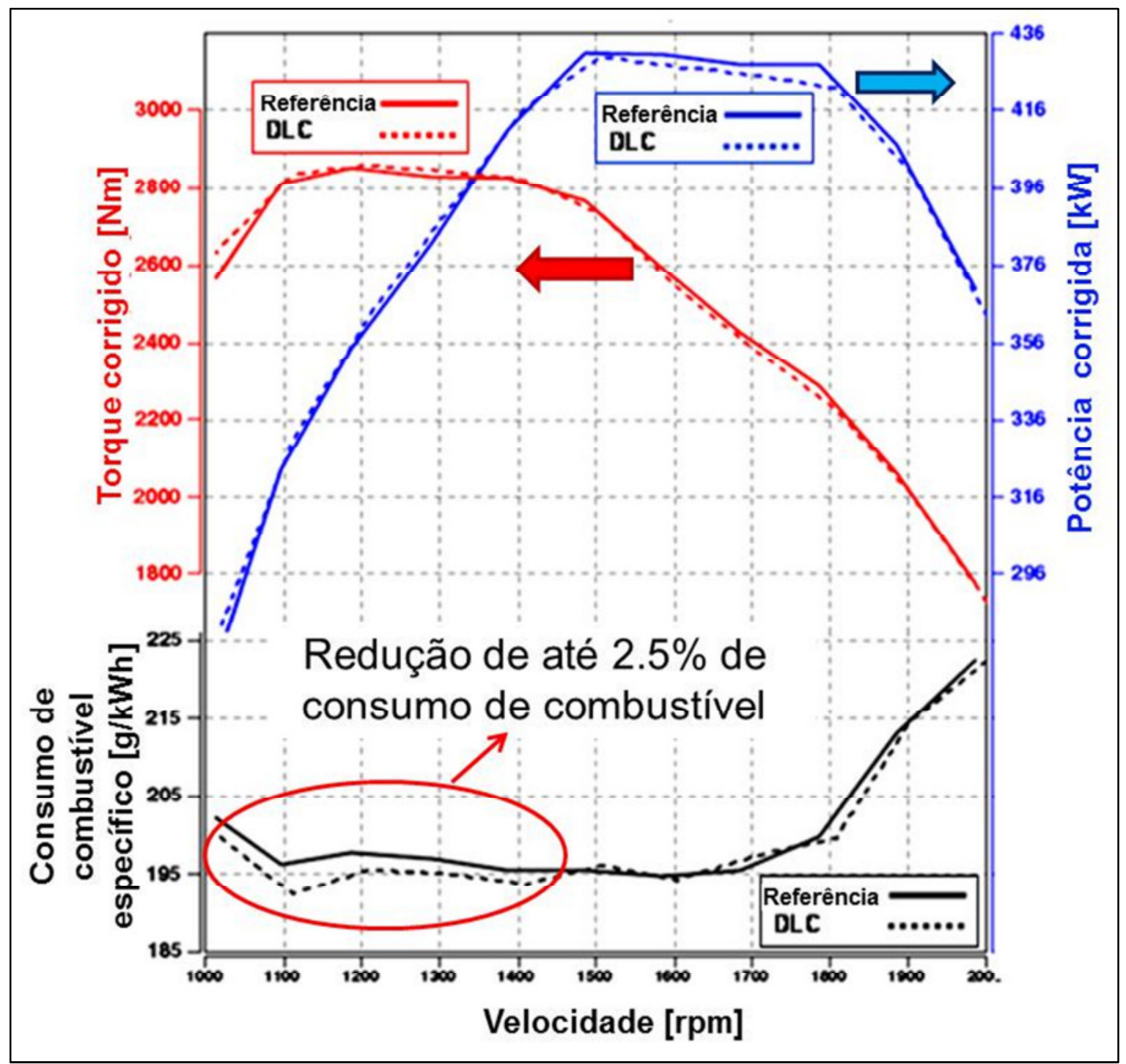

FIGURA 92 - Curva de desempenho do motor ciclo Diesel com camisas de referência e camisas com filme DLC na superfície interna. 
Com base nos resultados de potência e torque, percebe-se que o desempenho de ambos os motores Diesel foi similar, pois o desvio permitido para as características monitoradas foi de 1\%, conforme equipamento de medição utilizado. Entretanto, para o consumo específico de combustível (BSFC), onde a precisão de medição foi de $0,1 \%$, se observou uma queda dos valores durante o segundo teste em baixa velocidade, de 1000 a $1400 \mathrm{rpm}$. A redução do BSFC observada no segundo teste foi de até $2,5 \%$ em comparação com o primeiro, sendo que o motor tendeu a entregar maior potência nesta faixa de velocidade baixa. No restante da faixa de velocidade analisada não foram observadas vantagens na utilização das camisas HD revestidas com filme DLC, pois as curvas se mostraram estatisticamente similares.

Após o término do levantamento das curvas de desempenho de ambos os testes, as camisas HD e os respectivos jogos de anéis foram desmontados para análise do desgaste.

As análises do perfil de desgaste nas camisas seguiram o mesmo padrão dos testes de motor anteriores, com foco na região TDC e os respectivos anéis de primeiro canalete foram medidos na face de contato, por sobreposição do perfil de contato. Os perfis dos anéis foram traçados antes e após os testes de motor e o valor do desgaste foi calculado pelo valor linear do desalinhamento entre as curvas de perfil. A FIG. 93 ilustra o aspecto visual na região TDC de uma camisa HD revestida com filme DLC, montada no cilindro \#4, que representa 0 que ocorreu com as demais camisas revestidas, ilustrando as regiões de reversão dos três anéis de pistão. Medições representativas do desgaste na região TBD das camisas HD referência e das camisas HD revestidas com DLC foram inseridas na FIG. 96 ao lado da imagem da superfície da camisa com DLC buscando relacionar os valores de desgaste com os respectivos pontos de reversão dos anéis de pistão. Os resultados de desgaste mostram que as camisas HD referência apresentam maior desgaste na região de reversão do $1^{0}$ anel. O desgaste observado nos outros pontos de reversão foi semelhante para ambas às camisas HD. 


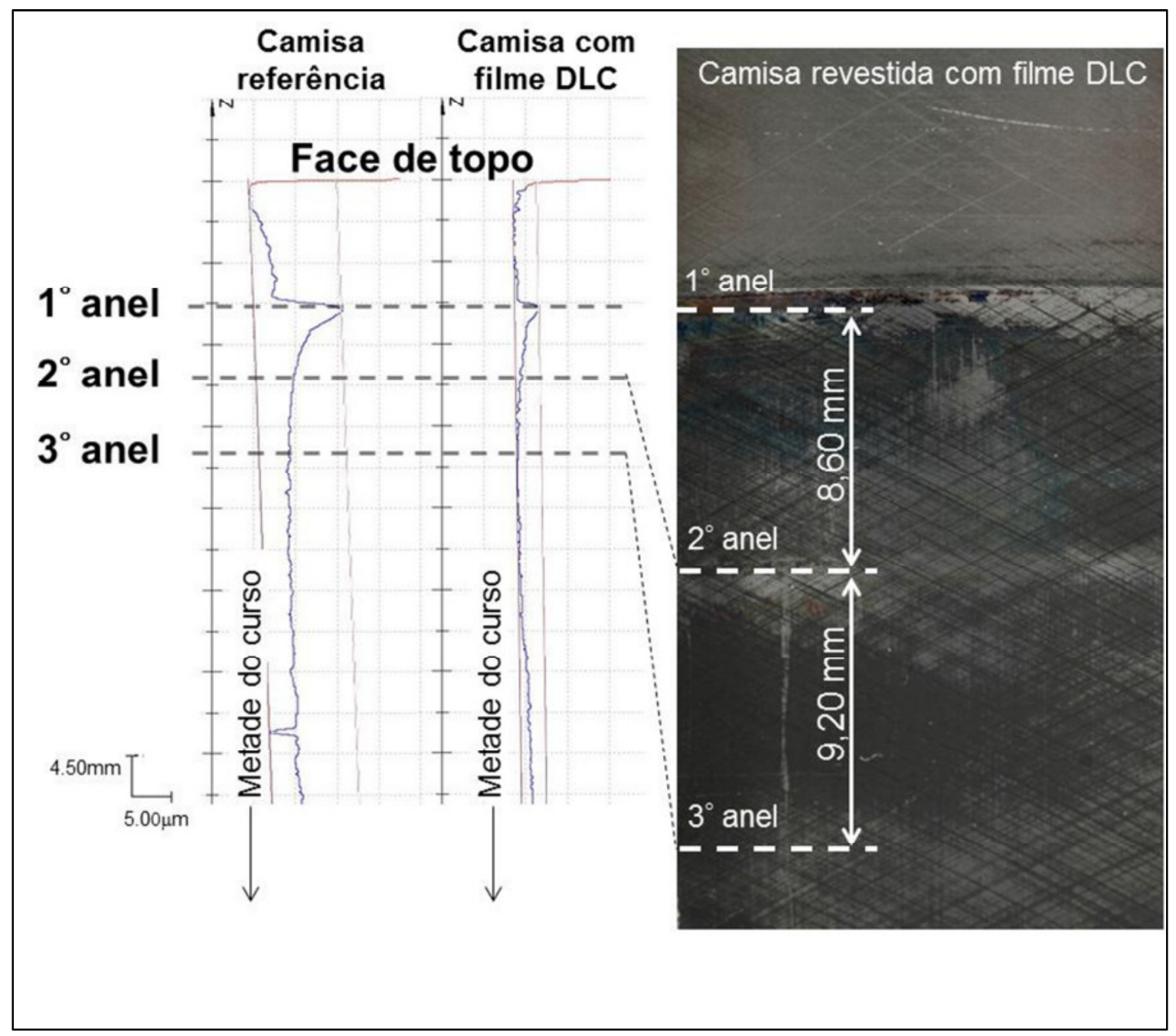

FIGURA 93 - Perfil de desgaste das camisas HD após $125 \mathrm{~h}$ de teste de motor ciclo Diesel e aspecto visual do filme DLC na região TDC.

Os resultados de desgaste nos anéis de pistão instalados no primeiro canalete são apresentados na FIG. 94, onde se calculou o valor médio com os respectivos desvios em cada variante de camisa HD. Os valores de desgaste medidos sugerem que os anéis de pistão que deslizaram sobre a superfície das camisas HD referência apresentaram maior desgaste na face de contato, inclusive com maior desvio quando comparado com os anéis que deslizaram contra a superfície das camisas HD recobertas com filme DLC. Os resultados de medição, tanto na camisa HD como nos anéis, sugerem que a durabilidade dos componentes foi favorecida com a utilização do filme DLC. 


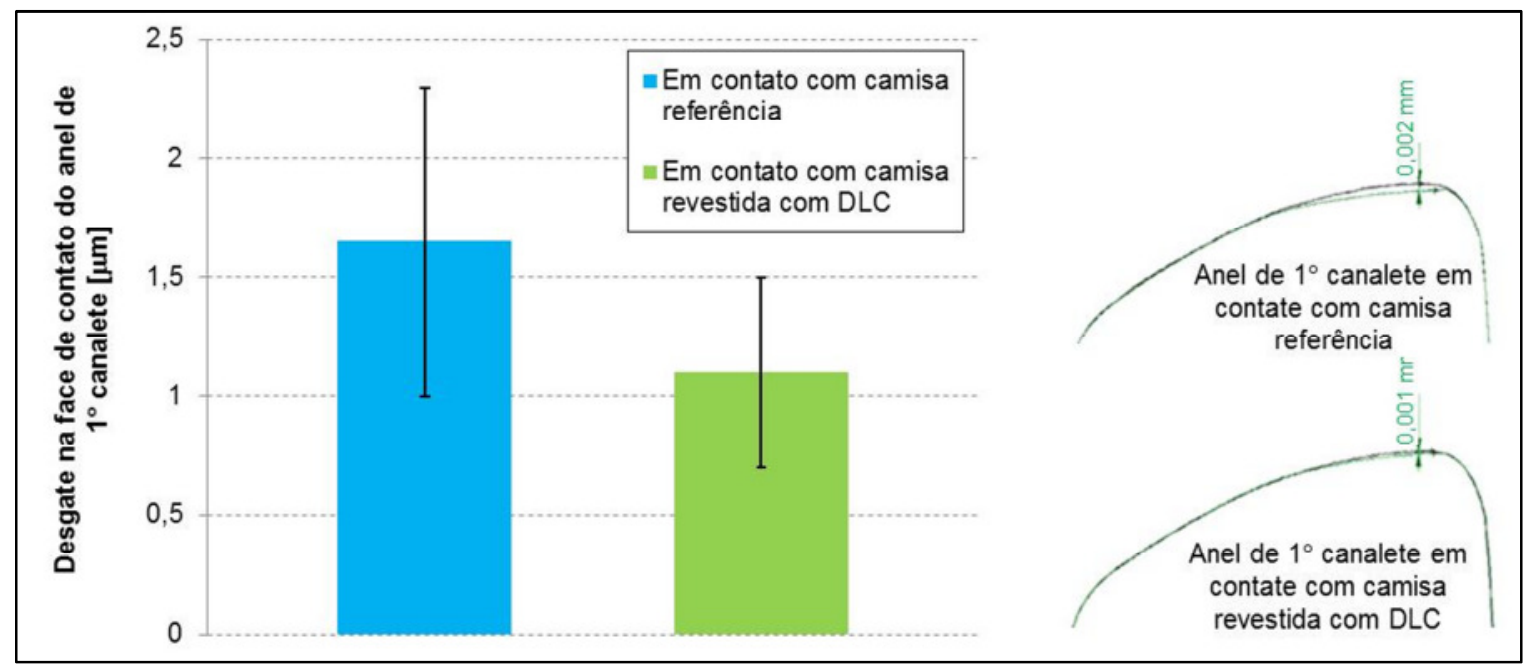

FIGURA 94 - Desgaste dos anéis de pistão após $125 \mathrm{~h}$ de teste de motor ciclo Diesel.

\subsubsection{Espectroscopia de espalhamento Raman no filme DLC após $125 \mathrm{~h}$ de rodagem em motor ciclo Diesel}

As análises por espectroscopia Raman foram conduzidas em corpos-de-prova recobertos com o filme $\operatorname{DLC}(2,5 \mu \mathrm{m})$, conforme descrito no item 4.10, FIG. 57.

A FIG. 95 apresenta os espectros obtidos em cada corpo-de-prova analisado. Os espectros dos filmes DLC depositados nas camisas HD novas, designados como CP1 e CP2, estão coerentes com o que se espera e são apresentados nas cores preta e vermelha para uma melhor visualização e análise comparativa. O espectro do CP5 na cor verde, que representa a região na camisa HD abaixo da área de trabalho dos anéis de pistão ou região inferior de reversão dos anéis, também conhecida como "bottom dead center" (BDC), apresentou comportamento similar ao observado para o CP2, sugerindo que o filme DLC localizado nesta região não sofreu alterações em suas porcentagens de ligações $\mathrm{sp}^{2} / \mathrm{sp}^{3}$. Os espectros das regiões expostas à alta temperatura de combustão, CP3 e CP4, nas cores verde oliva e violeta, apresentaram espectros Raman diferenciados dos demais. O espectro CP3 apresenta um aumento significativo da sua linha de base e de sua inclinação. O espectro Raman do CP4 apresenta uma linha de base totalmente diferente das demais e também de sua inclinação. 


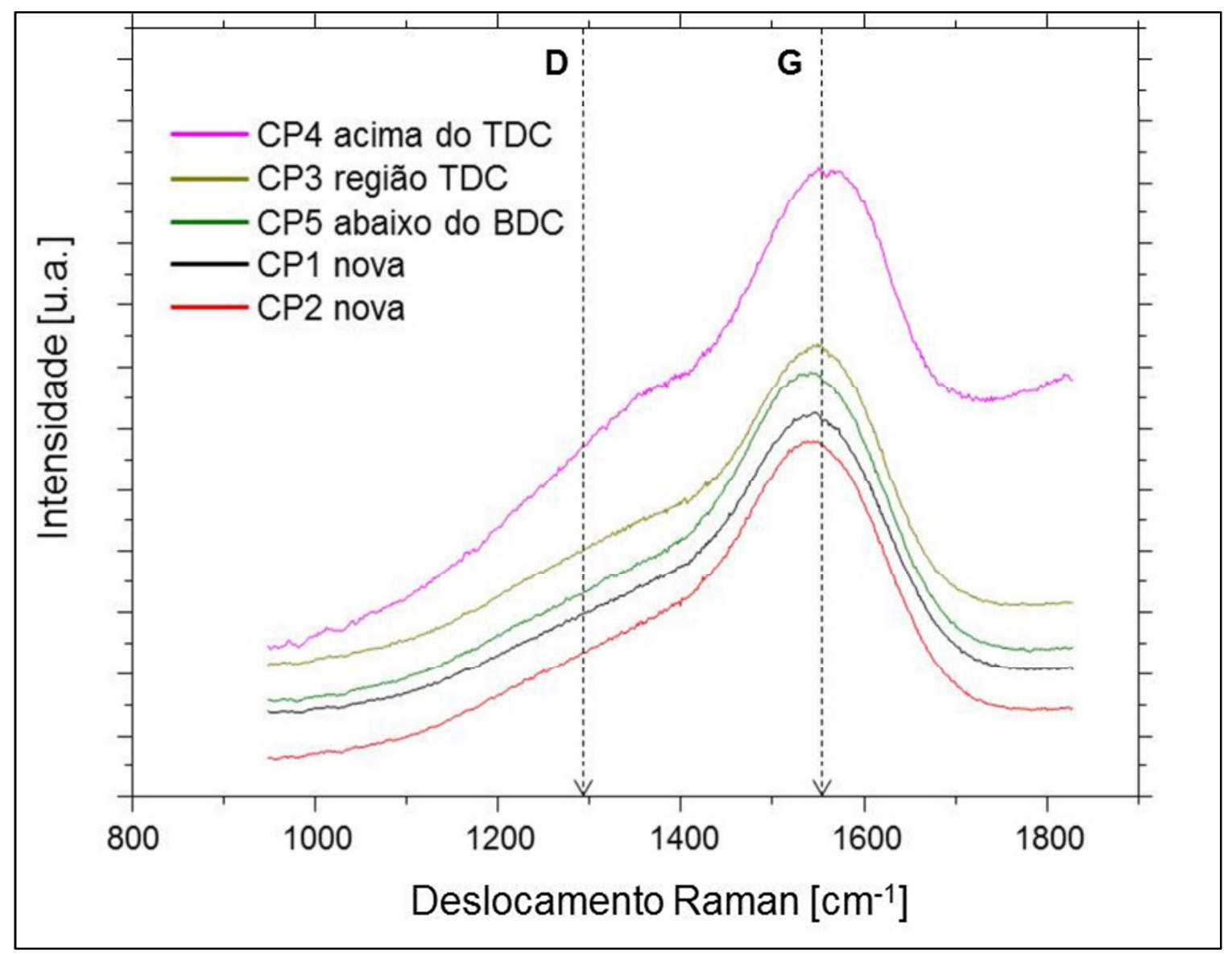

FIGURA 95 - Espectros Raman para os diferentes casos do filme DLC analisados.

A TAB. 26 resume todos os resultados das análises dos espectros apresentados na FIG. 95. Durante a análise foi feita a deconvolução das bandas $G$ e $D$, utilizando linhas gaussianas para ambas. Com isso foi determinada a posição central de cada banda (Centro), a largura de linha à meia altura (FWHM) e a intensidade integrada da banda (Área). A coluna ID/IG mostra a razão entre as intensidades integradas das bandas $D$ e $G$, respectivamente. Outro parâmetro importante determinado foi a inclinação da linha de base, referenciado como tg $\mathrm{A}$ (tangente do ângulo $A$ ), uma vez que a linha de base considerada foi uma reta com ângulo $A$ com o relação ao eixo horizontal.

Observam-se em todos os casos analisados bandas largas com picos centrados na região das bandas $D$ e $G$ do grafite, o que já era esperado devido ao alto grau de desordem cristalográfica, típicos de filmes carbonosos (DLC) amorfos (LOBO et al., 2005). Segundo ROBERTSON (1992), para todos os tipos de filmes 
a base de carbono com estrutura amorfa ou nanocristalina, o espectro Raman tipicamente apresenta o pico $\mathrm{G}$ centrado na banda $1550 \mathrm{~cm}^{-1}$ e o pico $D$ centrado na banda $1360 \mathrm{~cm}^{-1}$.

TABELA 26 - Resultados da análise dos espectros Raman

\begin{tabular}{cccccccccc}
\hline $\begin{array}{c}\text { Corpo } \\
\text { de }\end{array}$ & & Centro & Centro & FWHM & FWHM & Área G & Área D & ID/IG & tg A \\
prova & Ajuste & G $\left[\mathrm{cm}^{-1}\right]$ & D [cm $\left.{ }^{-1}\right]$ & G & D & & & & \\
\hline CP1 & Gauss & 1552,52 & 1377,86 & 168,43 & 321,29 & 327315 & 283153 & 0,87 & 0,41 \\
CP2 & Gauss & 1551,84 & 1377,08 & 167,37 & 320,41 & 342653 & 293925 & 0.86 & 0,45 \\
CP3 & Gauss & 1554,91 & 1384,84 & 153,25 & 328,96 & 295377 & 332362 & 1,13 & 0,56 \\
CP4 & Gauss & 1560,95 & 1381,52 & 150,86 & 289,83 & 330786 & 324785 & 0,98 & 2,52 \\
CP5 & Gauss & 1548,99 & 1369,36 & 168,85 & 318,60 & 365417 & 293954 & 0,80 & 0,50 \\
\hline
\end{tabular}

Os dados apresentados pela TAB. 26 sugerem que os desvios encontrados de espectro a espectro nos casos CP1, CP2 e CP5 são pouco significativos, que podem ser obtidos apenas devido a variações normais dos parâmetros de deposição do filme DLC. A amostra CP3 mostra um aumento da razão ID/IG, o que indica um pequeno aumento de sua grafitização, mas continua dentro de parâmetros adequados para um filme de DLC. Este aumento pode estar relacionado ao fato de que nesta região da camisa, acima do TDC, pode ter ocorrido um acumulo de resíduos da queima do combustível diesel à base de carbono. O espectro do CP4 apresenta um significativo aumento da linha de base e da sua inclinação impactando na coluna ( $\operatorname{tg} A$ ) que calcula a tangente da linha de base. Para filmes DLC depositados pelo processo CVD, a inclinação da linha de base é proporcional à concentração de hidrogênio incorporado no filme, ou seja, neste caso houve aumento de concentração da \% de \%H at., mas não se conseguiu encontrar correlação deste efeito com o desgaste do filme DLC sofrido nesta região da camisa HD. 


\section{CONCLUSÕES}

O processo de deposição PACVD suportado pela técnica HCPIIP utilizado no trabalho se mostrou bastante promissor quando aplicado em camisas de cilindro com superfície interna acabada, pelo fato de manter as características de rugosidade do substrato e não demandar operações de usinagem após deposição do filme DLC. Entretanto, se observou uma tendência de aumento do nível de distorção nas camisas de cilindro que demanda uma investigação adicional considerando um numero maior de peças a serem revestidas para avaliar a influência do manuseio e fixação durante o processo de deposição. Trata-se de um processo de deposição atrativo do ponto de vista de tempo de produção, pois possui taxa de deposição elevada e pode ser aplicado sobre uma superfície brunida, não demandando posteriores operações de acabamento.

A caracterização microestrutural via MEV/EDS foi capaz de identificar os elementos químicos necessários para julgar que ambos os filmes DLC estudados são filmes com gradiente de composição química entre os elementos Si e $C$ à medida que o filme cresce pelo processo PACVD. O resultado de dureza obtido pelos ensaios de nanoindentação para o filme DLC com espessura de 12,5 $\mu \mathrm{m}$ não atingiu valor conforme era esperado, que pode estar, segundo a literatura, ROBERTSON (1992), relacionado ao aumento da tensão superficial. Esta queda de dureza pode ter acarretado o insucesso do desempenho deste filme quando submetido a teste de durabilidade em motor ciclo Diesel, onde logo após as primeiras $10 \mathrm{~h}$ de rodagem, o filme foi completamente delaminado, revelando o substrato de ferro fundido da camisa HD6 na região de trabalho dos anéis de pistão. Por outro lado, o filme DLC com espessura de $2,5 \mu \mathrm{m}$ se mostrou promissor no mesmo teste de motor, apresentando um bom aspecto visual após completar $500 \mathrm{~h}$ de rodagem, reforçando uma recomendação de espessura mais fina.

Resultados de bancada recíproca confirmaram as vantagens que o filme DLC pode proporcionar na redução de atrito em 19\% quando comparado com as camisas referência sem revestimento. Este benefício foi reproduzido de forma parcial nos testes de motor ciclo Otto à gasolina com camisa FL revestidas, onde $\mathrm{o}$ atrito do motor, representado pela FMEP, foi menor em duas condições de operação. Por outro lado verificou-se que em função da elevada dureza do filme 
DLC, não ocorreu o efeito de amaciamento ou quebra dos picos, o que contribuiu para não reduzir o atrito como esperado. Esta observação suporta a sugestão de que camisas a serem revestidas com filme DLC devem apresentar um nível baixo rugosidade no substrato para reduzir o efeito da quebra dos picos de rugosidade.

A curva de desempenho levantada após o teste de durabilidade de 125 horas feita no motor Diesel confirmou que o filme DLC contribui efetivamente com a redução do consumo específico de combustível (BSFC), no teste observou-se uma redução de até $2,5 \%$, além de aumentar a durabilidade dos componentes por conta de apresentarem menor desgaste. Este resultado é de grande interesse, pois o motor com as seis camisas revestidas com filme DLC, além de consumir menos combustível na faixa de rotação baixa, apresentou tendência de maior potência também. Outras vantagens como emissão de gases poluentes podem servir de argumentação para futuros estudos, pois esta relacionada com a diminuição do consumo de combustível. Finalmente, com auxílio da espectroscopia Raman, foi possível melhor caracterizar o filme DLC com relação ao comportamento da razão entre as ligações $\mathrm{sp}^{2} / \mathrm{sp}^{3}$ que formam a sua estrutura. Alterações nesta razão foram observadas após o teste de motor ciclo Diesel na região TDC, alertando que o filme DLC se modificou devido ao fato do aumento da razão $\mathrm{sp}^{2} / \mathrm{sp}^{3}$. Este aumento pode estar relacionado ao fato de que nesta região da camisa, acima do TDC, pode ter ocorrido um acumulo de resíduos da queima do combustível diesel à base de carbono diferente do filme na condição inicial, sugerindo que houve grafitização, ou aumento da presença de carbono. Mesmo ocorrendo essas alterações no filme DLC, percebe-se que a proposta de projeto se manteve robusta e apresentou um menor desgaste dos componentes (anel de pistão - camisa de cilindro) após os testes propostos neste trabalho, o que sugere que o filme DLC tem grande potencial de sobreviver em condições mais severas de aplicação.

Desta forma, pode-se dizer que o uso do filme DLC em camisas de cilindro para motores à combustão interna favoreceu o desempenho do motor podendo ser uma alternativa aos projetos futuros que visam a redução do consumo de combustível para atendimento das futuras leis de emissão, assim como aumento da vida dos componentes na câmara de combustão, propiciando maiores intervalos para troca de peças. 


\section{APÊNDICE A - Circularidade das camisas HD}

\begin{tabular}{|c|c|c|c|c|c|c|c|c|c|c|c|c|c|}
\hline \multirow{2}{*}{$\begin{array}{l}\text { Altura } \\
\text { em } \\
\text { relação } \\
\text { ao Topo } \\
\text { [mm] }\end{array}$} & \multirow{2}{*}{$\begin{array}{c}\text { Valores de } \\
\text { projeto } \\
\text { para } \\
\text { camisa } \\
\text { HD }[\mu \mathrm{m}]\end{array}$} & \multicolumn{3}{|c|}{ Camisa HD1 } & \multicolumn{3}{|c|}{ Camisa HD2 } & \multicolumn{3}{|c|}{ Camisa HD4 } & \multicolumn{3}{|c|}{ Camisa HD6 } \\
\hline & & Antes & Depois & Diferença & Antes & Depois & Diferença & Antes & Depois & Diferença & Antes & Depois & Diferença \\
\hline 10 & \multirow{9}{*}{ 10,0 máx. } & 1,3 & 1,6 & 0,3 & 3,6 & 7,7 & 4,1 & 1,4 & 3,5 & 2,1 & 2,0 & 1,4 & $-0,6$ \\
\hline 30 & & 1,4 & 2,4 & 1,0 & 3,2 & 6,6 & 3,4 & 1,6 & 3,7 & 2,1 & 1,3 & 1,4 & 0,1 \\
\hline 50 & & 1,8 & 3,4 & 1,6 & 2,4 & 5,6 & 3,2 & 1,7 & 3,7 & 2,0 & 1,4 & 1,8 & 0,4 \\
\hline 90 & & 2,4 & 4,5 & 2,1 & 1,6 & 3,1 & 1,5 & 1,7 & 4,4 & 2,7 & 1,9 & 2,3 & 0,4 \\
\hline 110 & & 2,9 & 5,4 & 2,5 & 1,3 & 2,4 & 1,1 & 2,0 & 4,3 & 2,3 & 1,7 & 2,5 & 0,8 \\
\hline 130 & & 3,4 & 6,7 & 3,3 & 1,2 & 2,2 & 1,0 & 1,9 & 4,2 & 2,3 & 2,2 & 2,9 & 0,7 \\
\hline 150 & & 4,0 & 8,3 & 4,3 & 1,2 & 2,0 & 0,8 & 2,1 & 4,3 & 2,2 & 2,4 & 3,5 & 1,1 \\
\hline 170 & & 4,7 & 10,1 & 5,4 & 1,5 & 2,5 & 1,0 & 2,3 & 4,3 & 2,0 & 2,7 & 4,0 & 1,3 \\
\hline 190 & & 5,5 & 12,0 & 6,5 & 2,1 & 3,2 & 1,1 & 2,6 & 4,6 & 2,0 & 3,1 & 4,8 & 1,7 \\
\hline
\end{tabular}




\section{APÊNDICE B - Parâmetros de brunimento medidos na camisa HD1}

\begin{tabular}{|c|c|c|c|c|c|c|c|c|c|c|}
\hline \multirow{2}{*}{\multicolumn{2}{|c|}{$\begin{array}{l}\text { Camisa HD1 [Altura / } \\
\text { Posição angular] }\end{array}$}} & \multicolumn{9}{|c|}{ Parâmetros de rugosidade medidos } \\
\hline & & \multirow{2}{*}{$\frac{\mathrm{Ra}}{0,515}$} & \multirow{2}{*}{$\frac{\mathrm{Rz}}{4,16}$} & \multirow{2}{*}{$\frac{R \max }{6,68}$} & \multirow{2}{*}{$\frac{\mathrm{R} 3 \mathrm{z}}{2,86}$} & \multirow{2}{*}{$\frac{\text { Rpk }}{0,29}$} & \multirow{2}{*}{$\begin{array}{c}\mathrm{Rk} \\
0,79\end{array}$} & \multirow{2}{*}{$\frac{\text { Rvk }}{1,73}$} & \multirow{2}{*}{$\frac{\operatorname{Mr} 1(\%)}{7,1}$} & \multirow{2}{*}{$\frac{\mathrm{Mr} 2(\%)}{75}$} \\
\hline & Antes & & & & & & & & & \\
\hline \multirow[t]{3}{*}{$30 \mathrm{~mm} / 0^{\circ}$} & Depois & 0,637 & 4,71 & 6,64 & 3,10 & 0,25 & 0,99 & 2,04 & 5,8 & 73 \\
\hline & Diferença & 0,122 & 0,55 & $-0,04$ & 0,24 & $-0,04$ & 0,20 & 0,31 & $-1,3$ & -2 \\
\hline & Antes & 0,423 & 3,81 & 4,90 & 2,31 & 0,23 & 0,55 & 1,77 & 6,5 & 78 \\
\hline \multirow[t]{3}{*}{$30 \mathrm{~mm} / 90^{\circ}$} & Depois & 0,445 & 3,77 & 4,52 & 2,20 & 0,19 & 0,59 & 1,81 & 7,8 & 76 \\
\hline & Diferença & 0,022 & $-0,04$ & $-0,38$ & $-0,11$ & $-0,04$ & 0,04 & 0,04 & 1,3 & -2 \\
\hline & Antes & 0,468 & 4,39 & 4,94 & 2,79 & 0,14 & 0,62 & 1,83 & 5,8 & 76 \\
\hline \multirow[t]{3}{*}{$30 \mathrm{~mm} / 180^{\circ}$} & Depois & 0,459 & 3,80 & 5,03 & 2,25 & 0,19 & 0,62 & 1,70 & 6,3 & 75 \\
\hline & Diferença & $-0,009$ & $-0,59$ & 0,09 & $-0,54$ & 0,05 & 0,00 & $-0,13$ & 0,5 & -1 \\
\hline & Antes & 0,572 & 4,98 & 5,30 & 3,05 & 0,17 & 0,73 & 2,06 & 5,4 & 73 \\
\hline \multirow{2}{*}{$30 \mathrm{~mm} / 270^{\circ}$} & Depois & 0,580 & 5,16 & 6,63 & 2,42 & 0,27 & 0,84 & 2,14 & 8,5 & 75 \\
\hline & Diferença & 0,008 & 0,18 & 1,33 & $-0,63$ & 0,10 & 0,11 & 0,08 & 3,1 & 2 \\
\hline \multirow{3}{*}{$\begin{array}{c}\text { Média } \\
\text { calculada à } \\
\text { 30mm }\end{array}$} & Antes & 0,495 & 4,34 & 5,46 & 2,75 & 0,21 & 0,67 & 1,85 & 6,2 & 75,5 \\
\hline & Depois & 0,530 & 4,36 & 5,71 & 2,49 & 0,23 & 0,76 & 1,92 & 7,1 & 74,8 \\
\hline & Diferença & 0,036 & 0,03 & 0,25 & $-0,26$ & 0,02 & 0,09 & 0,07 & 0,9 & -1 \\
\hline \multirow{4}{*}{$90 \mathrm{~mm} / 0^{\circ}$} & Antes & 0,558 & 5,26 & 6,82 & 2,87 & 0,19 & 0,69 & 2,17 & 6,2 & 75 \\
\hline & Depois & 0,656 & 5,29 & 6,62 & 2,77 & 0,32 & 0,73 & 2,54 & 6,8 & 72 \\
\hline & Diferença & 0,098 & 0,03 & $-0,20$ & $-0,10$ & 0,13 & 0,04 & 0,37 & 0,6 & -3 \\
\hline & Antes & 0,432 & 4,59 & 6,43 & 2,59 & 0,14 & 0,62 & 1,58 & 5,1 & 75 \\
\hline \multirow[t]{3}{*}{$90 \mathrm{~mm} / 90^{\circ}$} & Depois & 0,544 & 3,88 & 5,41 & 2,76 & 0,17 & 0,68 & 1,86 & 5,5 & 72 \\
\hline & Diferença & 0,112 & $-0,71$ & $-1,02$ & 0,17 & 0,03 & 0,06 & 0,28 & 0,4 & -3 \\
\hline & Antes & 0,481 & 4,16 & 5,13 & 2,71 & 0,16 & 0,66 & 1,84 & 6,2 & 76 \\
\hline \multirow[t]{3}{*}{$90 \mathrm{~mm} / 180^{\circ}$} & Depois & 0,550 & 4,74 & 5,57 & 2,40 & 0,14 & 0,73 & 1,93 & 4,1 & 73 \\
\hline & Diferença & 0,069 & 0,58 & 0,44 & $-0,31$ & $-0,02$ & 0,07 & 0,09 & $-2,1$ & -3 \\
\hline & Antes & 0,571 & 4,92 & 5,75 & 2,71 & 0,17 & 0,75 & 1,84 & 5,7 & 71 \\
\hline \multirow[t]{2}{*}{$90 \mathrm{~mm} / 270^{\circ}$} & Depois & 0,661 & 5,11 & 5,68 & 3,16 & 0,15 & 1,01 & 1,91 & 4,3 & 69 \\
\hline & Diferença & 0,090 & 0,19 & $-0,07$ & 0,45 & $-0,02$ & 0,26 & 0,07 & $-1,4$ & -2 \\
\hline \multirow{3}{*}{$\begin{array}{c}\text { Média } \\
\text { calculada à } \\
90 \mathrm{~mm}\end{array}$} & Antes & 0,511 & 4,73 & 6,03 & 2,72 & 0,17 & 0,68 & 1,86 & 5,8 & 74,3 \\
\hline & Depois & 0,603 & 4,76 & 5,82 & 2,77 & 0,20 & 0,79 & 2,06 & 5,2 & 71,5 \\
\hline & Diferença & 0,092 & 0,02 & $-0,21$ & 0,05 & 0,03 & 0,11 & 0,20 & $-0,6$ & -3 \\
\hline
\end{tabular}




\section{APÊNDICE C - Parâmetros de brunimento medidos na camisa HD2}

\begin{tabular}{|c|c|c|c|c|c|c|c|c|c|c|}
\hline \multirow{2}{*}{\multicolumn{2}{|c|}{$\begin{array}{c}\text { Camisa HD2 [Altura / } \\
\text { Posição angular] }\end{array}$}} & \multicolumn{9}{|c|}{ Parâmetros de rugosidade medidos } \\
\hline & & $\mathrm{Ra}$ & $\mathrm{Rz}$ & Rmax & $\mathrm{R} 3 z$ & Rpk & Rk & Rvk & Mr1 (\%) & $\operatorname{Mr} 2(\%)$ \\
\hline \multirow{3}{*}{$30 \mathrm{~mm} / 0^{\circ}$} & Antes & 0,602 & 4,58 & 5,77 & 3,02 & 0,35 & 0,76 & 2,26 & 7,7 & 73 \\
\hline & Depois & 0,707 & 4,97 & 6,54 & 2,66 & 0,25 & 1,00 & 2,26 & 5,0 & 70 \\
\hline & Diferença & 0,105 & 0,39 & 0,77 & $-0,36$ & $-0,10$ & 0,24 & 0,00 & $-2,7$ & -3 \\
\hline \multirow{3}{*}{$30 \mathrm{~mm} / 90^{\circ}$} & Antes & 0,453 & 4,70 & 7,80 & 2,27 & 0,16 & 0,63 & 1,79 & 5,9 & 76 \\
\hline & Depois & 0,571 & 4,18 & 6,07 & 2,26 & 0,18 & 0,78 & 2,01 & 4,8 & 73 \\
\hline & Diferença & 0,118 & $-0,52$ & $-1,73$ & $-0,01$ & 0,02 & 0,15 & 0,22 & $-1,1$ & -3 \\
\hline \multirow{3}{*}{$30 \mathrm{~mm} / 180^{\circ}$} & Antes & 0,438 & 5,24 & 6,58 & 2,47 & 0,15 & 0,62 & 1,78 & 5,2 & 77 \\
\hline & Depois & 0,590 & 4,67 & 5,88 & 2,86 & 0,26 & 0,71 & 2,14 & 6,4 & 73 \\
\hline & Diferença & 0,152 & $-0,57$ & $-0,70$ & 0,39 & 0,11 & 0,09 & 0,36 & 1,2 & -4 \\
\hline \multirow{3}{*}{$30 \mathrm{~mm} / 270^{\circ}$} & Antes & 0,391 & 4,11 & 6,15 & 2,49 & 0,16 & 0,61 & 1,62 & 5,1 & 79 \\
\hline & Depois & 0,427 & 3,89 & 5,67 & 2,16 & 0,15 & 0,58 & 1,61 & 6,3 & 76 \\
\hline & Diferença & 0,036 & $-0,22$ & $-0,48$ & $-0,33$ & $-0,01$ & $-0,03$ & $-0,01$ & 1,2 & -3 \\
\hline \multirow{3}{*}{$\begin{array}{l}\text { Média } \\
\text { calculada à } \\
\text { 30mm }\end{array}$} & Antes & 0,471 & 4,66 & 6,58 & 2,56 & 0,21 & 0,66 & 1,86 & 6,0 & 76,3 \\
\hline & Depois & 0,574 & 4,43 & 6,04 & 2,49 & 0,21 & 0,77 & 2,01 & 5,6 & 73,0 \\
\hline & Diferença & 0,103 & $-0,23$ & $-0,54$ & $-0,08$ & 0,00 & 0,11 & 0,14 & $-0,3$ & -3 \\
\hline \multirow{3}{*}{$90 \mathrm{~mm} / 0^{\circ}$} & Antes & 0,418 & 4,42 & 6,39 & 2,14 & 0,14 & 0,59 & 1,63 & 6,6 & 76 \\
\hline & Depois & 0,566 & 4,80 & 6,63 & 2,54 & 0,31 & 0,87 & 2,01 & 6,0 & 75 \\
\hline & Diferença & 0,148 & 0,38 & 0,24 & 0,40 & 0,17 & 0,28 & 0,38 & $-0,6$ & -1 \\
\hline \multirow{3}{*}{$90 \mathrm{~mm} / 90^{\circ}$} & Antes & 0,632 & 5,13 & 6,37 & 3,17 & 0,18 & 0,82 & 2,22 & 5,1 & 72 \\
\hline & Depois & 0,683 & 4,84 & 6,00 & 2,94 & 0,33 & 0,97 & 2,30 & 5,7 & 71 \\
\hline & Diferença & 0,051 & $-0,29$ & $-0,37$ & $-0,23$ & 0,15 & 0,15 & 0,08 & 0,6 & -1 \\
\hline \multirow{3}{*}{$90 \mathrm{~mm} / 180^{\circ}$} & Antes & 0,549 & 5,29 & 7,92 & 2,97 & 0,24 & 0,62 & 2,36 & 7,1 & 76 \\
\hline & Depois & 0,567 & 3,96 & 5,28 & 2,75 & 0,21 & 0,79 & 2,03 & 6,2 & 74 \\
\hline & Diferença & 0,018 & $-1,33$ & $-2,64$ & $-0,22$ & $-0,03$ & 0,17 & $-0,33$ & $-0,9$ & -2 \\
\hline \multirow{3}{*}{$90 \mathrm{~mm} / 270^{\circ}$} & Antes & 0,473 & 4,12 & 5,89 & 2,84 & 0,18 & 0,57 & 1,87 & 6,2 & 76 \\
\hline & Depois & 0,702 & 4,93 & 5,79 & 2,70 & 0,14 & 0,90 & 2,23 & 4,4 & 69 \\
\hline & Diferença & 0,229 & 0,81 & $-0,10$ & $-0,14$ & $-0,04$ & 0,33 & 0,36 & $-1,8$ & -7 \\
\hline \multirow{3}{*}{$\begin{array}{c}\text { Média } \\
\text { calculada à } \\
\text { 90mm }\end{array}$} & Antes & 0,518 & 4,74 & 6,64 & 2,78 & 0,19 & 0,65 & 2,02 & 6,3 & 75,0 \\
\hline & Depois & 0,630 & 4,63 & 5,93 & 2,73 & 0,25 & 0,88 & 2,14 & 5,6 & 72,3 \\
\hline & Diferença & 0,112 & $-0,11$ & $-0,72$ & $-0,05$ & 0,06 & 0,23 & 0,12 & $-0,7$ & -3 \\
\hline
\end{tabular}




\section{APÊNDICE D - Parâmetros de brunimento medidos na camisa HD4}

\begin{tabular}{|c|c|c|c|c|c|c|c|c|c|c|}
\hline \multirow{2}{*}{\multicolumn{2}{|c|}{$\begin{array}{l}\text { Camisa HD4 [Altura / } \\
\text { Posição angular] }\end{array}$}} & \multicolumn{9}{|c|}{ Parâmetros de rugosidade medidos } \\
\hline & & $\mathrm{Ra}$ & $\mathrm{Rz}$ & $R \max$ & $\mathrm{R} 3 z$ & Rpk & $\mathrm{Rk}$ & Rvk & Mr1 (\%) & $\operatorname{Mr} 2(\%)$ \\
\hline \multirow{3}{*}{$30 \mathrm{~mm} / 0^{\circ}$} & Antes & 0,443 & 4,52 & 5,60 & 2,40 & 0,16 & 0,55 & 2,04 & 7,1 & 79 \\
\hline & Depois & 0,509 & 4,80 & 5,64 & 2,20 & 0,13 & 0,67 & 2,27 & 5,3 & 78 \\
\hline & Diferença & 0,066 & 0,28 & 0,04 & $-0,20$ & $-0,03$ & 0,12 & 0,23 & $-1,8$ & -1 \\
\hline \multirow{3}{*}{$30 \mathrm{~mm} / 90^{\circ}$} & Antes & 0,616 & 5,21 & 6,38 & 3,33 & 0,17 & 0,82 & 2,23 & 5,9 & 73 \\
\hline & Depois & 0,590 & 4,59 & 6,50 & 2,82 & 0,22 & 1,03 & 1,82 & 6,1 & 74 \\
\hline & Diferença & $-0,026$ & $-0,62$ & 0,12 & $-0,51$ & 0,05 & 0,21 & $-0,41$ & 0,2 & 1 \\
\hline \multirow{3}{*}{$30 \mathrm{~mm} / 180^{\circ}$} & Antes & 0,464 & 4,62 & 5,45 & 2,85 & 0,23 & 0,61 & 1,87 & 7,3 & 76 \\
\hline & Depois & 0,649 & 5,03 & 6,24 & 2,87 & 0,22 & 0,88 & 2,50 & 6,8 & 74 \\
\hline & Diferença & 0,185 & 0,41 & 0,79 & 0,02 & $-0,01$ & 0,27 & 0,63 & $-0,5$ & -2 \\
\hline \multirow{3}{*}{$30 \mathrm{~mm} / 270^{\circ}$} & Antes & 0,690 & 5,59 & 7,63 & 3,17 & 0,17 & 0,66 & 2,68 & 6,6 & 72 \\
\hline & Depois & 0,529 & 3,88 & 4,95 & 2,35 & 0,20 & 0,77 & 1,68 & 6,5 & 71 \\
\hline & Diferença & $-0,161$ & $-1,71$ & $-2,68$ & $-0,82$ & 0,03 & 0,11 & $-1,00$ & $-0,1$ & -1 \\
\hline \multirow{3}{*}{$\begin{array}{c}\text { Média } \\
\text { calculada à } \\
30 \mathrm{~mm} \\
\end{array}$} & Antes & 0,553 & 4,99 & 6,27 & 2,94 & 0,18 & 0,66 & 2,21 & 6,7 & 75,0 \\
\hline & Depois & 0,569 & 4,58 & 5,83 & 2,56 & 0,19 & 0,84 & 2,07 & 6,2 & 74,3 \\
\hline & Diferença & 0,016 & $-0,41$ & $-0,43$ & $-0,38$ & 0,01 & 0,18 & $-0,14$ & $-0,6$ & -1 \\
\hline \multirow{3}{*}{$90 \mathrm{~mm} / 0^{\circ}$} & Antes & 0,705 & 4,78 & 6,58 & 3,44 & 0,19 & 0,94 & 2,29 & 4,6 & 71 \\
\hline & Depois & 0,672 & 4,79 & 6,56 & 2,77 & 0,37 & 1,42 & 1,80 & 4,5 & 75 \\
\hline & Diferença & $-0,033$ & 0,01 & $-0,02$ & $-0,67$ & 0,18 & 0,48 & $-0,49$ & $-0,1$ & 4 \\
\hline \multirow{3}{*}{$90 \mathrm{~mm} / 90^{\circ}$} & Antes & 0,532 & 4,70 & 5,89 & 3,15 & 0,21 & 0,73 & 2,02 & 5,7 & 76 \\
\hline & Depois & 0,672 & 5,62 & 7,38 & 2,79 & 0,27 & 0,86 & 2,30 & 6,0 & 71 \\
\hline & Diferença & 0,140 & 0,92 & 1,49 & $-0,36$ & 0,06 & 0,13 & 0,28 & 0,3 & -5 \\
\hline \multirow{3}{*}{$90 \mathrm{~mm} / 180^{\circ}$} & Antes & 0,665 & 4,68 & 6,52 & 3,20 & 0,13 & 0,91 & 2,33 & 5,0 & 71 \\
\hline & Depois & 0,727 & 5,20 & 6,83 & 2,96 & 0,19 & 1,28 & 2,19 & 4,6 & 74 \\
\hline & Diferença & 0,062 & 0,52 & 0,31 & $-0,24$ & 0,06 & 0,37 & $-0,14$ & $-0,4$ & 3 \\
\hline \multirow{3}{*}{$90 \mathrm{~mm} / 270^{\circ}$} & Antes & 0,510 & 4,48 & 7,05 & 2,80 & 0,20 & 0,82 & 1,96 & 5,8 & 76 \\
\hline & Depois & 0,611 & 4,65 & 7,12 & 2,69 & 0,25 & 1,09 & 2,20 & 8,1 & 78 \\
\hline & Diferença & 0,101 & 0,17 & 0,07 & $-0,11$ & 0,05 & 0,27 & 0,24 & 2,3 & 2 \\
\hline \multirow{3}{*}{$\begin{array}{c}\text { Média } \\
\text { calculada à } \\
90 \mathrm{~mm}\end{array}$} & Antes & 0,603 & 4,66 & 6,51 & 3,15 & 0,18 & 0,85 & 2,15 & 5,3 & 73,5 \\
\hline & Depois & 0,671 & 5,07 & 6,97 & 2,80 & 0,27 & 1,16 & 2,12 & 5,8 & 74,5 \\
\hline & Diferença & 0,068 & 0,40 & 0,46 & $-0,35$ & 0,09 & 0,31 & $-0,03$ & 0,5 & 1 \\
\hline
\end{tabular}




\section{APÊNDICE E - Parâmetros de brunimento medidos na camisa HD6}

\begin{tabular}{|c|c|c|c|c|c|c|c|c|c|c|}
\hline \multirow{2}{*}{\multicolumn{2}{|c|}{$\begin{array}{l}\text { Camisa HD6 [Altura / } \\
\text { Posição angular] }\end{array}$}} & \multicolumn{9}{|c|}{ Parâmetros de rugosidade medidos } \\
\hline & & $\mathrm{Ra}$ & $\mathrm{Rz}$ & $R \max$ & $\mathrm{R} 3 z$ & Rpk & Rk & Rvk & Mr1 (\%) & $\operatorname{Mr} 2(\%)$ \\
\hline \multirow{3}{*}{$30 \mathrm{~mm} / 0^{\circ}$} & Antes & 0,420 & 3,45 & 3,93 & 2,23 & 0,23 & 0,57 & 1,73 & 7,1 & 77 \\
\hline & Depois & 0,418 & 3,38 & 4,65 & 1,84 & 0,18 & 0,69 & 1,42 & 5,4 & 75 \\
\hline & Diferença & $-0,002$ & $-0,07$ & 0,72 & $-0,39$ & $-0,05$ & 0,12 & $-0,31$ & $-1,7$ & -2 \\
\hline \multirow{3}{*}{$30 \mathrm{~mm} / 90^{\circ}$} & Antes & 0,327 & 4,06 & 5,46 & 1,98 & 0,17 & 0,50 & 1,35 & 8,1 & 79 \\
\hline & Depois & 0,451 & 4,11 & 5,59 & 2,08 & 0,38 & 0,76 & 1,45 & 6,0 & 76 \\
\hline & Diferença & 0,124 & 0,05 & 0,13 & 0,10 & 0,21 & 0,26 & 0,10 & $-2,1$ & -3 \\
\hline \multirow{3}{*}{$30 \mathrm{~mm} / 180^{\circ}$} & Antes & 0,395 & 3,24 & 3,98 & 1,89 & 0,13 & 0,62 & 1,29 & 4,7 & 74 \\
\hline & Depois & 0,406 & 3,34 & 4,02 & 2,09 & 0,15 & 0,69 & 1,30 & 4,7 & 2 \\
\hline & Diferença & 0,011 & 0,10 & 0,04 & 0,20 & 0,02 & 0,07 & 0,01 & 0,0 & -72 \\
\hline \multirow{3}{*}{$30 \mathrm{~mm} / 270^{\circ}$} & Antes & 0,499 & 3,68 & 4,67 & 2,34 & 0,23 & 0,57 & 1,93 & 5,4 & 74 \\
\hline & Depois & 0,488 & 3,50 & 4,52 & 2,43 & 0,26 & 0,74 & 1,63 & 5,5 & 74 \\
\hline & Diferença & $-0,011$ & $-0,18$ & $-0,15$ & 0,09 & 0,03 & 0,17 & $-0,30$ & 0,1 & 0 \\
\hline \multirow{3}{*}{$\begin{array}{c}\text { Média } \\
\text { calculada à } \\
\text { 30mm } \\
\end{array}$} & Antes & 0,410 & 3,61 & 4,51 & 2,11 & 0,19 & 0,57 & 1,58 & 6,3 & 76,0 \\
\hline & Depois & 0,441 & 3,58 & 4,70 & 2,11 & 0,24 & 0,72 & 1,45 & 5,4 & 56,8 \\
\hline & Diferença & 0,031 & $-0,02$ & 0,19 & 0,00 & 0,05 & 0,16 & $-0,13$ & $-0,9$ & -19 \\
\hline \multirow{3}{*}{$90 \mathrm{~mm} / 0^{\circ}$} & Antes & 0,564 & 4,02 & 5,20 & 2,45 & 0,13 & 0,71 & 1,97 & 5,4 & 72 \\
\hline & Depois & 0,444 & 3,87 & 4,50 & 2,17 & 0,22 & 0,78 & 1,26 & 5,2 & 73 \\
\hline & Diferença & $-0,120$ & $-0,15$ & $-0,70$ & $-0,28$ & 0,09 & 0,07 & $-0,71$ & $-0,2$ & 1 \\
\hline \multirow{3}{*}{$90 \mathrm{~mm} / 90^{\circ}$} & Antes & 0,493 & 3,56 & 4,05 & 2,45 & 0,13 & 0,68 & 1,61 & 4,4 & 71 \\
\hline & Depois & 0,471 & 3,40 & 4,16 & 2,28 & 0,16 & 0,78 & 1,40 & 3,4 & 72 \\
\hline & Diferença & $-0,022$ & $-0,16$ & 0,11 & $-0,17$ & 0,03 & 0,10 & $-0,21$ & $-1,0$ & 1 \\
\hline \multirow{3}{*}{$90 \mathrm{~mm} / 180^{\circ}$} & Antes & 0,480 & 3,96 & 5,03 & 2,87 & 0,12 & 0,92 & 1,42 & 3,6 & 71 \\
\hline & Depois & 0,593 & 4,12 & 5,21 & 2,62 & 0,19 & 1,24 & 1,77 & 3,9 & 77 \\
\hline & Diferença & 0,113 & 0,16 & 0,18 & $-0,25$ & 0,07 & 0,32 & 0,35 & 0,3 & 6 \\
\hline \multirow{3}{*}{$90 \mathrm{~mm} / 270^{\circ}$} & Antes & 0,597 & 4,25 & 4,67 & 1,98 & 0,13 & 0,98 & 1,70 & 3,7 & 71 \\
\hline & Depois & 0,644 & 4,47 & 5,45 & 2,96 & 0,32 & 1,22 & 1,81 & 7,1 & 74 \\
\hline & Diferença & 0,047 & 0,22 & 0,78 & 0,98 & 0,19 & 0,24 & 0,11 & 3,4 & 3 \\
\hline \multirow{3}{*}{$\begin{array}{c}\text { Média } \\
\text { calculada à } \\
90 \mathrm{~mm}\end{array}$} & Antes & 0,534 & 3,95 & 4,74 & 2,44 & 0,13 & 0,82 & 1,68 & 4,3 & 71,3 \\
\hline & Depois & 0,538 & 3,97 & 4,83 & 2,51 & 0,22 & 1,01 & 1,56 & 4,9 & 74,0 \\
\hline & Diferença & 0,005 & 0,02 & 0,09 & 0,07 & 0,10 & 0,18 & $-0,12$ & 0,6 & 3 \\
\hline
\end{tabular}




\section{APÊNDICE F - Resumos dos valores de COF a $120^{\circ} \mathrm{C}(0 \mathrm{~h})$}

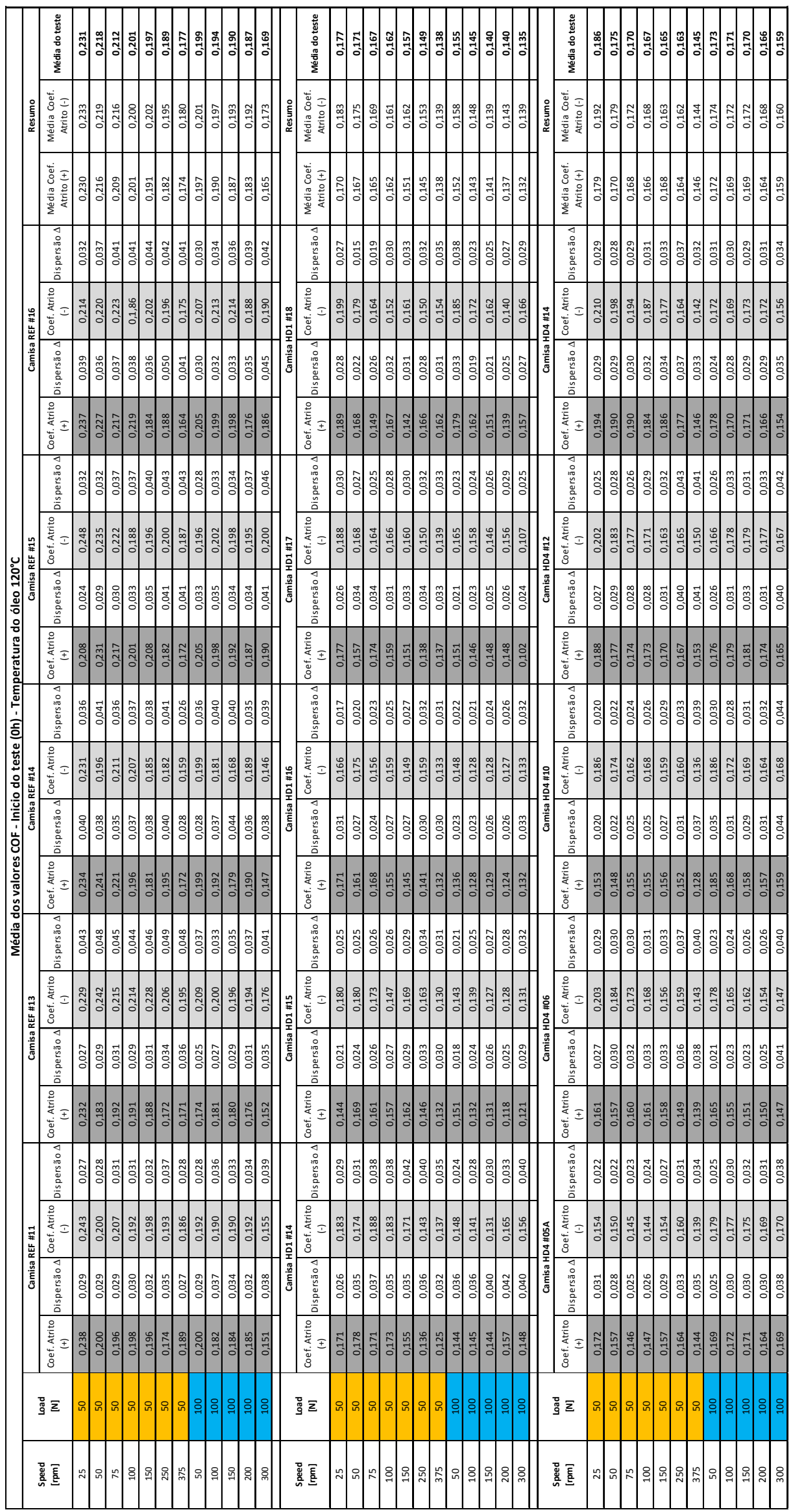




\section{APÊNDICE G - Resumos dos valores de COF a $120^{\circ} \mathrm{C}(2 \mathrm{~h})$}

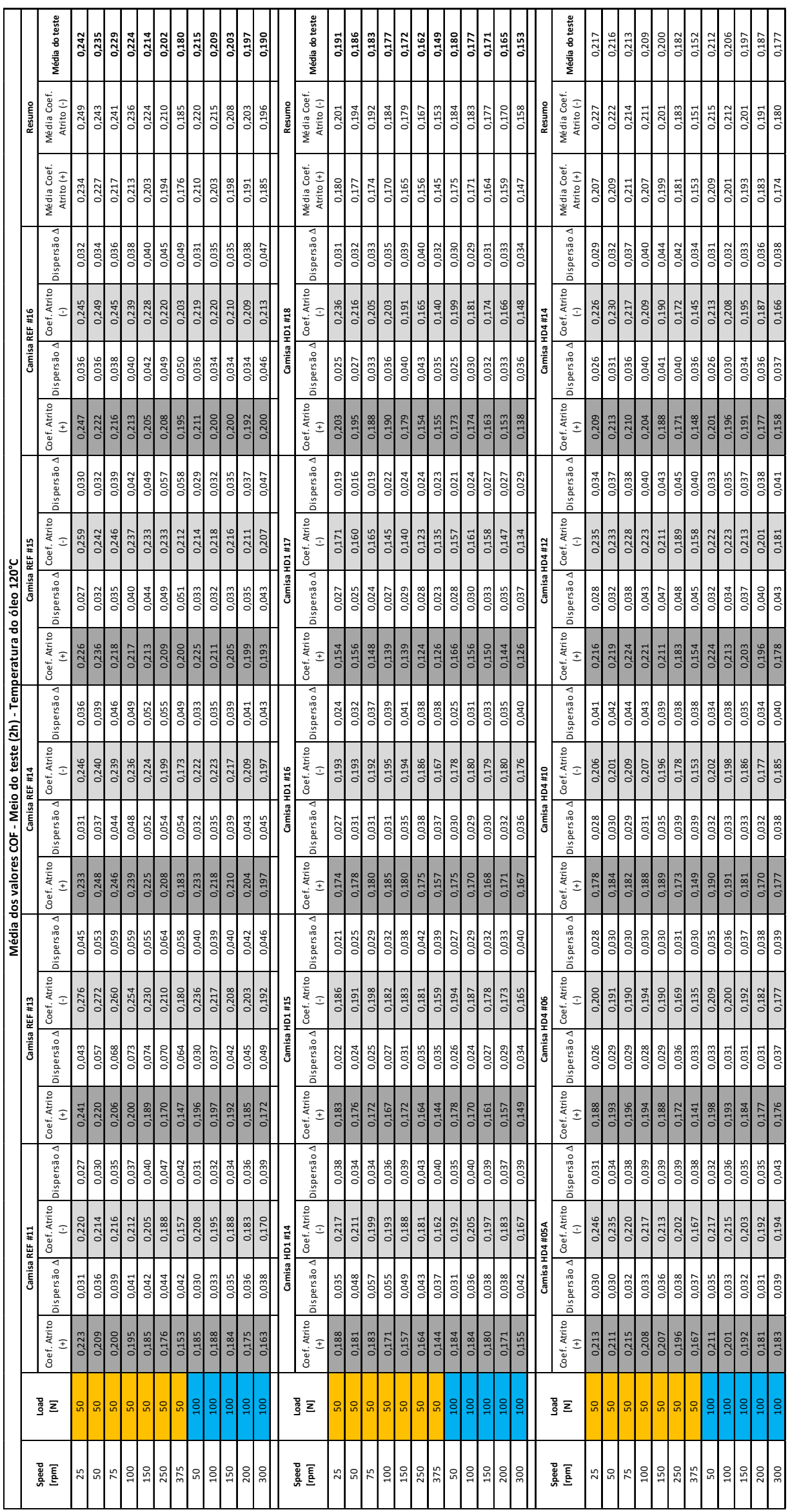




\section{APÊNDICE H - Resumos dos valores de COF a $120^{\circ} \mathrm{C}$ (4h)}

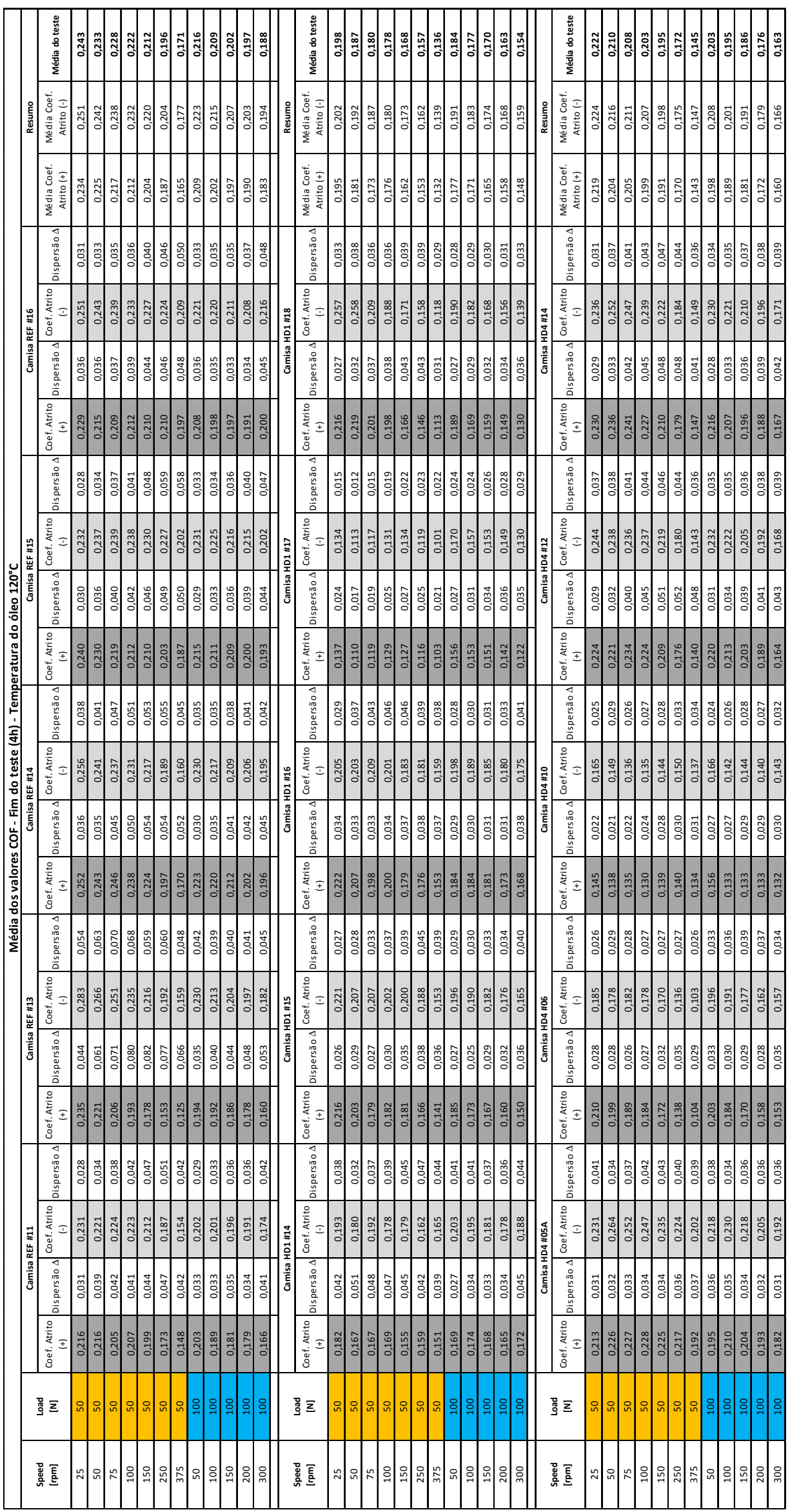




\section{APÊNDICE I - Propriedades físico-química do óleo SAE30}

Dados típicos do óleo mineral utilizado para suportar os testes da bancada recíproca.

\begin{tabular}{|c|c|c|c|c|c|c|c|}
\hline \multirow{2}{*}{ Características } & \multirow{2}{*}{$\begin{array}{c}\text { Método } \\
\text { ASTM }\end{array}$} & \multicolumn{6}{|c|}{ Grau ISO } \\
\hline & & 32 & 46 & 68 & 100 & 150 & 220 \\
\hline Uso do produto & \multicolumn{7}{|c|}{ Óleo para turbinas } \\
\hline Dados do fornecedor & \multicolumn{7}{|c|}{ Chevron Brasil Lubrificantes Ltda. } \\
\hline Descrição do produto & \multicolumn{7}{|c|}{ Óleo mineral altamente refinado (C15 - C50) } \\
\hline Classificação SAE & \multicolumn{7}{|c|}{ SAE 30} \\
\hline Código do produto & & 00700 & 00701 & 00702 & 00706 & 00715 & 01531 \\
\hline Código de PISPQ & & 15118 & 15118 & 15118 & 15118 & 15118 & 15118 \\
\hline Densidade @ $20^{\circ} \mathrm{C}$ & D-4052 & 0,8605 & 0,8659 & 0,8719 & 0,877 & 0,8836 & 0,8885 \\
\hline $\begin{array}{l}\text { Viscosidade Cinemática } \\
\text { cSt @ } 40^{\circ} \mathrm{C} \\
\text { cSt @ } 100^{\circ} \mathrm{C} \\
\end{array}$ & $\begin{array}{l}D-445 \\
D-445\end{array}$ & $\begin{array}{l}30,88 \\
5,40 \\
\end{array}$ & $\begin{array}{l}44,28 \\
6,80 \\
\end{array}$ & $\begin{array}{l}66,18 \\
8,73 \\
\end{array}$ & $\begin{array}{l}95,00 \\
11,00 \\
\end{array}$ & \begin{tabular}{|l|}
139,00 \\
14,12 \\
\end{tabular} & $\begin{array}{l}204,50 \\
17,96 \\
\end{array}$ \\
\hline Índice de Viscosidade & D-2270 & 109 & 109 & 104 & 100 & 99 & 96 \\
\hline Ponto de Fulgor, $\mathrm{COC},{ }^{\circ} \mathrm{C}$ & D-92 & 216 & 236 & 260 & 266 & 270 & 282 \\
\hline Ponto de Fluidez, ${ }^{\circ} \mathrm{C}$ & $D-97$ & -6 & -6 & -3 & -3 & -3 & -3 \\
\hline Neutralização, mg KOH/g & D-974 & 0,09 & 0,1 & 0,09 & 0,12 & 0,08 & 0,06 \\
\hline Emulsão, a $54,4^{\circ} \mathrm{C}$, minutos & D-1401 & 20 & 15 & 20 & 20 & 15 & 20 \\
\hline
\end{tabular}

Os dados acima são apenas valores médios, podendo ocorrer pequenas variações que não afetam o desempenho do produto.

Dados típicos do óleo mineral utilizado para suportar os testes da bancada recíproca a $260^{\circ} \mathrm{C}$.

\begin{tabular}{|l|r|r|r|r|}
\hline \multirow{2}{*}{ Características } & \multicolumn{4}{c|}{ Grau ISO } \\
\cline { 2 - 5 } & \multicolumn{1}{|c|}{$\mathbf{3 2}$} & \multicolumn{1}{c|}{$\mathbf{4 6}$} & \multicolumn{1}{c|}{$\mathbf{6 8}$} & \multicolumn{1}{c|}{100} \\
\hline Código do produto & \multicolumn{1}{|c|}{00700} & 00701 & \multicolumn{1}{c|}{00702} & 00706 \\
\hline $\begin{array}{l}\text { Condutividade témica, } \\
\text { BTU/hr-ft- }{ }^{\circ} \mathrm{F}\end{array}$ & 0,0676 & 0,0671 & 0,0666 & 0,0663 \\
\hline $\begin{array}{l}\text { Calor Específico, } \\
\text { BTY } / \mathrm{lb}-{ }^{\circ} \mathrm{F} \text { ou Calorias } / \mathrm{gm} /{ }^{\circ} \mathrm{C}\end{array}$ & 0,6603 & 0,6579 & 0,6557 & 0,6539 \\
\hline Densidade & 0,7101 & 0,7161 & 0,7221 & 0,7271 \\
\hline
\end{tabular}

Valores calculados com base na carta de informação ChevronTexaco ํํ 442 de 01/06/2004 


\section{REFERÊNCIAS BIBLIOGRÁFICAS}

AKALIN, O.; COBANOGLU, S.; TOYGAR, A.; GUL, O.; KURNAZ, G.; ERGEN, O. $R$. The effects of power cylinder design parameters on lube oil consumption of a heavy duty diesel engine. In: ASME INTERNAL COMBUSTION ENGINE DIVISION 2008 SPRING TECHNICAL CONFERENCE, Apr. 27-30, Chicago, Illinois, USA. Proceedings... Chicago, Illinois: ASME, 2008 (ICES2008-1661).

AMERICAN SOCIETY OF MECHANICAL ENGINEER. Surface Texture (Surface Roughness, Waviness,and lay). ANSI/ASME B46.1-1995.

ANDERSSON, P.; TAMMINEN, J.; SANDSTÖM, E. Piston ring tribology: a literature survey. Espoo 2002. VTT Tiedotteita - Research Noter 2178. Finlândia: Helsinki University of Technology, 2002.

ANDERSSON, P. Measurements on piston ring friction: current trends in tribology. Poland: Institute for Terotechnology - National Research Institute, 2003.

ASSOCIAÇÃO BRASILEIRA DE NORMAS TÉCNICA. Tolerâncias geométricas - Tolerâncias de forma, orientação, posição e batimento - Generalidades símbolos, definições e indicações em desenho: procedimento. Rio de Janeiro: ABNT, May, 1997. (NBR 6409)

ASSOCIAÇÃO BRASILEIRA DE NORMAS TÉCNICA. Tolerâncias gerais Parte 2 Tolerâncias geométricas para elementos sem indicação de tolerância individual: procedimento. Rio de Janeiro: ABNT, Fev. 2001. (NBR ISO 2768-2).

ASSOCIAÇÃO BRASILEIRA DE NORMAS TÉCNICAS. Especificações geométricas do produto (GPS) - Rugosidade: Método do perfil - Termos, definições e parâmetros da rugosidade. Rio de Janeiro; ABNT, Set. 2002. (NBR ISO 4287:2002).

BAIA NETO, A. L.; SANTOS, R. A.; FREIRE Jr., F. L.; CAMRAGO Jr., S.S.; CARIUS, R.; FINGER, F. Relation between mechanical and structural properties of silicon-incorporated hard a-C:H films. Thin Solid Films, v. 293, p. 206-211, 1997

BALAGURA, O.V.; IVANOV, A.I. Optika i Spektrask. (USSR). vol. 1043, n. 62 (Opt. Spectrosc. vol. 616, n. 62), 1987.

BLAXILL, H.; READER, S.; MACKAY, S.; LERCH, B.; RUECKAUF, J. Development of a friction optimized engine. In: SAE INTERNATIONAL CONFRESS, Apr. 20-22, Detroit, Michigan, USA. Proceedings... Detroit, Michigan: SAE, 2009 (SAE2009-01-1052).

BASSHUYSEN, R. van.; SCHÄFER F. Internal Combustion Engines Handbook. SAE International, Warrandale, p. 118-122, 2004. 
BEWILOGUA, K.; BRÄUER, G.; DIETZ, A.,GÄBLER. J.; GOCH, G.; KARPUSCHEWSKI, B.; SZYSZKA, B. Surface technology for automotive engineering. CIRP Annals - Manufacturing Technology - ScienceDirect, v. 58, p. 608-627, 2009. journal homepage: <http: / /ees.elsevier.com/cirp/default.asp>. Acesso em: 5 nov. 2011.

BUNSHAH, R. F. Handbook of Deposition Technologies for Films and Coatings Science - Technology and Applications, $2^{\text {nd }}$ ed., Park Ridge, New Jersey, U.S.A., 1994. cap. 1, Deposition Technologies: An Overview Noyes Publications. p. 27-44.

CASIRAGHI, C.; PIAZZA, F.; FERRARI, A.C.; GRAMBOLE, D.; ROBERTSON, J. Bonding in hydrogenated diamond-like carbon by Raman spectroscopy. Diamond \& Related Materials, v. 14, p. 1098-1102, 2005.

CHARITIDIS, C.A. Nanomechanical and nanotribological properties of carbonobased thin films: A review. J. of refractory Metals and Hard Materials, v. 28, p. 51-70, 2010.

CHEN X., PENG, Z., FU, Z. WU, S., YUE, W. WANG, C. Microstructural, mechanical and tribological properties of tungsten-gradually doped diamond-like carbon films with functionally graded interlayers. J. Surface \& Coating

Technology - Elsevier. Vol. 205, p. 3631-3638, 2011.

CHIAVERINI, V. Aços e ferros fundidos. ABM - Associação Brasileira de Metais, São Paulo, 6ª edição, 1988.

CHOY, K.L. Chemical vapour deposition of coatings, Progress in Materials Science v. 48, p. 57-170, 2003.

DAM, W. V.; COOPER, M. W.; OXORN, K.; RICHARDS, S. Observations from cylinder liner wear studies in heavy duty diesel engines and the evolution towards lower viscosity heavy duty engine lubricants. In: SAE INTERNATIONAL CONGRESS, Apr. 12-14, Detroit, Michigan, USA. Proceedings... Detroit, Michigan: SAE, 2011 (2011-01-1207).

DAMASCENO, J. C.; CAMARGO JR, S. S.; FREIRE JR, F. L., et al. Deposition of Si-DLC Films with high hardness, low stress and high deposition rates. Surface and Coatings Technology. v.133-134, p. 247-252, 2000.

DAMASCENO, J. C.; CAMARGO, S. S.; CREMONA, M. Deposition and Evaluation of DLC-Si Protective Coatings for Polycarbonate Materials. Thin Solid Films, v. 420-421, p. 195-199, 2002.

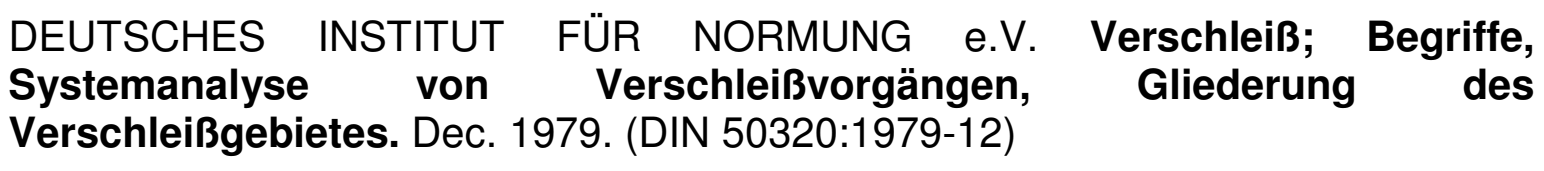

DEUTSCHES INSTITUT FÜR NORMUNG e.V. Standard grey cast iron. Aug. 1997. (DIN EN 1561:1997-08). 
DEUTSCHES INSTITUT FÜR NORMUNG e.V. Soberflächenbeschaffenheit: Tastschnittverfahren Messtechnische eigenschaften von phasenkorreken Filtrern. Sep. 1998. (DIN EN 11562:1998-04).

DEUTSCHES INSTITUT FÜR NORMUNG e.V. GPS - Surface Texture: Profile method. Surfaces having stratified functional properties. Part 1: Filtering and general measurement conditions. Apr. 1998. (DIN EN ISO 13565:1998-1).

DEUTSCHES INSTITUT FÜR NORMUNG e.V. GPS - Surface Texture: Profile method. Surfaces having stratified functional properties. Part 2: Height characterization using the linear material ratio curve. Apr. 1998. (DIN EN ISO 13565:1998-2).

DEUTSCHES INSTITUT FÜR NORMUNG e.V. Manufacturing Processes Chip Removal - Part 13: Honing By Linear Cutting Motion - Classification, Subdivision, Terms And Definitions. Sep. 2003. (DIN EN 8589:2003-13).

DEUTSCHES INSTITUT FÜR NORMUNG e.V. Manufacturing Processes Chip Removal - Part 14: Honing And Super Finishing - Classification, Subdivision, Terms And Definitions. Sep. 2003. (DIN EN 8589:2003-14).

DEUTSCHES INSTITUT FÜR NORMUNG e.V. Standard spheroidal graphite cast irons. Oct. 2005. (DIN EN 1563:2005-10).

DONNET, C.; GRILL, A. Friction Control of Diamond-like carbon coating. Surface and Coatings Technology. v. 94-95, p. 456-462, 1997.

DONNET, C.; FONTAINE, J.; GRILL, A.; LE MOGNE, T. The role of hydrogen on the friction mechanism of diamond-like carbon films. Tribology Letters. vol. 9 no․ 3-4, 2000.

DREES, D.; CELIS, J.P.; ACHANTA, S. Friction of thin coatings on three length scales under recíprocating sliding, Surface and Coatings Technology. v. 188189, p. 511-518, 2004.

ERDEMIR, A. The role of hydrogen in tribological properties of diamond-like carbon films. Surface \& Coatings Technology - ScienceDirect. n. 146, p. 292297, 2001. Disponível em: <www.sciencediredct.com>. Acesso em: 8 jul. 2010

ERNST, P.; BARBEZAT, G. Thermal spray applications in powertrain contribute to the saving of energy and material resources. Surface \& Coating Technology ScienceDirect, n. 202, p. 4428-4431, 2008. Disponível em:

<www.sciencediredct.com>. Acesso em: 28 abr. 2010.

ETZ, E.S.; HURST, W.S.; FELDMAN, W. Correlation of the Raman spectra with thermal conductivity of a set of diamond wafers prepared by chemical vapor deposition. J. Materials Research, v. 16, p 1694, 2001.

FERGURSON, C. Internal combustion engines applied thermo sciences. USA, John Wiley \& Sons, 1985. 
FERRARI, A. C.; ROBERTSON, J. Interpretation of Raman spectra of disordered and amorphous carbon. J. Physical review B. vol. 61, p, 14095-14107, 2000.

FERRARI, A.C.; ROBERTSON, J., Resonant Raman spectroscopy of disordered, amorphous, and diamond-like carbon. J. Physical Review B. vol. 64, p. 0754141-07541-13, 2001.

FERRARI, A. C. Non-destructive characterization of carbon films. Tribology of Diamond-Like Carbon Films: Fundamentals and Applications. Springer, p. 2582, 2008.

FLEX-HONE. Resource guide - Information on tool selection, grit selection, suggested RPM's and more. Brush research manufacturing Co., Inc., 2011. Disponível em:

$<$ http://www.brushresearch.com/pdf/FlexHone_Resource_Guide.pdf>. Acesso em 20 jul. 2012.

FLORES, G. Grundlagen und Anwendungen des Honens. Vulkan-Verlag Essen. Essen, 1992. Disponível em: <www.hs-esslingen.de/static/326/1_Honen.pdf>. Acesso em: 27 jun. 2010.

FONTAINE, J.; DONNET, C.; GRILL, A.; et al. Tribochemistry between Hydrogen and Diamond-like carbon films. Surface \& Coating Technology - ScienceDirect, v. 146-147, p. 286-291, 2001. Disponível em: <www.sciencediredct.com>. Acesso em: 3 out. 2011.

GAHR, K. Z. Microstructure and wear of materials. J. Tribology series 10, Elsevier Science Publishing Company Inc. New York, vol. 10, p. 80-104, 1987.

GANESAN, V. Internal Combustion Engines. USA, McGraw-Hill, Inc., 1995.

GANGOPADHYAY, A. K.; WILLERMET, P. A.; TAMOR, M. A.; VASSEL, W. C. Amorphous hydrogenated carbon films for tribological applications I. Development of moisture insensitive films having reduced compressive stress. Tribology International - Elsevier, v. 30, n. 1, pp. 19-28, Jan. 1997.

Disponível em:

<http://www.sciencedirect.com/science/article/pii/0301679X96000175>.

Acesso em: 26 dez. 2011.

GEHRING GmbH - Advanced honing technology - Laser honing. Disponível em: <http://www.gehring.de/en/technology/laser-honing/>. Acesso em: 20 feb. 2011.

GRILL, A.; PATEL, V.; Tribological properties of diamond-like carbon and related materials, J. Diamond and Related Materials - Elsevier. vol. 2, issues 5-7, p. 597-605, 13 Apr. 1993. Disponível em:

<http://www.sciencedirect.com/science/article/pii/092596359390190D>.

Acesso em: 15 feb. 2012. 
GRILL, A; MEYERSON, B. S. Development and status of diamondlike carbon. In: K. E. Spear and J. P. Dismukes (eds). Synthetic Diamond: Emerging CVD Science and Technology, Wiley, NY, p. 91-141, 1994.

GRILL, A. Tribology od diamond-like carbon and related materials: an updated review. In: $24^{\text {th }}$ International conference on Metallurgical coatings and thin films. J. Surface and Coating Technology - Elsevier. v. 94-95, p. 507, 1997. Disponível em: < http://www.sciencedirect.com/science/article/pii/S0257897297004581>. Acesso em: 11 jul. 2012.

GRILL, A. Plasma-deposited diamondlike carbon and related materials. IBM Journal of Research and Development, v. 43, issues 1-2, p. 147-162, Jan. 1999a. Disponível em:

$<$ http://ieeexplore.ieee.org/xpl/login.jsp?tp=\&arnumber=5389254\&url=http\%3A\%2 F\%2Fieeexplore.ieee.org\%2Fiel5\%2F5288520\%2F5389250\%2F05389254.pdf\%3 Farnumber\%3D5389254>. Acesso em: 24 mai. 2011.

GRILL, A., Diamond-like carbon: State of the Art. J. Diamond and Related Materials, n. 8, p. 428-434, New York, USA, 1999b.

GRUNEIS, A.; SAITO, R.; KIMURA, T.; CANCADO, L.G.; PIMENTA, M.A.; JORIO, A.; SOUZA FILHO, A.G.; DRESSELHAUS, G.; DRESSELHAUS, M.S. Determination of two-dimensional phonon dispersion relation of graphite by Raman spectroscopy. J. Physical Review B, vol. 65, issue 15, p. 155405, 2002. Disponível em: < http://prb.aps.org/abstract/PRB/v65/i15/e155405>. Acesso em: 23 jul. 2012.

GUIBET, J. C.; FAURE, E. Carburants et moteurs. Technologies-ÉnergieEnvironnement, vols. 1 and 2, editions Technip, Paris, 1997.

HEYWOOD, J. B. Internal Combustion Engine Fundamentals. McGraw-H International Editions, 1988, p. 12-14, 15-17, 25-28, 715-719, 729-733

HOLMBERG, K.; MATTHEWS, A. Coatings tribology - Properties, Mechanisms, Techniques and Applications in Surface Engineering. Tribology and interface engineering series, n. 56. P. 249-266, $1^{\text {st }}$ edition, Oxford, UK, 1994.

HUTCHINGS, I.M. Tribology Friction and Wear of Engineering Materials. Edward Arnold, London, Chapter.5, p.86-92, 1992.

JARRATT, M.; STALLARD, J.; RENEVIER, N. M.; TEER, D. G. An improved diamond-like carbon coating with exceptional wear properties. J. Diamond and Related Materials - Elsevier. v. 12, p. 1003-1007, 2003.

JOCSAK, J. et al. The effects of cylinder liner finish on piston ring-pack friction. In: ASME INTERNAL COMBUSTION ENGINE DIVISION 2004 SPRING TECHNICAL CONFERENCE, Oct. 24-27, Long Beach, California, USA. Proceedings... ASME, 2004 (ICEF2004-952). 
JOHNSON, K. L.; SHERCLIFF, H. R. Shakedown of two-dimensional asperities in sliding contact. International J. of Mechanical Science, vol. 34, p. 375-394, 1991.

KESAVAN, S. K.; AZAD, A. M. Conversion of steel mill waste into nanoscale zerovalent iron (nZVI) particles for hydrogen generation via metal-steam reforming. International J. of Hydrogen Energy, n. 33, p. 1232-1242, Feb., 2008. Disponível em: <http://www.elsevier.com/wps/find/homepage.cws_home>. Acesso em: 30 jan. 2011.

KÖHLER, E.; FLIERL, R. Verbrennungsmotoren - Motormechanik, Berechnung und Auslegung des Hubkolbenmotors. 4 ed. Wiesbaden, Vieweg Verlag, 2006.

LEMKE, J. S.; HINRICH-WIHELM; HORST, B.; BRINKMANN, S. Characteristic parameters of the Abbott curve for the integral evaluation of 3D measured cylinder liner surfaces. MTZ worldwide edition, vol. 64, p.34 - 36, May, 2003.

Disponível em:

<http://www.atzonline.com/index.php;sid=f2d9825cdd23255b7342a2f47b297af0/si te $=a 4$ e/lng=en/do=show/id=1685/alloc=3>. Acesso em: 4 nov. 2010.

LEÓN, F. P. Evaluation of Honed Cylinder Bores. CIRP General Assembly, San Sebastián, Spain, 18-24 August 2002, CIRP Annals, vol. 51, Jan., 2002.

Disponível em: < http://www.iiit.kit.edu/publ/cirp2002.pdf>. Acesso em: 23 set. 2011.

LIFSHITZ, Y. Diamond-like Carbon - Present Status. J. Diamond and Related Materials - Elsevier, v. 8, p. 1659-1676, 1999.

LIMA, M. S. F. de.; FAGOIA, F. A. G.; CARVALHO, S. M.; CAMPOS, B. M.; RIVA, R. Tratamentos a laser de ferros fundidos vermiculares. In: 6은 CONGRESSO BRASILEIRO DE ENGENHARIA DE FABRICAÇÃO, 11-15 Abril, Caxias do Sul, RS, Brasil. Anais eletrônicos... Caxias do Sul: ABCM (COF11-0066), 2011. Disponível em:

<http://alvarestech.com/temp/cobef2011/grima.ufsc.br/cobef2011/media/trabalhos/ COF11-0066.pdf>. Acesso em: 21 jun. 2012

LIU, Y.; ERDEMIR, A.; MELETIS, E. I. Influence of environmental parameters on the friction behavior of DLC coatings. In: INTERNATIONAL CONFERENCE ON METALLURGICAL COATINGS AND THIN FILMS, Apr. 21-25, San Diego, California, USA. Proceedings... ICMCTF 1997 (19980402 010). Disponível em:

<http://www.osti.gov/bridge/servlets/purl/634091-

D0K2qQ/webviewable/634091.pdf>. Acesso em: 20 jan, 2012.

LOBO, A. O.; MARTIN, A. A.; ANTUNES, E. F.; TRAVA-AIROLDI, V. J.; CORAT, E. J. Caracterização de materiais carbonosos por espectroscopia Raman. Revista brasileira de aplicações de vácuo, v. 24, n. 2, p. 98-103, 2005

LUSK, D.; CASSERLY, T.; GUPTA, M.; BOINAPALLY, K.; CAO, Y.; RAMAMURTI, R.; DESAI, P. A high density hollow cathode plasma PECVD technique for 
deposition films on the internal surfaces of cylindrical substrates. J. Plasma processes and polymers. Wiley-VHC Verlag GmbH Co. KGaA, Weinheim. Vol. 6, p. S429-S432, 2009.

MAHLE, Metal Leve SA. Manual Técnico para aftermaket. Curso MAHLE Metal Leve - Motores à combustão interna, 2012.

Disponível em:

<http://www.mahle.com/C1256F7900537A47/vwContentByKey/W28HPJTN971ST ULDE/\$FILE/Manual_mahle_brochura\%20-\%2099-164_segunda\%20parte.pdf>. Acesso em: 30 oct. 2012.

MANAV, D.; OZDEMIR, K.; ERPOLAT, S. Effect of design modification of intrabore region on engine block bore distortion. In: SAE INTERNATIONAL CONGRESS, Apr. 13-15, Detroit, Michigan, USA. Proceedings... SAE, 20120 (2010-01-1524). Disponível em: < http://papers.sae.org/2010-01-1524/>. Acesso em: 3 jul. 2011.

MARTINS, J. Motores de Combustão Interna. 2 ed. Porto, Publindústria, 2006

MATTOX, D. M. Handbook of physical vapor deposition (PVD) processing. Society of Vacuum Coaters Albuquerque, NOYES PUBLICATIONS Westwood, New Jersey, EUA, 1998.

MOCELLIN, F. Nova tecnologia: brunimento em ferro fundido. CIMM - Inovação e processos, 07 nov. 2007. Disponível em:

$<$ http://www.cimm.com.br/portal/noticia/exibir_noticia/2304-nova-tecnologiabrunimento-em-ferro-fundido-vermicular>. Acesso em: 11/04/2010.

MORGENSTERN, R.; KIESSLING, W.; REICHSTEIN S. Reduced friction losses and wear by DLC coating of piston pins. In: ASME INTERNAL COMBUSTION ENGINE DIVISION 2008 FALL TECHNICAL CONFERENCE, Apr. 27-30, Chicago, Illinois, USA. Proceedings... Chicago, Illinois: ASME, 2008 (ICES20081650).

NAKAYAMA, K.; TAMAKI, S.; MIKI, H.; TAKIGUCHI, M. The Effect of Crankshaft Offset on Piston Friction Force in a Gasoline Engine. In: SAE INTERNATIONAL CONGRESS - CI and SI POWER CYLINDER SYSTEMS (PART A and B), Mar. 69, Detroit, USA. Proceedings... Detroit, MI, USA: SAE, 2000 (2000-01-0922).

NEMANICH, R.J.; SOLIN, S.A. First- and second-order Raman scattering from finite-size crystals of graphite. J. Physical Review B, vol. 20, p. 392-401, 1979.

Disponível em: < http://prb.aps.org/abstract/PRB/v20/i2/p392_1>. Acesso em: 20 set. 2011.

OLIVER, W. C.; PHARR, G. M. An improved technique for determining hardness and elastic modulus using load and displacement sensing indentation experiments. J. Material Research Society, vol. 7, n. 6, p. 1564-1580, Jun., 1992. 
ÖNER, C.; HAZAR, H.; NURSOY, M. Surface properties of CrN coated engine cylinders. J. Materials and Design, vol. 30, p. 914-920, 16, May, 2009. Disponível em: <www.elsevier.com/locate/matdes>. Acesso em: 30 mar. 2010.

PAWLUS, P.; CIESLAK, T.; MATHIA, T. The study of cylinder plateau honing process. J. of Materials Processing Technology - Elsevier Science B. V., Amsterdam, vol. 209, n. 20, p. 6078-6086, 2009

PAWLUS, P.; MICHALSKI, J. Simulation of cylinder "zero-wear" process. J. Wear - Elsevier, v. 266, issues 1-2, p. 208-213, Jan., 2009

PAUSCHITZ, A.; SCHALKO, J.; KOCH, T.; EISENMENGER-SITTNER, C.; KVASNICA, S.; MANISH, R. Nano indentation and AFM studies of PECVD DLC and reactively sputtered Ti containing carbon films. J. Material Science, Indian Academy of Sciences, vol. 26, n. 6, p. 585-591, Oct., 2003

PERINI, R. $O$ uso da difração de raios $x$ para determinação da tensão residual induzida pelo processo de roleteamento em uma camisa de cilindro de motor diesel. Tese (Mestrado na área de tecnologia nuclear), Instituto de pesquisas energéticas e nucleares, São Paulo, 2008.

PISCHINGER, S. Verbrennungskraftmaschinen I. 26 ed. Aachen: Lehrstuhl für Verbrennungskraftmaschinen, 2007

PISCHINGER, S. Potenziale zur Reibleistungsreduktion der Kolbengruppe. In: ATZ/MTZ - Konferenz - Reibungsminimierung. Nürtinger Honsymposium, 26, nov. 2009. Disponível em: < http://www.atzonline.de/Events/Vortrag/399.html>. Acesso em: 5 jul. 2011.

PRIEST, M.; TAYLOR, C.M. Automobile engine tribology - approaching the surface. J. Wear - Elsevier, vol. 241, p. 193 -203, 2000.

RABUTÉ, R.; TIAN, T. Challenges involved in piston top rings designs for modern Sl engines. J. Engineering Gas Turbines Power, vol. 123, p. 448, 2001.

REJOWSKI E.; MORDENTE P.; PILLIS M.; CASSERLY T. Application of DLC coating in cylinder liners for friction reduction. In: SAE WORLD CONGRESS, April 24-26, Detroit, Michigan, USA. Proceedings... Detroit: SAE International, 2012 (SAE 2004-01-0604).

RICHARDSON, D. E. Review of Power Cylinder Friction for Diesel Engines. J. of Engineer for Gas Turbines and Power, vol.122, Oct., 2000. ROBERTSON, J. Properties of diamond-like carbon. J. Surface and Coatings Technology - Elsevier, vol. 50, issue 3, p. 185-203, 6 Feb. 1992. Disponível em: $<$ http://www.sciencedirect.com/science/article/pii/025789729290001Q>. Acesso em: 7 set. 2011.

ROBERTSON, J. Diamond-like amorphous carbon. J. Material Science and Engineering - Elsevier. Vol. 37, issues 4-6, p. 129-281, 24 May 2002. Disponível 
em: < http://carbon.utsi.edu/downloads/JRobertson_MSER.pdf>. Acesso em: 5 ago. 2010.

ROBERTSON, J., Improving the Properties of Diamond-like Carbon. J. Diamond and Related Materials, v. 12, p. 79-84, 2003

RONKKAINEN, H. Tribological properties of hydrogenated and hydrogen-free diamond-like carbon coatings. Dissertation for the degree of Doctor of Science in Technology (Helsinki University of Technology - Espoo, Finland), $15^{\text {th }}$ of June, 2001. Disponível em: <http://www.vtt.fi/inf/pdf/publications/2001/P434.pdf>. Acesso em: 08/07/2012.

RUBIM, C. Proconve P7 diminui níveis de emissões de motores a diesel. Revista e Portal Meio Filtrante. Edição n. 55, Março/Abril, 2012. Disponível em: http://www.meiofiltrante.com.br/materias.asp?action=detalhe\&id=772. Acesso em 08/08/2012.

SAITO, R.; JORIO, A.; SOUZA-FILHO, A.G.; DRESSELHAUS, G.; DRESSELHAUS, M.S.; PIMENTA, M.A. Probing phonon dispersion relations of graphite by double resonance Raman scattering. J. Physical Review Letters, v. 88, n. 027401, p. 1-4, 2002.

SATO, O.; TAKIGUCHI, M.; TAKAYUKI, A.; SEKI, Y.; FUJIMURA, K.; TATEISHI, Y. Improvement of Piston Lubrication in a Diesel Engine by Means of Cylinder Surface Roughness. In: SAE INTERNATIONAL CONGRESS, March 8-11, Detroit, USA. Proceedings... Detroit: SAE International, 2004 (SAE 2004-01-0604).

SCHARF, T.W.; SINGER, I.L. Thickness of diamond-like carbon coatings quantified with Raman spectroscopy. J. Thin Solid Films, v. 440. p. 138-144, 2003.

SOUSA, A. R. de. Novos métodos de inspeção da qualidade em cilindros de motores. Artigo Máquinas e Metais, Out. 2006. Disponível em: $<$ http://www.photonita.com.br/downloads/Artigo\%20Máquinas\%20e\%20metais.pdf >. Acesso em 11/04/2010.

TABENKIN, A. Surface finishing measurement basics, quality. vol. 43, p. $20-$ 21, Sep. 2004. Disponível em: < www.qualitymag.com>. Acesso em: 2 jan. 2010.

TAYLOR, C.M., Automobile engine tribology - design for considerations efficiency and durability, J. Wear - Elsevier, vol. 221, p. 1-8, 1998.

THOMSEM, C.; REICH, S. Double resonant Raman scattering in graphite. J. Physical Review Letters, v. 85 n. 24, 11 Dec. 2000. Disponível em: < http://www.szfki.hu/ kamaras/nanoseminar/KurtiJeno/PRL_Thomsen_85_p5214_ 1.pdf >. Acesso em 20 dec. 2011.

TOMANIK, E. Liner Honing Quality Main Characteristics. SAE INTERNATIONAL CONGRESS, April 13-16, Detroit, USA. Proceedings... Detroit: SAE International, 1992 (SAE921453E). 
TOMANIK, E. Piston Ring Conformability in a Distorted Bore. In: SAE INTERNATIONAL CONGRESS, March 9-12, Detroit, USA. Proceedings... Detroit: SAE International, 1996 (SAE960356).

TOMANIK, E. Modelamento do desgaste por deslizamento em anéis de pistão de motores de combustão interna. Tese (Doutorado em Engenharia Mecânica), Escola Politécnica da USP, São Paulo, 2000.

TOMANIK, E., Modelling of the asperity contact area on actual 3D surfaces. In: SAE INTERNATIONAL CONGRESS, April 20-22, Detroit, USA. Proceedings... Detroit: SAE International, 2005 (SAE2005-01-1864).

TOMANIK, E.; FERRARESE, A. Low friction ring pack for gasoline engine. In: ASME INTERNAL COMBUSTION ENGINE DIVISION 2006 FALL TECHNICAL CONFERENCE, November 5-8, Sacramento, USA. Proceedings... Sacramento, USA: ASME,2006 (ICEF2006-1566).

TOMANIK, E. Friction and wear bench tests of different engine liner surface finishes. J. Tribology International - Elsevier, v. 41, p. 1032-1038, 11 Nov. 2008.

TRUHAN J.; QU J.; BLAU P. A rig test to measure friction and wear of heavy duty diesel engine piston rings and cylinder liners using realistic lubricants. $\mathbf{J}$. Tribology International - Elsevier, v. 38, p. 211-218, 2005. Disponível em: < http://www.ornl.gov/ webworks/cppr/y2005/pres/117987.pdf>. Acesso em: 3 jan. 2012.

UEHARA, S. Overview of the New Surface Finishing for SI Bores. In: SAE INTERNATIONAL CONGRESS, April 13-15, Detroit, USA. Proceedings... Detroit: SAE International, 2007 (SAE2007-01-2823).

VEREIN DEUTSCHER GIESSEREIFACHLEUTE. Gusseisen mit Vermiculargraphit. VDG-MERKBLATT W50, Mar. 2003.

VEREIN DEUTSCHER INGENIEURE. Carbon films - Basic knowledge, film types and properties. VDI 2840, Nov. 2005.

VERCAMMEN, K.; HAEFKE, H.; GERBIG, Y.; VAN HULSEL, A.; PFLÜGER, E.; MENEVE, J. A comparative study of state-of-the-art diamond-like carbon films. J. Surface and Coatings Technology - Elsevier. v.133-134, p. 466-472, 2000.

VICENTE, G. C. M. CARATERIZAÇÃO DE FILMES DLC COM POTENCIAL DE UTILIZAÇÃO EM MOTORES DE COMBUSTÃO INTERNA. Dissertação de mestrado. Universidade Federal do Paraná, 2005

YASUDA, Y.; KANO, M.; MABUCHI, Y.; ABOU, S. Research on diamond-like carbon coatings for low-friction valve lifters. In: SAE INTERNATIONAL CONGRESS, April 5-7, Detroit, USA. Proceedings... Detroit: SAE International, 2003 (SAE2003-01-1101). 